\author{
FFCLRP - DEPARTAMENTO DE PSICOLOGIA E EDUCAÇÃO \\ PROGRAMA DE PÓS-GRADUAÇÃO EM PSICOLOGIA
}

\title{
Experiência e luta pela terra: o assentamento Sepé Tiaraju e o MST.
}

Gislayne Cristina Figueiredo Vasquez

Orientador: Prof. Dr. José Marcelino de Rezende Pinto

Tese de Doutorado apresentada ao Programa de PósGraduação em Psicologia, do Departamento de Psicologia e Educação da FFCLRP-USP, como parte dos requisitos para obtenção do título de Doutor em Psicologia.

\section{RIBEIRÃO PRETO - SP}




\section{FICHA CATALOGRÁFICA}

Figueiredo, Gislayne Cristina

Experiência e luta pela terra: o assentamento Sepé Tiaraju e o MST. Ribeirão Preto, 2009.

397 p. : il.; $30 \mathrm{~cm}$

Tese, apresentada à Faculdade de Filosofia, Ciências e Letras de Ribeirão Preto / USP - Dep. de Psicologia e Educação.

Orientador: Pinto, José Marcelino de Rezende

1. Psicologia Social. 2. Teoria Crítica. 3. MST. 
FIGUEIREDO, G.C. Experiência e luta pela terra: o assentamento Sepé Tiaraju e o MST. Tese apresentada à Faculdade de Filosofia, Ciências e Letras da Universidade de São Paulo para obtenção do título de Doutor em Psicologia.

Aprovado em:

Banca Examinadora

Prof. Dr. Instituição:

Julgamento: Assinatura:

Prof. Dr. Instituição:

Julgamento: Assinatura:

Prof. Dr. Instituição:

Julgamento: Assinatura:

Prof. Dr. Instituição:

Julgamento: Assinatura: 

A Alberto, meu companheiro de caminhada, dedico esta tese. 


\section{Agradecimentos}

Pois nenhum nascer do sol, mesmo nas montanhas, é pomposo, triunfal, senhoril; pelo contrário, cada um ocorre de forma tênue e tímida como a esperança de que as coisas ainda possam melhorar, e é precisamente nesse pouco lustre da mais possante das luzes que resiste a imponência comovente.

\section{Theodor Wiesegrund Adorno}

O presente trabalho contou com o apoio de várias pessoas, sem o qual esta pesquisa não teria ocorrido. Gostaria de agradecer algumas delas:

O primeiro deles é o meu orientador, prof. Dr. José Marcelino de Rezende Pinto que, mais que orientador, é um companheiro questionador e desafiador do pensamento;

Às companheiras do GEG - Grupo de Estudos em Gestão, cujo apoio ao mesmo tempo próximo e distante - em função da minha distância física - foi essencial para ajustar a tônica deste trabalho;

À minha família, meus pais Luzia e Amarildo, minhas irmãs Gisely e Graziele, que souberam compreender a ausência em diversos momentos, principalmente no período da realização do trabalho de campo e da redação da presente tese;

Ao meu companheiro Alberto, co-participante de todos os momentos desta pesquisa, que contribuiu não só com a compreensão e o suporte em ocasiões mais tensas, mas através de reflexões e de opiniões teóricas, o que também ajudou a enriquecer intelectualmente todo o trabalho; 
À minha sogra Isabel, pela disponibilidade e prontidão com que realizou as traduções;

À Fundação ITESP, que me liberou no início do presente trabalho, possibilitando a sua realização. Aos profissionais dessa instituição com quem tive a satisfação de trabalhar e apreender o como é ser técnico estatal em um assentamento, relembrados neste momento na pessoa de Antônio Carlos Bastos de Mattos (Magu), que também realizou a revisão desta tese;

Aos técnicos estatais que trabalham com a reforma agrária, em especial àqueles que exerceram ou exercem suas atividades no assentamento Sepé Tiaraju, pelo seu comprometimento e seu desejo de contribuir com a construção de um mundo mais justo;

Para finalizar, agradeço aos assentados, aos militantes e à liderança do MST, que abriram suas vidas e as suas reuniões, por vezes em algumas situações tensas e delicadas. Essa disponibilidade e transparência é que permitiu que esta pesquisa ocorresse. Independentemente de que o presente ainda esteja distante dos sonhos almejados, são inegáveis as grandes transformações na vida dos sujeitos que participaram dessa pesquisa, bem como a contribuição para o avanço da reforma agrária no Brasil. 
De primeiro, eu fazia e mexia, e pensar não pensava. Não possuía os prazos. Vivi puxando difícil de difícil, peixe vivo no moquém: quem mói no aspr'o, não fantasêia. Mas, agora, feita a folga que me vem, e sem pequenos desassossegos, estou de range rede. E me inventei neste gosto, de especular idéia.

\section{Guimarães Rosa}




\section{Resumo}

Figueiredo, G.C. Experiência e luta pela terra: o assentamento Sepé Tiaraju e o MST. 2009. 397f. Tese (Doutorado) - Faculdade de Filosofia, Ciências e Letras -USP, Ribeirão Preto, 2009.

A questão agrária acompanha a história do país, marca a base da organização da sociedade brasileira e permanece distante de ser resolvida. Tendo como pano de fundo essa questão, vários movimentos sociais surgiram ao longo da história, inclusive aquele que é considerado hoje o mais importante e vigoroso movimento social que luta pela transformação da sociedade: o Movimento dos Trabalhadores Rurais Sem-Terra (MST). Neste trabalho, pretendemos observar as relações que se estabelecem dentro do movimento social, em sua atuação concreta em um assentamento de reforma agrária, analisando os aspectos que contribuem e os que atrapalham o desenvolvimento de práticas emancipatórias e a construção de uma nova sociedade, utilizando para isso a psicologia social de T.W. Adorno. Como metodologia de pesquisa, optamos por uma abordagem qualitativa, um estudo de caso. Os dados indicam que frente à totalidade reinante nesta sociedade, o MST se constitui em uma possibilidade de que os indivíduos tenham uma experiência (Erfahrung), ou seja, que se coloquem de uma maneira reflexiva frente ao mundo administrado, que tenham uma possibilidade de desenvolvimento do pensamento não tutelado e questionador, ao mesmo tempo em que criam um conteúdo coletivo e um significado partilhado para suas ações. Por outro lado, com a entrada da lógica da mercadoria e do princípio do equivalente no assentamento, a vivência (Erlebnis) tende a tomar o lugar da experiência (Erfahrung), e os indivíduos tendem a voltar a se adaptar ao mundo administrado, o que causa uma série de rompimentos e desencontros. Isso, somado ao ingresso dos agentes estatais no assentamento, faz com que o MST passe a ter dificuldade de manter sua influência junto aos assentados, o que pode levá-lo a assumir uma postura que incentiva a adesão não refletida aos seus princípios e, portanto, remete ao pensamento em bloco, à mentalidade do ticket. Finalizamos salientando que para o MST continuar contribuindo para a emancipação dos sujeitos no assentamento, deve atentar para a importância da autodeterminação e da liberdade dos indivíduos, problematizando o já dado, explicitando as contradições e fomentando a construção de espaços coletivos que contribuam com o esclarecimento, com a autonomia.

Palavras-chave: psicologia social, movimentos sociais no campo, MST, Teoria Crítica, T.W. Adorno. 


\begin{abstract}
Figueiredo, G.C. Experience and struggle for land: the Sepé Tiaraju settlement and the MST (Landless Rural Workers’ Movement). 2009. 397f. Tese (Doutorado) - Faculdade de Filosofia, Ciências e Letras -USP, Ribeirão Preto, 2009.

The "property of the land" question is a permanent issue in the history of the country. It characterizes the basis of the organization of the Brazilian society, and remains as an issue far from being solved. Having this question as a background, several social movements have emerged. Among them, there is one which today is considered the most important and vigorous social movement struggling for a change in society; that is the Landless Rural Workers' Movement (Movimento dos Trabalhadores Rurais Sem-Terra - MST). This study attempts to observe the relations that are established within the social movement, in its concrete action in a land reform settlement. It will also analyze the different aspects that contribute or hinder the development of their emancipation and the construction of a new society. This study is based on the social psychology theories of Theodor Wiesengrund Adorno. As a methodology of research, a qualitative approach and case study were used. All informations, gathered through interviews and practical observation, indicate that in relation to the reigning totality in this society, the MST has become a possibility in which the individuals may have a experience (Erfahrung). This is to say, that these individuals assumed a reflective position in relation to the administered world, and that they had the possibility of developing their own thinking and questioning. At the same time, they created a collective content and a shared meaning for their activities. On the other hand, with the upcoming of the logic of merchandise and the equivalent principle in the settlement, the apprehension of reality (Erlebnis) tends to take the place of experience (Erfahrung) and the individuals tend to go back and adapt themselves to the administered world. This fact causes a series of misunderstanding and ruptures. In addition, the participation of government representatives in this new reality of the settlement, causes problems to the MST. The Movement has difficulties in keeping its influence on the settler. Such a situation may take the MST to assume a position which leads to non-reflective actions not in agreement with its principles, and therefore leads to mass thinking, the socalled ballot mentality. To finish up, the study emphasizes that the MST should continue to contribute towards the emancipation of the individual in the settlement; it should ponder the importance of autodetermination and freedom, pointing out the real cause of problems; it should explain all contradictions; and it should motivate the construction of collective spaces which will contribute to enlightenment, and lead to more autonomy.
\end{abstract}

Key words: social movements in rural areas, MST, social psychology, Critical Theories, Theodor Wiesengrund Adorno. 


\section{Lista de Siglas}

ANCA - Associação Nacional de Cooperação Agrícola

APP - Área de Preservação Permanente

ATER - Assistência Técnica e Extensão Rural

CCA - Cooperativa Central de Reforma Agrária de São Paulo

CEB - Comunidade Eclesial de Base, ligada à CPT

CONAB - Companhia Nacional de Abastecimento

CONCRAB - Confederação das Cooperativas de Reforma Agrária do Brasil

CONTAG - Confederação Nacional dos Trabalhadores na Agricultura

CPA - Cooperativa de Produção Agropecuária

CPS - Cooperativa de Prestação de Serviços

CPFL - Companhia Paulista de Força e Luz

CPT - Comissão Pastoral da Terra

CUT - Central Única dos Trabalhadores

DECA - Declaração Cadastral do Produtor

EESC-USP - Escola de Engenharia de São Carlos da Universidade de São Paulo

EMBRAPA - Empresa Brasileira de Pesquisa Agropecuária

FEB-UNESP - Faculdade de Engenharia de Bauru da Universidade Estadual Paulista Júlio de Mesquita Filho

FEPAF - Fundação de Estudos e Pesquisas Agrícolas e Florestais

FETAESP - Federação dos Trabalhadores na Agricultura do Estado de São Paulo 
HABIS - Grupo de Pesquisa em Habitação e Sustentabilidade, formado por integrantes ligados à EESC-USP e à FEB-UNESP

INCRA - Instituto Nacional de Colonização e Reforma Agrária

MDA - Ministério do Desenvolvimento Agrário

MDS - Ministério do Desenvolvimento Social

MMA - Ministério do Meio Ambiente

MST - Movimentos dos Trabalhadores Rurais Sem Terra

PAA- Programa de Aquisição de Alimentos da CONAB

PCB - Partido Comunista do Brasil

PCC - Primeiro Comando da Capital

PDS - Projeto de Desenvolvimento Sustentável

PMDB - Partido do Movimento Democrático Brasileiro

PT - Partido dos Trabalhadores

PRONAF - Programa Nacional de Fortalecimento da Agricultura Familiar

SIPRA - Sistema de Informações de Projetos de Reforma Agrária

TAC - Termo de Ajustamento de Conduta 


\section{Sumário}

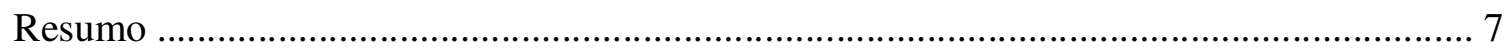

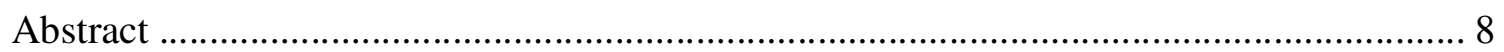

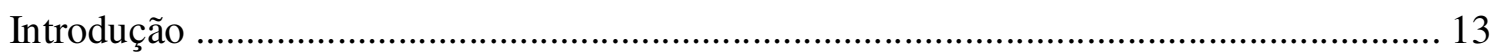

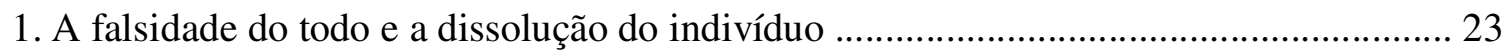

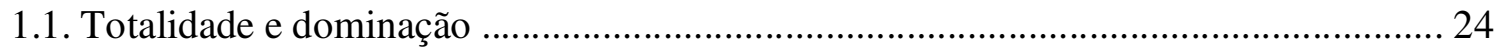

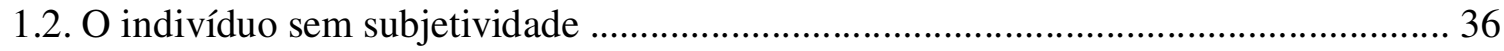

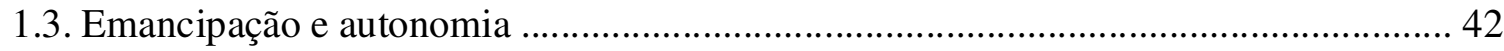

2. Sobre a participação dos indivíduos nos grupos ....................................................... 50

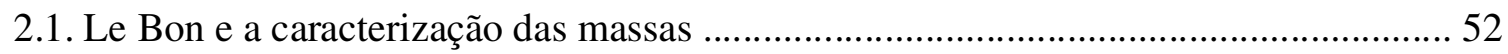

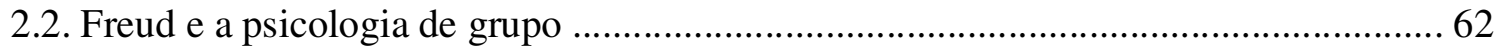

2.3. Ortega y Gasset e a rebelião das massas ...................................................................... 71

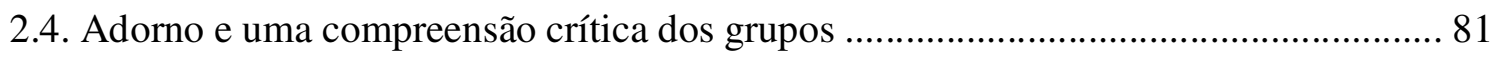

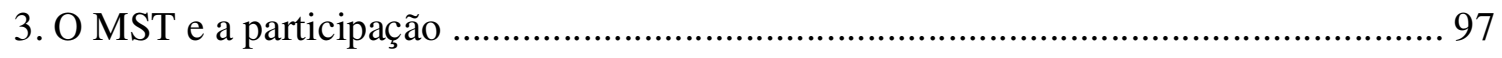

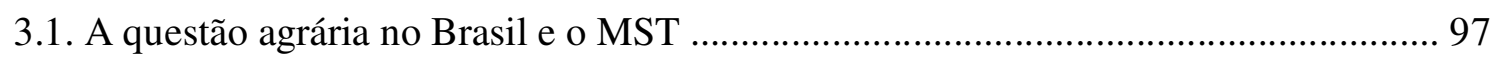

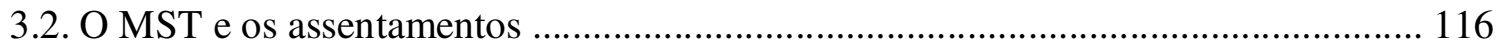

3.3. A organização do assentamento nos documentos do MST ....................................... 132 


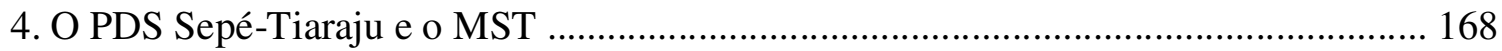

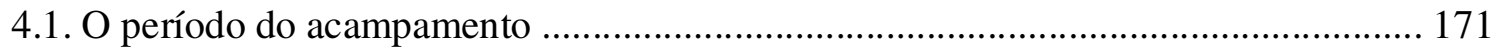

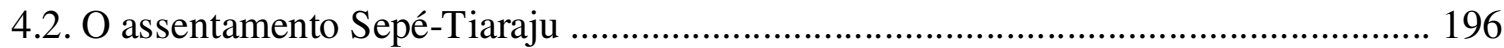

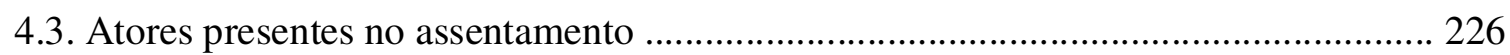

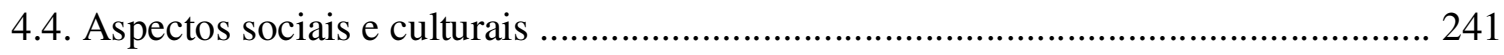

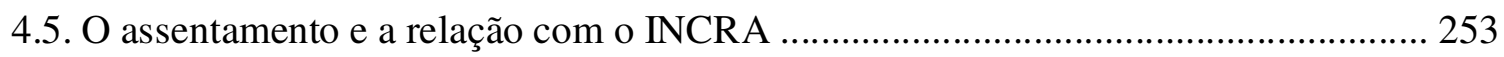

4.6. A relação entre a liderança local do MST e os assentados ....................................... 271

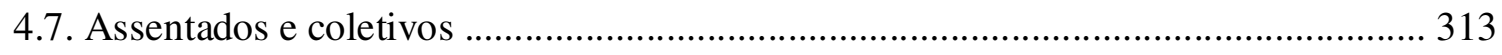

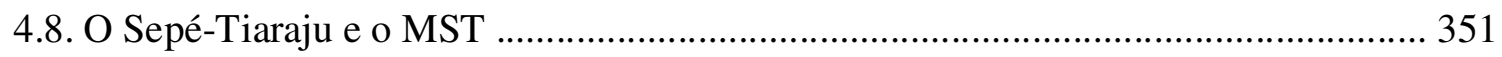

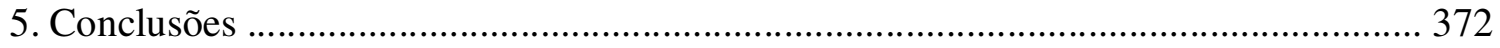

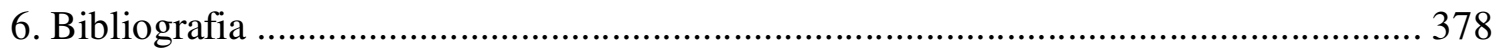

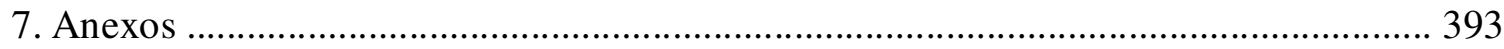




\section{Introdução}

Assim como um planeta gira em torno de um corpo central enquanto roda em torno de seu próprio eixo, assim também o indivíduo humano participa do curso do desenvolvimento da humanidade, ao mesmo tempo que persegue o seu próprio caminho na vida.

Sigmund Freud

As inquietações e questionamentos que levaram à realização desta pesquisa surgiram após o final do mestrado, quando esta pesquisadora foi trabalhar, na condição de funcionária pública, em um assentamento da reforma agrária criado sob a liderança do MST. Tratava-se de um trabalho dos sonhos, idealizado para uma psicóloga recémformada, de esquerda, que então poderia usar seus conhecimentos acadêmicos para contribuir com a construção de um mundo melhor.

As visitas em assentamentos e acampamentos e o apoio ao MST na época da graduação nos traziam notícias de "verdadeiras áreas liberadas" (STÉDILE; FERNANDES, 1999, p. 163), dos assentamentos como sendo uma pequena amostra do mundo que aqueles que sonham com uma nova sociedade, mais igualitária e justa, desejam construir.

Nos assentamentos, esperávamos encontrar um grupo de pessoas em processo de conscientização, os indivíduos se formando de maneira dialética, aprendendo-ensinando durante os processos de participação política e de tomada de decisão, o trabalho coletivo, a 
propriedade conjunta da terra e dos meios de produção, o respeito e a igualdade nas relações mútuas, e os indivíduos alcançando um novo nível de consciência a respeito de si e das relações sociais.

Com a entrada nos assentamentos, podíamos perceber, num contato inicial, que a mudança na vida daquelas pessoas era patente, com muitas delas deixando a vida de mendicância, lutando por seus direitos e participando ativamente de discussões e outras atividades políticas, enfim, como dizem Caldart e Kolling (1997), os sujeitos efetivamente tiravam os olhos do chão e passavam a olhar os outros de frente, denotando que houve uma mudança na forma com que eles encaravam a vida e a si mesmos, mudança essa proporcionada pela participação no MST. Cabe observar que essa mudança nos indivíduos, com o "avanço no nível de consciência" e a "construção de um novo homem e uma nova mulher" (ANCA, 2002, p.5), com a formação de um novo sujeito coletivo e de uma nova identidade coletiva, é um dos objetivos do Movimento.

Por outro lado, notávamos no assentamento a presença de muitos conflitos entre esses assentados e as lideranças do MST. Os assentados reportavam "a culpa" dos conflitos a uma postura autoritária da liderança, e estes, a uma postura individualista da base. Os grupos coletivos inicialmente criados se fragmentavam, e a solidariedade e união existentes no início do assentamento se perdiam. Os assentados passavam a não participar das instâncias coletivas de tomada de decisão, e já não trabalhavam em conjunto.

Essa fragmentação e esse "recuo na consciência" (CONCRAB, 2004, p. 40), bem como a reprodução de relações assimétricas, são identificados tanto pelos teóricos que estudam o movimento social, quanto pelos próprios integrantes do Movimento, conforme podemos constatar em seus documentos oficiais. 
Ainda que já seja considerável a bibliografia que pontua a existência de dificuldades nas relações e interações construídas dentro dos assentamentos, como afirma Caume (2002), essas dificuldades são apenas constatadas, sem maiores explicações quanto a suas origens e seus mecanismos. Outrossim, a fragmentação pós-assentamento é vista como anomia, como algo negativo e incomum, um desvio da comunidade que o assentamento certamente seria se não fossem as dificuldades trazidas pelo individualismo/ autoritarismo.

No entanto, o que se pode constatar é que tal fragmentação da união existente no acampamento, depois que o grupo se torna assentado, é muito mais comum do que querem enxergar parte dos estudiosos do Movimento. Dados (ainda que criticados) do levantamento quantitativo feito por Spavorek (2003), que abrangeu todos os assentamentos no território brasileiro com mais de um ano de implantação, indicam que, à exceção da região sul, a organização dos assentados em cooperativas é ínfima, apontando a dificuldade dos assentados em comporem coletivos.

Cada liderança, de cada novo assentamento, tem consigo a expectativa (e a fantasia) de que este assentamento "vai ser diferente", que vão conseguir construir uma experiência sem conflitos e sem fragmentações posteriores. Já saem de início negando (no sentido psicológico mesmo) a realidade, com uma esperança que desafia o racional e as experiências que eles mesmos vivenciaram, e que, portanto, vai ser frustrada.

Por outro lado, essa fragmentação e os conflitos presentes no assentamento são utilizados por ideólogos da direita como justificativa do insucesso do movimento social, e interpretado como decorrência ora do "autoritarismo" da liderança, que utilizaria métodos militaristas e altamente hierarquizados, ora dos próprios assentados, que são caracterizados como "turba, desvalidos, bandidos, violentos, agressivos, etc.." (REVISTA VEJA, 28 de janeiro de 2009, p. 46 a 50). Esse pensamento conservador classifica o próprio movimento 
social como anomia, responsabilizando-o, bem como aos seus participantes, pelas mazelas às quais eles reagem.

Assim, considerando tanto a importância da questão agrária no Brasil, do próprio MST, quanto o fato de que vários autores colocam os movimentos sociais como uma possibilidade de constituição/reconstituição do sujeito de forma autônoma, bem como de superação da reificação dada por essa sociedade, começamos a nos questionar em que momentos essa interação entre liderança - como porta-voz do movimento social - e sua base era contraditória, e qual a contribuição das partes para o estabelecimento dessas relações.

Atualmente, muitos autores versam sobre a importância dos movimentos sociais e organizações na mobilização da sociedade, na formação e conscientização dos indivíduos que neles participam, e na transformação social que eles podem acarretar, bem como algumas características de seu funcionamento interno. No entanto, como pontuamos acima, poucos estudos enfocam as relações internas a esses movimentos, ou seja, as relações entre os indivíduos participantes do movimento social, e entre estes e o movimento, a influência dos sujeitos na construção dessas relações; bem como os elementos facilitadores e dificultadores dessas interações e o efeito das mesmas sobre os participantes dos movimentos.

Considerando que o assentamento de agricultores é um espaço onde os indivíduos participaram de forma emblemática da luta pela terra e por transformação nas condições sociais, luta na qual os assentados tomaram parte com bastante intensidade do movimento social, que serviu de momento de aprendizagem de relações mais solidárias e democráticas, esse se constitui um espaço privilegiado para estudar como se dão as relações estabelecidas entre indivíduos participantes de um movimento social cujo objetivo é emancipar o homem e transformar a sociedade. 
Assim, este trabalho tem por objetivo estudar as relações que se estabelecem em um movimento de luta pela terra, em sua atuação concreta em um assentamento da reforma agrária, observando os fatores que facilitam e os que dificultam a implantação de práticas solidárias, democráticas e autônomas, tendo por base os pressupostos teóricos da Escola de Frankfurt e, mais precisamente, a Psicologia Social de T.W. Adorno. A opção por este referencial teórico se deve à articulação feita pelo referido autor, em suas análises da realidade social, dos aspectos objetivos e dos subjetivos, a partir de uma leitura que leva em consideração não só uma perspectiva materialista-dialética da história, como também a dinâmica psíquica dos sujeitos envolvidos, partindo de uma leitura psicanalítica do funcionamento subjetivo dos indivíduos.

O desafio de compreender o movimento social e sua contribuição à emancipação do homem, tomando como ponto de partida as teorias de Adorno, cria um contexto de análise crítica. Mais do que a simples análise positiva do que sujeitos e grupos que buscam uma transformação social fazem ao intervirem na desigual realidade brasileira, busca-se compreender também as reproduções, mesmo que involuntárias, das estruturas de dominação tão criticadas.

Consideramos essa abordagem importante, tendo-se em vista que as posturas frente ao movimento social e seus participantes são por vezes altamente apaixonadas e unilaterais, recusando-se a ponderar, de antemão, elementos que sejam divergentes do ponto de vista defendido.

Durante o levantamento bibliográfico e a coleta de dados para a realização desta pesquisa, pudemos constatar que o material produzido sobre o movimento, seja ele acadêmico ou de outro tipo, tende a assumir duas direções antagônicas, dependendo da posição ideológica de quem o escreve: o produzido por militantes, por acadêmicos ligados 
ao MST ou simpáticos à causa, ou pela mídia ligada à esquerda tendem a ser extremamente ufanistas, romantizando o MST e as pessoas que o integram, e surdos a qualquer crítica, que é logo rotulada como "direitista".

Por outro lado, documentos produzidos por teóricos de direita ou pela mídia de mesma orientação política, são altamente desqualificantes do movimento social em si, desconsiderando toda sua contribuição no avanço das relações democráticas na sociedade brasileira, e caracterizando seus participantes como subversores da ordem ou baderneiros, alardeando a reforma agrária como dispendiosa e não mais necessária (GRAZIANO, 1996; NAVARRO, 2002). Por vezes incontáveis, essas críticas são desprovidas de conteúdo e usam de adjetivos pejorativos e ironia para escamotear sua falta de reflexão racional, como pudemos ver no caso da Revista Veja acima citado. Mesmo os textos acadêmicos mais elaborados, não escondem uma paixão irracional, defendida com argumentos nem sempre bem embasados.

Poucos foram os documentos encontrados que assumiam uma posição de apoio ao Movimento, mas com uma leitura crítica dos problemas que ele enfrenta. Considerando que nenhuma pesquisa é isenta, esclarecemos que a presente pesquisa se insere nessa perspectiva, de ser partidária da luta pela terra, pela transformação da sociedade e pela emancipação do homem, numa postura de claro apoio e incentivo à ação do MST em sua luta por justiça social e reforma agrária, mas com um olhar crítico que visa ajudar a pontuar os elementos internos que merecem um maior investimento dos participantes do MST, a fim de que o Movimento mantenha-se vivo e atuante, contribuindo assim com o avanço da igualdade na sociedade brasileira. 
Inicialmente, no primeiro capítulo, buscamos construir um panorama da teoria de Theodor W. Adorno, especificamente de sua Psicologia Social, que irá embasar a análise realizada no presente estudo.

No segundo capítulo, fizemos uma revisão de algumas das teorias que versam sobre a participação dos indivíduos em grupos e movimentos de massa, procurando comparar as diferentes abordagens e suas contribuições para a compreensão do fenômeno.

No terceiro capítulo, a questão agrária no Brasil, pano de fundo do surgimento dos movimentos sociais no campo, entre eles o MST, é enfocada. Esclarecemos que neste trabalho, quando nos referimos ao Movimento dos Sem Terra, utilizamos a sua sigla, ou simplesmente utilizamos o termo "Movimento", que é como ele é chamado pelos militantes e pelos assentados que dele participam. Nesse capítulo, também discorremos sobre o MST, movimento social que é objeto de nosso estudo. Para isso, o ponto de partida escolhido foi a construção de um panorama histórico a respeito do MST, passando por seus objetivos, até chegar ao seu funcionamento no momento atual. Enfocamos também a atuação do Movimento na organização e o funcionamento de um assentamento, incluindo sua contribuição para a configuração dos assentamentos da reforma agrária.

Parte dos dados obtidos, os dados escritos, já é analisada nesse capítulo. Com relação aos documentos escritos, analisamos os que versavam sobre a organização do assentamento, que nos foram fornecidos pela liderança regional do MST. Esses documentos serviram de balizamento para a discussão da organização do assentamento Sepé Tiaraju, que foi estudado na presente pesquisa.

Nos capítulos seguintes, passou-se propriamente à análise dos dados de observação e das entrevistas, enfocando a relação entre MST e seus participantes. Dentre as possíveis abordagens qualitativas, optamos pelo estudo de caso. As principais características de um 
estudo de caso é que ele se refere ao estudo detalhado de um caso específico, enfatiza a interpretação dentro do contexto, busca retratar a realidade estudada em toda sua complexidade e, principalmente, procura contemplar "os diferentes e, às vezes, conflitantes pontos de vista presentes numa situação social" (LUDKE; ANDRÉ, 2003, p. 20). No caso dos instrumentos de coleta de dados, optamos pela observação participante, a análise documental e a entrevista semi-estrurada.

Para a entrada no campo, inicialmente tivemos que apresentar o projeto para a liderança regional do MST. A autorização para o início da pesquisa teve que ser dada por uma das lideranças em específico, o que demandou tempo e negociação. Após a autorização, fomos ao assentamento e nos apresentamos para a Coordenação do mesmo, não havendo apresentação para o conjunto dos assentados. Essa apresentação foi feita por iniciativa do pesquisador, quando da frequência nas reuniões de núcleo-base e de coordenação.

O assentamento estudado, o PDS Sepé Tiaraju, foi escolhido em função de ser classificado, tanto para o Movimento quanto para o INCRA, como uma experiência-modelo que está sendo testada no Estado de São Paulo. A novidade do assentamento tem relação com o modelo de organização escolhida, denominada pelo INCRA de "Projeto de Desenvolvimento Sustentável" (PDS), e pelo movimento social de "Comuna da Terra", onde parte do lote de produção é coletivo, e a outra parte é individual, para ser trabalhado pela família. Outra característica interessante desse assentamento é o fato de ser o primeiro criado na região de Ribeirão Preto, conhecido pólo de produção canavieira e de forte agricultura patronal.

Participamos em reuniões de planejamento do trabalho e discussões, assembléias, em atividades de agentes externos realizados dentro do assentamento, bem como em outros 
eventos administrativos, sociais, políticos, lúdicos, comemorativos ou culturais, como festas, mutirões, reuniões de planejamento e avaliação, protestos políticos, etc. A frequência das observações variou em função da dinâmica do assentamento e da ocorrência dos eventos observados, mas inicialmente ocorreram de quinze em quinze dias aproximadamente, por dois dias seguidos, e procurando contemplar todos os dias da semana, a fim de garantir um contato suficiente com o cotidiano do assentamento. Posteriormente, foram espaçadas, até ocorrerem uma vez por mês. Como forma de registro das observações realizadas, optou-se pela anotação em cadernos de campo.

As entrevistas ocorreram com oito assentados, entre lideranças ligadas ao MST ou lideranças com cargo de direção no assentamento, bem como com assentados que são referências ou ocupam uma posição de reconhecimento para os outros assentados. Também procuramos entrevistar assentados que estiveram desde as primeiras ocupações promovidas pelo MST na região, e que, portanto, acompanharam a história do assentamento desde seu princípio. As entrevistas foram gravadas com a concordância dos entrevistados.

Cabe observar que foram muitas as conversas registradas, além das entrevistas. Com o tempo, e com a participação da pesquisadora na vida do assentamento, as conversas “ao pé da árvore", na porta dos "barracos", nas reuniões, sem o constrangimento do gravador, fluíam tranquilamente e foram muito proveitosas, indicando que a observação se constituiu um método mais adequado, na presente pesquisa, para levantar dados mais ricos e completos. Nas entrevistas, quando se ligava o gravador, a situação formal fazia com que os entrevistados passassem até a "falar difícil", utilizando palavras rebuscadas, que não faziam parte de seu vocabulário no cotidiano.

Cumpre ainda esclarecer que, como forma de preservar a privacidade, o sigilo e a identidade dos indivíduos que contribuíram com essa pesquisa, os nomes citados nas 
observações, entrevistas e demais dados, foram alterados. Esse cuidado ético gerou algumas situações curiosas: alguns entrevistados, quando informados do fato, antes das entrevistas, verbalizavam o desejo de que seus nomes aparecessem, que não fossem trocados ou omitidos. Em outra ocasião, quando da devolutiva de uma pesquisadora que utilizou os mesmos procedimentos éticos, cerca de quatro ou cinco assentados se reuniram em um dos “barracos”, e leram um artigo referente à pesquisa. Na medida em que liam, falavam: "essa (entrevista) fui eu que dei, isso fui eu que falei. Olha aqui, mais uma fala minha”. Após se identificarem e mostrarem para o outro o que falaram, passaram a identificar as "falas" que não pertenciam a nenhum dos presentes: 'Essa fala pode ser do 'beltrano' ou do 'sicrano', ele que costuma falar isso".

Quanto à análise dos dados obtidos, esta foi realizada no sentido de entender, como afirma Adorno, "na análise de sua estrutura e de seu sentido, a contradição entre a idéia objetiva dessas formações e aquela pretensão, nomeando aquilo que expressa a consistência e a inconsistência dessas formações em si, em face da constituição do estado de coisas existente" (ADORNO, 1986d, p. 89).

Assim, esse esforço é realizado na intenção de fornecer subsídios para a compreensão das contradições a que todos estamos submetidos, no anseio esperançoso de transformação, de emancipação. Esperamos, deste modo, avançar na compreensão da atuação dos movimentos sociais em sua busca por construir relações democráticas e igualitárias. 


\section{A falsidade do todo e a dissolução do indivíduo}

É difícil traçar no fenômeno a linha divisória entre as tendências pessoais e as tendências coletivas: a vida resumida do homem é um capítulo instantâneo da vida em sociedade.

\section{Euclides da Cunha}

Para melhor compreendermos como Adorno analisa a relação do indivíduo com o grupo, precisamos entender melhor sua visão de homem e de sociedade.

Para ele, a possibilidade concreta de uma vida justa para todos, hoje existente, não se efetiva. Vivemos em um mundo onde as forças produtivas, a técnica e a tecnologia encontraram um avanço sem igual, e produzem o suficiente para dar condições de vida para todos os homens, desenhando, de um modo concreto, "a possibilidade de viver sem passar necessidade. Mesmo nos países mais pobres, ninguém mais precisaria passar fome" (ADORNO, 1986c, p. 68).

No entanto, o que se vê na prática é uma deterioração das condições de vida das classes menos favorecidas, e os que estão submetidos a essa situação parecem não só terem se adaptado a isso, como também usam toda sua energia para ajustar-se à sociedade que produz essas condições, agindo contra seus interesses racionais e contra sua própria autoconservação (ADORNO, 1986b; CROCHIK, 1996). 
Assim, cabe perguntarmo-nos sobre que sociedade é essa, que nega uma vida digna aos seus quando esta já é plenamente possível; e que sujeito é esse, que substitui a consciência pelo conformismo e que se submete inclusive a situações contrárias à sua própria sobrevivência.

\subsection{Totalidade e dominação}

Para Adorno, na verdade, pode-se pensar que vivemos hoje em uma sociedade administrada, ou numa sociedade total, onde estão dados de antemão não só os papéis sociais que cada um deve assumir; como também a irracionalidade do sistema se manifesta em cada um dos sujeitos, impotentes e angustiados ante a possibilidade de exclusão frente ao todo social (ADORNO, 1986b; ADORNO, 1992).

O desenvolvimento das forças produtivas alcançado pela nossa sociedade permitiria aos homens atingirem melhores condições de vida e a própria emancipação. Se as forças produtivas avançaram com o avanço da técnica, as relações de produção, no entanto, apresentam aspectos estáticos - há assim um descompasso de uma em relação à outra, ao mesmo tempo em que estão entrelaçadas. Para Adorno, o avanço das forças produtivas não rompeu as relações de produção, como previa Marx, mas estas continuam ancoradas na dominação e na moldagem dos indivíduos às características das máquinas. As relações de produção não abrangem somente as relações de propriedade, mas dizem respeito à administração de toda a sociedade, e interferem também no plano da subjetividade, se desdobrando em relações de dominação (ADORNO, 1986c; MAAR, 1995). 
Assim, as forças produtivas e as relações de produção se expandem para o todo; por exigência econômica, o modelo industrial alcança a administração, a distribuição e até a cultura, que se tornam funções do aparelho de produção (ADORNO, 1986c). A sociedade está inteiramente organizada e pretende impor sua organização a todas as formas de expressão (ADORNO, 1992). Nessa configuração de sociedade, o Estado acaba por cumprir funções de administração do sistema, operando, assim, dentro da mesma racionalidade do todo, chegando, no caso de estados totalitários, a assumir o papel de capitalista total (ADORNO, 1986c; COHN, 1986).

No mundo administrado, a produção material, a distribuição e o consumo são planejados e geridos conjuntamente. Há uma autonomização do sistema diante de tudo, até mesmo dos que detêm os meios de produção (ADORNO, 1986c). As necessidades são totalmente dirigidas, suscitadas pelo próprio sistema, no interesse do lucro, em detrimento das necessidades objetivas dos indivíduos (ADORNO, 1992). É, na verdade, uma sociedade totalitária, onde impera uma regressão do espírito objetivo, e que induz todos à regressão (ADORNO, 1992).

As pessoas não levam uma vida autêntica; as experiências que elas têm não podem sequer ser chamadas de experiências, pois são meras "vivências". A vida reta, justa e plena não existe, se tornou apenas aparência. Aquilo que antes era chamado de vida, passou primeiro para o domínio da esfera privada, e hoje somente se arrasta como apêndice do processo de produção, tendo como função manter uma falsa ilusão de que existe liberdade e autonomia para os indivíduos (ADORNO, 1986, 1992).

O conceito adorniano de experiência, inspirado em Walter Benjamin, faz referência a uma situação em que a história e o conteúdo individual se articulam com a história e o conteúdo coletivo, sem subsumir um ao outro. Como essa articulação se dá pela via do 
simbólico, o próprio pensamento é experiência; pensamento entendido como pensamento pleno, não restringido, que não anula o objeto, mas é uma relação entre este e o sujeito (BENJAMIN, 1983).

Nesse sentido, a experiência (Erfahrung) é entendida por Adorno como um processo dialético entre sujeito e realidade, socialmente mediada, baseada na tradição compartilhada, na transmissibilidade e na comunidade, e que tem como características ser uma relação refletida e preenchida com o vivido, ser uma possibilidade de percepção plena, cheia de sentido e que exige uma reflexão e uma imaginação ativa (ADORNO, 1992; BENJAMIN, 1983, 1987). A experiência pressupõe comunicabilidade e compartilhamento entre os homens, isto é, o conteúdo produzido pela experiência pode ser compartilhado e compreendido por um grupo de indivíduos, fazendo sentido para estes.

Já a vivência (Erlebnis) é algo imediato, momentâneo, anterior às elaborações mentais que podem ser feitas quando se tem uma experiência (AMATUZZI, 2007). Erlebnis se refere a algo da ordem do privado, do individual, e como tal, não é compartilhável nem comunicável, não servindo para aproximar os homens, nem para significar suas ações. Na vivência, não há absorção do conteúdo, com uma real modificação do indivíduo, mas apenas o "choque", a sensação é fragmentária, cada percepção é alheia às outras, desarticulada uma da outra, meramente subjetiva que se esgota em si mesmo, que não é realmente percebida, elaborada e integrada. Além disso, a vivência é eminentemente solitária, em comparação com a experiência que, como já vimos, pressupõe um compartilhamento de significados, uma história e uma identidade coletiva (ADORNO, 1992; AMATUZZI, 2007; BESSA, 2006; BENJAMIN, 1983, 1987).

Há que pontuar, no entanto, que a vivência também apresenta seus aspectos positivos. A descontinuidade entre uma percepção e outra permite ao desejo estar sempre 
nascendo de novo, o que aponta para a existência de novas chances, de novas possibilidades, e para a promessa não realizada de um ser humano livre (CROCHIK, 2007; GAGNEBIN, 2001). Amatuzzi (2007) postula que, para haver experiência, inicialmente é preciso ter havido vivência, isto é, um contato imediato e afetivo com o objeto, que depois pode ser transformado em experiência, desde que penetre, de forma não traumática, no mundo subjetivo do indivíduo (AMATUZZI, 2007; CROCHIK, 2007).

Por outro lado, a característica da vivência é um contato passivo com a realidade, onde o fato é percebido e registrado, mas não é refletido. O tipo de conhecimento que ela produz é denominado por Adorno de semiformação (Halbbildung), e se caracteriza por ser algo marcadamente exterior ao indivíduo, estranho a ele, que vem de fora e é assimilado sem questionamentos, servindo para reforçar a adaptação dos indivíduos ao todo societário, empobrecendo o mundo interno do indivíduo, à medida que o enche de conteúdos heterônomos (MAAR, 1995; ZUIN; PUCCI; RAMOS-DE-OLIVEIRA, 1999).

Já com a experiência, o indivíduo se modifica, isto é, a realidade é refletida e, no contato com esta, há uma transformação interna no sujeito, uma modificação em sua subjetividade, no sentido de propiciar uma autorreflexão que enriquece seu mundo interno e aumenta sua autodeterminação e sua autonomia (MAAR, 1995; ZUIN; PUCCI; RAMOSDE-OLIVEIRA, 1999). Adorno vai nomear esse processo de Bildung, ou verdadeira formação cultural, que pressupõe a existência de reflexão, de um conteúdo compartilhado pelas pessoas e de uma memória coletiva que só pode ocorrer quando há experiência.

Assim, a experiência pressupõe o pensamento livre e questionador, a capacidade para a reflexão e para a seriedade, a capacidade para lidar com o que não está pré-formado e, portanto, uma consciência da tensão, a capacidade para lidar com os extremos, com a contradição (ADORNO, 1986e). 
Na nossa sociedade, a experiência entrou em decadência, e foi substituída pela vivência, pela sensação, pelo clichê, por uma naturalização não refletida do que acontece ao indivíduo, bem como por uma passividade somada a uma recepção ávida (ADORNO, 1992; BENJAMIN, 1983, 1987; COSTA, 2004; GAGNEBIN, 2001).

A experiência não é compatível com o modo de vida nessa sociedade, com o ritmo exigido pela organização da produção e do consumo. Há um declínio das atividades coletivas (festas tradicionais, atividades coletivas e simbólicas), que ancoravam e significavam as experiências individuais. Assim, no lugar da experiência se coloca a busca desenfreada pelo novo, pela sensação, pelo "choque"- algo meramente subjetivo, sem relação com o objeto em si, um conhecimento fragmentado, estanque e isolado (ADORNO, 1986, 1992; COSTA, 2004). Por outro lado, essa sensação de novo é apenas aparência, visto que não há nada de novo nesse mundo administrado, tudo é falso, eterna repetição do mesmo com roupagem de novidade, um retorno compulsivo do antigo (ADORNO, 1992; CROCHIK, 2007).

A aparência de que ainda existe um indivíduo autônomo, livre, de que há possibilidade de escolha, de que há racionalidade e necessidades objetivas, é necessária para manter a dominação e o próprio sistema como um todo. Considerando que a ideologia é a justificativa para a dominação e substitui a violência imediata; a própria realidade, como se apresenta - como aparência, se tornou ideológica (ADORNO, 1986d).

Nessa sociedade, a própria esfera de consumo tem sua existência meramente suportada, pois a pretensão do sistema é substituir um sistema de mediação universal social (relação de troca baseado no princípio de equivalência geral) por um sistema de dominação imediata, sem mediações (ADORNO; HORKHEIMER, 1985). A função da esfera de consumo seria a de simular a existência de uma vida e liberdade de escolha que já não 
existem mais (simulacro de vida) (ADORNO, 1992). Com o aparelho de distribuição da indústria substituindo a esfera de circulação, o domínio privado é devorado, o privado passou a ser o privativo.

Compreender o processo de Esclarecimento talvez nos ajude a entender melhor essa sociedade. Adorno e Horkheimer (1985) entendem Esclarecimento como o processo de substituição da explicação mítica da natureza pelo saber. No processo de desenvolvimento do Esclarecimento, os homens trilharam o caminho do pensamento matemático e tecnicista, que é extremamente factual, pragmático, mercantilista; que renuncia ao sentido das coisas e o substitui por fórmulas (ADORNO, 1992; ADORNO; HORKHEIMER, 1985). O pensamento matemático se torna a única forma de pensamento sancionada, o que leva a uma coisificação do espírito e a uma condenação do que é metafísico. Com isso, o homem passou a valorizar como saber somente o que é empiricamente provado, abrindo mão da busca pela verdade, da busca pelo sentido (ADORNO; HORKHEIMER, 1985).

Cabe salientar que o problema não é o Esclarecimento ou a técnica em si, pois como dizem Adorno e Horkheimer (1985, p. 13), “a liberdade na sociedade é inseparável do pensamento esclarecedor", mas o seu enredamento nas relações sociais, sua utilização para a dominação. Adorno lembra que o interesse de lucro e a necessidade de controle dirigem a técnica e seu desenvolvimento (ADORNO, 1986). Na verdade, há um entrelaçamento dialético entre esclarecimento e dominação.

O Esclarecimento, que levaria o homem a um estágio de conhecimento maior, perdeu a capacidade de refletir sobre si mesmo. O pensamento, excessivamente engessado pelo seu caráter pragmatizado, e por isso incapaz de se autocriticar, não consegue perceber que o progresso que enseja é autodestrutivo. Com isso, o Esclarecimento teria deixado de 
lado seu potencial superador, passando por isso a temer a verdade e, contradizendo sua ambição original, acaba retornando ao mito (ADORNO; HORKHEIMER, 1985).

A natureza e os homens são despidos de sua transcendentalidade, e investidos com uma objetividade matemática e reificante, que os tornam passíveis de manipulação para análise, classificação e, no fim, dominação. Como não se busca mais o sentido das coisas, homens e natureza objetivados perdem suas qualidades, isto é, não mais interessa aquilo que os diferencia uns dos outros, mas sim como podem ser apreendidos pela racionalidade dominadora (ADORNO; HORKHEIMER, 1985). Para Adorno e Horkheimer, “(...) a ordem burguesa estabelecida funcionalizou completamente a razão. Ela se tornou a finalidade sem fim que, por isso mesmo, se deixa atrelar a todos os fins" (1985, p. 87).

O pragmatismo e o utilitarismo sancionado por essa razão dominadora, a razão instrumental, passaram a ser a medida de racionalidade de tudo.

A razão instrumental apresenta o mundo administrado como coerente e lógico, quando na verdade ele é cindido e irracional, sob a forma de uma pretensa racionalidade. Ele se apresenta como racional porque as técnicas de produção e as regras de troca (intercâmbio de equivalentes) no mercado são fundadas sobre uma lógica racional; ao mesmo tempo, ele é irracional, porque está construído sobre uma visão coisificada do homem e uma divisão alienante do trabalho, e para se manter e se reproduzir como sociedade, exige ações irracionais de seus membros (ADORNO, 1986).

Auschwitz seria um exemplo contundente dessa racionalidade irracional - uma racionalidade particular dentro de uma irracionalidade total, visto que os métodos, técnicas, o controle do processo e a administração empregados no campo de concentração utilizavam o que havia de mais avançado econômica, matemática e tecnicamente, enfim, planejado e 
organizado segundo uma racionalidade instrumental, ao mesmo tempo que de uma barbárie que se imaginava superada pelo progresso esclarecido (ADORNO, 1986).

Podemos com isso perceber que há um entrelaçamento entre progresso, técnica e regressão, cujo resultado é progresso da técnica e a regressão do indivíduo (ADORNO, 1992). Assim, a transformação em objeto e a coisificação do espírito têm como consequência a coisificação dos próprios homens, seja na relação de uns com os outros, seja na relação do próprio homem consigo mesmo (ADORNO; HORKHEIMER, 1985). Essa fragmentação se estende ao mais recôndito do indivíduo. A matematização das relações e dos indivíduos e o processo de transformação da força de trabalho em mercadoria permeiam todos os homens, "tornando a priori comensuráveis cada um de seus impulsos, como uma variante da relação de troca - que torna possível a vida reproduzir-se segundo as relações de produção imperantes" (ADORNO, 1992, p. 201), e determinando que todos sejam objetos (ADORNO, 1992; ADORNO; HORKHEIMER, 1985). Assim, o esclarecimento se degenerou em dominação tanto da natureza quanto dos próprios homens, isto é, em totalitarismo (ADORNO; HORKHEIMER, 1985).

O pensamento matemático é totalitário porque entende que os resultados dos processos estão decididos de antemão, cabendo ao homem somente descobri-los, colocando assim o homem sob a força de um destino que é mais forte que ele (ADORNO; HORKHEIMER, 1985). A praticidade do número e sua utilidade para a dominação decorrem de sua capacidade de ser o equivalente geral por excelência, pois ele serve para igualar, quantificar e medir tudo e todos. E o mundo administrado está submetido como um todo à lei do equivalente, e submete todos a esta. A universalização do princípio de troca transforma o mundo no todo idêntico, na totalidade, em mercadoria (ZUIN; PUCCI; RAMOS-DE-OLIVEIRA, 1999). 
A sociedade também é totalitária, sob o aspecto de que os homens são obrigados a usar todas as energias de seu Ego para adaptar-se a ela, deixando de lado o seu próprio eu, a sua identidade. Assim, ele só alcança sua autoconservação à custa de uma regressão autoprescrita, de uma identidade com o todo falso (ADORNO, 1986b, 1992). Nessa vida padronizada, o "mecanismo de identificação imediato do indivíduo com a instância social (...) há muito já se apoderou dos modos de comportamento supostamente normais" (ADORNO, 1992, p. 56).

É a esse processo, essa identidade com o todo falso, que Adorno vai nomear de coletivismo alienante. É uma sociedade que exige dos seus membros uma socialização radical, que "significa alienação radical” (ADORNO; HORKHEIMER, 1985, p. 66). Assim, esta não é uma sociedade individualista, no sentido de que não há mais indivíduos, mas é uma sociedade coletivista, que coage ao coletivismo, ao acabar com as diferenças qualitativas e ao reduzir tudo a uma igualdade para a dominação (ADORNO, 1992). Como já dissemos anteriormente, o discurso da liberdade do indivíduo é na verdade uma falsidade para encobrir o fato de que não há liberdade, que estão dados de antemão não só o papel que o indivíduo deve assumir na sociedade, mas as escolhas que ele pode fazer.

As pessoas pensam em bloco, e trocaram a reflexão por reflexos pré-determinados. Na sociedade de produção em série, o próprio pensamento é produzido em série; questões complexas são naturalizadas e respondidas a partir de modelos conceituais e termos técnicos vazios, que independem do objeto (ADORNO, 1992; ADORNO; HORKHEIMER, 1985). O pensamento, cada vez mais supérfluo, passa a ser considerado apenas mais um setor especializado da divisão do trabalho. Não há mais juízo, que necessita de discriminação e ponderação; mas uma simplificação, uma classificação em categorias, um mero reagir não-reflexivo: "as etiquetas são coladas: ou se é amigo, ou inimigo" 
(ADORNO; HORKHEIMER, 1985, p. 188). Adorno chama de "mentalidade do ticket" esse pensar em bloco, onde a estereotipia substitui o trabalho categorial, e o indivíduo assume opiniões em bloco, onde "tomar posição", ter opinião sobre o que está acontecendo na verdade é uma escolha por alguns dos blocos de opinião socialmente sancionados; uma necessidade para se sentir socialmente incluído (ADORNO, 1992; ADORNO; HORKHEIMER, 1985).

Dentro desse cenário, a indústria cultural assume um papel importante para a reprodução do todo e a adaptação dos homens à sociedade administrada. A diversão e o entretenimento, que a indústria cultural pretensamente propicia aos seus consumidores, têm como função evitar a reflexão e administrar os espíritos, integrando-os e reforçando a substituição da consciência pelo conformismo (ADORNO, 1986f)

Com a transformação dos bens culturais em mercadorias, a hora de lazer passa a ser uma continuação da mesma racionalidade que dirige os trabalhadores na fábrica: não há nenhum momento do dia que não é dirigido por uma racionalidade técnica e instrumental, que não seja uma repetição mecânica do já dado; o horário de lazer é cuidadosamente e meticulosamente planejado para ser uma "reprodução do que é sempre o mesmo" (ADORNO; HORKHEIMER, 1985, p. 126), segundo a mesma lógica automatizada das operações padronizadas da produção em série (ADORNO, 1986f; ADORNO; HORKHEIMER, 1985).

Nesse sentido, a indústria cultural usa a figura do ídolo para adaptar o indivíduo ao todo social: ao parecer alguém comum que conseguiu vencer na vida, faz com que o espectador se identifique com ele, e passa a sensação de que o espectador poderia estar naquele lugar, ser ele o vencedor. $\mathrm{O}$ que há de individual em cada artista reforça a aparência de que ainda existem indivíduos, bem como serve de asseveração de que aquele 
que está na tela é igual ao espectador e que, portanto, não é absolutamente necessário ser diferente do que já se é para obter sucesso na vida (ADORNO, 1986f; ADORNO; HORKHEIMER, 1985).

Quanto à análise de Adorno sobre o meio rural e as comunidades que aí existem, o autor pontua que não é possível compreender o campo sem entender a sua relação com a cidade, bem como a integração da ambos na dinâmica geral da sociedade (HORKHEIMER; ADORNO, 1973).

As próprias atividades rurais, seja no plano social, cultural ou econômico, são determinadas em grande parte pela dinâmica econômica da região urbana à qual aquela zona rural está ligada. A influência da zona urbana se faz sentir de forma bastante intensa na zona rural, e há um declínio do modo de vida camponês típico, que é substituído por considerações de ordem econômicas e pela mesma homogeneização de comportamentos e das formas de vida percebidas nas cidades (HORKHEIMER; ADORNO, 1973).

Para Adorno, elementos da economia pré-capitalista doméstica persistem no meio rural a par de elementos ditos modernos, que têm relação com a cultura de massa e com o consumo, incluindo aí os bens e os produtos da indústria cultural (HORKHEIMER; ADORNO, 1973).

Para parte da população rural, a terra ainda mantém um valor de intocabilidade, em função da autonomia, da independência e da auto-suficiência que ela proporciona. Dessa forma, o homem do campo resiste mais do que nenhum outro ao desapossamento levado a cabo pelo capitalismo e por sua racionalidade. Por outro lado, Adorno frisa que essa resistência do camponês não significa uma a-historicidade do modo de produção campesino, como querem alguns teóricos que romantizam a vida rural, mas pode significar um conservadorismo e uma tendência à inércia (HORKHEIMER; ADORNO, 1973). 
A "defasagem cultural" do campo em relação à cidade também é entendida como bastante perigosa (HORKHEIMER; ADORNO, 1973, P.161). Essa defasagem pode permitir a penetração de ideologias totalitárias, o que leva Adorno a postular como importante e urgente a educação para a "desbarbarização" do campo (ADORNO, 1986; HORKHEIMER; ADORNO, 1973).

Assim, o campo é visto por ele como sendo ainda menos desbarbarizado do que a cidade, e a presença dos meios de comunicação de massa não conseguiu alterar ainda a situação de "defasagem cultural" em relação às zonas urbanas (ADORNO, 1986). As modificações culturais no campo ocorrem mais lentamente do que as modificações em suas condições materiais de produção, e assim, as vantagens do esclarecimento ainda não teriam sido apropriadas da mesma forma que na cidade (HORKHEIMER; ADORNO, 1973).

Por outro lado, cabe evidenciar que no texto "A indústria cultural" (1985, p. 124), os autores pontuam que precisamente esse descompasso em termos culturais é que pode deixar "ao espírito um resto de autonomia" e assegurar aos que vivem esse atraso "a possibilidade de existir ainda que oprimidos".

Adorno também critica a visão romantizada sobre o meio rural, que o coloca como conservador de elementos culturais mais puros, ainda não deformados pela indústria cultural, sendo que a tradição camponesa e a cultura tradicional já foram absorvidas pelo todo social, sendo instrumentalizada e usada pela indústria cultural como aparência de que há espaço para o dissonante (ADORNO, 1986d).

Outro ponto abordado por Adorno diz respeito ao retorno de populações da cidade para o campo, em um processo que ele chama de "re-ruralização": para ele, isso se dá de forma bastante problemática, levando-se em conta que a influência urbana modifica não só as condições objetivas de existência no campo, mas também o funcionamento psicossocial 
dos indivíduos que vivem na zona rural (HORKHEIMER; ADORNO, 1973). Outrossim, considerando que mesmo o que é estranho ao sistema acaba por ser instrumentalizado e absorvido por ele, mesmo os participantes da reforma agrária não escapam desta absorção, e a tendência é de sobreviver integrando-se ao sistema capitalista:

Quem resiste, só pode sobreviver integrando-se. Uma vez registrado em sua diferença pela indústria cultural, ele passa a pertencer a ela assim como o participante da reforma agrária ao capitalismo. (ADORNO; HORKHEIMER, 1985, p. 123).

\subsection{O indivíduo e a subjetividade danificada}

Considerando que cada época produz os tipos psíquicos que mais se adéquam à sua necessidade, cabe pensar como se forma e como se comporta o sujeito nessa sociedade. Adorno enxerga o homem dentro dessa sociedade como uma "pequena empresa" psicológica, regida pelas leis de produção. O processo produtivo e a lógica do esclarecimento que permeiam toda a sociedade se impõem ao sujeito, e a mesma racionalidade instrumental e técnica que constrói a sociedade, o constrói (ADORNO, 1992).

Para Adorno, a sociedade obriga o indivíduo à regressão e o submete a uma dominação integral (ADORNO, 1986b). Os determinantes psicológicos do indivíduo não desapareceram, mas encontraram uma função e um lugar bem determinado dentro do 
sistema de dominação (ADORNO; HORKHEIMER, 1985). A vida é mera aparência, o indivíduo é um ser sem experiências verdadeiras, e as suas mais secretas reações são determinadas pelo mundo administrado (ADORNO, 1992).

Adorno considera que esta não é mais uma sociedade edípica, como a que Freud havia estudado em seu "Mal Estar na Civilização", mas infantilizada, regredida e parricida, onde não há mais sutilezas, e os indivíduos se apresentam sem resistências, ao mesmo tempo alertas e inconscientes (ADORNO, 1992).

A relação entre os homens são "relações", ou seja, os homens se relacionam com os outros como objetos, assim como vêem a si próprios como objetos, seguindo os preceitos da racionalidade instrumental dominante (ADORNO, 1992; ADORNO; HORKHEIMER, 1985). As convenções sociais que regiam as relações entre os homens foram abolidas, mas nem por isso o indivíduo se tornou mais livre ou autônomo, posto que a extinção das convenções somente aboliu o mais superficial: a dominação passou a ser imediata, e não mais mediatizada por regras sociais (ADORNO, 1992). Assim, hoje se vive uma vida de dominação imediata, onde o indivíduo não foi completamente eliminado, mas arrasta-se como um apêndice sem vida do processo produtivo (ADORNO, 1992).

Como o princípio do equivalente se aplica a tudo e a todos, e há uma autonomização do sistema diante de tudo, todos são objetos, dominantes e dominados, e estão sujeitos a uma auto-alienação para não serem excluídos. Nenhum indivíduo consegue mais determinar sua vida, "o indivíduo enquanto indivíduo, como representante do gênero humano, perdeu a autonomia através da qual poderia realizar efetivamente o ser humano" (ADORNO, 1986b, p. 74).

Para tentar auto-conservar-se, o indivíduo anula a vida na subjetividade, trabalha ativamente e de forma compulsiva para se inserir, para se submeter, para adaptar-se à 
dominação, se transformando num sujeito sem subjetividade, cativo (ADORNO, 1986b, 1992).

Dentro da sua teoria, assume um papel importante o conceito de "consciência coisificada", que se refere ao indivíduo que rejeita conscientemente toda reflexão, toda consequência, nega o próprio condicionamento e aceita voluntariamente e incondicionalmente o que já é dado, trabalhando ativamente para se inserir em um sistema que atua muitas vezes contra seus próprios interesses (ADORNO, 1986). O indivíduo com a consciência coisificada se enxerga como coisa, como objeto, e enxerga os outros como objeto também (ADORNO, 1986; ZUIN; PUCCI; RAMOS-DE-OLIVEIRA, 1999).

A adaptação a qualquer custo é motivada pela angústia e o medo ante a possibilidade de exclusão do todo social, vigente inclusive para aqueles que não precisam temer a exclusão econômica (ADORNO, 1986b).

Nesse processo, o Ego passa a funcionar como coisa, como equipamento cuja função é adaptar o homem à sociedade, de tal maneira que o indivíduo passa a existir sem um Eu, ou seja, o Eu concede a si próprio ao mundo administrado, num processo de tentar auto-conservar-se, a tal ponto que deixa de ter existência real e passa a ser um mero ponto de referência, abstrato (ADORNO, 1992). Suas qualidades são manipuladas, moldadas e alteradas de tal forma que se tornam desprovidas de qualquer traço pessoal, deixam de ser do indivíduo, ainda que ele se refira a elas como objetos internos (ADORNO, 1992).

Considerando que o Ego é uma instância mediadora, que permite tanto uma diferenciação externa quanto interna, no primeiro caso pela organização das pulsões e pela substituição de objetos, e no segundo pela modificação da realidade, com o Ego como mero ponto de referência, perde-se a mediação e a consequente diferenciação, e as reações do indivíduo passam a ser rápidas, simples reflexos de pronta resposta (CROCHIK, 1996). 
Para Adorno (1986b), o próprio Ego é contraditório, pois ao mesmo tempo é psíquico e não-psíquico, em parte libido e em parte representante do mundo, consciente e inconsciente, antítese da repressão e instância repressora. Essa contradição do Ego, permitida pela sua estrutura, é fruto das exigências da sociedade que, através do princípio de realidade, invade não só o ego, mas toda subjetividade humana, utilizando-a a serviço do sistema. A sociedade burguesa/capitalista pede aos indivíduos uma existência mutilada (ADORNO, 1986b; CROCHIK, 1996).

Os indivíduos estão infantilizados e regredidos a tal ponto que não chegam a uma integração das pulsões parciais. Com o abandono e a mudança constante de objeto, característicos dessa sociedade, o Ego regride ao Id, as pulsões são manipuladas diretamente, o desejo é continuamente suscitado, mas nunca é realizado. A livre expressão do desejo é sancionada, desde que não esteja em desacordo com a ordem estabelecida. Como a realização da pulsão está bloqueada pela realidade, o indivíduo age por compulsão, e não por prazer (CROCHIK, 1996).

Também nesse processo tem participação a indústria cultural. Esta continuamente suscita o desejo dos indivíduos, de uma forma compulsiva, em um processo que reprime em vez de sublimar. Esse processo, que ficou conhecido como "dessublimação repressiva" (MARCUSE, 1982; ZUIN; PUCCI; RAMOS-DE-OLIVEIRA, 1999), consiste em excitar o prazer preliminar não sublimado com promessas de satisfação que são sempre frustradas, substituídas pela renúncia, e a realização do prazer é substituído pelo recalcamento do desejo, em um processo compulsivo e masoquista (ADORNO; HORKHEIMER, 1985).

Há uma cisão interna e uma separação do Ego de sua base pulsional e de suas características próprias, resultado da objetivização radical do indivíduo, reflexo de uma organização interna em acordo com a divisão do trabalho (ADORNO, 1992). 
O superego, enquanto instância do aparelho psíquico constituída a partir do social, também é instrumentalizado pelo mundo administrado. Já não há uma constituição própria do superego, mas seu conteúdo é dado a partir de fora.

Há uma substituição do superego individual por autoridades externas, de forma imediata. O ideal de ego é substituído por algo exterior ao indivíduo, seja alguém, algum grupo ou idéia; e os indivíduos se igualam uns aos outros de forma narcísica (ADORNO, 1986b).

Ademais, o superego coloca diante do indivíduo aquilo que é socialmente proibido como o mal em si, e funde irracionalmente a antiga angústia ante a liquidação física com a da aniquilação social, da exclusão, contribuindo assim para manter a alienação do homem e sua adaptação ativa à dominação (ADORNO, 1986b).

Na verdade, estamos falando de um indivíduo que não é indivíduo, de um sujeito sem subjetividade, de um ser heterônomo, isto é, determinado a partir de fora; que já não tem nenhuma capacidade de autonomia, de auto-determinação: "desprovidos de resistência, o sujeito se extinguiu por completo" (ADORNO, 1992, p. 202).

Assim, nessa sociedade, a objetivação radical do indivíduo - com a sua fragmentação, a perda de suas qualidades, a separação patológica de sua base pulsional, a livre expressão do desejo sem a correspondente realização - causado pela necessidade do ego de se auto-conservar, conduz a uma cisão doentia do ser humano (ADORNO, 1992).

Como a sociedade em que vivemos é cindida, alienada, e totalitária, ela produz sujeitos cindidos, alienados e autoritários, utilizando-se para isso da própria subjetividade dos indivíduos. Cabe lembrar que a subjetividade se forma a partir do mundo externo, mas não se reduz a isso. Uma vez formada, se constitui como um terreno interno que se opõe ao externo, que ao mesmo tempo em que adapta o indivíduo ao seu meio, o diferencia dele, e 
permite que ele possa expressar seus anseios individuais e possa se contrapor à própria cultura que permitiu sua formação (CROCHIK, 1998).

Por outro lado, em nossa sociedade, os traços de caráter ou personalidades que se encaixam com o que é exigido para a sobrevivência nessa sociedade, são valorizados e reforçados. Vivemos hoje em uma sociedade que privilegia o masoquismo e a submissão, com tendências totalitárias (ADORNO, 1992). Não é à toa que há um ambiente social que induz ao racismo exacerbado, ao fascismo e ao autoritarismo.

No famoso estudo "A personalidade autoritária", realizado por Adorno e colaboradores e publicado em 1950, os autores vão procurar compreender os traços de personalidade das pessoas potencialmente adeptas ou simpáticas ao fascismo ou a ideologias autoritárias, atentando para o fato de que a constituição de tais personalidades é socialmente determinada.

Do ponto de vista psicológico, o autoritarismo foi considerado, para os autores, como uma "tendência geral a colocar-se em situações de dominação ou submissão frente aos outros como consequência de uma insegurança básica do Ego" (COLOMBO, 1965, p. 5). O autoritário acha naturais as situações hierárquicas e de mando, acreditando que se deve obediência para com os de cima, e autoridade para com os de baixo. Aquele que tem uma personalidade autoritária identifica-se com o poder enquanto tal, independente do conteúdo professado ou representado por aquele que está na direção (ADORNO, 1995). Adorno vai falar em um "caráter de ciclista", presente no folclore alemão, que é aquele que se curva para o que está acima dele, e chuta o que está abaixo (ADORNO, 2006).

As conclusões do trabalho indicaram que os indivíduos que tendem ao autoritarismo em geral pensam por estereótipos, de forma externalizada (anti-intraceptividade) e tendem à personalização. Esses indivíduos possuem a já pontuada fragilidade do ego, um superego 
externalizado, bem como sinais de convencionalismo, rigidez, estereotipia, negação violenta de tudo aquilo que remete aos próprios impulsos reprimidos, incapacidade de voltar-se para sua interioridade e de assimilar experiências novas (ADORNO et. al., 1965).

O indivíduo com a chamada síndrome da personalidade autoritária não consegue aturar o que é diferente dele; o divergente não é compreendido e deve ser eliminado, tudo deve ser igual e uniformizado (ADORNO, 1986e). O autoritário, em função da ausência de fronteiras do seu ego, se submete a coletivos como forma de se sentir forte e compensar sua fragilidade, bem como volta sua agressividade para o que é diferente dele, como forma de obter uma pseudo-delimitação de sua individualidade e uma pseudo-diferenciação (ADORNO, 1995; ADORNO et. al., 1965).

Os autores concluem pontuando que a tendência ao autoritarismo é um produto social, sendo resultado da internalização de aspectos irracionais da sociedade moderna, e que somente pode deixar de existir com uma mudança da própria sociedade, mas muito pode ser feito no sentido de tornar os indivíduos mais resistentes à adoção de uma postura autoritária, ao fortalecerem sua própria autoridade interna, isto é, a consciência (ADORNO, 2006; ADORNO et. al., 1965).

\subsection{Emancipação e autonomia}

Infelizmente, os ideários ditos progressistas, que visam à superação do capitalismo e à emancipação do homem, acabam reproduzindo a mesma reificação do capitalismo, ao optarem pela racionalidade instrumental presente no Esclarecimento. 
As formas de organização de sociedades socialistas, estudadas e criticadas por Adorno $(1992 ;$ 1986d) pautam-se pelo produtivismo, por um pragmatismo objetivista e pelo burocracismo, tal qual nas sociedades capitalistas. Para o autor, o ordenamento social nas sociedades socialistas apossava-se de todos os fenômenos sociais, incluindo o ócio, e imprimindo a todos eles a marca da ordem. Elas não deixavam de ser um mundo administrado como no capitalismo que criticavam.

As experiências históricas de socialismo, estudadas pelo autor, reproduziriam a mesma sociedade cindida, regressiva e reificante do capitalismo. O mesmo totalitarismo, um idêntico fervor pelo planejamento e administração completa, a mesma racionalidade instrumental, que só vê sentido nas coisas que têm um fim prático e lógico; a mesma matematização das coisas e dos indivíduos, a assunção de um Esclarecimento reificado e sem auto-reflexão.

Adorno critica não somente o socialismo como experiência histórica, mas também os partidos e grupos de esquerda, que repetem a "mentalidade do ticket", que dispensam e desestimulam a capacidade de pensar dos indivíduos, obrigando-os a assumir a ideologia do partido em forma de pacote, isto é, em bloco. Ao concordar com o partido, você deve concordar com tudo, sob pena de ser visto como inimigo, como traidor, "reacionário", e de ser excluído. Segundo Adorno, "atacam o espírito, de resto já insuportável, e nisso ainda se sentem purificadores e revolucionários" (ADORNO, 1986d, p. 83).

Adorno também vai criticar o abandono da dialética pela esquerda, em especial do momento negativo, e a opção por um positivismo exacerbado e pelo pragmatismo, que só quer ver aquilo que interessa, e acaba com o movimento, engessando a história (ADORNO, 1986, 1992). Para Adorno, antes de mais nada, dialética significa "intransigência contra toda e qualquer reificação" (ADORNO, 1986d, p. 88). 
Segundo o frankfurtiano, a esquerda reproduz na prática a posição do mundo administrado, ao só tolerar ou aceitar como verdade aquilo que já é pré-formado, o que é familiar, fazendo com que "a mentira soe como a verdade e a verdade como mentira" (ADORNO, 1992, p. 94), desprezando vozes dissonantes, desqualificando aqueles que ousam colocar uma posição diferente.

Assim, a esquerda não escapa do totalitarismo dessa sociedade, e por assumir a mesma forma de produção e as mesmas relações de produção, com a sua consequente racionalidade - a instrumental, muitas vezes assume o totalitarismo como única possibilidade de ação, de sociedade.

Por outro lado, Adorno deixa vislumbrar em seus escritos a esperança de que um dia as coisas possam ser diferentes. Ao mesmo tempo em que denuncia a dominação totalitária dessa sociedade, a vida danificada e a decomposição do indivíduo, ele anuncia que "por mais insuperável que seja o feitiço, é apenas feitiço" (ADORNO, 1986c, p.75). Para ele, um dia o mundo há de parecer um feriado, ou a alegria de uma criança que volta para casa das férias (ADORNO, 1992).

Cabe então elucidar qual o conceito de emancipação para Adorno, e como podemos chegar a ela.

Para Adorno, emancipação significa justamente libertação da totalidade dominada pela quantificação, pelo princípio do equivalente, pela extensão do atual modelo de produção por toda a sociedade (ADORNO, 1992).

Uma sociedade emancipada estaria livre do produtivismo que vê o desenvolvimento como tendo uma só direção, a do aumento da produtividade e da abundância, da "insaciabilidade de boca cheia", pregado e assumido como único modelo de nova sociedade igualitária tanto pelo capitalismo quanto pelas formas então existentes de socialismo 
(ADORNO, 1992). Ele lembra que as forças produtivas "não são o substrato último do homem, mas representam tão somente a forma histórica de homem, adequada à produção de mercadorias" (ADORNO, 1992, p. 138).

Para ele, a resposta para a inevitável pergunta sobre qual é o objetivo da sociedade emancipada é "que ninguém mais passe fome" (ADORNO, 1992, p. 137). Toda formulação além dessa pode trazer em si o produtivismo dessa sociedade.

$\mathrm{Na}$ sociedade emancipada, o lugar do pragmatismo, do processo produtivo e do fazer compulsivo deveria ser ocupado pelo "ser, e mais nada, sem nenhuma outra determinação nem realização" (ADORNO, 1992, p. 138, citando o dramaturgo alemão Carl Sternheim), e haveria a compreensão de que os seres humanos são "finalidades vivas" em si mesmo.

O produtivismo seria abandonado e a verdadeira sociedade poderia se cansar do desenvolvimento desenfreado e deixar, "por pura liberdade, possibilidades sem utilizar, ao invés de se precipitar, com uma louca compulsão, rumo a estrelas distantes" (ADORNO, 1992, p. 138). O trabalho seria não compulsivo, e o prazer não culposo (COHN, 1986).

Indivíduos autônomos, capazes de julgar e de decidir as coisas de forma consciente, não tutelados, são a condição prévia para a existência de uma sociedade democrática e emancipada (ADORNO, 1986f). Nessa verdadeira sociedade, a subjetividade passaria a ter sentido na medida em que ela se objetivasse na sociedade e no Estado. A racionalidade estaria ancorada em um ego firme, coerente, e não fragmentado e separado de sua base pulsional (ADORNO, 1986d, 1992). Com a conciliação entre razão e emoção, entre pulsões e pensamento, entre subjetividade e objetividade, indivíduo e sociedade estariam finalmente conciliados (ADORNO, 1986d, 1992). 
Cabe frisar que conciliação não significa ausência de tensão. Na verdade, é a tensão entre o indivíduo e a sociedade é que produz a categoria do novo, e a emancipação não pode ser entendida sem a dimensão da capacidade de lidar com essa tensão, ancorada numa auto-determinação dos indivíduos e em uma liberdade verdadeira. Entender a contradição como necessária, como parte da realidade social, faz parte do processo de conciliação do indivíduo com a sociedade (ADORNO, 1986g, 1992).

Justamente por procurar "fugir das soluções fáceis das falsas sínteses", Adorno se recusa a ser contundente quanto ao caminho a se trilhar para chegar à emancipação, mas vai dizer que é imprescindível olhar para o indivíduo, pois justamente aquilo que desaparece deve ser "considerado essencial", isto é, a ação individual, a espontaneidade, a sobrevida anormal e tolerada do que já é nulo - o indivíduo, é por isso mesmo essencial (ADORNO, 1992). Segundo Adorno,

[...] exatamente a rejeição ao culposo contexto de vida a ser cega e rigidamente reproduzido, o gesto de insistir na independência e na autonomia, na separação do vigente reino das finalidades, implica, ao menos de modo inconsciente, a referência a um estado em que a liberdade estaria realizada. (ADORNO, 1986d, p. 80).

Assim, o indivíduo é o momento negativo dessa sociedade reificada, a denúncia da existência de uma outra possibilidade.

Para Adorno, é necessário voltar-se para o indivíduo como possibilidade de resistência à irracionalidade objetiva, de superação num mundo onde a transformação está objetivamente bloqueada (CROCHIK, 1996; GAGNEBIN, 2001). Alguma coisa da força 
social e coletiva de resistência e transformação pode temporariamente ter se retirado para a esfera individual, e é justamente desse indivíduo que existe sem subjetividade, que é mera aparência, que pode surgir, "um dia, sem aparência, a salvação" (ADORNO, 1992, p. 106).

As experiências subjetivas de desajuste e de dilaceramento deixam entrever que é no indivíduo que se encontram algumas possibilidades de resistência contra essa sociedade reificada e de realização do gênero humano. Para ele, sinais de uma recusa à lógica dessa sociedade podem ser vistas na resistência contra a acomodação, busca de liberdade para objetivos racionalmente escolhidos, austeridade, ascese, atenção para as possibilidades de mudança (ADORNO, 1986, 1992; GAGNEBIN, 2001).

É no indivíduo que estão as possibilidades de relações sem interesse, de formação de células de humanidade no meio universal desumano, bem como de conciliação e realização do gênero. Para isso, no entanto, é necessário valorizar o momento negativo da dialética, expor a negatividade extrínseca das coisas, ao invés de propor soluções conciliatórias irreais. Só a exposição das contradições e a evidenciação das tensões pode representar uma chance para o indivíduo se colocar de forma reflexiva e com autonomia frente ao todo falsamente conciliado (ADORNO, 1992; ZUIN; PUCCI; RAMOS-DEOLIVEIRA, 1999).

Cabe lembrar que os indivíduos são pré-formados pelo todo social, e o pensamento e a reflexão são condicionados por essa realidade existente e marcados pela mesma deformação a que ela tudo submete (ADORNO, 1992). Se não é possível superar a contradição desse mundo através do pensamento, porque este também está determinado pelo todo, essa superação é possível através da explicitação, através da transformação da contradição em consciência, com sua expressão através da palavra (ADORNO, 1986e). 
Assim, o pensamento dos indivíduos que existem sem subjetividade deve produzir perspectivas nas quais o mundo se estranhe, revelando suas fissuras e fendas. (ADORNO, 1986e).

Para que isso ocorra, é necessário que onde há inconsciente haja consciente, diz Adorno em consonância com a visão freudiana da primeira tópica (ADORNO, 1986, 1986b). A consciência é uma exigência para a existência de uma nova sociedade, uma sociedade verdadeiramente democrática e constituída de indivíduos autônomos (ADORNO, 1986; ROUANET, 1985). O pensamento esclarecido e sua auto-reflexão, a compreensão dos mecanismos a que o indivíduo está submetido, a explicitação de sua reificação e sofrimento são caminhos para a conscientização e construção da autonomia do sujeito, e podem ser obtidos pela educação, pelo conhecimento psicanalítico, bem como pelas situações de ruptura, que podem abrir brechas no cotidiano cristalizado e burocrático, fazendo o indivíduo ver além do cotidiano reificado (ADORNO, 1992).

Nesse cenário, assume importância capital a idéia de formação, como caminho para a emancipação do homem. Formação (Bildung) é entendida por Adorno como um processo no qual os indivíduos desenvolvem a sua subjetividade, em que ocorre a individuação e a diferenciação de um indivíduo através da constituição de sua personalidade e de seus traços de caráter, sendo que a formação é um processo amplo, que inclui também a educação (ADORNO, 1995b; CROCHIK, 1998; ZUIN; PUCCI; RAMOS-DE-OLIVEIRA, 1999). Conforme já pontuamos acima, a verdadeira formação dos indivíduos só acontece quando há experiência, isto é, um contato refletido e transformador com a realidade (MAAR, 1995).

A experiência formativa, ou a formação verdadeiramente realizada, se caracteriza por envolver uma difícil mediação entre o condicionamento social, o momento adaptativo 
da formação, e o momento de crítica e autonomia da produção individual e subjetiva (MAAR, 1995).

A emancipação é inseparável da verdadeira experiência formativa, que pressupõe o pensamento que reflete sobre si mesmo, a auto-reflexão crítica que rompe com a uniformização do pensamento já dado, com a lógica da identidade com o todo, e produz um conhecimento que penetra no indivíduo e que modifica sua subjetividade, habilitando-o para romper com o enquadramento e a subordinação ao que é heterônomo (ADORNO, 1995b; MAAR, 1995; ZUIN; PUCCI; RAMOS-DE-OLIVEIRA, 1999).

Segundo Adorno, (1986, p. 37) “A única verdadeira força contra o princípio de Auschwitz seria a autonomia, se é que eu posso utilizar a expressão de Kant; a força para a reflexão, para a autodeterminação, para a não participação". 


\section{Sobre a participação dos indivíduos nos grupos}

As massas são, de certo modo, como a esfinge da antiga fábula: há que saber resolver os problemas que sua psicologia nos coloca, ou resignar-se a ser devorado por elas.

\section{Gustave Le Bon}

Antes mesmo do surgimento da psicologia como área do saber distinta das outras ciências, vários estudiosos já colocavam a questão dos fenômenos de grupo, da participação dos indivíduos e das transformações do seu comportamento quando estão agrupados, incluindo aí o papel que os grupos cumprem na economia e dinâmica psíquica dos indivíduos que dele participam.

Freud, quando escreve Psicologia de Grupo e Análise do Ego, em 1921, já reporta a existência de uma "copiosa literatura sobre o assunto" (FREUD, 1996, p. 82).

Não há um sentido unívoco para o termo grupo, nem concordância entre os autores com relação a uma definição para o conceito. Também são diferentes as explicações sobre o seu funcionamento, sua função /papel dentro da sociedade e para os indivíduos que neles participam, bem como acerca do funcionamento mental dos indivíduos imersos em formações grupais (HORKHEIMER; ADORNO, 1973).

Os grupos podem ser analisados sob vários aspectos, e os autores que os estudam vão diferenciá-los quanto a serem duradouros ou passageiros, organizados ou não, com ou 
sem líderes, abertos ou fechados, estáveis ou instáveis, entre outros aspectos possíveis de serem listados (CANETTI, 2005; FREUD, 1996; HORKHEIMER; ADORNO, 1973).

Uma das principais diferenciações feitas pelos autores se refere à distinção entre grupos e massas. Em geral, os autores vão reportar aos primeiros um certo grau de organização ou institucionalização, um caráter formal, com os sujeitos dele participando sem perder suas características individuais.

O grupo pode ser constituído tendo por base elementos de vinculação objetiva e/ou elementos de vinculação subjetiva, ou seja, os indivíduos podem ter ou não consciência de sua participação em um grupo, sendo um exemplo do primeiro caso um partido político, onde há uma consciência coletiva, um sentimento de "nós", e exemplos do segundo caso, o pertencimento ao grupo de trabalhadores de um determinado país (HORKHEIMER; ADORNO, 1973). Assim, com relação ao termo grupo, os autores vão comentar que ele é tão amplo e impreciso quanto indispensável.

Já as massas são caracterizadas por serem formadas por uma grande concentração de indivíduos, com um certo apagamento das fronteiras da individualidade, por uma influenciabilidade do comportamento de seus participantes, bem como uma propensão a atuar de forma imediata e nem sempre racional (ADORNO, 2006).

Um aspecto semelhante nos autores estudados é que, independente da posição teórica ou ideológica assumida, todos identificam uma origem pré-histórica para a formação dos grupos e das massas. Essas teriam surgido junto com a humanidade, sendo a origem das sociedades humanas indissociáveis da origem dos grupos. Para Freud (1996, p. 134), inclusive, "a psicologia dos grupos é a mais antiga psicologia humana". 


\subsection{Le Bon e a caracterização das massas}

Gustave Le Bon, teórico de quem Freud vai partir para elaborar sua teoria sobre o funcionamento dos grupos, escreveu o estudo "Psychologie des Foules" em 1895. Em função deste trabalho, ele passou a ser considerado por muitos como um dos fundadores da disciplina chamada de psicologia social (BURILLO, 2005). Em "Psicologia das Massas", Le Bon se propõe a analisar o funcionamento das massas, bem como o funcionamento psíquico das pessoas quando delas participam, e o que as mantém unidas.

Cabe observar que em seu texto, Le Bon se refere à "foule", discorrendo mais sobre agrupamentos humanos com características que os autores costumam reportar às massas ou à multidão, mais do que a um grupo organizado, ainda que o autor considere a reunião de um pequeno número de pessoas como uma massa, o que se dá no caso de um júri ou de um grupo de 'experts' em um assunto, quando estão discutindo algo que está fora de seu campo de conhecimento.

Em determinadas circunstâncias, e somente nelas, uma aglomeração de seres humanos possui características novas e muito diferentes das de cada um dos indivíduos que a compõem. A personalidade consciente se esfuma, os sentimentos e as idéias de todas as unidades se orientam em uma mesma direção. Se forma uma alma coletiva, sem dúvida transitória, mas que apresenta características muito definidas. A coletividade se converte então em aquilo que, por falta de melhor expressão, designarei como massa organizada ou, se preferirmos, massa psicológica. Forma um 
só ser e está submetida à lei da unidade mental das massas. (LE BON, 2005, p.27).

À semelhança de Freud, partiremos de uma citação de Le Bon que resume sua teoria sobre as massas:

O fato mais chamativo que apresenta uma massa psicológica é a seguinte: sejam quais forem os indivíduos que a compõem, por semelhantes ou distintos que possam ser seu modo de vida, ocupações, caráter ou inteligência, o simples fato de que se tenham transformado em massa os dota de uma espécie de alma coletiva. Esta alma os faz sentir, pensar e agir de um modo completamente diferente de como faria cada um deles isoladamente. Determinadas idéias e certos sentimentos não surgem ou não se transformam em atos, exceto no caso de indivíduos que formam uma massa. A massa psicológica é um ser provisório, formado por elementos heterogêneos que por um momento se combinam, exatamente como as células de um corpo vivo formam, por sua reunião, um novo ser que manifesta características muito diferentes das que possui cada uma das células que o compõem. (LE BON, 2005, p. 29).

Essa longa citação revela que para o autor, na massa, o indivíduo adquire qualidades ou características que não possuía antes. Isso se dá em função do poder e da desinibição dos instintos proporcionado por estar em um grupo onde há uma superioridade numérica e um sentimento de anonimato, do "contágio" de comportamentos, ações e sentimento de um membro do grupo para outro, e da sugestionabilidade, onde o indivíduo age como alguém 
hipnotizado, abrindo mão do controle consciente de seus atos e se deixando conduzir pela sugestão do líder.

\begin{abstract}
Vemos então o desaparecimento da personalidade consciente, a predominância da personalidade inconsciente, a modificação por meio da sugestão e do contágio de sentimentos e idéias numa direção idêntica, a tendência a transformar imediatamente as idéias sugeridas em atos, estas, vemos, são as características principais do indivíduo que faz parte de um grupo. Ele não é mais ele mesmo, mas transformou-se num autômato que deixou de ser dirigido pela sua vontade. (LE BON, 2005, p. 32).
\end{abstract}

Nesse trecho, ficam evidentes quais são as várias características apresentadas pelos indivíduos, para Le Bon, quando agrupados em uma massa: as ações e idéias se propagam através de sugestão e contágio, e os indivíduos passam, então, a manifestar certa homogeneidade em seu comportamento e em seu funcionamento psíquico, tendendo a passar de forma imediata à ação, sem reflexão, com os indivíduos deixando de lado o interesse pessoal em função de um interesse coletivo ou de um objetivo coletivamente determinado.

Para Le Bon, há uma regressão do indivíduo no grupo, pois este abandona o controle consciente de sua personalidade, funciona ao sabor de seus instintos inconscientes, tem sua capacidade intelectual diminuída. Em um grupo, os indivíduos se comportam de forma impulsiva, instável e manipulável. 
Constantemente errante devido aos limites da inconsciência, submetida a todas as sugestões, animada pela violência de sentimentos própria dos seres que não podem apelar a influências racionais, desprovida de sentido crítico, a massa não pode senão manifestar uma credulidade excessiva. (LE BON, 2005, p. 38).

Há que se entender o sentido do termo inconsciente para Le Bon: diferente do sentido postulado por Freud, que é pessoal, refere-se a crenças e costumes de uma raça, sendo um inconsciente cujo conteúdo é coletivo e hereditário.

Assim, para o autor, o conceito de "alma da raça" tem importância capital na explicação do comportamento do indivíduo, tanto isolado quanto em coletivos, bem como do comportamento da massa como um todo:

Nossos atos conscientes derivam de um substrato inconsciente, formado sobre tudo por influências hereditárias. Este substrato encerra os inúmeros resíduos ancestrais que constituem a alma da raça. Por trás das causas manifestas de nossos atos se encontram causas secretas ignorados por nós mesmos. (LE BON, 2005, p. 30).

Para Le Bon, há dois tipos de idéias ou crenças que movem as massas: as fixas ou duradouras, que são em grande parte determinadas pela "alma da raça", e as "idéias móveis", que são opiniões ou idéias de duração efêmera, sendo exemplo destas as teorias que originam determinados movimentos nas artes ou na literatura, e que mudam ao longo do tempo. Disso decorre que as massas tendem a um conservadorismo, e não a uma 
mobilidade de idéias, como parece, pois ocorrem mudanças somente nas idéias móveis, havendo uma permanência das idéias fixas e da alma da raça.

As revoluções ou mudanças bruscas provocadas pela ou com a participação da massa na verdade não passariam de mudanças superficiais (de denominação, de aparência) para que as coisas continuem iguais. $\mathrm{O}$ autor cita como exemplo, em vários momentos, a Revolução Francesa, que segundo ele teria usado os mesmos mecanismos absolutistas e autoritários que dizia querer superar.

[...] representa um desconhecimento da psicologia das massas acreditar que nelas existe um predomínio dos instintos revolucionários. São tão somente suas violências que induzem a um erro a esse respeito. As explosões de rebelião e destruição são sempre muito efêmeras. [As massas] Em grande medida, estão regidas pelo inconsciente e submetidas, como consequência, à influência de heranças seculares, e não se mostram senão como extremamente conservadoras. Abandonadas a si mesmas, vêse muito rapidamente como se cansam de suas desordens e dirigem-se instintivamente à servidão. Os jacobinos mais ferozes e intratáveis aclamaram energicamente a Bonaparte, quando este suprimiu todas as liberdades e fez sentir sua dura mão de ferro. (LE BON, 2005, p. 47).

No caso de mudanças lentas nas idéias fixas, algumas revoluções representariam a negação final de um sistema de valores, sociedade ou idéia que já foi superado por aquela sociedade, mas cujos costumes não permitem abandoná-lo por completo. O advento das 
massas em uma determinada civilização representa assim um sinal de sua debilidade e de sua dissolução final:

Até agora, o papel mais claro desempenhado pelas massas consiste nas grandes destruições de civilizações envelhecidas. A história ensina que no momento em que as forças morais, estrutura de toda uma sociedade, deixaram de atuar, a dissolução final é efetuada por essas multidões inconscientes e brutais, classificadas com justiça como bárbaras. As civilizações foram criadas e guiadas, até agora, por uma reduzida aristocracia intelectual, jamais pela massa que não tem poder senão para destruir. Seu domínio representa sempre uma fase de desordem. Uma civilização implica em regras fixas, uma disciplina, o trânsito do instintivo para o racional, previsão de futuro, um grau elevado de cultura, condições completamente inacessíveis para as massas, abandonadas a si mesmas. Por seu poder exclusivamente destrutivo, atuam como aqueles micróbios que ativam a dissolução dos corpos debilitados ou dos cadáveres. Quando o edifício de uma civilização está carcomido, as massas provocam sua queda. Seu papel se põe, então, de manifesto. Durante um instante, a força cega do número se converte na única filosofia da história. (LE BON, 2005, p. 22).

Durante todo o desenvolvimento do texto, o autor deixa entrever uma valorização negativa da participação na massa. Para ele, mesmo indivíduos de reconhecida capacidade intelectual, quando em grupos como um júri de audiências judiciais ou reuniões parlamentares, apresentam um comportamento impulsivo, regredido, pouco racional, 
semelhante ao funcionamento mental de um selvagem ou de uma criança, ou de um indivíduo hipnotizado. Assim, a participação na massa sempre vem acompanhada de um rebaixamento nas capacidades e faculdades intelectuais, ainda que possa trazer alguns ganhos morais.

Essa colocação em comum de qualidades correntes nos explica porque as massas não podem realizar atos que exigem uma elevada inteligência. As decisões de interesse geral tomadas por uma assembléia de homens distintos, mas de diferentes especialidades, não são sensivelmente superiores às que adotaria uma reunião de imbecis. Tão somente podem associar, de fato, aquelas qualidades medíocres que todo mundo possui. As massas não acumulam inteligência, mas a mediocridade. (LE BON, 2005, p. 31).

Segundo Le Bon, em função de seu simplismo e da tendência a aceitar ou rechaçar idéias em bloco, sem reflexão, a massa pensa por imagens, por analogia e por associação simples, a partir de conclusões tiradas de casos concretos e únicos, as quais generaliza para outras situações. Assim, saber conquistar a imaginação das massas, trabalhando seus sentimentos e suas fantasias, consiste em um item essencial para mantê-las sob influência e governá-las.

Na história, a aparência tem desempenhado sempre um papel muito mais importante que a realidade. [...] As massas, ao não poderem pensar mais do que por imagens, não se deixam impressionar senão por imagens. [...] Por isso, as representações teatrais, que mostram a imagem em sua forma 
mais original, possuem sempre uma enorme influência. Pão e espetáculo constituíam, em seu tempo, o ideal de felicidade para a plebe romana. E este ideal variou pouco através das épocas. [...] Creio que este constitui um dos mais notáveis índices do estado mental das massas e, sobretudo, da facilidade com que são sugestionadas. [...] Sobre a imaginação popular se fundamentam o poder dos conquistadores e a força dos estados. Atuando sobre ela se arrasta a massa. (LE BON, 2005, p. 55).

Como tendem a um conservadorismo, as massas também se mostram autoritárias e intolerantes. Não toleram questionamentos ou discussões, por exemplo, e tão logo aceitam como verdadeira uma idéia, voltam-se contra toda possibilidade de discussão ou discordância. Além disso, o grupo tem uma afinidade com a força. Antes de qualquer coisa, o grupo tem consciência de sua própria força, proporcionada pela superioridade numérica, comparado com a força que teriam se estivessem sozinhos. É intolerante com a fraqueza, e exige que seus líderes sejam fortes. O grupo deseja seguir seu líder, respeita a autoridade, quer ser dirigido e temer quem está na direção.

$\mathrm{O}$ autoritarismo e a intolerância constituem para as massas sentimentos muito claros, que suportam tão facilmente quanto praticam. Respeitam a força e não lhes impressiona a bondade, considerada simplesmente como uma forma de debilidade. Suas simpatias jamais são dirigidas aos chefes paternais, mas aos tiranos que a tenham dominado vigorosamente. [...] Se gostam de pisotear o déspota caído, é porque ao perder sua força, ele é incluído na categoria dos débeis, a quem se deprecia e não se teme. O tipo de herói querido pelas massas sempre terá a estrutura de um César. Sua 
pompa os seduz, sua autoridade os intimida e seu sabre os atemoriza. Disposta sempre a sublevar-se contra uma autoridade débil, a massa se inclina servilmente ante uma autoridade forte. (LE BON, 2005, p. 46).

Para Le Bon, os indivíduos, assim que se juntam, se colocam instintivamente sob as ordens de um chefe, como em uma manada. Se por um lado o grupo necessita de um líder, procurando-o quando não o tem, por outro lado, o líder deve ter certas características pessoais que o habilitam a assumir essa posição frente a um grupo. Entre essas qualidades, o líder deve ser forte e colocar suas idéias de forma contundente, deve demonstrar fé intensa na idéia que defende, sendo "tomado" por esta, para que o processo de sugestão e contágio horizontal possa ser eficaz, bem como possuir prestígio frente aos participantes do grupo.

Geralmente, os condutores das massas não são homens de pensamento, mas de ação. [...] Por mais absurda que seja a idéia que defendam ou a finalidade que perseguem, todo arrazoamento se choca contra sua convicção. O desprezo e as perseguições não fazem senão excitar-lhes mais. Sacrificam tudo, seu interesse pessoal, sua família. Inclusive se anula neles seu instinto de autopreservação, até o ponto de que a única recompensa que solicitam é o martírio. A intensidade de sua fé confere às suas palavras um grande poder sugestivo. A multidão escuta sempre ao homem dotado de forte vontade. Já que os indivíduos reunidos em massa perderam toda a vontade, se voltam instintivamente àquele que a possui. (LE BON, 2005, p. 90). 
Prestígio é o "poder misterioso" que faz com que um indivíduo seja admirado e seguido, uma espécie de fascinação que o líder ou idéias exercem sobre o espírito dos indivíduos, que paralisam suas faculdades críticas e os enchem de respeito por aquele a quem seguem. $\mathrm{O}$ autor classifica as formas de prestígio em duas categorias: o pessoal e o adquirido. O primeiro diz respeito à capacidade de um indivíduo de atrair os outros mediante qualidades intrínsecas à sua pessoa, sendo representantes dos possuidores desse tipo de prestígio líderes como Jesus e Maomé. O segundo tipo tem relação com o reconhecimento e admiração decorrentes da ocupação de uma posição social, de bens materiais ou títulos, sendo exemplo desse tipo de prestígio aquele possuído por um magistrado ou por um militar usando farda.

Para o autor, a existência do grupo está intimamente ligada à figura do líder, que assume um papel essencial na formação e na manutenção da massa. Para que o líder consiga "criar fé" (LE BON, 2005, p. 90) em seus seguidores, no entanto, é necessário que a idéia não se afaste muito das idéias ou crenças apresentadas pela média dos indivíduos: caso contrário, não haveria adesão dos mesmos à massa. Esse é outro aspecto do conservadorismo da massa: ela pede por idéias e objetivos que estejam de acordo com a alma da raça, com as crenças fixas de sua época, com as tradições, opiniões e costumes que compõem seu inconsciente e determinam seu comportamento.

O autor pontua que alguns indivíduos, aos quais vai considerar como psicólogos natos, têm um conhecimento instintivo acerca do modo de funcionamento da alma da massa, sendo assim hábeis em conduzi-las e se tornando facilmente seus amos. Curiosamente, Le Bon descreve, já em 1895, a existência de processos que mais tarde vão ser novamente enfocados por Adorno ao se estudar as sociedades modernas, como a adesão ao pensamento em bloco e a ausência de reflexão por parte da massa, além 
da presença de uma diversão descompromissada, que substitui o pensamento e a reflexão. Cabe notar, no entanto, que para Le Bon, esses fenômenos ocorrem por que a massa, por sua própria natureza, pede por isso. Tal análise coloca em segundo plano os determinantes sociais do comportamento, bem como os mecanismos psicológicos envolvidos, que induzem o indivíduo, sozinho ou agrupado, a conduzir-se dessa forma. Tampouco se consideram as implicações em termos de instrumentalização e manipulação desse comportamento no sentido de manter o todo social.

Nesse sentido, concordamos com a crítica apresentada por Freud ao pensamento de Le Bon, qual seja, de que contempla uma descrição das características apresentadas pelas massas, bem como acerca do comportamento dos indivíduos que a compõem, sem, no entanto, haver uma discussão aprofundada dos mecanismos psicológicos envolvidos, nem a explicação do que motivaria os indivíduos a se juntarem em grupos, ou se colocarem sob a influência de um líder.

\subsection{Freud e a psicologia de grupo}

Partindo de uma discussão desse trabalho de Le Bon, Freud procura desenvolver sua teoria acerca do surgimento e do funcionamento dos grupos sob um enfoque psicodinâmico, que privilegia a compreensão do grupo como um reflexo do funcionamento psicológico dos indivíduos que dele participam. A obra na qual Freud desenvolveu mais detalhadamente sua teoria de grupo, "Psicologia de Grupo e Análise do Ego", data de 1921.

Freud concorda com a descrição de Le Bon acerca das características apresentadas pelos indivíduos quando em grupo: estes apresentariam um comportamento que poderia ser 
denominado de regredido, caracterizado pela influenciabilidade de seus comportamentos, pelo desaparecimento das diferenças individuais marcantes, a presença de um sentimento de poder coletivo, uma desinibição instintual, a propensão à ação violenta e à irracionalidade.

Se Freud concorda com a descrição feita por Le Bon, ele tem, no entanto, uma opinião mais positiva que este último sobre o funcionamento dos grupos. O autor vai diferenciar massa ou multidão de grupos mais organizados, reportando a estes últimos uma grande capacidade criativa e intelectual, exemplificadas nos grandes feitos e realizações humanas coletivas, como a linguagem e a cultura. Além disso, a participação em grupos organizados pode contribuir para diminuir ou temporariamente fazer desaparecerem as neuroses (FREUD, 1996).

O autor também discorda de Le Bon quanto ao que motiva o surgimento de um grupo e ao que o mantém unido: não seria um pretenso instinto de manada, mas vínculos libidinais formados entre os indivíduos. Assim, entende que os indivíduos se juntam em grupos em função de necessidades colocadas pelo funcionamento psíquico de cada um dos seus participantes.

A necessidade de ficar junto com os outros se explica pela tendência da libido de agregar os indivíduos em unidades cada vez maiores. A tendência para a formação de grupos é uma continuação do "caráter multicelular" dos organismos superiores, que sob a influência de Eros se juntam em unidades cada vez mais extensas.

Outro fator que impeliu o homem a se organizar em grupos foi o trabalho: desde que percebeu que precisava lidar com as forças da natureza, a relação com outros homens passou a não lhe ser indiferente, isto é, a ação de outros homens podia ajudá-lo ou atrapalhá-lo em sua busca pela sobrevivência. Com isso, ele procurou se agrupar em 
unidades cada vez maiores, criando regras de convivência entre si, inventando assim a vida em sociedade e a própria civilização (FREUD, 1996b).

Dessa forma, os homens se juntaram em grupos sob a ação de Eros e Ananke - o Amor e a Necessidade, que se tornaram os pais da humanidade (FREUD, 1996b).

Freud postula que em todos os casos onde há colaboração ou trabalho em conjunto, há a formação de laços libidinais entre as pessoas, laços esses que perduram mesmo após terem sido alcançados os objetivos da colaboração mútua:

[...] a experiência demonstrou que, nos casos de colaboração, se formam regularmente laços libidinais entre os companheiros de trabalho, laços que prolongam e solidificam a relação entre eles até um ponto além do que é simplesmente lucrativo. (FREUD, 1996, p. 113).

Freud também se depara com a questão da relação indivíduo/grupo e o conflito entre a liberdade e a submissão da vontade individual ao coletivo, esperando para o futuro uma acomodação positiva e equilibrada entre essas duas premências. Para o autor, há uma disputa interna em cada indivíduo, com relação à distribuição de catexias libidinais entre o desejo individual e o que é exigido pelo grupo:

Trata-se de uma luta dentro da economia da libido, comparável àquela referente à distribuição da libido entre o ego e os objetos, admitindo uma acomodação final no indivíduo, tal como, pode-se esperar, também o fará no futuro da civilização, por mais que atualmente essa civilização possa oprimir a vida do indivíduo. (FREUD, 1996b, p. 143). 
Se os homens, por força de Eros, são impelidos a se unirem em grupos, para o autor, isso não se deve à existência de um possível instinto gregário, mas à formação de vínculos libidinais entre os participantes desses grupos, vínculos esses que dependem dos laços de cada um dos participantes com o líder, numa atualização ou revivescência da horda primeva. Para Freud, o ser humano é um ser de horda:

Todos os membros devem ser iguais uns aos outros, mas todos querem ser dirigidos por uma só pessoa. Muitos iguais, que podem identificar-se uns com os outros, e uma pessoa isolada, superior a todos eles: essa é a situação que vemos realizada nos grupos capazes de subsistir. Ousemos, então, corrigir o pronunciamento de Trotter de que o homem é um animal gregário, e asseverar ser ele de preferência um animal de horda, uma criatura individual numa horda conduzida por um chefe. (FREUD, 1996, p. 131).

Assim, o grupo se constitui de "um certo número de indivíduos que colocaram um só e mesmo objeto no lugar de seu ideal de ego e, consequentemente, se identificaram uns com os outros em seu ego" (FREUD, 1996, p.126).

Os vínculos libidinais que levam à formação de um grupo, e que sustentam sua existência, são os impulsos sexuais inibidos em sua finalidade.

No funcionamento de um grupo, estão em atuação, em seus membros, os mecanismos psicológicos da identificação, da idealização, da regressão e do narcisismo. 
As características apresentadas pelo indivíduo no grupo indicam uma regressão a um estágio de funcionamento psíquico anterior. Para o autor, essa regressão é a responsável por certas características dos grupos, como a diminuição da capacidade intelectual, o descontrole emocional, a tendência à atuação, com a transformação de qualquer emoção em ação imediata e em geral violenta, em função da diminuição da capacidade crítica dos indivíduos participantes. Assim, para Freud, não há o surgimento de novas características nos indivíduos que compõem a massa, como postula Le Bon, mas a emergência de características que os indivíduos já possuem, possibilitada pela diminuição da repressão.

Uma das regressões que podem ser observadas num grupo é a da escolha de objeto para a identificação. A identificação consiste na mais antiga expressão de um vínculo emocional com outro indivíduo. É anterior à formação edípica e anterior inclusive à própria eleição de objeto sexual. A identificação pode ser positiva ou negativa. No primeiro caso, há um enriquecimento da personalidade, pois o objeto com o qual o indivíduo se identifica é assimilado/ incorporado, trazendo assim novas qualidades para o mundo interno do indivíduo. A identificação positiva é essencial para o desenvolvimento do indivíduo, sendo parte do processo de constituição da identidade. Segundo Freud (1996, p. 139), "cada indivíduo faz parte de vários grupos, está ligado por identificação de vários lados, e constitui seu ideal de ego segundo os mais diversos modelos."

Já no segundo caso, o objeto com o qual o indivíduo se identifica é colocado no lugar de um objeto interno, fazendo com que o indivíduo perca as qualidades desse objeto, em detrimento do objeto que tomou seu lugar.

No caso de um grupo, a identificação ocorre tanto com o líder quanto com os outros participantes. Com o líder, a identificação se dá com a colocação deste no lugar do ideal de ego do indivíduo, em função do líder apresentar alguma ou algumas características que o 
assemelhem a algum ideal de ego não alcançado do sujeito, que agora pode ser satisfeito de maneira indireta. Justamente por isso, a escolha do líder envolve mecanismos de idealização, que consiste em uma transferência parcial da libido narcisista do ego para o objeto, numa situação semelhante à hipnose ou ao estar amando.

Cabe salientar que o líder de um grupo não necessariamente precisa ser uma pessoa, podendo ser substituído por uma idéia, uma abstração, ou um desejo. Freud vai chamar estes últimos de "líderes secundários", e usa os grupos religiosos como exemplos típicos de grupos dirigidos por idéias.

Com a idealização e o investimento narcísico, o líder passa a ser visto como detentor de um valor e de qualidades superiores, sendo engrandecido e levado à perfeição. Diante de tal líder, o seguidor se comporta de forma submissa, humilde e servil, apresentando uma diminuição da iniciativa própria e de sua capacidade crítica:

\footnotetext{
Ao mesmo tempo dessa 'devoção' do ego ao objeto, a qual não pode mais ser distinguida de uma devoção sublimada a uma idéia abstrata, as funções atribuídas ao ideal do ego deixam inteiramente de funcionar. A crítica exercida por essa instância silencia; tudo que o objeto faz e pede é correto e inocente. A consciência não se aplica a nada que seja feito por amor do objeto; na cegueira do amor, a falta de piedade é levada até o diapasão do crime. (FREUD, 1996, p. 123).
}

Com a colocação do líder no lugar do ideal de ego, o indivíduo abre mão de suas características pessoais em função das que reporta ao líder. Isso explica a influenciabilidade e a homogeneidade presentes no comportamento dos participantes de um grupo. 
Há que se observar que alguns indivíduos são mais suscetíveis a esse processo, em virtude de seu desenvolvimento psicológico insuficiente. Para esses sujeitos, a diferenciação entre ego e ideal de ego não foi satisfatoriamente alcançada, e o líder tem apenas que dar uma sensação de força e de maior liberdade libidinal para ser colocado nesse lugar.

\footnotetext{
Em muitos indivíduos, a separação entre o ego e o ideal de ego não se acha muito avançada e os dois ainda coincidem facilmente; o ego amiúde preservou sua primitiva auto-complacência narcisista. A seleção do líder é muitíssimo facilitada por essa circunstância. Com frequência precisa apenas possuir as qualidades típicas dos indivíduos interessados sob uma forma pura, clara e particularmente acentuada, necessitando somente fornecer uma impressão de maior força e de mais liberdade de libido. Nesse caso, a necessidade de um chefe forte frequentemente o encontrará a meio caminho, e o investirá de uma predominância que de outro modo talvez não pudesse reivindicar. Os outros membros do grupo, cujo ideal de ego salvo isso, não se haveria corporificado em sua pessoa sem alguma correção, são então arrastados com os demais por 'sugestão', isto é, por meio da identificação. (FREUD, 1996, p. 139).
}

Assim, o líder ocupa uma posição essencial para a formação e a manutenção de um grupo. Ele deve amar a todos igualmente, ou melhor, deve passar a sensação de que ama a todos igualmente, porque ele pode ser absolutamente narcisista e não amar ninguém. Ao passar a sensação de que ama a todos, o líder os coloca em uma posição de igualdade uns 
com os outros, o que, somado com a colocação de um mesmo objeto no lugar do ideal de ego, abre o caminho para uma identificação horizontal entre os participantes do grupo.

A força do vínculo emocional - a identificação - partilhado pelos participantes do grupo se traduz em uma sensação de união e de força. As ações são realizadas coletivamente, de acordo com vontades comuns e não vontades isoladas. Em um grupo, uma idéia só se transforma em ato quando é percebida sua difusão geral.

Há que se observar que quando há rompimento desses laços libidinais, o grupo deixa de existir, os indivíduos passam a preocupar-se apenas consigo mesmo, o que cria um sentimento de pânico e de desagregação.

A identificação, como expressão mais remota de um vínculo afetivo, é ambivalente desde o início: pode rapidamente passar de um afeto cuja tonalidade é positiva para um desejo de afastamento ou aversão. Assim, num grupo, os vínculos afetivos formados tanto com o líder quanto com os outros participantes, são ambivalentes.

Considerando que o grupo é uma revivescência da horda primeva, a capacidade e o desejo de estar em grupo, que Freud vai chamar de sentimento comunal ou sentimento social, tem seu protótipo em uma dupla inversão: o líder remete ao pai da horda primeva, que era igualmente temido por todos os filhos; para sobreviver frente a uma personalidade tão forte e perigosa, os indivíduos têm que abrir mão de sua própria vontade e inverter o temor e a raiva em amor. Já para com os outros participantes do grupo, o vínculo deriva de uma inveja original, um sentimento hostil relacionado ao medo da perda do objeto ou o ciúme em dividi-lo com aqueles que lhe são iguais. A inversão em um "espírito de grupo" cumpre a função de igualar os indivíduos uns aos outros, não permitindo que nenhum tenha mais do que o outro. 
O que posteriormente aparece na sociedade sob a forma de Gemeingeist, esprit de corps, 'espírito de grupo', etc. não desmente a sua derivação do que foi originalmente inveja. Ninguém deve querer salientar-se, todos devem ser o mesmo e ter o mesmo. [...] Essa exigência de igualdade é a raiz da consciência social e do senso de dever. (FREUD, 1996, p. 130).

Cabe ainda comentar a função da libido narcisista na criação e na manutenção dos vínculos libidinais presentes num grupo: o narcisismo envolvido na formação do grupo tem sua origem no investimento narcísico na figura do líder, com a sua colocação no lugar do ideal de ego. Além disso, há ainda uma limitação do narcisismo individual decorrente da identificação com os outros participantes do grupo, o que tem como consequência uma maior tolerância para com as diferenças individuais e uma sensação de uniformidade entre os participantes.

O narcisismo e a identificação também explicam a intolerância para com os que não participam do grupo ou para com os outros grupos (exogrupos), posto que a aversão pelo diferente é apenas uma expressão do amor a si mesmo; bem como o fato de que os indivíduos colocam sua autopreservação em risco em alguns atos do grupo: o fato da libido não estar mais investida no ego faz com que este possa ser colocado em risco por amor ao ideal de ego.

Se são os laços libidinais e a colocação de um mesmo objeto no lugar de ideal de ego que explica o surgimento e a manutenção de um grupo, há que se observar que há uma diferença considerável no funcionamento de um grupo não organizado (massa, multidão) para um grupo organizado. 
Para Freud, nos grupos organizados, a regressão pode ser em grande medida controlada. Diferenciando o funcionamento da massa dos de grupos organizados, o autor pontua que a primeira atua de uma forma mais primária, com claros sinais de regressão nos indivíduos que fazem parte desses grupos, com perdas nos aspectos intelectuais, na capacidade crítica, e no controle afetivo.

Já os grupos organizados, que são estáveis e que se acham corporificados nas instituições da sociedade, adquirem secundariamente as características de um indivíduo, quais sejam, continuidade, autoconsciência, tradição e costumes próprios, funções e posições particulares, diferenciação e afastamento em relação aos rivais.

Ao adquirir as características do funcionamento individual, os aspectos negativos e regredidos do funcionamento de um grupo são atenuados, potencializando os aspectos positivos do estar em grupo, obtendo ganhos tanto para o indivíduo que dele participa quanto para a sociedade como um todo.

Uma das principais críticas às teorias de funcionamento de grupo postuladas por Freud remetem ao fato de que o autor constrói uma explicação eminentemente psicológica para o funcionamento dos grupos, desconsiderando assim os determinantes sociais que influenciam a constituição dos grupos.

\subsection{Ortega y Gasset e a rebelião das massas}

Partindo de premissas semelhantes aos colocados por Le Bon, cerca de uma década depois de Freud construir sua teoria a respeito do funcionamento dos grupos, um outro autor estudado, Ortega y Gasset, vai se posicionar de forma bastante diferente com relação 
ao funcionamento dos mesmos. Analisando os países ocidentais de economia desenvolvida nos anos 30 do século passado, chega à conclusão de que vivemos em um momento que ele vai nomear de período da "revolução das massas".

O autor comunga de uma visão evolucionista das sociedades e da história, e vai pontuar as mudanças ocorridas na sociedade, que levaram ao surgimento do que ele chama de "homem-massa".

Ortega y Gasset parte do princípio de que o homem e sua forma específica de organização social é moldada pelo mundo, pelo período histórico em que se vive. As formas históricas de organização e funcionamento que cada sociedade assume, induzem o homem a se comportar de uma maneira ou de outra. Dentro dessa concepção, assume especial importância o conceito de "opinião pública", que exprime o conjunto de valores e crenças partilhados em uma dada sociedade, e que tem um papel preponderante e essencial na formação do indivíduo e no controle de seu comportamento, através da pressão social.

Outro pressuposto do autor, que tem relação com o surgimento dos grupos, é o fato de que o homem, por natureza, necessita de uma instância superior que o governe, pois possui um "instinto irreprimível de hierarquia" (ORTEGA Y GASSET, 2007, p. 274). Dentro da concepção do autor, a posição de mando e a de obediência são naturais, e existem desde os primórdios da humanidade. Aliada à necessidade de mando e obediência, os indivíduos também sentem um imperativo de serem úteis para algo. O desejo de ser útil, de se dedicar a alguma tarefa, seja ela simples ou gloriosa, é inerente ao ser humano, que nem sempre tem claro qual deve ser essa tarefa, necessitando de alguém que o conduza na definição desse objetivo. 
A maior parte dos homens não tem opinião, e é preciso que esta venha de fora sob pressão, como o lubrificante entra nas máquinas. Por isso é preciso que o espírito - seja qual for - tenha poder e o exerça, para que as pessoas que não opinam - e são a maioria - opinem. Sem opiniões, a convivência humana seria o caos; menos ainda: o nada histórico. Sem opiniões, a vida do homem careceria de arquitetura, de organicidade. Por isso, sem um poder espiritual, sem alguém que mande, e na medida em que isso faltar, reinará o caos na humanidade. (ORTEGA Y GASSET, 2007, p. 165, itálicos no original).

Em cada período histórico, as idéias, valores e opiniões vigentes em determinada sociedade são fruto da predominância das idéias do indivíduo ou grupo que detém o poder. Assim, esse grupo é responsável pela formação, naquele determinado período histórico, da opinião pública. O mando, como exercício de autoridade natural e desejado por todos, só pode ser exercido tendo por base a opinião pública.

Pois bem: essa relação estável e normal entre homens que se chama "mando" nunca repousa na força, mas é justamente o inverso, porque é o fato de um homem ou um grupo de homens exercer o mando que põe à sua disposição esse aparato ou máquina social que se chama "força". [...] O mando é exercício normal de autoridade, o qual se fundamenta sempre na opinião pública - sempre, hoje ou a dez mil anos, entre os ingleses ou entre os botocudos. (ORTEGA Y GASSET, 2007, p. 163, itálicos no original). 
A divisão natural dos homens em aqueles que têm opinião e por isso devem governar, e os que não têm, e por isso devem ser guiados, gera por si só uma separação dos indivíduos em duas categorias distintas: os grupos ou minorias "especiais" e a massa, ou multidão. Há uma diferença essencial entre os grupos especiais e a massa.

O homem excelente, ou aristocrata, é aquele que busca uma certa nobreza em seu pensar e em seu agir, levando uma vida dedicada a um ideal maior que ele, à disciplina e à busca da perfeição. Caracteriza-se por colocar-se a serviço de uma norma superior, exigir muito de si mesmo, buscar superar-se. A vida nobre é caracterizada pela servidão, pois o homem excelente busca servir a algo superior a ele.

Esses homens, quando se juntam, formam os grupos ou minorias especiais, agrupamentos cuja característica principal é que são formados por sujeitos diferentes, ou seja, individualizados, diferençados uns dos outros, singulares, os quais comungam as idéias e valores uns dos outros, mas cuja semelhança com aqueles que participam do mesmo grupo é secundária, consiste muitas vezes em não coincidir com a massa.

Já os homens vulgares, que são aqueles que compõem a massa, se caracterizam por carecerem de uma identidade própria e de uma interioridade, por não terem opinião própria, pensarem por estereótipos, por serem inertes e passivos.

O "homem-massa", que é como Ortega y Gasset vai nomear esse indivíduo, é aquele cuja vida carece de projeto, que se deixa levar pelo seu desejo imediato, que não consegue refletir sobre sua vida. O homem-massa vive de uma forma esvaziada e instintual, como as crianças e os primitivos, e não se angustia com o fato de ser massa, isto é, de ser absolutamente igual e homogêneo aos outros, e não ter idéias próprias ou mesmo uma individuação. Mais do que isso, o homem massa proclama com orgulho o direito de ser vulgar: 
Não é que o homem-massa seja idiota. Ao contrário, o atual é mais rápido, tem mais capacidade intelectiva que o de qualquer outra época. Mas essa capacidade não lhe serve de nada; a rigor, a vaga sensação de possuí-la só serve para ele fechar-se ainda mais em si, e não para usá-la. Consagra definitivamente a coleção de tópicos, preconceitos, pedaços de idéias ou, simplesmente, palavras vazias que ao acaso foi amontoando em seu interior, e, com uma audácia que só se explica pela ignorância, quer impôlos em qualquer lugar. Era isso que no primeiro capítulo eu enunciava como característico de nossa época: não é que o vulgo pense que é excepcional e não vulgar, mas sim que o vulgar proclama e impõe o direito da vulgaridade, ou a vulgaridade como um direito. (ORTEGA Y GASSET, 2007, p. 103).

A massa, ao contrário dos grupos, se forma por junção desses sujeitos sem individualidade, iguais entre si, homogêneos.

O que provoca a formação da massa é o instinto de hierarquia que os homens possuem. Dessa forma, é natural que a massa siga aquele ou aqueles que têm capacidade de liderança, visto que os participantes da massa precisam de alguém que os dirijam, que identifiquem para eles quais devem ser seus objetivos, e que os incitem a pensar, posto que não têm essa capacidade por si mesmos, precisando ser guiados pelos que são mais capazes do que eles. Isso se dá nas relações estabelecidas dentro de uma dada sociedade, e se repete nas relações estabelecidas entre diferentes sociedades, entre diferentes nações.

Para o autor, massa e minorias sempre existiram e sempre existirão, a diferença é que em nossa época, a massa está em todos os lugares, assume o primeiro plano na 
convivência social, e dirige a opinião pública - algo que antes era feito pelos grupos minoritários.

O ponto positivo da massa estar em todos os lugares é que isso indica uma "subida do nível histórico", isto é, que a massa passou a ter acesso aos lugares que antes eram reservados para as minorias. Não só isso, mas aqueles que compõem a massa passaram a ter acesso a conhecimento, bens de consumo, serviços, etc,... antes reservados para os pertencentes à nobreza ou à aristocracia. O padrão de vida do homem médio de hoje é composto por elementos que em épocas anteriores caracterizavam o modo de vida de uma minoria, o que o autor vai considerar uma "elevação no nível histórico", haja vista que o nível de cada período histórico é dado pelo nível de vida do homem médio.

O advento das massas também tem a vantagem de poder livrar a sociedade das instituições mortas e anacrônicas, ao renovar o espaço público com sua criatividade e sua tendência à ação.

Por outro lado, se as massas apresentam alguns aspectos positivos, apresentam também alguns aspectos negativos. O que pode ser um ponto positivo, também é um risco: as massas rejeitam o mundo das idéias, e preferem partir para a ação. O hábito de não raciocinar, de não refletir sobre as razões de suas ações e opções, de não discutir e opinar, deixa somente um caminho aberto para o participante da massa - passar à ação direta, sem reflexão.

A ação direta, irrefletida, eleva a violência à primeira opção de ação dos indivíduos. Isso leva a um retrocesso e ao retorno à barbárie, cada vez mais presente nas sociedades modernas. Para o autor, o nível de barbárie das sociedades modernas é tão grande, que sequer os conhecimentos e avanços científicos podem garantir um progresso intelectual e social. 
Outro aspecto negativo na massa atual é que o indivíduo se dá o direito de permitir a livre expansão de seus desejos vitais, e os participantes da massa não querem mais se deixar guiar pelos grupos minoritários, a quem deveriam seguir:

Desse modo, nos encontramos com uma massa mais forte do que de nenhuma outra época, mas diferente da tradicional, fechada em si mesma, que não atende a nada e a ninguém, acreditando que se basta a si própria em suma: indócil. Se as coisas continuarem como até agora, a cada dia se notará mais em toda a Europa - e por sua influência, em todo o mundo que as massas são incapazes de se deixarem conduzir sob qualquer aspecto. Nas horas difíceis que estão chegando a nosso continente, é possível que, subitamente angustiadas, tenham um momento de boa vontade e aceitem a direção das minorias superiores, em assuntos de especial premência. Mas mesmo assim essa boa vontade fracassará. Porque a textura básica de sua alma é feita de hermetismo e indocilidade, porque lhes falta, por nascimento, a função de atender o que está além delas, sejam fatos ou pessoas. (ORTEGA Y GASSET, 2007, p. 98).

Além disso, a massa é ingrata, não reconhecendo os fatores que a levaram a um nível de vida maior, como a direção das minorias e os avanços trazidos pela ciência. A falta de reconhecimento da massa com relação aos fatores que possibilitaram um avanço em suas condições de existência leva a que a massa, na ânsia de reproduzir-se e continuar sua existência, tenda a destruir as próprias causas e meios de sua vida.

A massa odeia a convivência com tudo o que não lhe é semelhante, com tudo o que não é homogêneo como ela, tendendo a destruir e sufocar tudo o que lhe faz oposição, pois 
além de esvaziados e homogêneos, os indivíduos que participam da massa querem que os outros lhe sejam semelhantes, odiando tudo que é diferente. Assim, a massa

[...] tem a coragem de afirmar o direito da vulgaridade e o impõem em toda a parte. Como se diz nos Estados Unidos: ser diferente é indecente. A massa faz sucumbir tudo o que é diferente, egrégio, individual, qualificado e especial. Quem não for como todo mundo, quem não pensar como todo mundo correrá o risco de ser eliminado. (ORTEGA Y GASSET, 2007, p. 48, itálico no original).

As massas de nosso tempo se formaram primeiramente por causa do aumento numérico da população. Isso, aliado à migração do campo para a cidade, fez com que nas zonas urbanas a multidão passa a ocupar todos os espaços públicos.

Segundo o autor, o homem hoje não tem individualidade: a aglomeração das cidades grandes e a homogeneidade, a dependência que se tem do outro para sobrevivermos, faz com que o indivíduo abra mão de sua individualidade a favor de uma vida standard. Nossas sociedades se assemelham a

[...] uma prisão onde se amontoaram muito mais presos do que cabiam, nenhum deles podendo mover um braço ou uma perna por iniciativa própria, porque se chocaria com os corpos dos outros. Em tais circunstâncias, os movimentos têm que ser executados em conjunto, e até o ato de respirar deve ser executado no ritmo regular. [...] É impossível que a vida humana venha a ser moldada na das térmites, porque foi o chamado "individualismo" que enriqueceu o mundo e a todos no mundo, 
e foi essa riqueza que fez proliferar tão fabulosamente a planta humana. (ORTEGA Y GASSET, 2007, p. 29, itálico no original).

Ortega y Gasset também vai pontuar o impacto da Primeira Guerra Mundial na formação das massas modernas. Segundo o autor, até a guerra, era a Europa que cumpria o papel de liderar o mundo, de ser o grupo especial que o dirigia. Após, começaram a surgir dúvidas sobre quem manda, bem como vários países europeus mudaram sua política interna, deixando de intervir em outros países. Com isso, a Europa deixou de dar o exemplo de liderança, o que enfraqueceu não só o papel da Europa como liderança mundial, mas a falta de exemplo fez com que as lideranças internas também fossem enfraquecidas e colocadas em segundo plano pelas massas.

Outro fator importante para a formação das massas com as características que ela assume em nosso tempo foi o nível de avanço das sociedades ocidentais modernas. Esse avanço trouxe uma série de facilidades, bem como abundância de bens em excesso. Essa abundância de bens dá ao homem uma sensação de domínio e de senhorio, bem como de ausência de limites, causando uma deformação no caráter dos homens, degenerando-os. A ausência de limites e a sensação de senhorio reforçam a atuação do indivíduo no mundo de forma imediata, através da ação sem reflexão, bem como reforça sua tendência a não mais seguir a direção dada pelos grupos minoritários.

Assim, a chamada "revolução das massas" consiste na insubmissão das multidões à direção dos grupos minoritários especiais. Essa inversão de valores e papéis, que segundo o autor nunca havia acontecido antes, pode colocar em risco o progresso dos povos, posto que sem direção, não há como uma civilização sobreviver e avançar. 
Ademais, em nossas sociedades, a mentalidade do homem-massa não está circunscrita àqueles que efetivamente participam da massa, mas transformou-se em uma espécie de padrão social, um estado de espírito, um modo de ser presente em todas as classes sociais, caracterizado por sentir-se igual aos demais e estar satisfeito com este fato.

O exercício direto da democracia, em vez de ser um avanço, é considerado um retrocesso, o que o autor vai denominar de "hiperdemocracia". Nos sistemas de democracia liberal, a massa escolhe, através de eleição, um grupo minoritário com seu projeto de sociedade para conduzi-la. A democracia direta é inviável porque essa massa é incapaz de refletir, de propor um projeto de sociedade, enfim, de saber o que é melhor para si e caminhar sozinha nessa direção.

A democracia direta dá ao homem vulgar a impressão que ele tem a capacidade para decidir o que é melhor para si, tirando a decisão das mãos dos que são mais esclarecidos, que tem maior capacidade de compreender melhor a situação e guiar a massa na direção do que é melhor para ela.

Dessa forma, Ortega y Gasset apresenta uma visão evolucionária da história e da civilização, considerando que para o correto funcionamento de uma sociedade, grupo social nação ou mesmo um conjunto de nações, aqueles que possuem alguns diferenciais, o grupo de "homens excelentes", deve conduzir a massa, que é incapaz de dirigir-se por si própria.

Pode-se perceber nesse discurso a crença numa minoridade do indivíduo, que é incapaz de decidir, sem a orientação de uma minoria esclarecida, o que é melhor para sua própria vida. Ademais, percebe-se uma orientação conservadora no entendimento de Ortega y Gasset acerca do funcionamento dos grupos, com uma visão eminentemente negativista dos grupos e das massas. 
Apesar de ter escrito sua obra posteriormente à Freud, Ortega y Gasset não incorpora em sua análise o funcionamento da subjetividade individual, mesmo porque os homens comuns, que participam da massa, carecem de uma interioridade e de uma identidade própria.

\subsection{Adorno e uma compreensão crítica dos grupos}

Adorno explicita uma visão dialética sobre o funcionamento e o papel dos grupos dentro da sociedade capitalista, abarcando os movimentos sociais, considerando igualmente os aspectos sociológicos/objetivos e os psicológicos/subjetivos, utilizando para isso conceitos do marxismo e da psicanálise (ADORNO, 1986b; CARONE, 1991; CROCHIK, 1996, ROUANET, 1986). À semelhança de Freud, rompe com uma visão negativa da participação em coletivos, incluindo a participação dos indivíduos na massa, que inclusive poderia representar um potencial de resistência racional à dominação (ADORNO, 2006). Da mesma forma que Freud, utiliza um conceito amplo de grupo, que inclui grupos espontâneos e organizados, bem como abarca também as massas e multidões (CROCHIK, 2007).

Segundo Adorno, a tensão entre indivíduo e sociedade é o que origina os grupos: o homem não consegue se inserir imediatamente na totalidade social, necessitando de instâncias intermediárias. Portanto, os grupos são inerentes à existência da sociedade, e exercem a função de serem mediadores de concepções, atitudes e normas, se constituindo em espaço de interação entre o universal e o particular (HORKHEIMER; ADORNO, 1973). 
Na tensão entre o indivíduo e a sociedade, a divergência do universal e do particular implica, necessariamente, que o indivíduo não se insere de forma imediata na totalidade social mas através de instâncias intermediárias. Estas instâncias intermediárias são as que se encontram abrangidas pelo conceito de Grupo [...]. (HORKHEIMER; ADORNO, 1973, p. 61, itálico no original).

Para Adorno, apesar da funcionalidade e da necessidade de se definir o conceito grupo, há uma impossibilidade de significação e determinação unívoca, porquanto os grupos são construções sociais e, portanto, variam conforme a conformação social de cada período histórico. Assim, os grupos são constituídos em momentos históricos dados e, portanto, são determinados em grande parte pelo mundo social onde estão inseridos (HORKHEIMER; ADORNO, 1973).

A relação entre indivíduo e grupo é diferente se compararmos os chamados microgrupos com os grupos maiores, organizados de forma racional. Nos primeiros, há contato direto entre os homens, estes se identificam uns com os outros, com os quais têm uma experiência real e imediata e, consequentemente, se identificam com o grupo como um todo. Nesses grupos, o homem pode ter experiências de si mesmo, ao mesmo tempo em que está vinculado a outras pessoas, possibilitando a emergência de uma consciência autônoma, bem como de uma verdadeira solidariedade. Nos segundos, que possuem objetivos utilitários e racionalmente determinados, e muitas vezes heterônomos, e onde os vínculos de interesse preponderam sobre outros tipos de vínculo, os homens não se reconhecem, e a sensação de estranheza tem como consequência o esforço feito pelo indivíduo para se 
ajustar. Em nossa sociedade, são esses grupos que são mais importantes para a reprodução da vida dos indivíduos adultos, em detrimento dos grupos pequenos (HORKHEIMER; ADORNO, 1973).

Outrossim, no momento histórico em que vivemos hoje, os próprios grupos pequenos, com e nos quais o homem costumava se identificar, à semelhança das massas, estão integrados na lógica do todo, sendo instrumentalizados e exercendo seu papel de mediação subordinado ao mundo administrado, contribuindo para que o indivíduo seja imediatamente absorvido pela unidade maior, pelo todo societário (HORKHEIMER; ADORNO, 1973).

À semelhança dos autores anteriormente analisados, Adorno reconhece uma diferenciação entre o funcionamento de grupos mais organizados e das massas. Nestas últimas, o indivíduo tende a se comportar de forma irracional, apresentando comportamentos e sustentando interesses que com frequência são contrários aos seus interesses racionais, ou que muitas vezes atentam contra sua própria auto-preservação (HORKHEIMER; ADORNO, 1973).

Para o autor, no entanto, a facilidade para a formação das massas hoje não se dá simplesmente em função do aumento numérico da população, como postula Ortega y Gasset (2007), posto que o aumento das populações resulta no que o autor chama "multidões acidentais da grande cidade" (ADORNO, 2006, p. 171). A transformação dessas multidões acidentais em massa se deve à "atomização, a alienação e a impotência individual" (HORKHEIMER; ADORNO, 1973, p. 87) a que estão submetidos os indivíduos hoje, ou seja, a debilidade do ego dos indivíduos em nossas sociedades induzem à submissão e ao desejo de conformar-se na massa como forma de compensação para o que falta, do ponto de vista psicológico (HORKHEIMER; ADORNO, 1973). 
Cabe pontuar que, como vimos anteriormente, a debilidade do ego e a atomização dos indivíduos se deve a razões objetivas e socialmente construídas. Para Adorno, o que motiva a formação dos grupos são as condições objetivas de existência - nesse sentido, Adorno privilegia a compreensão freudiana da primeira tópica, de que os homens se agrupam em função da ação de Eros e de Ananke (o amor e a necessidade) e pontua que a teoria construída por Freud a respeito do funcionamento dos grupos viu no indivíduo o reflexo do todo social (ADORNO, 2006).

Vivemos numa sociedade autoritária, marcada pela ambivalência e pela contradição, e essas contradições se reproduzem tanto nos indivíduos quanto nas organizações e grupos que surgem nessa sociedade. Desta forma, na sociedade capitalista, onde a consciência está tomada, os sujeitos privilegiariam situações e relações onde pudessem se submeter, e o domínio totalitário não seria somente "imposto aos homens desde fora, mas também se prepara, simultaneamente, em seu próprio íntimo" (HORKHEIMER; ADORNO, 1973, p. $115)$.

O mesmo acontece com os grupos, que constituem uma possibilidade de protesto contra as injustiças e fornecem ao indivíduo uma possibilidade de vivência coletiva, identificação e solidariedade, mas também podem ser reprodutores do autoritarismo e da irracionalidade do sistema, podendo servir de meio para a dominação e alienação do homem, já que os grupos também sofrem a influência da cisão e da alienação da sociedade, que debilita a subjetividade do sujeito, e "a identificação, seja com o coletivo ou com a figura poderosa do chefe, oferece ao indivíduo um substituto psicológico para o que lhe falta na realidade" (HORKHEIMER; ADORNO, 1973, p. 87).

Quanto aos mecanismos psicológicos em atuação nas formações grupais, Adorno, aproximando-se de Freud (1996), vai destacar a natureza libidinal do vínculo entre os 
participantes, sublinhando o papel da identificação e do narcisismo, em especial na formação das massas em nossa sociedade. Para ele, o narcisismo coletivo e socializado, modificação do narcisismo individual, se apresenta nos grupos e nas massas, preservando a função auto-conservadora do ego, mas cindindo a consciência e entregando os indivíduos à irracionalidade (ADORNO, 1986). Adorno concorda com Freud quanto à formação e as forças subjetivas que estão em operação nos grupos e na massa, mas ressalta que as massas são

[...] um produto social - não uma invariante natural; uma amálgama obtida aproveitando racionalmente fatores psicológicos irracionais, e não uma comunidade originalmente próxima ao indivíduo; proporciona aos indivíduos uma ilusão de proximidade e união. (HORKHEIMER; ADORNO, 1973, p. 87).

A participação em grupos e coletivos que, em tese, deveria minorar os efeitos do “individualismo" exacerbado do capitalismo, na verdade não passariam de mimetismo e de falsa projeção de indivíduos com os egos enfraquecidos, que colocam algo ou alguém no lugar de seu ideal de ego, se identificando uns com os outros narcisicamente. Os grupos acabam sendo instrumentalizados para reforçar a heteronomia e a alienação, pois os instintos inconscientes, bem como a energia tomada de outras instâncias psicológicas, passam a servir a objetivos externos ao indivíduo, fortalecendo a ordem existente (ADORNO, 2006).

Se em nossa sociedade, conforme pontua Adorno, os indivíduos não chegaram a uma integração do ego, a substituição do ideal de ego é bastante facilitada. Sua substituição 
por um "eu do grupo", coletivo e externo ao indivíduo, preenche o vazio deixado pela ausência de integração do ego e pela falta de desenvolvimento autônomo e independente, colocando no lugar a identificação com a autoridade coletiva (ADORNO, 2006).

Assim, a relação entre indivíduo e grupo pode ser alienada, pois está baseada na identificação do líder, dos ideais, valores ou instituições com o ideal de ego do indivíduo, e com a identificação horizontal dos indivíduos entre si, o que acaba gerando uma dominação pelo consenso (ROUANET, 1985).

Adorno, indo além de Freud, vai pontuar que essa identificação, no entanto, não ocorre de fato, mas é "atuada" pelos sujeitos, que no fundo ainda guardam alguma consciência da falsidade da identificação com o líder ou da igualdade entre os participantes do grupo. O investimento libidinal do líder, à semelhança do que ocorre no investimento libidinal da estrela de cinema, promovido pela indústria cultural, não ocorre de forma completamente inconsciente, sendo manipulado pelo ego, envolvendo um ato de vontade do indivíduo, ocorrendo próximo à superfície da consciência. Para o autor, a própria existência do grupo e sua "psicologia" tem um caráter fictício, de simulação:

A categoria de "impostura" (phonyness) se aplica aos líderes tanto quanto ao ato de identificação por parte das massas e a seus supostos frenesi e histeria. Do mesmo modo que, no fundo do coração, as pessoas pouco crêem nos judeus como o demônio, elas também não acreditam completamente no líder. Não se identificam realmente com ele, mas simulam essa identificação, encenam seu próprio entusiasmo e participam, assim, da performance de seu líder. É por meio dessa encenação que atingem um equilíbrio entre seus desejos instintuais continuamente 
mobilizados e a fase histórica de esclarecimento que alcançaram e que não pode ser arbitrariamente revogada. É provavelmente a suspeita do caráter fictício de sua própria "psicologia de grupo" que torna as multidões fascistas tão inabordáveis e impiedosas. Se parassem para raciocinar por um segundo, toda a encenação desmoronaria, e só lhes restaria entrar em pânico. (ADORNO, 2006, p. 188, itálico no original).

Com relação à regressão presente nos indivíduos que participam da massa, Adorno vai pontuar que aqueles que submergem nas massas não são simplesmente homens primitivos, mas indivíduos que em geral apresentam um comportamento dito normal, demonstrando um comportamento contraditório com o que costumam apresentar quando estão sozinhos. A regressão não é simplesmente, então, um retorno do arcaico, mas a atualização deste "na e pela civilização", posto que o esclarecimento a que chegamos não pode ser simplesmente apagado (ADORNO, 2006, p. 170). Cabe lembrar que, se para Freud, a irracionalidade do indivíduo se reflete para o social, para Adorno, o processo ocorre de forma inversa: a irracionalidade do todo social é que suscita a irracionalidade individual e dos grupos.

Quanto mais a ideologia insiste na autonomia do grupo, tanto mais os próprios grupos, como instâncias mediadoras entre a totalidade e o indivíduo, são determinados, de fato, pela estrutura da sociedade. Assim, o grupo, continua exercendo sua função mediadora e seria difícil conceber uma sociedade sem essa função; mas a função mediadora depende hoje, de maneira evidente, do todo societário, como é provável que sempre 
tenha dependido, de uma maneira menos ostensiva. (HORKHEIMER; ADORNO, 1973, p. 74).

O caráter de impostura dos grupos em nossas sociedades faz com que esses necessitem de "dispositivos" específicos para sua formação e manutenção. Alguns desses dispositivos são a repetição e os rituais presentes em vários grupos, que funcionam como um mecanismo de criar artificialmente o vínculo e a identificação horizontal (ADORNO, 2006).

O amor dirigido ao grupo e o ódio dirigido aos outros grupos é uma forma de lidar com a ambivalência presente na relação com os outros participantes, ambivalência essa decorrente dos mecanismos de identificação e de rivalidade pelo amor do líder. Qualquer crítica ao grupo, qualquer divergência com relação ao seu funcionamento ou aos seus valores é sentida pelos participantes como uma perda narcísica, e a prática comum de não ver defeitos no próprio grupo e de ver todos os defeitos e dirigir todas as críticas e a raiva a outros grupos e aos participantes destes, tem um ganho narcisista evidente- elimina a intolerância e a rivalidade dentro do grupo, e funciona como uma "força negativamente integradora":

Freud teve sucesso em identificar a função libidinal desse dispositivo. Ele age como uma força negativamente integradora. Já que a libido positiva está completamente investida na imagem do pai primitivo, o líder, e já que poucos conteúdos positivos estão disponíveis, um negativo deve ser encontrado. [...] É desnecessário dizer que essa integração negativa alimenta o instinto de destrutibilidade [...]. (ADORNO, 2006, p. 180). 
Essa forma de lidar com a ambivalência alimenta um raciocínio dicotômico e uma visão maniqueísta da realidade, onde a afirmação da identidade de um é feita através da negação e do desejo de eliminação do que lhe é diferente, seja outro indivíduo, seja outro grupo (ADORNO, 2006; ZUIN; PUCCI; RAMOS-DE-OLIVEIRA, 1999).

Considerando o caráter artificial e fictício da identificação com o líder, cumpre-nos perguntarmos acerca do perfil do indivíduo que acaba por assumir o papel de substituto do ideal de ego de muitos que o seguem.

Analisando o funcionamento de grupos fascistas, Adorno vai pontuar que o que diferencia o líder do grupo de seus seguidores não é o fato de que o primeiro tenha chegado a um desenvolvimento psíquico mais satisfatório, nem que tenha mais capacidade intelectual que seus seguidores, que o habilitasse para conduzir os outros, mas que possui certas características ou capacidades que o habilita a cumprir uma função na economia psíquica de outros.

A figura do líder recupera a imagem do pai primitivo com sua força e sua autoridade inquestionável. O autoritarismo e o personalismo são então necessários nos grupos artificialmente formados, sendo dispositivos que visam associar a figura do líder ao do pai primevo, contribuindo para provocar uma regressão nos indivíduos, regressão essa que alguns autores assinalam como característica "natural” das massas.

Outra característica do líder é que ele se assemelha psicologicamente aos seus seguidores, mas é capaz de expressar o que neles está latente, dando a impressão de uma maior liberdade libidinal, que é desejada pelos sujeitos. O líder tem a capacidade de "virar o inconsciente" para fora, ou seja, ele usa sua própria irracionalidade e estereotipia para suscitar a identificação com os seguidores. 
O líder pode adivinhar os desejos e necessidades psicológicas dos que são suscetíveis à sua propaganda porque a eles se assemelha psicologicamente e deles se diferencia pela capacidade de expressar sem inibições o que neles está latente, em vez de lançar mão de alguma superioridade intrínseca. Os líderes são geralmente tipos de caráter oral, com compulsão a falar incessantemente e a enganar os outros. O famoso encanto que exercem sobre seus seguidores parece depender largamente de sua oralidade: a própria linguagem, destituída de sua significação racional, funciona de um modo mágico e promove aquelas regressões arcaicas que reduzem os indivíduos a membros de multidões. (ADORNO, 2006, p. 183 e 184).

Na verdade, o líder moderno é uma ampliação coletiva da personalidade do próprio sujeito, e satisfaz o duplo desejo de se submeter e de ser ele mesmo a autoridade, ao dar a impressão de maior liberdade libidinal associada à imagem de uma pessoa comum, alguém do povo (ADORNO, 2006).

Por causa daquelas partes da libido narcisista do seguidor que não foram investidas na imagem do líder, mas permanecem ligadas ao próprio eu do seguidor, o super-homem deve ainda se assemelhar ao seguidor e aparecer como sua ‘ampliação'. (...) A ambivalência psicológica ajuda um milagre social a se realizar. A imagem do líder satisfaz o duplo desejo do seguidor de se submeter à autoridade e de ser ele próprio a autoridade. (ADORNO, 2006, p. 177). 
Nas sociedades modernas, a função exercida pelo líder tem uma importância psicológica tal que sua existência subsiste a despeito dos líderes: a necessidade por uma autoridade externa ao indivíduo, heterônoma, opressiva, independe de quem está exercendo a função e do conteúdo de sua atuação. Assim, o líder ou idéia colocados no lugar do ideal de ego é intercambiável e facilmente substituído, tão logo seja conveniente para o indivíduo, desde que sua função seja mantida (ADORNO, 2006; ADORNO et. al, 1965).

Há que se pontuar, ainda, a importância do que Adorno chama de líderes secundários, em nossas sociedades. Para o autor, na civilização tecnológica em que vivemos, a transferência é cada vez mais indireta e precária; não se dá mais com um indivíduo que encarna o líder, posto que este é cada vez mais distante e desconhecido. A transferência se dá para com os poderes sociais, que sofrem uma "repersonalização regressiva" (ADORNO, 2006, p. 177, nota 2).

A fetichização do grupo, em detrimento da figura do líder, é facilitada em virtude do fato de que a maior parte dos grupos hoje trabalha com a massa não organizada, como a multidão das cidades atuais. Em virtude disso, tais grupos correm o risco de enfatizar demasiadamente a necessidade de organização, criando um fetiche da organização como tal: há um desvio da catexia libidinal da figura do pai amoroso em direção à organização em si, que sofre um superinvestimento.

O caráter fracamente coeso de tais multidões heterogêneas torna imperativo que disciplina e coerência sejam enfatizadas à custa do desejo centrífugo e não canalizado de amar. Parte da tarefa do agitador consiste em fazer a multidão acreditar-se organizada como o Exército ou a Igreja. 
Daí a tendência para a superorganização. Constrói-se um fetiche da organização como tal; ela se torna fim em vez de meio [...]. (ADORNO, 2006, p. 171, nota 9).

A tendência à homogeneidade e ao igualitarismo presentes em certos grupos, na verdade se constituem em um igualitarismo repressivo, afim ao fascismo, posto que deriva de uma identificação horizontal repressiva (ADORNO, 2006).

\footnotetext{
Quanto menos desejam que a estrutura social inerente mude, mais tagarelam sobre justiça social, querendo dizer que nenhum membro da "comunidade do povo" deve se permitir prazeres individuais. Igualitarismo repressivo em vez da realização da verdadeira igualdade pela abolição da repressão é parte e parcela da mentalidade fascista [...]. (ADORNO, 2006, p. 181 e 182).
}

Se as instituições ou líderes são identificados com a autoridade paterna, a simples desobediência à figura de autoridade e às instâncias de dominação poderia ser sentida como um risco, e o sinal de angústia correspondente faria com que toda possibilidade de discordância contra o estabelecido fosse eliminado da consciência (ROUANET, 1985). Assim, a participação em grupos, em uma sociedade administrada e que obriga o indivíduo à regressão e infantilização, também está baseada num infantilismo e numa regressão.

Há que se observar ainda que os indivíduos buscam se submeter, posto que a submissão, seja a um líder, um grupo ou idéia, cumpre funções psicológicas, quais sejam, 
manejar os impulsos alienados do ego, como a dependência, ou servir como sucedâneo do superego do indivíduo, de forma externalizada.

Se Adorno está estudando formações grupais conservadoras e reacionárias, ele deixa claro que também os grupos mais progressistas correm o risco de utilizarem os mesmos mecanismos utilizados pelos grupos e movimentos de massa fascistas, caso percam a fé nas massas ou abram mão do seu conteúdo racional em função da manutenção do poder.

\footnotetext{
Além disso, pode-se perguntar: por que a psicologia de grupo aplicada, aqui discutida, é mais peculiar ao fascismo do que a maioria dos outros movimentos que buscam apoio de massa? Mesmo a comparação mais casual da propaganda fascista com a dos partidos liberais e progressistas mostras que é assim. [...] Entretanto, não há dúvida de que mesmo o movimento político mais progressista pode se deteriorar até chegar ao nível da "psicologia da multidão" e de sua manipulação, se seu próprio conteúdo racional é despedaçado pela reversão ao poder cego. (ADORNO, 2006, p. 186 e 187).
}

Segundo Rouanet (1985), as condições para que exista efetivamente uma comunicação política (a ausência de violência, a liberdade do processo argumentativo, a ausência de coação externa, liberdade plena de propor e contestar normas e a consciência verídica não deformada pelos mecanismos de defesa) nem sempre estão presentes nos grupos progressistas, em função de sua orientação ideológica. Alguns movimentos de esquerda, por exemplo, influenciados pelo stalinismo, não teriam capacidade de fornecer essas condições, pois acreditam e lidam com os indivíduos como se eles não fossem 
capazes de se auto-governar, tornando necessários os intelectuais e/ou a elite governante, acarretando um declínio da vida pública e política.

$\mathrm{Na}$ verdade, o coletivismo nem sempre é sinal de solidariedade, experiência verdadeira ou emancipação, se constituindo nessa sociedade totalitária mais como uma forma de regressão, de infantilização, de alienação e de manipulação, isto é, como uma forma de liquidação do indivíduo (ADORNO, 1986c, 1992).

Os coletivos ditos socialistas, nem sempre são uma garantia de emancipação do indivíduo, ou seja, a consciência reificada "não termina lá onde o conceito de reificação ocupa um lugar de honra." (ADORNO, 1986, p. 64). A ordenação coletivista, que faz desaparecer toda a autonomia do sujeito, nada mais é do que uma resposta reificada à reificação social como um todo, onde quer que ela se encontre (VAZ, 2004).

A solidariedade que se apresenta em algumas formas de socialismo também não passa de reificação; de uma forma disfarçada de obrigação à submissão. Para Adorno, muitos grupos de esquerda desperdiçam as forças de seus participantes, que seriam empregadas para lidar com os adversários da causa, e são usadas para lidar com os dirigentes, dos quais se tem muito medo (ADORNO, 1992).

A conscientização política dos indivíduos poderia se transformar em uma nova forma de opressão e manutenção da falsa consciência, porque "desemboca na contradição da liberdade imposta, e no terrorismo de uma prática conscientizadora baseada no pressuposto da minoria psíquica dos governados" (ROUANET, 1985, p. 316).

$\mathrm{Na}$ atual sociedade, os grupos onde o homem consegue se reproduzir e reproduzir suas condições de vida não são mais os grupos "íntimos", mas grupos artificiais, dentro dos quais os homens não se identificam plenamente. A estrutura social capitalista tende a 
destruir as formações grupais tradicionais, que tinham por características serem autônomas e permitirem a reprodução da totalidade da vida dos indivíduos.

No entanto, cabe lembrar que, para Adorno, são os grupos que dão sentido à humanidade em geral. Para o autor, há uma contra-tendência a esta destruição dos grupos: enquanto os grupos tradicionais tentam sobreviver e novos grupos "sintéticos" e planejados são formados, como os grupos de empresa; grupos espontâneos surgem devido ao tipo de vida capitalista, como os grupos do trabalho, e há o surgimento de novos grupos organizados a partir da base, que em geral protestam contra as injustiças da sociedade, e fornecem ao indivíduo uma possibilidade de vivência coletiva, identificação e solidariedade (HORKHEIMER; ADORNO, 1973).

Adorno demonstra uma opinião mais positiva não só em relação aos grupos, mas também com relação à própria massa, posto que, como Freud, demonstra uma fé nos indivíduos. Para Adorno, as massas não são naturalmente irracionais, mas tem a irracionalidade habilmente promovida e instrumentalizada, por motivos eminentemente econômicos e não psicológicos (ADORNO, 2006).

Adorno, na verdade, vai reconhecer uma contradição dentro da sociedade, que se reflete nos grupos nela inseridos, e exerce influência decisiva tanto na moldagem da subjetividade dos participantes quanto na estrutura desses grupos (ADORNO, 1986b). Para ele, essa contradição só pode ser superada através de sua explicitação, o que possibilitaria uma nova configuração das relações entre os indivíduos e desses com o grupo no qual estão inseridos (ADORNO; HORKHEIMER, 1985).

Como já pontuamos, para o autor, participar de grupos/coletivos é uma "condição óbvia do sentido de humanidade" (HORKHEIMER; ADORNO, 1973, p. 71). À 
semelhança de Freud, Adorno entende que o indivíduo está ligado a vários grupos, e vai formando sua identidade a partir da identificação com uma multiplicidade de coletivos.

Adorno também vai identificar nos grupos uma possibilidade de contraposição à reificação dessa sociedade, ou pelo menos o surgimento de rastros de uma tendência contra a reificação, que pode ser identificada, em especial, nos mais diversos grupos de juventude (ADORNO, 1986c, p. 73). Nesses grupos é que poderiam se encontrar a resistência contra a acomodação imposta pela sociedade vigente, a busca de liberdade para se ter objetivos próprios, a recusa do mundo como aparência e mentira, bem como a atenção para as possibilidades de mudança (ADORNO, 1986c).

Com a participação em grupos que possibilitam uma identificação positiva, um espaço de reflexão e autonomia, os indivíduos têm uma oportunidade de desenvolver sua consciência, sua capacidade de refletir e de chegar a conviç̧ões por meios racionais (ADORNO, 2006).

O potencial reificante ou emancipador da participação em um grupo depende de como se dá essa participação: a adesão cega à coletividade, qualquer que seja ela, leva à regressão, com o indivíduo abrindo mão de sua consciência e de sua auto-determinação; já a participação consciente, refletida, contribui com o desenvolvimento do indivíduo e sua autonomia. 


\section{O MST e a participação}

Quanto mais inconformada com o atual estado de coisas, mais humana é a pessoa.

MST

\subsection{A questão agrária no Brasil e o MST}

O tema da reforma agrária é recorrente no cenário político brasileiro, colocado e recolocado constantemente pela ação dos próprios trabalhadores rurais, que se vêm privados do acesso à terra, ou são expulsos desta (MEDEIROS, 1997).

As lutas populares em torno da questão da terra no país vêm desde a época do Brasil colônia. O campo brasileiro foi constituído, desde seus primórdios, sob a lógica do capitalismo, com uma função bem definida dentro de uma economia capitalista mercantilista, que tinha por base a produção escravista de mercadorias (MARTINS, 1995).

A opção feita por Portugal de colonizar o país tendo como base o comércio de escravos, com a consequente cessão de grandes áreas de terras para poucos donatários que poderiam consumir mão-de-obra escrava, deixou a maior parte da população do campo à margem das grandes unidades, em terras impróprias para cultivo ou já degradadas (MARTINS, 1995; MEDEIROS, 2003). Desde o início da colonização, as contradições do capitalismo e seus desdobramentos, como o desenraizamento, a expropriação do trabalhador, a utilização das terras com funções rentistas, sempre se fizeram presentes no campo brasileiro (MARTINS, 1995). 
Esse alicerce sobre a qual se constituiu o sistema agrário vigente até hoje, acarretou a formação de movimentos sociais contestatórios, a exemplo dos movimentos messiânicos e do banditismo social (GOHN, 2000, 1997; MARTINS, 1995). No século XIX e na primeira metade do século XX, vários movimentos messiânicos já buscavam construir um outro mundo, sem injustiças e com igualdade social (GOHN, 2000; MARTINS, 1995).

Durante as décadas de 1940 e 1950, os movimentos sociais estavam em plena atividade na área rural, e conflitos sociais, que envolviam trabalhadores rurais assalariados, pequenos posseiros, arrendatários, entre outros, ocorriam de forma regionalizada em todas as partes do país, sem maiores articulações nacionais (MEDEIROS, 2003; ROS, 2005). As ações de organização contavam com o apoio do Partido Comunista do Brasil e de setores progressistas da Igreja Católica e da Igreja Luterana (MEDEIROS, 2003; GOHN, 2000). A partir dos anos 60, se destaca o surgimento da Confederação dos Trabalhadores na Agricultura (CONTAG), fruto da aliança estratégica entre a Igreja Católica e o PCB; e a organização das Ligas Camponesas no nordeste do país, que tiveram origem em Pernambuco, mas que se organizaram de forma mais sólida, se espalhando por vários estados do país, e tendo um destaque nacional (MARTINS, 1995; MEDEIROS, 2003; ROS, 2005).

Com o golpe militar de 64, houve um refluxo nos movimentos sociais do campo, que foram duramente perseguidos. Com o projeto de desenvolvimento proposto e implementado pelos militares para a área rural, denominado pelos teóricos de modernização conservadora, houve um acirramento das tensões e dos conflitos no campo, que levaram não só a uma nova organização dos movimentos sociais no campo, a partir do final da década de 70, como ao seu fortalecimento (GOHN, 2000, 1997; MARTINS, 1995; MEDEIROS, 2003; ROS, 2005). 
Dentre os movimentos sociais atuais, o MST é considerado o mais importante contestador das relações sociais e de poder, não só no Brasil como em toda a América Latina (GOHN, 2000; PETRAS, 1997). Tal importância se justifica em função da situação de conflito em torno da terra estar longe de ser equacionado. Hoje, no Brasil, a desigualdade na distribuição de terras se mantém, o que faz com que grandes contingentes da população não tenham condições de sobrevivência garantida.

O grau de concentração de terra e renda, medido através do índice de Gini, marcava 0,802 no ano de $2000^{1}$. Em 1967 , esse índice era de 0,836 , o que mostra quão pouco evoluímos em termos de desconcentração fundiária e democratização do acesso à terra e, consequentemente, das relações sociais no campo (MDA, 2006).

A existência de grandes populações à margem da propriedade da terra, leva a conflitos e a várias formas de violência, como agressões físicas, torturas, chegando até a assassinatos em massa. Números do Ministério do Desenvolvimento Agrário (MDA), referentes ao ano de 2005, falam na impressionante cifra de 1881 conflitos no campo, com 102 mortos, 266 ameaças de morte, 33 torturados e 166 feridos (MDA, 2006). A Comissão Pastoral da Terra (CPT) e os vários movimentos sociais do campo referem um número muito maior de vítimas. Muitos outros exemplos podem ser dados que indicam "o poder do atraso" (MARTINS, 1994) presente no campo brasileiro, como a persistência do trabalho escravo, o coronelismo, a constante expulsão de posseiros e populações tradicionais de suas terras.

Tendo esse contexto como pano de fundo para seu surgimento, o MST desponta como movimento social capaz de organizar e mobilizar um grande número de trabalhadores

\footnotetext{
${ }^{1} \mathrm{O}$ índice de Gini varia de 0 a 1; quanto mais próximo de 0 , menor a desigualdade na distribuição de terra; quanto mais próximo de 1 , mais desigual a distribuição.
} 
rurais sem terra, oriundos das mais diversas situações sociais, culturais e econômicas, com experiências de vida diferentes, que estavam expropriados de seu meio de vida. Assim, aglutinam-se no MST filhos de pequenos proprietários, posseiros, arrendatários, atingidos por barragens, trabalhadores urbanos desempregados, entre outros.

Seu surgimento ocorreu no final da década de 70, a partir de lutas de movimentos regionais isolados, em várias partes do Brasil, em especial no centro-sul do país (CALDART, 2004; FERNANDES, 1997). Ele nasceu como um movimento de enfrentamento e resistência à política agrária do governo militar, e se considera como herdeiro das Ligas Camponesas (FERNANDES, 1997; STÉDILE, 1997).

A principal estratégia de luta e de pressão do MST é a ocupação de terra, que segundo Caldart (2004) é a essência desse movimento, e que para outros autores, o diferencia de outros movimentos sociais do campo (MEDEIROS, 2003). Segundo Ros (2005), nos primórdios do MST, este só era considerado criado em um estado se ali ocorresse uma ocupação patrocinada por integrantes do Movimento. Outras ferramentas de luta são as marchas, as ocupações de prédios públicos, as manifestações públicas, os eventos realizados em universidades, a utilização dos espaços na mídia, as campanhas de doação de sangue, entre outras (COLETTI, 2003; ROS, 2005).

A primeira ocupação promovida pelo que depois veio a ser conhecido como o MST se deu na Fazenda Macali, no município de Ronda Alta, RS, em sete de setembro de 1979. Essa ocupação foi realizada por posseiros que haviam sido expulsos das terras indígenas Kaigang, e não tinham aceito uma proposta do governo de serem enviados para o Mato Grosso. Cerca de 500 famílias estavam acampadas nas beiras de estradas, esperando providências do governo. Através de um trabalho de mobilização que envolveu a igreja e alguns militantes, os acampados decidiram ocupar a fazenda Macali, de 1.600 hectares, 
terra estatal que estava grilada por um fazendeiro. Com a ocupação, o governo retomou as terras e foi obrigado a criar um assentamento no local (STÉDILE; FERNANDES, 1999). Essa primeira ocupação vitoriosa serviu de incentivo para a adoção desse método, e para a realização de novas ocupações.

Nesse mesmo período, começaram a ocorrer ocupações ou resistências de posseiros em serem expulsos da terra, em vários estados do Brasil, que contribuiriam para a criação do MST nesses estados - Santa Catarina, Paraná, São Paulo e Mato Grosso do Sul (FERNANDES, 1997). Outros conflitos ocorriam também nos estados do Rio de Janeiro, Bahia e Minas Gerais (FERNANDES, 1997). Uma outra ocupação considerada importante para o surgimento do MST ocorreu na Encruzilhada Natalino, também no Rio Grande do Sul, no ano de 1981, no qual participaram mais de 30.000 pessoas, oriundas de vários estados do país, com o intuito de apoiar o Movimento dos Sem Terra e a luta pela democratização da sociedade brasileira (CALDART, 2004).

Após um longo processo de contatos e articulação entre as lideranças desses movimentos regionais, se organizou em janeiro de 1984, em Cascavel - Paraná, o I Encontro Nacional dos Trabalhadores Sem-Terra, considerado o marco de fundação do MST, com 80 representantes de 16 estados brasileiros (FERNANDES, 1997; MST, 2004; STÉDILE, 1997).

Segundo Ros (2005), há uma certa concordância entre os teóricos quanto aos principais determinantes históricos que levaram ao surgimento do MST. Destacam como aspectos de maior relevância: o papel das mudanças ocorridas na agricultura e seus impactos sobre as populações rurais; o início do processo de liberalização política e do ocaso do regime militar nos final dos anos 70; e o apoio das Igrejas às lutas das populações rurais no período militar. 
Assim, para o surgimento do MST, houve a contribuição de três principais segmentos sociais:

1) o segmento institucional religioso, com participação da Igreja Católica, por meio das Comunidades Eclesiais de Base e da Comissão Pastoral da Terra; e da Igreja Evangélica de Confissão Luterana, no caso do MST dos estados da região sul do país (FERNANDES, 1997; STÉDILE, 1997);

2) o segmento sindical e político-partidário, seja através dos movimentos sindicais de oposição, como os Sindicatos de Trabalhadores Rurais filiados à FETAESP (Federação dos Trabalhadores do Estado de São Paulo) ou à CUT (Central Única dos Trabalhadores) (FERNANDES, 1997; STÉDILE, 1997); seja através dos partidos políticos, como o PT e o PMDB (FERNANDES, 1997);

3) os militantes de diferentes organismos, que segundo Stédile (1997, p. 102), “viam na luta pela reforma agrária uma luta também contra a ditadura militar e pela redemocratização do país".

Muitos autores têm assinalado a importância do MST no processo de transformação social e de democratização da sociedade brasileira. Para D’Incao (1997), o MST interroga preconceitos tanto de grupos de direita, quanto de grupos de esquerda, colocando novos desafios para o debate político, fomentando o ainda frágil processo de negociação democrática sobre os rumos da sociedade brasileira. Para Brenneisein (2002), as relações de patrimonialismo e autoritarismo, que marcam toda a sociedade brasileira, são ainda mais 
fortes no campo, e é justamente ao questionar essas relações que o MST contribui para o avanço da democracia.

Contando a partir da data considerada como a da sua fundação oficial, o MST soma hoje 25 anos de existência, e está presente em 24 estados da federação (MST, 2009). Sua estrutura organizacional, bastante complexa, conta com instâncias diretivas nacionais, estaduais, regionais e em cada assentamento e acampamento onde está presente (FERNANDES, 1996; MST, 2004; STÉDILE, 1997). Na organização do movimento como um todo, e em cada uma de suas instâncias, devem ser contemplados os seguintes “princípios organizativos” (CALDART, 2004; STÉDILE, 1997, p. 104), com o fim de possibilitar o crescimento do MST e ao mesmo tempo manter a unidade política de um movimento social que é nacional:

1) a vinculação da liderança com as bases, com um trabalho permanente junto às bases e à massa;

2) a organização das massas para a luta social, pois a mudança social somente vai ocorrer se o povo lutar por ela;

3) a divisão de tarefas entre os membros, em forma de comissões;

4) a direção coletiva em todas as instâncias, desde as comissões de base até a direção nacional;

5) a disciplina, com regras coletivamente definidas e respeitadas;

6) a formação de quadros, com estudo e capacitação, a fim de fortalecer a luta para alcançar os objetivos da organização; 
7) a mística, como uma liturgia capaz de motivar e conscientizar a base, bem como despertar a esperança de que pode haver uma sociedade diferente, mais solidária, justa e fraterna.

Assim, o MST é um movimento bastante organizado, não só em sua estrutura funcional, como também com as ações que desenvolve, como as ocupações, os acampamentos, os protestos, etc, que são planejados e preparados com bastante antecedência (GOHN, 2000). Alguns teóricos, tanto aqueles ligados ao Movimento quanto os seus críticos, vão pontuar que o MST hoje pode ser considerado como uma organização, mais do que um movimento social (CALDART, 2004; MARTINS, 1997; NAVARRO, 2002; STÉDILE; FERNANDES, 1999).

Para Stédile (1997), os princípios organizativos são o que diferencia os MST dos outros movimentos sociais anteriores, do qual ele é herdeiro. Esses princípios que norteiam toda a organização do Movimento, e que são aplicados por todas as instâncias diretivas, foram construídos ouvindo-se as experiências dos participantes de movimentos sociais prévios ao MST, procurando-se compreender onde eles erraram, onde acertaram, por que o movimento não subsistiu. Assim, os princípios organizativos foram construídos com o objetivo de manter a perenidade do MST, e o transformam em mais do que um movimento social, em uma “organização política e social de massas ou dentro do movimento de massas" (STÉDILE; FERNANDES, 1999, p. 81).

Martins (1997, p. 63) chega a considerar o MST como partido político, “o primeiro e único partido popular agrário que temos no Brasil”. Tal leitura é rechaçada pelos teóricos ligados ao MST, que vão considerar o MST como um movimento de massas que é ao mesmo tempo também uma organização social, mantendo as características dos dois tipos 
de fenômeno social (CALDART, 2004). O MST se pretende, assim, como um movimento de massas, com o fim precípuo de conduzir a "luta de massas" (ROS, 2005, p. 140).

Além das instâncias diretivas, o MST conta com setores de atuação específicos em sua organização, como os Setores de Educação, de Formação, de Produção, de Finanças, de Comunicação, de Frente de Massa (BRENNEISEIN, 2002). O MST criou ainda várias figuras jurídicas, como a Cooperativa Central dos Assentados (CCA), a Confederação das Cooperativas de Reforma Agrária (CONCRAB), entre outras. Segundo o MST, eram, em 2004, mais de 500 associações de produção, comercialização e serviços, 49 Cooperativas de Produção Agropecuária (CPAs), 32 Cooperativas de Prestação de Serviços (CPSs), duas Cooperativas Regionais e 3 Cooperativas de Crédito (MST, 2004).

Cabe pontuar que não é muito clara a estrutura organizativa e administrativa do Movimento, quiçá por questões de proteção aos ocupantes dessas estruturas e do próprio MST. Stédile e Fernandes (1999) são os que mais discorrem sobre esse assunto, relatando que a Direção Nacional é composta por 21 membros, e que há eleições quando o número de candidatos é maior do que o número de vagas em aberto. Também pontuam que a relação das Direções Regionais e Estaduais com a Nacional não é de hierarquia, mas que as primeiras têm liberdade para aplicar os princípios organizativos e as linhas políticas do Movimento de acordo com a realidade local.

O MST é combatido fortemente pelas forças conservadoras da nossa sociedade, sendo inúmeras as tentativas de intimidação, de desmobilização, e até de extinção do Movimento, sejam por vias institucionais (mídia, judiciário, polícia, etc.) e não institucionais, paralelas ou ilegais, como é o caso de assassinatos, ameaças de morte, intimidação por pistoleiros, etc... Como pontuam alguns líderes do Movimento, essa 
disputa pode ser comparada a uma guerra, com várias baixas do lado dos trabalhadores sem terra.

A mídia é bastante crítica ao MST, veiculando notícias que procuram associar os demandantes por reforma agrária (que como pontuam vários estudiosos do tema, são os pobres do campo e da cidade) com bandidos, baderneiros, guerrilheiros e até terroristas. Os participantes do MST são caracterizados como violentos, selvagens, ladrões e até estupradores (REVISTA VEJA, 28 de janeiro de 2009).

Não menos duros costumam ser algumas instituições do Estado, como a polícia e o Judiciário. Recentemente, a mídia veiculou a história de um promotor do Rio Grande do Sul, que pediu judicialmente a extinção do Movimento dos Sem Terra, pois segundo ele, o MST seria formado por "alguns desvalidos, vários aproveitadores e muitos bandidos" (REVISTA VEJA, 28 de janeiro de 2009, p. 49). Mais recentemente ainda, as escolas de educação itinerantes, que permitiam às crianças e jovens de acampamentos ter acesso à educação, foram fechadas devido a uma ação do Ministério Público do Rio Grande do Sul aliás, ação proposta pelo mesmo promotor que pediu a extinção do Movimento.

A estrutura organizacional do MST foi construída como uma forma de resposta/reação a essa tentativa de desmobilização, como uma tentativa de blindagem a essa repressão violenta (CALDART, 2004). Muitas vezes, inclusive, o Movimento é classificado como agressivo e culpabilizado por reagir à violência à qual é submetido.

Segundo Coletti (2003), o MST cresceu num período de refluxo de outros movimentos sociais, em função do perfil de seus participantes. Sua base social seria formada por indivíduos de três grupos diferentes: aqueles cuja relação com a terra ele classifica de "precária", em função de quantidade de terras não suficiente para sustentar a família ou aqueles que perderam suas terras; trabalhadores urbanos desempregados que não 
encontram mais condições de vida na cidade; e trabalhadores rurais precários, os chamados “bóias-frias". Tendo como referência as teorias de Anderson (1986), o autor conclui que os constrangimentos econômicos e o medo de exclusão, que silenciam e produzem indivíduos obedientes e submissos, atingiriam em menor grau as bases do MST, que não são ameaçados pelo desemprego, posto já serem excluídos.

Vários autores vão falar das transformações pelas quais passou o MST nesses 25 anos de existência, chegando a dividir sua história em fases (BRENNEISEIN, 2002; CALDART, 2004; GOHN, 2000; FERNANDES, 1997; ROS, 2005). Essas transformações, causadas por alterações no cenário político, nos parceiros, ou por novos desafios colocados no dia-a-dia de atuação do MST, abrangem aspectos de sua estrutura e organização, sua metodologia de atuação, e as concepções acerca de seus objetivos e da abrangência de sua luta.

Caldart (2004) narra um momento interessante e pouco pontuado na constituição do MST, quando são criados os primeiros assentamentos, decorrentes do trabalho de organização e pressão social exercida pelo Movimento, com as consequentes adaptações que o MST teve que sofrer para contemplar essa nova realidade social. Nessa ocasião, discutiu-se a possibilidade de criação de um novo movimento social, o "Movimento Pé No Chão", para organizar e lutar pelos interesses específicos dos assentados. Decidiu-se, ao final, que o MST também seria a organização representante das famílias assentadas, em função de dois pontos: chegou-se à conclusão de que a existência de um movimento separado para acampados e assentados poderia enfraquecer os dois segmentos; e que o trabalho do MST no assentamento poderia contribuir para avançar a luta pela reforma agrária, ao constituir os assentamentos como locais de "relações sociais alternativas" (CALDART, 2004, p. 138). O cotidiano da luta no assentamento produziria assim uma 
[...] coletividade cujas ações cotidianas, ligadas a uma luta social concreta, estão produzindo elementos de um tipo de cultura que não corresponde aos padrões sociais e culturais hegemônicos na sociedade capitalista atual, e na brasileira em particular, inscrevendo-se no que poderíamos talvez chamar de um movimento sociocultural que reflete e prepara mudanças sociais mais profundas. (CALDART, 2004, p. 34).

O MST passou assim a representar também os assentados, tornando-se o seu movimento social. Em função dessa opção, as lideranças do MST dedicaram seu tempo a discussões e estudos sobre a melhor forma de trabalhar com os assentados, a fim de mantêlos mobilizados na luta e avançando na consciência (CALDART, 2004).

Outro ponto que sofre alterações ao longo de sua existência, segundo Brenneisein (2002), foram as próprias concepções ideológicas que estruturam as ações e a própria organização, com a adesão da direção ao leninismo e a opção pelo centralismo democrático, com as consequentes alterações em sua metodologia de atuação e sua estrutura. Segundo Ros (2005), o "leninismo" a que Brenneisein se refere é decorrente da comparação do MST ao Partido Bolchevique na Rússia do século passado, cujo funcionamento se caracterizava por enfatizar

[...] a necessidade de reunir um seleto grupo de dirigentes imbuídos por uma grande capacidade de direção e uma rígida disciplina, norteados pelo princípio do centralismo democrático, onde as decisões tomadas pela 
coletividade do partido deveriam ser seguidas à risca. (Ros, 2005, p. 144).

Cabe salientar que a compreensão do MST como sendo leninista, feita por Brenneisein (2002), é criticada por Ros (2005), para quem tal interpretação pressupõe uma "correia de transmissão", na qual as decisões tomadas pelos dirigentes têm que ser inevitavelmente seguidas, o que em tese desconsideraria que os processos sociais se dão no plano de relacional, o que tem como consequência o fato de que a base não se comporta de forma passiva frente às decisões da cúpula do MST, sendo que essas têm que ser negociadas.

Houve transformações também na relação do MST com os seus parceiros, como a Igreja, não só em função das alterações pelas quais passou o movimento, mas também em função de mudanças internas na própria Igreja, que causaram um refluxo de seu apoio aos movimentos sociais progressistas (GOHN, 2000; ROS, 2005).

Um outro aspecto que é sinalizado pelos pesquisadores como tendo sofrido mudanças, é a postura do MST frente aos participantes, com adaptações em sua proposta de trabalho coletivo, visando contemplar o desejo dos agricultores de manter espaços individuais e familiares de trabalho (BRENNEISEIN, 2002; GOHN, 2000).

A postura do poder público frente às demandas do MST também variou muito ao longo desse período. Da surpresa inicial, passou à criminalização do movimento social no período do governo do presidente Fernando Henrique Cardoso, e a uma suposta simbiose no atual governo, do presidente Luiz Inácio Lula da Silva (BRENNEISEIN, 2005; CALDART, 2004; MEDEIROS, 2003). Dois episódios violentos da luta pela terra mostram uma curiosa (e triste) inflexão na forma de tratamento da questão agrária pelos entes 
públicos no país. Em agosto de 1995, na cidade de Corumbiara, em Rondônia, ao realizar um despejo judicialmente autorizado, a polícia agiu com imensa brutalidade e à noite, o que é proibido, tendo matado vários trabalhadores sem terra, no que ficou conhecido como o "Massacre de Corumbiara". No ano seguinte, no mês de abril, em Eldorado do Carajás, no Pará, a polícia matou brutalmente 17 trabalhadores sem terra. As imagens feitas por um cinegrafista não deixaram dúvida quanto à brutalidade e covardia da ação, perpetrada por agentes públicos. Segundo Medeiros (2003), esses acontecimentos apontavam a mudança no padrão de violência no campo: antes, os assassinatos eram cometidos por milícias privadas e pistoleiros, a serviço dos fazendeiros; já na década de 90 , cresceu o número de ocorrências violentas patrocinadas pelo próprio Estado, confirmando o fato da questão agrária ser tratada como caso de polícia. Esses acontecimentos evidenciam que os desafios que motivaram o surgimento do MST continuam colocados para a sociedade brasileira, e a luta pela terra é mais atual do que nunca.

Outro ponto que começa a ser levantado é o impacto de programas sociais na demanda por reforma agrária. Considerando que, como diz Sigaud (2005), quando ingressa no movimento social, o objetivo do indivíduo não é lutar pela reforma agrária ou transformar a sociedade, mas a busca por uma opção de sobrevivência dentre o leque de possibilidades fornecidas pelo seu entorno, avaliações iniciais têm indicado uma pretensa diminuição no número de demandantes por reforma agrária, em função do aumento de programas de transferência de renda, o que em tese teria diminuído a disposição a participar de ações mais incisivas, como as ocupações de terra (FOLHA DE SÃO PAULO, 04/11/2007).

Esse dado é utilizado, por setores mais conservadores da sociedade, como justificativa de que a reforma agrária não é mais uma demanda popular e de que a questão 
agrária e fundiária não é mais um problema no Brasil. Ademais, postulam que a "incipiente" demanda por terra pode então ser resolvida com a chamada "reforma agrária de mercado", que no Brasil é representada pelo Programa Nacional de Crédito Fundiário, anteriormente conhecido como "Banco da Terra", programa do governo federal, apoiado por entidades como o Banco Mundial, que postulam a realização do acesso à terra através de compra de terras no mercado, por meio de empréstimo do governo, que deve ser pago em 10 anos, com um período de carência de 3 anos (MEDEIROS, 2003; NAVARRO, 2002).

As críticas feitas pelos vários movimentos sociais e demais atores ligados à reforma agrária a esse modelo (reforma agrária de mercado) incluem desde sua inviabilidade econômica, até a baixa qualidade das terras negociadas, incluindo a ausência da assistência estatal como responsável pelo processo (MEDEIROS, 2003; RSJDH, 2004). Além disso, a importância da reforma agrária não se resume à redistribuição de terra e ao acesso a esta pelos trabalhadores rurais. A reforma agrária assume uma função estratégica no avanço da democracia e na modificação das relações de poder na sociedade brasileira, sendo uma questão que envolve não só aqueles que são ligados à área rural, mas o conjunto da sociedade (BRENNEISEIN, 2002; ROS, 2005).

Para Caldart (2004, p. 59), especialmente a partir de 1997, o MST passa a considerar como tarefa central a formação de pessoas, o que pode ser exemplificado na sua participação na discussão de um projeto popular de desenvolvimento para o país que rompa

[...] com a mentalidade de povo colonizado, para que se possam tomar decisões ou fazer as escolhas necessárias à construção de uma nova concepção de desenvolvimento que traga de volta, ao mesmo tempo, a 
idéia de Nação e os ideais de justiça social, de solidariedade, de igualdade e de participação do povo como sujeito de seu próprio destino. (Caldart, 2004, p. 59).

Seus objetivos, segundo o próprio Movimento (MST, 2004), são:

1) "construir uma sociedade sem exploradores e onde o trabalho tem supremacia sobre o capital;

2) a terra é um bem de todos. E deve estar a serviço de toda a sociedade;

3) garantir trabalho a todos, com justa distribuição de terra, de renda e das riquezas;

4) buscar permanentemente a justiça social e igualdade de direitos econômicos, políticos, sociais e culturais;

5) difundir os valores humanistas e socialistas nas relações sociais;

6) combater todas as formas de discriminação social e buscar a participação igualitária da mulher.”

Segundo a Carta do $5^{\circ}$ Congresso Nacional, realizado em Brasília em junho de 2007, o MST se compromete a ser um dos que ajuda na organização do povo para que este lute por seus direitos e contra a desigualdade e as injustiças sociais. A seguir, lista vários objetivos, começando pela construção de um projeto popular para o país, passando pela reforma agrária e pelas lutas do campo (contra o latifúndio, a violência no campo, pela limitação do tamanho máximo de propriedade, contra o trabalho escravo, pelos movimentos 
sociais do campo), pela educação em todos os níveis para a classe trabalhadora, contra as privatizações, e chegando à integração dos povos latino-americanos e dos "povos que sofrem agressões do império" (MST, 2007, p.2).

Além dos objetivos acima citados, o MST explicita a importância da luta pela igualdade nas relações entre os homens em vários outros momentos. Assim, Stédile (1997) diz que, com relação à organização interna, "todas as instâncias do movimento, desde as comissões de base, dentro de um acampamento, até as instâncias nacionais, são exercidas coletivamente, na forma de colegiado, sem distinção de poder" (p. 104), ou que a existência de regras devem ser "coletivamente discutidas" (p. 105). Para Caldart e Kolling

[...] o MST é um espaço social de transformação das pessoas: através da luta coletiva, excluídos viram cidadãos; e se o olhar, que antes não se desprendia do chão, aos poucos se eleva e é capaz de encontrar outro olhar refletindo nele o brio de quem passou a acreditar que pode ser sujeito da história, ou a indignação de quem não admite mais ser 'tirado da roda' [...]. (CALDART; KOLING, 1997, p. 237)

Entre os desafios e os compromissos que o MST coloca para sua atuação, está o de "praticar a solidariedade e revoltar-se contra qualquer injustiça, agressão e exploração praticada contra a pessoa, a comunidade e a natureza" (MST, 2004).

Uma das preocupações demonstrada pelo MST é com a educação, que evidencia uma valorização por parte do Movimento com relação à formação dos indivíduos. O olhar presente no MST se dirige tanto à educação formal quanto à não formal, bem como com a formação técnica e política dos seus militantes (GOHN, 2000; MST, 2004). 
Para o MST, tal ênfase na educação se justifica pelo fato de os participantes se constituírem "como um novo sujeito social, no sentido de sujeito coletivo que passa a participar dos embates sociais" (CALDART, 2004, p. 34). Ao participarem da luta pela terra, os sujeitos reorganizariam sua identidade social a partir dessa experiência singular, posto que a ocupação de terra e a vida no acampamento proporcionam uma experiência que questiona os padrões culturais prévios dos acampados, levando a uma "mudança de conceitos, de valores, de postura diante de determinadas realidades" (CALDART, 2004, p. $35)$.

Os Sem Terra, como sujeitos sociais e culturais, seriam diferenciados dos participantes de outros movimentos sociais por aquilo que a autora vai denominar de "enraizamento projetivo": a experiência de participar no MST proporciona o enraizamento de uma população que antes era desenraizada, ao mesmo tempo em que fornece um projeto de futuro, de "algo que ainda não é, mas pode vir a ser" (CALDART, 2004, p. 35).

Assim, passa a ter importância uma educação que leve em conta a realidade dos sujeitos envolvidos, que questione o já dado e contribua com uma construção e uma escolha consciente dos valores que movem os indivíduos (CALDART, 2004).

O MST tem recebido reconhecimento por parte de importantes instituições e organismos internacionais, bem como da população em geral, como um importante movimento na luta pela igualdade e pela valorização dos direitos humanos. Como exemplos, podemos citar o Prêmio Nobel Alternativo, do parlamento sueco, recebido em 1991; o Prêmio Nacional de Direitos Humanos Vladimir Herzog; a medalha Chico Mendes pela luta contra a violência no campo; a Menção de Honra do Prêmio Rei Balduíno, da Bélgica, recebido em 1994, e o Prêmio UNICEF de educação infantil, recebido em 1995. Quanto ao reconhecimento dado pela opinião pública nacional, citamos a pesquisa realizada 
pelo IBOPE em março de 1997, relatada por Frei Beto (1997), de que a maior parte da população apóia a luta do MST e a considera justa (94\% dos entrevistados), apoiando inclusive as ocupações de terra (85\%), desde que sem violência e mortes; e o confisco e distribuição de terras improdutivas (88\%). Assim, podemos observar que o MST, além de valorizar entre seus objetivos a igualdade entre os indivíduos, é reconhecido no mundo todo por promover essa igualdade.

Dessa forma, teóricos ligados ao Movimento o têm incluído como parte de um processo que projeta um mundo ou um tipo de sociedade que ainda não existe, mas cuja idéia está viva no imaginário daqueles que não aderiram ao "pensamento único" (CALDART, 2004, p. 42).

Num mundo dominado pela indústria cultural, onde o capitalismo impera, e a barbárie ameaça a todos, a sociedade olharia o MST

[...] tentando enxergar o que falta a ela mesma, em um tempo caracterizado pela desumanização, pela degradação moral, e por uma sensação de caos social. A miséria social tem se desdobrado em uma miserabilidade espiritual ou ética, igualmente desumanizadora e carente de forças sociais que a contraponham, sendo capazes de reacender esperanças nas pessoas. (CALDART, 2004, p. 48). 


\subsection{O MST e os assentamentos}

$\mathrm{O}$ assentamento de trabalhadores rurais tem sido a principal resposta do Estado à pressão exercida pelos movimentos sociais demandantes por reforma agrária, no caso do Brasil, se constituindo assim como uma tentativa de intervenção e controle estatal sobre um conflito social (CAUME, 2002; GOHN, 2000; MEDEIROS, 2003). Por outro lado, ainda que os assentamentos sejam uma política estatal, o movimento social tem um papel essencial na definição das características, da forma de estruturação e organização espacial e social do assentamento (BRENNEISEIN, 2002). Os assentamentos se constituem assim, desde a sua criação, como um espaço em disputa (CAUME, 2002).

Os próprios dados sobre o número de assentamentos e de famílias assentadas no Brasil são conflitantes, posto que calculados a partir de bases diferentes, bem como com intenções diferentes. Assim, dados apresentados por órgãos estatais vão indicar a criação de 6.598 assentamentos entre os anos de 1995 a 2006, com um total de 922.123 famílias assentadas nesses projetos (MDA, 2006b). Já os movimentos sociais, sindicatos e igrejas indicam, no entanto, um número muito inferior a este (COLETTI, 2003). Para eles, o governo incluiria entre os números de famílias assentadas os casos de substituição em lotes, reassentamentos populacionais, entre outros. Os números de assentamentos seriam muito inferiores então.

Com relação ao número de assentamentos ligados ao MST, dados fornecidos pelo próprio Movimento, indicam que há 1.649 assentamentos no país, que foram frutos de ocupações ou do trabalho de mobilização realizado pelo Movimento, assentamentos esses nos quais residem 105.466 famílias com alguma relação com o MST (MST, 2009). 
O assentamento é considerado tanto por estudiosos da área quanto pelo próprio movimento social como um momento da luta diferenciado do acampamento, posto que o assentamento dos trabalhadores é sinal de que a terra já foi 'conquistada', e começa-se a organizar uma nova comunidade (CALDART, 2004; CONCRAB, 2004; ROS, 2005; TURATTI, 2005).

Se há certa concordância quanto ao fato de que o assentamento é um momento diferenciado do acampamento na luta pela terra, a leitura que se tem dos assentamentos e de seu "sucesso" é altamente influenciada pelo olhar e pela posição ideológica assumida (ou não) por aquele que fala. No caso de analistas dos assentamentos que são contrários à reforma agrária, para além do discurso utilizado pela mídia de que os assentamentos são compostos por "bandidos" e "baderneiros", que não respeitaram o direito de propriedade e não obtiveram a terra por esforço de seu trabalho, juntam-se o discurso de alguns acadêmicos que classificam os assentamentos como "favelas rurais", ou seja, como um local de moradia dos miseráveis do campo, que não têm nenhuma vocação para agricultura, que somente vivem ali e não produzem a contento (GRAZIANO, 2006).

O que se pode pontuar, é que a grande maioria dos estudos constata que a existência de assentamentos tem um impacto positivo nas regiões onde são criados, que em geral são cidades pequenas com uma certa estagnação econômica. Vários são os estudos que indicam que com a chegada de assentamentos, há uma dinamização da economia local, com o aumento do mercado consumidor, proporcionado pela inserção de novas famílias - os assentados - na rede de consumo regional, gerando vários empregos urbanos nas áreas de comércio e serviços; bem como com um aumento da oferta de produtos alimentícios de boa qualidade e em variedade, que passam a ser colocados por essas famílias no mercado próximo ao assentamento (ROS, 2005). Uma fazenda que contava com apenas um 
proprietário, que em geral sequer morava na localidade, bem como consumia os produtos em geral adquiridos em uma grande cidade; que produzia em regime de monocultura e para consumo de grandes centros consumidores, é substituído por uma centena de famílias que consomem produtos locais e produzem para o mercado regional (MEDEIROS, 1997; ROS, 2005; SAUER, 2005). Também ocorrem mudanças sociais e nas relações de poder, como decorrência da criação de um assentamento e a incorporação de novos munícipes na dinâmica de poder político local, munícipes esses que questionam e exigem o atendimento de suas demandas, o que tem como decorrência uma alteração nas correlações de forças locais e regionais (ROS, 2005; SAUER, 2005).

Além disso, vários estudos têm demonstrado uma melhora da qualidade de vida dos indivíduos que são assentados, comparando-se sua situação econômica antes e depois de serem assentados, bem como a posse de bens materiais e de consumo, e o acesso a bens e serviços como saúde e educação, sendo que neste último item há um aumento substancial da escolaridade da população assentada, em relação ao período anterior ao assentamento (LEITE et al, 2004).

Vários teóricos também têm pontuado que a participação no movimento social de luta pela terra, para além do assentamento, contribui com a construção de uma identidade coletiva e com a reconstrução da subjetividade individual (CAUME, 2002; SCHREINER, 2002).

Também é bem estabelecido, entre teóricos favoráveis à reforma agrária, o impacto positivo da participação em um movimento social de luta pela terra, em termos de reorganização da identidade, questionamento dos valores estabelecidos, aprendizagem de uma forma de organização e luta coletiva, aprendizagem quanto a auto-organização, 
negociação, participação política, bem como a aprendizagem de uma postura crítica frente ao mundo (SCHREINER, 2002).

Para alguns teóricos de orientação mais progressista, bem como para os teóricos ligados ao Movimento, o assentamento é considerado como uma "área liberada" ou como um "território liberado", ou seja, uma área conquistada ao sistema capitalista, onde irá se constituir uma comunidade sujeita a princípios socialistas, com novas relações sociais humanas e solidárias, diferenciada do entorno capitalista.

Segundo essa visão, é dentro desse espaço que o novo sujeito coletivo, constituído na luta pela terra, vai se desenvolver na direção de uma consciência plena, sendo que o assentamento seria um vislumbre do novo mundo que se pretende construir (ANCA, 2002; CONCRAB, 2004). O assentamento seria assim um local de novas relações sociais, relações estas construídas sobre valores de igualdade, justiça social, sem discriminação e livre do autoritarismo e da opressão (ANCA, 2002; CONCRAB, 2004).

Dessa forma, o assentamento assume uma importância estratégica no avanço da luta e dentro do trabalho do MST de construção de uma nova sociedade e de um "novo ser", e tem a função de mostrar para a sociedade como a alternativa proposta é viável e desejável.

Cabe pontuar que na origem do MST, essa visão de uma nova sociedade e de um mundo novo, foi muito influenciada pela ligação com as igrejas, que procuravam com o assentamento criar uma possibilidade de vida comunitária, que seria um exercício de vida plena, uma espécie de vislumbre do que seria a vida no Reino de Deus (POLETTO, 1997).

Se por um lado, vários autores têm demonstrado o avanço nas relações sociais e na democratização da sociedade brasileira trazido pelo MST, por outro lado, alguns autores têm sinalizado a presença de conflitos e dificuldades de relacionamento na nova comunidade, bem como a reprodução de relações assimétricas em algumas situações dentro 
do MST, em especial dentro dos assentamentos de reforma agrária implantados em função de sua ação. A união e a participação igualitária percebida durante o acampamento seriam substituídas por uma fragmentação e uma desmobilização dos assentados.

Segundo Leite (1997), há uma certa romantização do assentamento, alimentada pela imagem que o próprio grupo procura passar de si mesmo, de um comunitarismo interno, que nega as tensões inerentes a todos os processos sociais. Se as tensões e os conflitos são fato, as explicações para o fenômeno são diferentes, ora reportando-os à ação do movimento social, ora à ação dos assentados, ora à ação de outros atores que passam a atuar no espaço do assentamento.

Navarro (2002), analisando o MST a partir da tese de Michels (1911) da "lei de ferro da oligarquização das organizações" conclui que o MST é uma organização política cujo fim é a sua própria subsistência, e que, portanto, perdeu seu caráter de novidade e repete a mesma trajetória de outros grupos políticos de esquerda, disputando a hegemonia da representação dos pobres do campo, competindo com outras organizações políticas, e reiterando o controle social sobre a base, contribuindo assim mais com a submissão do que com a emancipação dos pobres do campo.

Outro exemplo, em sentido oposto, é dado pelos documentos do Movimento ou por análises feitas por teóricos ligados a ele, que reportam a fragmentação os desentendimentos entre assentados e liderança a um recuo na consciência do assentado, que estes não assimilariam satisfatoriamente as lições e as experiências aprendidas durante a ocupação e o tempo de acampamento (CALDART, 2004; CONCRAB, 2004).

Alguns dos teóricos que estudam a ação do MST dentro dos assentamentos reportam a fragmentação e a reprodução de relações assimétricas a razões culturais, considerando tanto as características culturais dos participantes do Movimento quanto do 
próprio MST. Nessa direção, alguns autores vão analisar os conflitos e contradições encontrados em assentamentos da reforma agrária ou na relação com o movimento social como decorrentes da diferença entre os projetos de vida dos assentados e os projetos das lideranças do movimento social e de outras agências externas que interferem no assentamento, como a Igreja e o Estado (CAUME, 2002; MEDEIROS, 2003; MIRANDA, 1998; POKER, 1994).

Para Caldart (2004), que está analisando o sentido sociocultural do MST e sua importância na formação de um novo sujeito social, o Sem-Terra, muitas vezes a experiência obtida na luta pela terra não é incorporada, não causa uma ruptura em alguns padrões culturais do partícipe do Movimento, que acaba retornando a um padrão de tradição cultural anterior ao da luta quando é assentado.

Vasquez (2002), estudando as relações dentro de um assentamento em Sumaré, ressalta que as diferenças pessoais, inclusive de objetivos dentro do movimento de luta pela terra, existiam antes e durante todo o processo de luta social, mas eram diminuídas e apaziguadas por um discurso religioso genérico, maleável o suficiente para ser interpretado por cada um segundo seus objetivos particulares. Portanto, desde a fase de acampamento, existiam objetivos e motivações pessoais diversas, que ficavam diluídos em função do objetivo maior que era a conquista da terra, mas que se explicitaram posteriormente.

Para Sigaud (2005), quando o sem-terra entra para o movimento social, participa de uma ocupação e passa a compor um assentamento, essa ocupação de terra e a possibilidade de se tornar um assentado são vistas como uma alternativa para se ter uma vida melhor, e não como uma tomada de consciência ou uma "conversão à luta", como a entrada no acampamento é visto pelos militantes. 
D`Incao e Roy (1995), estudando uma associação de assentados ligados a um movimento social, constataram o mau funcionamento das instâncias coletivas e de discussão e tomada de decisão, e a presença de um autoritarismo baseado nos laços de dominação e servilismo.

Os autores vão explicar as relações assimétricas dentro de movimentos sociais progressistas como um comportamento aprendido nas relações sociais prévias à entrada do indivíduo no Movimento e que tem tendência a se repetir. Na verdade, segundo os autores, há uma tensão entre o desejo de escapar da subserviência e os padrões internalizados de submissão (D’INCAO; ROY, 1995).

Gohn (2000) aponta a presença de elementos típicos da esquerda tradicional como tendo sido mantidos na estrutura organizacional do MST, como a constituição da direção a partir da seleção dos melhores militantes, a articulação do Movimento dos Sem Terra com outras lutas classistas, a responsabilidade dos dirigentes na condução das massas, já que essas têm dificuldade de se organizarem em termos políticos. Assim, os "erros básicos" da esquerda seriam repetidos no MST, tal como desconsiderar o peso da tradição e dos costumes entre o campesinato brasileiro, e a tentativa de se implantar novas formas de trabalho, que desconsideram esses costumes, porque são coletivizantes.

A questão da disputa entre os modelos de organização coletiva versus a individual é um ponto bastante discutido entre os teóricos, inclusive dentro do próprio MST. Segundo diversos autores que estudaram a questão da coletivização da produção, essa proposta também contribuiu para levar a um embate entre boa parte dos assentados, e a liderança do Movimento. Hoje, segundo João Pedro Stédile (STÉDILE; FERNANDES, 1999), a maior parte da base social do MST é de "individuais", isto é, assentados que produzem de forma familiar. 
Zimmermann (1994), analisando assentamentos no Rio Grande do Sul, sugere que a desconsideração das características culturais dos assentados, e a rotulação feita pelo MST e por técnicos do poder público dos projetos diferentes do padrão do movimento social em "individualistas", leva a conflitos entre o projeto "coletivo" do MST e o projeto "comunitarista" dos assentados, baseado em suas tradições culturais. Segundo a autora,

[...] o primado do 'coletivo' e de outras formas modelares acaba por desrespeitar o ritmo de aprendizagem e a conduta democrática de convivência que, juntamente com o trabalho de formação teórica, atuam como sustentáculos do crescimento conjunto da consciência política. (ZIMMERMANN, 1994, p. 222/223).

Entre as conclusões a que chegou Schreneir (2002) em sua pesquisa, está a de que as famílias cooperadas ou associadas realmente têm uma melhor qualidade de vida e melhor retorno financeiro que as famílias que produzem de forma individual (familiar). Além disso, têm maior capacidade política, no sentido de continuarem o apoio às ações de ocupação e de criação de novos assentamentos, bem como tem maior efetividade na demanda por melhorias e serviços no próprio assentamento.

$\mathrm{Na}$ verdade, as formas de organização de assentamentos preconizados pelo MST foram se alterando com o tempo, em função das próprias reflexões realizadas internamente sobre a questão individual versus coletivo. Essas reflexões foram em grande parte motivadas pelas experiências ocorridas nos assentamentos existentes. Assim, os modelos de organização de assentamento incentivados pelo MST passaram de formas baseadas exclusivamente em propriedade da terra e produção coletiva, para formas associativas, onde 
a propriedade da terra é individual, e o trabalho é coletivo, até chegar nessa forma de hoje, que procura combinar parte do trabalho e da posse da terra coletivos com uma parte de individual (BRENNEISEIN, 2002; GOHN, 2000).

Para Brenneisein (2002), o MST é paradoxal. Por um lado, sua existência e atuação são essenciais para o avanço da democracia na sociedade brasileira, que é extremamente desigual, e sempre esteve marcada pelo patrimonialismo, pelo autoritarismo, por relações históricas de dominação, servilidade e clientelismo, em especial no campo. Por outro lado, para a autora, essas relações autoritárias e clientelistas insistem em subsistir, reproduzindose dentro do próprio MST, limitando a democratização das relações no campo.

Vários fatores contribuiriam para a reprodução interna de mecanismos de dominação: a desqualificação das formas tradicionais de organização do campesinato, vistas como individualistas; uma busca de hegemonia do pensamento político; o centralismo democrático; o uso da força de persuasão para induzir a base a realizar uma tarefa ou ação já pré-determinada; uma relação confusa dos técnicos contratados ou do Estado com as lideranças do MST; a arregimentação de jovens diferenciados dos demais agricultores para exercer a militância (BRENNEISEIN, 2002).

Cabe ainda ressaltar que a postura da base (assentados e acampados) também é paradoxal, segundo a autora. Se por um lado eles tendem a reproduzir relações de dominação semelhantes àquelas nas quais foram socializados, ou seja, relações de mando e obediência, e muitas vezes inclusive pedem por essas relações; por outro lado eles resistem à dominação imposta, principalmente através do que ela vai chamar de mecanismos de resistência cotidiana, ou seja, pequenos atos diários, que de uma maneira velada, se opõem ao que lhe é obrigado, como fazer "corpo mole", pequenas sabotagens, etc. Muitas vezes, os conflitos e cisões que se manifestam dessa forma velada e cotidiana, são ignorados e 
protelados de tal forma que não conseguem mais serem contornados ou resolvidos, causando uma ruptura entre base e liderança (BRENNEISEIN, 2002).

Caume (2002), usando Foucault e Bordieu como referenciais teóricos, conclui que o assentamento, como todo espaço social, é permeado por contradições, questionamentos, interesses opostos ou semelhantes que se re-arranjam e se aglutinam sob certas circunstâncias. A partir de uma compreensão das relações de poder que privilegia os aspectos relacionais, explicita que os assentamentos são espaços em disputa, e que os assentados não se comportam de forma passiva frente às várias agências (igreja, movimento social e Estado) que disputam a hegemonia sobre o projeto de assentamento. Todos esses atores tentam regulamentar o modo de vida do assentado, procurando adaptá-lo ao seu projeto político.

$\mathrm{O}$ autor conclui que a assunção de atividades técnicas por parte de algumas lideranças do MST, ou de assentados ligados a estes, aprofunda mais ainda a cisão entre liderança e base, ao criar duas categorias de participantes do movimento social, um deles que tem um saber-poder técnico que o outro não tem. Além disso, a leitura "científica" da realidade feita pela liderança desqualifica o saber tradicional, não científico, possuído pelo assentado.

Segundo Schreiner (2002), a vivência coletiva do acampamento era uma necessidade para a sobrevivência de todo o grupo. A própria noção de igualdade, que informa toda a ação de ocupação e de acampamento, é uma reação coletiva à desigualdade socialmente engendrada. Já no assentamento, a necessidade de uma organização coletivista não se faz sentir de forma tão contundente e imediata. Outrossim, há a entrada do assentamento e dos assentados na lógica do mercado, e um forte desagregador passa a ser o trabalho medido e mediado pelo fator mercadoria. Segundo o autor, o assentamento e o 
movimento social vivem entre a utopia de não ir ao mercado e a subordinação perversa a este (SCHREINER, 2002).

Autores ligados ao Movimento vão pontuar a tensão existente na identidade do assentado, entre ser alguém em luta, ao mesmo tempo em que se é um "empresário social" (CALDART, 2004, p. 136). Segundo a autora, há um conflito não resolvido entre a lógica que o MST busca, e a lógica capitalista, e ao exercer sua atividade de produtor rural, o assentado se insere em uma atividade econômica submetida à lógica capitalista.

Caldart (2004) pontua essa tensão existe dentro do próprio Movimento, como decorrencia de sua opção de atuar tanto nos acampamentos quanto nos assentamentos, o que acarretou que coexistissem dentro do MST duas lógicas organizativas diferentes: a lógica que rege um acampamento, e a lógica que rege um assentamento.

A presença do MST no assentamento, e sua tentativa de construir alternativas, inevitavelmente obriga que o Movimento tenha que ter contato/negociar com uma lógica diferente. Como pontua Caldart (2004), os assentados pertencentes ao MST têm que lidar com a dificuldade de participarem de uma "empresa social", inserindo-se em uma atividade econômica submetida à lógica capitalista, conflitante com a lógica do que busca o Movimento.

Cabe lembrar que as relações que se estabelecem no assentamento são influenciadas pela concepção de organização que se tenta implementar, bem como pelo projeto político da liderança para aquela comunidade.

Segundo Caldart (2004), o MST envidou vários esforços no sentido de fomentar no assentamento o mesmo sentimento de comunidade, mobilização e união existente na época do acampamento. A estratégia básica utilizada, na tentativa de organizar os assentados, foi uma estratégia centrada nos aspectos produtivos, a partir de uma organização coletiva da 
produção, o que é congruente com uma leitura marxista ortodoxa da constituição dos sujeitos e de suas relações.

A esperança era de que o trabalho coletivo funcionaria como uma estratégia de aprendizado para o crescimento na consciência que traria a superação do capitalismo, sendo mais importante, nesse sentido, até do que a própria conquista do assentamento em si (STÉDILE; FERNANDES, 1999). Além disso, há uma clareza por parte do movimento social de que a reforma agrária não é somente dividir a terra, pois a tendência é de que a exclusão e a expulsão para a cidade, que criou o grande contingente de sem-terra, voltem a se repetir, por falta de condições de permanência na terra. Nesse sentido, a continuidade da mobilização e da luta após o assentamento é essencial para que os assentados tenham acesso a crédito produtivo, à educação, à moradia, aos demais serviços sociais e créditos necessários para sua manutenção como produtor rural (SCHREINER, 2002).

Segundo Stédile, um aspecto central nessa proposta é a compreensão de que a coletivização permitiria uma divisão do trabalho, forma tecnicamente superior (STÉDILE; FERNANDES, 1999). A divisão de trabalho é vista como uma evolução natural do desenvolvimento das forças produtivas, e importante ao permitir a especialização, o que melhora a qualidade do trabalho e facilita um avanço técnico (STÉDILE; FERNANDES, 1999). Assim, a divisão de trabalho é necessária para que a produtividade possa aumentar e o camponês possa evoluir na consciência, porque:

a) o camponês precisa compreender que só a divisão do trabalho vai aumentar a produtividade e, portanto, aumentar a renda e o bem-estar; 
b) só a divisão do trabalho vai permitir elevar a sua consciência social de camponês individualista para um sujeito que percebe que é apenas mais um no sistema social. (STÉDILE; FERNANDES, 1999, p. 98).

Tal leitura permite entrever uma visão negativista a respeito do camponês, que o consideram como individualista em função de sua tradição familiar de organização social e de trabalho (MARTINS, 1995; POLETTO, 1997).

De acordo com Martins (1995), a posição doutrinária leva alguns grupos de esquerda a enxergar uma inferioridade política no camponês, em detrimento do operariado urbano e rural, este sim capaz de compreender seu antagonismo com o capital e a luta de classes, e realizar a revolução. O camponês, como pequeno proprietário, seria afeito às tradições e defensor da propriedade privada.

Para Poletto (1997), dois pressupostos balizaram a visão que se tinha do camponês no início dos trabalhos que culminaram com a criação do MST e que levaram à opção pela coletivização na proposta de construção do assentamento: “(1) a direção do processo revolucionário não pode ser dos camponeses, e sim dos operários; (...) (2) a propriedade privada faz do camponês um pequeno-burguês.” (POLETTO, 1997, p. 36). Os camponeses teriam assim uma menor capacidade revolucionária, bem como uma inferioridade em suas formas de organização baseadas no trabalho familiar, por serem individualistas, afeitos à tradição e fechados a propostas de organização alternativas.

Assim, alguns estudos de orientação antropológica vão analisar os desencontros pós-assentamento reportando-os a uma leitura das lideranças do movimento social que desqualificam a cultura organizacional tradicional camponesa, em especial sua forma de se organizar comunitariamente através de redes de ajuda mútua familiares. Em que pese o fato 
de que boa parte dos assentados tem uma origem urbana, sendo a geração seguinte à que foi expulsa da área rural, tal forma de solidariedade subsiste em seu grupo cultural, em função de alguns elementos da cultura camponesa mantidos entre as famílias pobres da área urbana (BRENNEISEIN, 2005; TURATTI, 2005).

Moura (1991), em um estudo sobre o campesinato sertanejo e sua relação com a política, coloca que a organização de vida do camponês brasileiro está eminentemente baseada em uma estratégia familiar de sobrevivência e reprodução. Segundo a autora, em momentos de crise agudos, como o de privação de terra e comida, o camponês opta por soluções coletivas, e nos tempos "normais" de reprodução social, opta por táticas familiares de reprodução. Tal sistema é regulado por uma série de compromissos e normas simbólicas, que têm por base a reciprocidade.

As (crises agudas) parecem suscitar no campesinato as soluções comunitaristas, ao passo que o tempo "mediano" da reprodução social suscita soluções de tipo familiar, entendendo-se por isto as famílias produzindo a vida individualmente, uma em relação à outra. Não se encontra nas primeiras o comunismo germinando nem no segundo o individualismo nascendo. Em ambos os casos, a solução familiar predomina, sendo que nas primeiras tem-se conjuntos de famílias buscando a superação em grupos de entre-ajuda econômica, política e jurídica comunitária, ao passo que na rotina tem-se as famílias agindo de modo predominantemente autônomo, sem que estejam excluídas totalmente as soluções socializadas. (MOURA, 1991, p. 8). 
O assentado de reforma agrária, participante do movimento social, comunga dessa forma de organização da vida e de produção que têm como referência a família. Segundo Martins (2003, p. 55):

O sujeito, portanto, da reforma agrária brasileira tem um núcleo basicamente familiar, e de família extensa. Abrange mais de uma geração e de modo algum pode ser pensado como uma família nuclear constituída pelo casal e pelos filhos menores, como curiosamente estimam até mesmo agentes de mediação profundamente envolvidos na luta pela reforma agrária. A família que está na cabeça de acampados e assentados é uma instituição ampla e complexa e nem mesmo se limita a parentesco de sangue. É uma rede de direitos e deveres referidos às obrigações dos vínculos de sangue e também dos vínculos sagrados da afinidade e do parentesco simbólico. Isso inclui até mesmo a velha figura do agregado e protegido.

Moura (1991) conclui suas reflexões pontuando que o camponês brasileiro, com seus costumes e sua cultura, não é nem um segmento de práticas revolucionárias, nem de conservadoras. Segundo a autora, rotulá-lo em um desses pontos é imobilizar o olhar sobre uma realidade que é complexa e multifacetada, o que implica em não compreendê-la em toda a sua dinâmica, com as suas contradições e conflitos.

Ainda sobre a dinâmica social dentro do assentamento, é essencial comentar um outro elemento que tenciona ainda mais as relações entre liderança do movimento social e a base: a presença dos técnicos estatais. Brenneisein (2005) vai considerar a relação dos 
técnicos estatais com o MST como simbiótica, sem, no entanto, explicitar o que levaria à construção dessa relação com essas características. Essa simbiose, segundo a autora, se evidenciaria no apoio dos técnicos estatais aos projetos aprovados pela liderança do MST, na delegação da seleção das famílias a serem assentadas à liderança do Movimento, no suporte em ações consideradas autoritárias ou impopulares.

Zimmerman (1994), em uma pesquisa realizada no final dos anos oitenta, relata uma constatação parecida: o apoio dos técnicos da agência estatal de assistência técnica aos projetos propostos pelo MST, em especial os de coletivização da produção ou de parte dela. D’Incao (2000, p. 65) vai falar na figura do “técnico-militante”, que é o técnico de esquerda que comunga dos mesmos princípios que balizam a ação do movimento social.

Para Brenneisein (2005), tal postura por parte dos técnicos, que passam a fazer parte do processo de negociações antes mesmo da instalação definitiva do assentamento, somente acirra os conflitos nos assentamentos, e contribui para aprofundar ainda mais o processo de fragmentação constatado após a conquista da terra. 


\subsection{O MST e as propostas para organização de assentamentos}

"A construção do ser coletivo [deve ser] combinada com a possibilidade da livre emergência das questões da subjetividade de cada pessoa.” (MST, 2005, p. 164)

Do material levantado durante o trabalho de campo, três falavam especificamente sobre a atuação do MST no assentamento, a cartilha "Novas formas de assentamentos da reforma agrária: a experiência da Comuna da Terra", produzida pela CONCRAB (Confederação Nacional das Cooperativas de Reforma Agrária do Brasil), a apostila "O que levar em conta para a organização do assentamento, produzido pela ANCA (Associação Nacional de Cooperação Agrícola), e o texto "Idéias para um novo modelo de reforma agrária 'Comuna da Terra"”, produzido pelo MST, sendo esses dois últimos de circulação interna. Todos essas publicações nos foram fornecidos pela liderança regional do MST e, segundo elas, serviram de balizamento para a construção da proposta que foi colocada em prática no PDS Sepé Tiaraju.

O que se pode perceber nos documentos publicados pelo MST é que o que ele objetiva com suas ações não é somente a conquista de terra para aqueles que não a possuem, mas, mais do que isso, é a construção de um novo mundo e de um novo sujeito, o qual eles vão chamar ora de "um novo ser", ora de "um novo homem e uma nova mulher" (ANCA, 2002; CONCRAB, 2004; MST, 2001). 
Esse novo mundo, do qual o assentamento deve ser um vislumbre, precisa ser constituído sobre novos valores, livre da opressão e do autoritarismo, sem discriminação e com justiça social (ANCA, 2002; CONCRAB, 2004).

Para o MST, valores humanistas e socialistas são aqueles que colocam a transformação do indivíduo e sua liberdade em primeiro lugar, considerando que o homem não é um ser isolado, mas é um ser de relações sociais, relações essas que devem visar "a produção e a apropriação coletiva de bens materiais e espirituais da humanidade, a justiça na distribuição desses bens e a igualdade da participação de todos nesse processo" (MST, 2005, p. 164).

O reflexo disso em relação à organização e funcionamento de um assentamento se materializa na preocupação explicitada nos documentos do MST de que cada assentamento se constitua em uma nova comunidade, em um espaço diferenciado que proporcione aos indivíduos uma nova sociabilidade e uma vivência de reflexão e crescimento rumo a uma consciência transformada, como se pode observar nas duas citações a seguir:

Nos aspectos sócio-culturais, da mesma maneira, o princípio básico será a solidariedade, o compromisso com a democracia e a participação, com direitos e deveres iguais para todos homens, mulheres e jovens, buscando a construção do sonho e da felicidade do ser Humano, o novo homem e a nova mulher. (...) A idéia é organizar um ambiente de comunidade, estimulando a aprendizagem permanente, desenvolvendo a sociabilidade e a solidariedade em conjunto com as idéias e propostas (CONCRAB, 2004, p. 19). 
Esse espaço de convivência social deve também ser um território de resistência e de formação social e política das pessoas (MST, 2001, p. 1).

Esse espaço deve ser organizado de forma a permitir e estimular que o assentado se ocupe com atividades produtivas e sociais saudáveis. Esse tipo de vida permitirá que o assentado caminhe em direção à formação de uma consciência superior, que se traduz em novos hábitos, condutas e valores (ANCA, 2002):

O primeiro fundamento (para a organização do assentamento) é o vínculo das pessoas com o trabalho e a produção e na ocupação de parte do tempo em contato com a natureza, terra e meio ambiente e também em atividades sociais e culturais, em coisas saudáveis que trazem o sonho e a perspectiva da dignidade e elevação da consciência social na defesa dos seus direitos como cidadão. Esse é o primeiro passo na organização que permitirá avançar na consciência política (MST, 2001, p. 3).

O desejo é de que as pessoas construam uma nova sociabilidade dentro do assentamento, com a criação de novos laços afetivos e sociais, com companheirismo e solidariedade na relação entre as pessoas, com uma busca pela igualdade com respeito às diferenças, e com a construção de uma vida comunitária e coletiva (ANCA, 2002; CONCRAB, 2004).

Há uma preocupação bastante grande com a reprodução de relações reificadas dentro da própria família, em especial no que diz respeito às relações de gênero. No assentamento, as relações devem se configurar de forma a garantir os direitos e a dignidade 
de mulher, em pé de igualdade com os homens. Assim, o MST recomenda que a titulação seja feita de forma conjunta, em nome do casal, visto que

[...] tal atitude ajudará a família a melhor se planejar e, em muitos casos, ajudará a romper com alguns vícios como o autoritarismo, machismo, que não ajudam na construção de uma família saudável, com novos valores e liberta da opressão. O que me vale libertar-me da opressão do fazendeiro se em casa, junto a família, a submeto a pressões ainda piores, como o medo, a violência, a brutalidade (ANCA, 2002, p. 11).

A preocupação com a participação feminina aparece de forma recorrente nos textos. Além de se sublinhar a importância da participação da mulher, defende-se a criação de mecanismos no assentamento que garantam essa participação, como a escolha de um coordenador homem e uma mulher para a direção de cada núcleo, a titulação da terra no nome de ambos, a participação igualitária das mulheres em assembléias, discussões e instâncias diretivas de planejamento. Para o MST “[...] a construção da nova sociedade começa também com a participação da mulher.” (ANCA, 2002, p. 12).

Isso reflete uma preocupação com a igualdade nas relações interpessoais, com que o assentado não reproduza a opressão com a qual estava acostumado, em virtude do processo de desumaninazão e de degradação humana a que estava submetido antes de entrar na luta. Assim,

Nos aspectos sócio-culturais, da mesma maneira, o princípio básico será a solidariedade, o compromisso com a democracia e a participação com 
direitos e deveres iguais para todos, homens e mulheres, buscando a construção do sonho e da felicidade do ser humano (MST, 2001, p. 4).

Há a percepção de que há uma mudança no comportamento e na consciência do indivíduo depois que ele é assentado, compreendida, nos textos estudados, como sendo de responsabilidade do movimento social, que não criou condições satisfatórias para o avanço daqueles assentados.

É costumeiro ouvirmos a frase de que quando a pessoa é assentada vira 'pelego'. Isto reflete a nossa incompreensão sobre o que de fato ocorre na 'cabeça' destes assentados. Este recuo na consciência não é de responsabilidade única do assentado. De fato, os principais responsáveis por isso somos nós, que não tivemos a capacidade de organizar o assentamento de tal forma que as pessoas que lá vivem e produzem continuem a crescer na consciência. A estrutura social (assentamento) que agora é o local onde estas pessoas passam a viver, não cria condições para este avanço (CONCRAB, 2004, p. 40).

Nesse sentido, o MST frisa a necessidade de se dar uma atenção maior à formação da liderança e da militância do assentamento, a fim de que elas não atuem como 'freios' do desenvolvimento das pessoas, pois

[...] pretende-se que as pessoas tornem-se donas do seu destino, o que poderá levar a um choque com o método autoritário e centralizador, 
típicos de lideranças vindas de uma base camponesa (ANCA, 2002, p.18).

A solidariedade é incentivada em vários momentos, seja para com os companheiros de assentamento e de luta, seja para com aqueles que são de fora do assentamento, tanto os participantes de outros movimentos de luta da classe trabalhadora, quanto para com os moradores da cidade em geral.

Devemos também estimular ações para a sociedade, onde busquemos ser solidários com ela, através da prática de doação de produtos e trabalho voluntário em estabelecimentos públicos e praças (ANCA, 2002, p. 23).

A relação com a cidade não está centrada unicamente na questão da solidariedade, mas há uma intenção em massificar a luta e em mostrar para a sociedade que o assentamento é algo positivo, que traz benefícios não só para o assentado, mas também para a cidade. Há uma preocupação em lograr o apoio não só dos amigos do MST, que são aqueles que o apóiam em suas ações, como da sociedade em geral:

[...] celebrar as colheitas significa também celebrarmos a vida. Para isso, convidar amigos do município e região e divulgar que aquela comunidade está cumprindo com a sua função social, mostrando para a sociedade que vale e pena investir em Reforma Agrária (ANCA, 2002, p. 22 e 23).

Os assentamentos devem se constituir em novos territórios da luta social, demonstrando a viabilidade da reforma agrária e transformando-se em 
referência para o desenvolvimento de um outro modelo produtivo. (CONCRAB, 2004, p. 13).

A questão da subjetividade aparece pouco, em geral associada às relações interpessoais, à organização do espaço segundo o desejo dos assentados, e à luta pela terra. O termo só aparece explicitamente duas vezes, uma com um sentido positivo, outra com um sentido negativo. No primeiro caso, ele aparece associado às emoções e à necessidade de se manter viva a memória da luta:

Em nossas vidas é muito comum desconsiderarmos os aspectos subjetivos, como as emoções. O pragmatismo da vida na agricultura nos leva a valorizar apenas os aspectos imediatos da vida. Assim, os locais históricos de nossa luta caem no esquecimento, a celebração dos frutos do nosso trabalho e da nossa luta são desconsiderados. Acender a chama da memória em cada um dos assentados é nosso dever. Reavivá-la, alimentála com novos sonhos faz parte de nossa política (ANCA, 2002, p. 22).

No segundo caso, faz referência a uma tendência ao individualismo do camponês brasileiro:

[...] Estes camponeses, por organizar o seu processo produtivo de forma familiar (sem divisão técnica do trabalho) e com base na propriedade privada, tendem a constituir uma visão de mundo subjetivista e oportunista (ANCA, 2002, p. 7). 
Caume (2002) vai pontuar que quase não se faz referência à subjetividade nas publicações do MST. A primeira vez que se tratou desse tema foi no ano de 1998, no Caderno de Formação “A vez dos valores”, de Ademar Bogo (BOGO, 1998).

Segundo esse autor, os teóricos internos do Movimento disputavam um entendimento/compreensão sobre o trabalho coletivo, sendo que a consideração dos aspectos ligados à dimensão subjetiva, como "novos valores", “novas formas de convivência social" (CAUME, 2002, p. 160) eram defendidos por Bogo. O modelo proposto por este ficou em segundo plano por anos, quando se implementaram modelos com um viés mais estruturalistas, propostos por outros teóricos do movimento, que enfocavam mais a cooperação com relação às questões produtivas (CAUME, 2002; SCHEREINER, 2002).

Se a partir de 1998, o MST passou a considerar um pouco mais a questão da subjetividade, nos textos estudados neste trabalho, como podemos ver acima, ela ainda está sub-representada em comparação com as questões produtivas (ver tabela 1).

Com relação à produção, o trabalho coletivo é a forma preconizada pelo MST para se chegar a formas aprimoradas ou superiores de consciência, para superar o individualismo identificado como a tendência do camponês brasileiro. Segundo os textos estudados, esse trabalho coletivo pode e deve se dar contemplando as várias áreas de atividade do ser humano, não somente a produção, estimulando "a cultura da socialização dos meios de produção, desenvolvendo a cooperação em todos os aspectos, enfrentando, assim, o individualismo." (CONCRAB, 2004, p. 13).

Cabe ao MST aproveitar essas circunstâncias e propor formas de cooperação que ajudem as famílias a viabilizar a subsistência e a 
produção para o mercado. Evidentemente que as formas de cooperação a serem propostas poderão abranger outros campos das necessidades humanas, além do econômico (ANCA, 2002, p. 16).

Também há uma preocupação a que se chegue de forma gradativa ao que eles chamam de coletivo pleno, partindo da coletivização de partes dos processos, "caminhando ao longo do tempo para a coletivização total das atividades econômicas do núcleo" (ANCA, 2002, p. 16).

Esses coletivos devem se constituir de forma a respeitar cada uma das pessoas, suas afinidades, seus laços afetivos, suas amizades, seu sentimento de pertença familiar, sua identificação étnica, cultural, política, de origem ou religiosa (ANCA, 2002).

Há uma preocupação com a participação social organizada, seja no assentamento, seja fora dele, considerando que a convivência com o outro é fonte de desenvolvimento da consciência, pois a consciência social é "produto do convívio e da participação social, desenvolve-se naturalmente na medida em que se estimula os aspectos do convívio e da participação." (ANCA, 2002, p. 7).

Atualmente, visando contemplar o desejo muitas vezes colocado pelos assentados de ter uma área de trabalho individual, ou seja, onde o assentado trabalhe com sua família de forma autônoma, o MST tem procurado experimentar formas alternativas de assentamento, que procuram respeitar as características locais e que seguem esse princípio parte coletivo, parte individual. O modelo adotado e defendido pelo MST para o Estado de São Paulo é o modelo de Comuna da Terra (CONCRAB, 2004).

A Comuna da Terra, ou "comunidades de economia camponesa", foi a forma encontrada pelo MST no Estado de São Paulo para tentar combinar formas individuais de 
produção com formas coletivas (CONCRAB, 2004). Os fundamentos básicos para a constituição de uma Comuna da Terra são o vínculo das pessoas com o trabalho e a produção, o caráter social da propriedade da terra, a matriz de produção com base na agroecologia, a cooperação e a solidariedade em seus diversos aspectos (econômico e sócio-cultural) e o estímulo ao desenvolvimento sócio-cultural das famílias.

A forma legal encontrada para regulamentar esse tipo de assentamento, no caso de terras federais, foi o PDS (Projeto de Desenvolvimento Sustentável). Essa modalidade de assentamento foi criada pelo governo federal através das portarias INCRA $n^{\circ} 477$ de 04/11/1999 e n 1032 de 25/10/2000, após um trabalho interministerial do MDA- INCRA com o MMA (Ministério do Meio Ambiente), pensando na regularização da utilização das terras em área Amazônica (MDA, 2000). A titulação da terra nessas áreas deveria se dar preferencialmente de forma coletiva, mas previa também a titulação individual. Os PDS visam "conciliar o assentamento de populações não tradicionais, em áreas de interesse ambiental, com a promoção do desenvolvimento sustentável” (MDA, 2000, p.7).

É preconizada a posse coletiva da terra, e não a propriedade, com a não-titulação do assentado, mas com a garantia de direito sucessório:

A terra deve ser um bem comum e não propriedade privada. Deve estar nas mãos dos trabalhadores para cumprir sua função social, garantir o trabalho, as pessoas e a produção de alimentos para alimentar a humanidade, preservar o meio ambiente e a natureza. Não deve ser objeto de especulação imobiliária, portanto deve continuar sendo de propriedade pública estatal, com concessão de uso aos trabalhadores por tempo indeterminado, sem direito à venda (MST, 2001, p. 3). 
Uma das características de uma Comuna da Terra é sua proximidade à área urbana, visando uma facilidade de escoamento da produção, e a produção em áreas menores, de forma intensiva, com a possibilidade de produção de produtos não-agrícolas.

O segundo ponto importante dessa idéia do rururbano, é que podemos, numa área bem menor que no modelo utilizado nos assentamentos rurais atual, assentar muito mais famílias. Ou seja, entre dois a quatro hectares de terra, garantir a subsistência das pessoas, e também possibilitar uma renda, desenvolvendo a produção de forma planejada e diversificando a exploração racional dos recursos naturais [...] (MST, 2001, p. 2).

Além disso, a Comuna da Terra procura preservar as características urbanas dos assentados, seja sob o aspecto da cultura, seja para manter a proximidade dos benefícios dos centros urbanos, visando uma massificação da luta e uma "recampesinação" de parte da população que está nas periferias dos centros urbanos (CONCRAB, 2004).

Se propusermos a essas famílias que agora vivem nos grandes centros urbanos para irem para uma região distante, quinhentos ou seiscentos quilômetros, elas terão dificuldade de ir, mas se a distância for de oitenta ou cem quilômetros certamente ficarão interessadas (MST, 2001, p. 2). 
Segundo tal visão, essa forma de organização de assentamento tem a vantagem de levar os avanços sociais e as vantagens da urbanização, como saúde, educação, água, energia elétrica ou outros serviços urbanos aos que estavam à margem desses benefícios.

Certamente, na medida em que conquistamos a energia elétrica e a água encanada, avançamos na humanização das pessoas. (...) precisamos também insistir em aspectos que garantam esta caminhada civilizatória (ANCA, 2002, p. 23).

A questão da cultura também é bastante valorizada, incluindo a intenção de se valorizar alguns aspectos da cultura urbana que já foram apropriados pelas famílias que aí viveram e que estão assentadas nas Comunas da Terra.

Existem muitos jovens nas Comunas e estamos trabalhando a questão da cultura de forma bastante intensa, para que a Comuna da Terra seja um espaço de formação e desenvolvimento cultural. A interação da cultura camponesa com a cultura urbana, como o hip hop tem sido um dos pontos forte destas experiências (CONCRAB, 2004, p. 36).

A preocupação com a cultura e com a formação integral dos indivíduos aparece em vários momentos, não só nos documentos que discutem especificamente o assentamento segundo o modelo de Comuna da Terra, mas também na cartilha que trata da organização do assentamento segundo um modelo geral (Cartilha "O que levar em conta..."). Nesse documento, são dadas várias sugestões para se fomentar a realização de atividades que além 
de formar, divirtam e ocupem o tempo de forma "saudável", como a criação de bibliotecas para estimular a leitura, a criação de brinquedotecas e parquinhos infantis para estimular o desenvolvimento e a coordenação motora das crianças, a realização de festivais de poesia, de música, a organização de festas típicas rurais (junina, reisado, etc.), de grupos de teatro, de fantoche, de rádio comunitária, entre outros:

\footnotetext{
A biblioteca deverá ser organizada ainda no acampamento, como forma de estimular as pessoas ao hábito de leitura. Organizando num local os materiais do MST, arrecadar junto aos amigos e colaboradores, livros e outras publicações, de maneira que todos os materiais fiquem à disposição das famílias. (...) Esta prática no acampamento refletirá nas discussões sobre a futura biblioteca do assentamento. (ANCA, 2002, p. 20).
}

A valorização da educação, do esclarecimento, a importância do fortalecimento da auto-reflexão, bem como o estímulo ao exercício do pensamento engajado e crítico também pode ser percebida em textos teóricos da área de educação, produzidos pelo Movimento e não estudados no presente trabalho, mas que apresentam uma ênfase na educação como fator de conscientização do homem e de caminhada rumo ao seu esclarecimento e autonomia, o que está em consonância com a visão adorniana de que é a educação um dos caminhos para a desbarbarização da sociedade e para fomentar a autonomia do sujeito (ADORNO, 1986).

Uma outra preocupação presente nos princípios de organização de um assentamento segundo o modelo Comuna da Terra tem relação com a ecologia. A matriz técnica e 
tecnológica que fundamenta o desenvolvimento produtivo dentro desse novo modelo de assentamento é a da produção orgânica com bases na agroecologia (CONCRAB, 2004).

As resoluções do $5^{\circ}$ Congresso do MST, realizado em junho de 2007, confirmaram essa direção a ser seguida pelo Movimento. As linhas políticas reafirmadas no Congresso dão uma ênfase na questão da agroecologia, e nos assentamentos segundo o modelo da Comuna da Terra, “a produção necessariamente passa por um novo padrão produtivo e tecnológico, na produção ecológica ou orgânica com bases na agroecologia” (CONCRAB, 2004, p. 18).

Cabe pontuar que a produção parte individual/parte coletivo da Comuna da Terra é apresentada como proposta de um novo modelo de assentamento, que busca contemplar o desejo do trabalhador assentado de ter seu lote sozinho, onde trabalha com a sua família, e ao mesmo tempo permitir que ele tenha um espaço onde vai produzir de forma coletiva com outros assentados, servindo para propiciar uma experiência coletiva de trabalho (CONCRAB, 2004; MST, 2001).

O que se pode observar, no entanto, é que tal forma de trabalho (parte individual, parte coletiva), apresentada como novidade, já foi tentada em outras oportunidades pelo próprio MST. Algumas dessas tentativas foram estudadas nos anos oitenta por Zimmerman (1994), sendo que o modelo que contemplava parte individual parte coletiva era chamado pelo MST, pela Igreja e pelos entes estatais de "semi-coletivo" (ZIMMERMAN, 1994).

Zimmerman (1994) pontua que essas experiências foram fortemente influenciadas por fatores como a heterogeneidade das características culturais dos participantes; diferenças com relação à disponibilidade da força de trabalho familiar, que influenciava grandemente no momento de divisão dos ganhos; e diferenças de nível técnico, econômico e de capitalização das famílias. A combinação desses fatores e a forma como se lidou com 
eles foi determinante para o fortalecimento da associação entre as pessoas, ou para o surgimento de desentendimentos e de dissociação.

No caso dos textos estudados, como comentamos acima, esse modelo que já é antigo é apresentado como novidade, e podemos perceber que não há uma reflexão sobre as tentativas anteriores de se implementar o modelo de semi-coletivo, e sobre o que levou essas experiências a terem sucesso ou a fracassarem, desprezando-se assim as lições que a história poderia ensinar, que segundo Stédile e Fernandes (1999), deveriam ser observadas.

Dentro do assentamento, e visando facilitar o funcionamento das instâncias coletivas de participação e de trabalho, os assentados devem estar organizados em núcleos de base, cujos coordenadores, em número de dois, se somam para formar a coordenação geral do assentamento. A participação deve se dar de forma organizada, a coordenação geral se reunindo para definir a pauta, a fim de que estas sejam comuns para todos os núcleos de base. Esse tipo de organização visa evitar o "assembleísmo", todas as discussões devem ocorrer nos núcleos de base, buscando construir um consenso, e a assembléia deve ser apenas para o referendo de propostas (ANCA, 2002).

Quanto a sua relação com o Estado ${ }^{2}$, os documentos estudados deixam entrever que esta é tensa; por um lado há a pressão e os embates, por outro lado é o Estado quem cria os assentamentos, e deve garantir as políticas públicas como educação e saúde para os assentados. Também há uma expectativa de que os agentes do Estado que prestam assistência técnica reforcem as diretrizes e princípios do MST. Assim,

\footnotetext{
${ }^{2}$ Em geral, o contato maior do MST se dá com as instâncias do Poder Executivo dos níveis municipal, estadual e federal, em especial aquelas que se encarregam da implementação de políticas públicas. Em alguns momentos, em especial no acampamento, há contato com outras instâncias do Estado, como a polícia (Poder Executivo), o legislativo (vereadores e deputados), ou o Judiciário.
} 
[...] o INCRA deverá aceitar a decisão interna das famílias, consolidando a organização dos grupos de base e seus acertos e combinações internas sobre o funcionamento do futuro assentamento (ANCA, 2002, p. 10).

Cabe ressaltar que a assistência técnica deverá estar voltada para garantir todo esse processo, que sua missão, além de solucionar os impasses tecnológicos existentes, será também o organizador e o formador das comunidades. O corpo técnico deverá estar convencido da proposta deste novo jeito de organizar o assentamento e atuar para sua consolidação (ANCA, 2002, p. 16).

Além disso, há a orientação para que se realizem trabalhos que antes eram considerados típicos do Estado, como o trabalho de topografia/ agrimensura, inclusive com a criação de empresa para participar de licitação pública, a fim de garantir o controle político sobre o projeto de organização do assentamento e o corte da área:

No Espírito Santo, o MST organizou uma empresa de topografia que participa das licitações do INCRA para esse trabalho em novos assentamentos. Em todas as licitações que o MST/ES participou, ganhou a concorrência e está executando o corte da fazenda desapropriada. [...] a forma de realizarmos esse controle sobre a elaboração e a execução do corte da área varia de acordo com a realidade estadual. Mas o princípio permanece: temos de garantir o controle político sobre o projeto de assentamento e do corte da área pois ele será o motor das discussões internas no acampamento e a ferramenta para garantir o que foi discutido 
e aprovado na nossa base. Como também a tendência será, cada dia mais, o INCRA terceirizar estes serviços. (ANCA, 2002, p. 9).

Se por um lado o MST afirma a necessidade de participação de todos os assentados nas instâncias coletivas, por outro lado, os textos do MST apresentam uma visão do camponês como alguém que tem que ser transformado, sendo incapaz de decidir por si só devido à sua mentalidade individualista e atrasada, e que deve ser induzido a pensar coletivamente. Essa concepção ideológica diz que

[...] os camponeses, por serem produtores autônomos de mercadorias, não visualizam, de forma clara, seu explorador (não há patrão). [...] Por não entenderem a sua posição e situação de classe, desenvolvem uma consciência corporativa e economicista. Estes camponeses, por organizar o seu processo produtivo de forma familiar (sem divisão técnica do trabalho) e com base na propriedade privada, tendem a construir uma visão de mundo subjetivista e oportunista (ANCA, 2002, p. 07).

Essa visão é congruente com a visão de algumas correntes marxistas, que apresentam uma valorização negativa do camponês, pois entendem que a classe revolucionária por excelência é o proletariado, e que o agricultor tende a desaparecer com o avanço das forças produtivas. Aliás, nos textos estudados, a única citação teórica encontrada - de Marx - diz que "A natureza do modo de produção capitalista implica uma constante diminuição da população agrícola em relação à população não agrícola." (CONCRAB, 2004, p.7). 
Percebe-se a influencia de uma leitura simplificada de Marx, aplicando diretamente a análise que este faz do camponês francês do século XIX para o camponês brasileiro. Segundo esse entendimento, os camponeses pequenos proprietários não têm capacidade de estabelecer um elo entre si, não se constituindo como classe e não sendo capazes de se auto-representar, necessitando de uma autoridade externa para lhes conduzir (MARX, 1978). O fato de serem pequenos proprietários de seus meios de produção os coloca automaticamente em uma posição conservadora e reacionária, que necessariamente leva ao fracasso na formação da consciência política.

Como decorrência dessa leitura, a relação do MST com a organização tradicional camponesa, baseada na família, é contraditória. Nos documentos estudados, pode-se perceber, por um lado, um incentivo a divisão e organização dos núcleos respeitando-se a organização familiar, isto é, mantendo famílias que se conhecem e que têm afinidade juntas, visando facilitar a interação entre aquelas que desejam trabalhar e viver coletivamente:

[Com o sorteio em grupos de famílias] evita-se assim a dispersão das famílias que, por diversas razões, se conhecem e são amigas. [...] $\mathrm{O}$ sorteio em grupo de famílias evita que todas as famílias sejam sorteadas individualmente (ir para a "bolinha"). Esse método já demonstrou ao longo dos anos o seu fracasso e o desastre que ele cria no futuro assentamento. $\mathrm{O}$ sorteio em grupo significa para nós o primeiro passo e o potencial para as futuras formas de cooperação entre famílias, sejam elas nos aspectos sociais ou econômicos. (ANCA, 2002, p. 10). 
Além disso, entre as formas de propriedade e uso da terra que considera como cumprindo o seu caráter social, inclui a forma familiar de trabalho (CONCRAB, 2004). Por outro lado, há uma valorização negativa das formas de organização familiar, como podemos notar em uma das citações anteriores, no qual a divisão de trabalho na forma familiar é considerada como um fator de construção de uma visão de mundo subjetivista e oportunista. Além disso, se postula que o camponês não está acostumado a cooperar, em função de sua forma de divisão do trabalho familiar (ANCA, 2002, p. 7).

Recorrendo a Moura (1991), o fato de ser camponês não pode ser significado, a priori, como positivo ou negativo, como se ele fosse conservador ou revolucionário, inferior ou superior por isso. O próprio Marx, no texto supracitado, que data de 1851/1852, vai contrapor o camponês revolucionário ao camponês conservador, citando exemplos da atuação coletiva de grupos de camponeses em luta contra a dominação e por serem senhores de sua própria vida.

Segundo Martins (1997), o camponês brasileiro tem já uma tradição de cooperação econômica e de divisão de trabalho baseado em um modelo familiar. De acordo com o autor, o modelo de família para o camponês não é a família nuclear burguesa, mas é aquele que as ciências sociais denominam de família extensa, que inclui as relações simbólicas de parentesco, com uma série de deveres e reciprocidades que não se limitam aos vínculos de sangue, mas constituem uma rede extensa de sociabilidade e apoio mútuo (Martins, 2003). Ainda segundo esse autor, essas formas de cooperação são depreciadas não só pelo movimento social, mas pelos técnicos estatais que trabalham com essa população, que tentam impor formas de cooperação absolutamente estranhas à cultura do assentado, e que tendem ao fracasso, justamente por não respeitarem o tipo de coletivização que os camponeses já estão acostumados. 
De acordo com Moura (1991), o camponês se organiza de forma familiar em alguns momentos, isto é, trabalhando somente com sua família, e em outros se organiza de forma comunitarista, trabalhando ou criando coletivos que abrangem uma série de famílias. De acordo com a dinâmica e a necessidade, esses coletivos se desfazem e se refazem, sem maiores traumas.

No caso dos textos estudados, os coletivos que surgem espontaneamente, a partir desse modelo de organização, inclusive envolvendo questões ligadas à produção, são vistos pelo Movimento como formas frágeis de organização:

Os núcleos (no assentamento Dom Tomás Balduino) foram consolidados por afinidades pessoais, e isto é muito frágil, se quebram as relações, por desentendimentos, pequenas brigas, fazem com que a participação fique mais difícil no núcleo (ANCA, 2004, p. 37, itálicos no original).

Há uma preocupação de que os assentados assumam o tipo de coletividade preconizada pelo MST, que é entendida como uma forma "plena" de coletividade, associada a uma forma superior de consciência. Friza-se a importância da coletivização, em especial da terra e da produção. Segundo o Movimento, "o fundamental é a socialização dos meios de produção em algum momento de processo produtivo, não necessariamente em todo." (CONCRAB, 2004, p. 19).

Da mesma maneira, as formas de organização e de sociabilidade populares, já conhecidas ou exercitadas pelos assentados, são entendidas como proporcionando um nível muito pequeno de convivência, tendo que ser gradativamente substituídas por formas de sociabilidade aprendidas na convivência dentro do movimento social: 
arrebanhamos pessoas simples, que viviam nas comunidades rurais ou periferias das cidades, que conviviam e participavam apenas de momentos religiosos (culto), esportivos (futebol) e sociais (boteco) e com elas construímos uma nova estrutura social (acampamento) onde passaremos a vivenciar diversos níveis de participação interna [...], enfim, a conviver intensamente. Assim, estas pessoas saem de um nível muito pequeno de convivência e participação e se incorporam em uma estrutura social que proporciona e acelera estes aspectos (ANCA, 2002, p. 7).

De fato, vários autores vão pontuar que a experiência de participar de um movimento social cria uma espécie de sociabilidade nova, que lhes fornece uma oportunidade de conviver intensamente e de construir uma identidade coletiva (CALDART, 2004; MARTINS, 1997). Efetivamente, a participação em um movimento de luta pela terra proporciona uma convivência intensa e o desenvolvimento de uma participação política, com a qual os indivíduos não estavam anteriormente acostumados.

Outrossim, há que se considerar que o tipo de sociabilidade e de participação política proporcionados por esta sociedade é realmente pobre, e visa à eterna repetição do mesmo, não sendo esta somente uma característica reservada aos que vivem nas periferias da cidade e àqueles que vivem na zona rural, mas atinge, nesta sociedade, mesmo aqueles que detém os meios de produção. A relação entre os homens é mera "relação", comprometida pelo princípio do equivalente, que passa a ser modelo de toda a organização social, inclusive do próprio pensamento do homem, de sua relação consigo mesmo, e de sua relação com os semelhantes. 
Eventualmente, as pessoas pobres e as habitantes da zona rural até poderiam ter mais elementos que lhes dessem condições de escapar desta lógica. Considerando que as experiências subjetivas de desajuste e de dilaceramento é que podem deixar entrever algumas possibilidades de resistência contra essa sociedade reificada e de realização do gênero humano, aqueles que se constituem a massa dos participantes do MST, em função da própria proximidade da exclusão e da marginalidade, podem, ao refletirem sobre essa situação, se reorganizarem de forma a se contraporem ao tipo de relação pedida pelo sistema capitalista (ADORNO, 1992; GAGNEBIN, 2001). Nesse sentido, efetivamente a participação no MST proporciona e acelera esses aspectos.

O MST fala da necessidade de contemplar as diversas esferas da vida humana ao se pensar na organização de um assentamento, mas a tônica principal, segundo o que se pode perceber nos textos estudados, é dada pelas questões de produção. Um exemplo disso é a cartilha "O Que Levar em Conta Para a Organização do Assentamento", onde as questões sociais, culturais, de saúde e educacionais, entre outros, aparecem dentro do item "Elementos Complementares a Serem Considerados", ocupando seis das dezesseis páginas de texto, contra dez páginas que tratam do "Núcleo Básico da Proposta", cujas questões giram em torno da produção agrícola (ANCA, 2002).

O importante é criar na cabeça de cada pessoa o esforço do "pensar coletivamente o assentamento' e disto irmos adequando o sonho de cada um ao potencial produtivo existente e à real necessidade de planificarmos as ações econômicas (ANCA, 2002, p. 15). 
A ênfase nas questões produtivas é congruente com a visão apresentada por Stédile e Fernandes (1999), segundo a qual através da divisão de trabalho o assentado chegará a uma consciência de classe diferenciada.

Como pontua Balduino (1999), nas experiências de organização de assentamento, a forma de trabalho coletivo é essencial para que se caminhe no desenvolvimento da consciência e na direção de uma sociedade alternativa, ao possibilitar uma nova forma de trabalho e de experiência. Nesse sentido, as questões produtivas assumem uma grande importância, ao permitirem experimentar uma nova relação de produção, a coletiva, a qual os assentados não estariam acostumados.

Nesse sentido, pontuamos que a produção, mesmo no assentamento e ainda que cooperada, não está isenta das contradições advindas das relações sociais de produção do sistema capitalista, que se espraiam por toda a sociedade. Lembrando as colocações de Martins (1995), o campo brasileiro, desde seus primórdios, foi constituído segundo a lógica capitalista, com uma função bem delimitada dentro do sistema. A participação em um trabalho coletivo dentro do assentamento não se constituirá, assim, uma experiência de trabalho socialista ou "liberta", com uma lógica inversa à da mercadoria, vigente em nossa sociedade, mas inevitavelmente terá que se haver com sua inserção na lógica de mercado capitalista.

Cabe observar que há outras formas de se trabalhar a consciência, que não necessariamente essa (o trabalho coletivo). O fato de ter que ser assim, somente através dessa forma, pode criar uma série de desentendimentos com a base, solapando a possibilidade de avanço na consciência, ao criar uma relação autoritária e que coloca o assentado em um lugar de submissão, regredindo o assentado, com o seu desejo e seu conhecimento, à categoria de coisa. Além disso, se a coletivização como forma de ter uma 
experiência alternativa para contribuir no avanço da consciência e como forma de chegar a uma nova sociedade, de meio, tornar-se fim em si mesma, passa a reproduzir a racionalidade instrumental da sociedade capitalista. No nosso entender, o exercício da problematização, da discussão, da reflexão, é mais efetivo para o avanço da consciência do que a assunção de formas de trabalho pré-definidas de forma externa ao indivíduo.

Essas considerações não inviabilizam ou diminuem a importância das experiências de trabalho coletivo, muito pelo contrário, trazem à reflexão a importância de se problematizar e se refletir sobre essas experiências, principalmente para os indivíduos que delas participam, tendo em vista o todo social onde elas estão inseridas, bem como a lógica do mundo administrado com a qual inevitavelmente o trabalho coletivo tem que lidar, ao invés de elogiar a cooperação como um fim em si mesma, isenta de contradições e como a panacéia para o desenvolvimento da consciência dos sujeitos, velando assim sua real condição frente ao todo social, o que solapa suas possibilidades de fomentar uma verdadeira experiência, de levar à reflexão.

Nos textos estudados, é importante pontuar que há uma preocupação em mostrar para a sociedade que o assentamento dá certo. $\mathrm{O}$ assentamento deve mostrar para os amigos e para a região onde está inserido que está cumprindo sua função social, servindo assim de confirmação de que "vale a pena investir na reforma agrária" (ANCA, 2002, p. 23). Nesse sentido, a produção cumpre, além das funções econômicas, funções políticas e de propaganda (ANCA, 2002).

Além disso, também há uma preocupação em fazer com que a produção garanta uma renda mínima por família, a fim de se garantir uma qualidade de vida satisfatória para o assentado, fixando o homem no campo, evitando a pauperização e um novo êxodo rural (CONCRAB, 2004). 
Outrossim, há que se observar, como podemos perceber na citação acima, que há a expectativa de que o sonho de cada um dos assentados vá se adequando às questões econômicas e produtivas. Há uma preponderância dessas questões sobre os outros aspectos da vida do assentado, e estes últimos têm que se adequar à lógica e à tônica dada pela produção.

Assim, percebe-se uma visão que privilegia a questão da produção como eixo de organização do assentamento e da vida na nova comunidade, em detrimento dos outros aspectos da vida social dos indivíduos assentados, incluindo aí seus desejos, ou seja, sua subjetividade. O trabalho passa a ter um valor em si, de forma quase moralista:

A terra é para aqueles que querem trabalhar e dela tirar o seu sustento. Logo, a terra não é lugar para gente descompromissada com o trabalho e com a produção. (CONCRAB, 2004, p. 11).

Se a questão da produção é importante, pois em consonância com o pensamento marxista, o trabalho é uma categoria central e a posição nas relações sociais de produção é constitutiva da consciência, cabe lembrar que as relações de produção vigentes nessa sociedade se espraiam para o todo, impondo-se também no assentamento.

Segundo Adorno, no atual sistema, todos estão alienados. Diante do mundo administrado, a integração do indivíduo no todo e assunção deste da visão de mundo vigente, independe de sua posição no sistema produtivo, e tem como consequência que a participação em uma classe e a ocupação de um determinado lugar no sistema produtivo não garante as condições para o surgimento da consciência de classe. 
A colocação da produção como o aspecto mais importante para a organização e o desenvolvimento do assentamento é temerário por carregar consigo algo de falseamento da realidade, por investir na idéia de que submetendo os indivíduos às regras determinadas pelo potencial econômico e produtivo, com divisão do trabalho, utilizando tecnologia que permita o acompanhamento, no assentamento, das forças produtivas, e com uma pitada de cooperação entre os trabalhadores, eles irão evoluir rumo a uma consciência plena, ou pior, de que a lógica capitalista será revogada naquele espaço.

De acordo com Adorno, as relações sociais de produção, anacrônicas em relação às forças produtivas, se autonomizaram, e a expectativa de se construir uma nova sociedade a partir do desenvolvimento das forças produtivas já é uma aparência socialmente necessária e instrumentalizada para a manutenção do sistema.

Assim, o desejo de reproduzir a divisão técnica do trabalho vivenciado no sistema capitalista, as quais o Movimento entende que poderão levar o indivíduo a um novo patamar de consciência, bem como são essenciais para garantir a fixação do homem no campo e demonstrar o "sucesso" da reforma agrária, pode proporcionar um aumento da reificação e da heteronomia, ao submeter os indivíduos á lógica da racionalidade instrumental do mundo administrado.

O fato de a produção colocar-se como central, em detrimento da própria subjetividade dos indivíduos, contribui para que a produção assuma a posição de "finalidade em si", o que bloqueia "o objetivo que seria a realização plena da liberdade" (ADORNO, 1986c, p. 72). Dessa forma, a crítica não é à importância dada à produção, mas a um produtivismo que pode desembocar na não liberdade do indivíduo, na reprodução da reificação entre aqueles que querem superá-la. 
Cabe pontuar que Adorno vai criticar o produtivismo apresentado por grupos de esquerda, entendido como uma assunção da racionalidade instrumental do sistema capitalista. Em uma sociedade emancipada, o homem seria visto como o fim em si mesmo por excelência, e o produtivismo seria superado, e o homem poderia simplesmente "ser, e mais nada" (ADORNO, 1992, p. 138).

O próprio MST, em alguns momentos nos textos, reconhece sua tendência a dar ênfase aos aspectos econômicos e produtivos, negligenciando os aspectos sociais e as outras esferas da vida humana. É importante lembrar que face à abrangência social da lógica da mercadoria, as possibilidades de contestação neste mundo totalmente administrado eventualmente tenham se retirado para a esfera individual:

[...] a forma como organizamos os assentamentos acentua a visão econômico corporativo. [...] teremos de contemplar em nossas ações propostas para as diversas esferas da vida humana e não apenas para as necessidades econômicas. (CONCRAB, 2004, p. 40).

Quanto aos aspectos políticos do assentamento, o objetivo é levar o assentado a evoluir da consciência social que adquiriu na luta pela terra para a consciência de classe:

Portanto, preparar o nosso povo para o enfrentamento de classe é uma tarefa revolucionária. Educá-lo para combater e produzir é uma responsabilidade histórica que não podemos nos eximir, sob pena das futuras gerações nos cobrarem pela falta de ousadia dos homens/mulheres 
de hoje, que não souberam trabalhar com o tempo e o povo (ANCA, 2002, p. 24).

Há uma preocupação por parte do MST de que o assentado assuma posicionamentos e faça as opções que estejam de acordo com a concepção política do Movimento, percebendo-se uma certa tendência à padronização e organização, mesmo no que diz respeito às questões de sociabilidade e organização da vida dentro do assentamento, abarcando desde questões de arranjo espacial do assentamento, quanto questões estéticas, passando por costumes e incluindo o conteúdo das opções religiosas:

o crédito deverá fortalecer a estratégia econômica previamente estabelecida no plano de produção e reforçar as formas de cooperação adotadas. [...] Não podemos abrir mão do controle político do crédito, pois ele é o alicerce que dará sustentação a esse plano (ANCA, 2002, p. $16)$.

As casas, quando possível, deverão ser construídas no mesmo alinhamento. Buscar um consenso entre todas as famílias para elas pintarem as casas numa mesma cor, mesmo aquelas que ainda não foram rebocadas. As estruturas internas do quintal (por exemplo o galinheiro) deverão ter um certo padrão e estar bem localizadas (ANCA, 2002, p. 22).

As discussões junto à base são compreendidas, assim, como um espaço de convencimento dos assentados, e a liderança deve respeitar a velocidade deles 
“internalizarem” a proposta que está dada de antemão pelo MST. Há uma certa dificuldade em lidar com a divergência, que deve ser eliminada, e as discordâncias com relação à proposta são de antemão significadas como uma discordância dos princípios políticos do MST:

Evidentemente que [...] haverão famílias que discordarão da proposta. Estas famílias se apegarão em detalhes da proposta para desqualificá-la. No fundo, elas discordam dos princípios que norteiam o conteúdo político da nova forma de organização do assentamento. Nestes casos, não haverá outro remédio. Teremos de tomar internamente a decisão de transferi-la para outro local, seja outro acampamento ou outro assentamento. (ANCA, 2002, p. 26).

Cabe pontuar que a possibilidade de transferir para outro acampamento ou assentamento aquele que discordar da proposta colocada, tende a inibir as vozes dissonantes, sancionando um pensamento único, e acabando com os espaços de discussão e formação, posto que induz as pessoas a não se colocarem realmente, mas verbalizarem somente aquilo que elas acreditam que é o esperado delas.

Além disso, essa postura deixa entrever uma compreensão de que onde se deve chegar já está dado de antemão, deve-se apenas respeitar a velocidade do assentado/acampado de chegar a ter essas opiniões, ou esses pensamentos.

À semelhança do pontuado por Caume (2002), podemos notar que boa parte dos verbos se encontra na conjugação imperativa, colocando as orientações de forma 
normativa. Há uma preocupação com a coesão social, com a normatização das regras de convivência, e com um certo controle da vida social:

as bodegas são a semeadura dos vícios e das desgraças dentro dos assentamentos. (...) todo mercadinho e toda bodega deve ser comunitário, administrado pela coordenação do futuro assentamento ou pelos núcleos de base (ANCA, 2002, p. 19).

Pode-se perceber uma tendência ao ordenamento de vários aspectos do assentamento, presente nos textos estudados, que se dirigem a todos os fenômenos sociais, partindo da produção e incluindo o lazer e o ócio, apontando para uma administração completa da vida. Nesse sentido, há uma reprodução dos mesmos mecanismos da sociedade administrada, segundo os quais a sociedade está inteiramente planejada e organizada, e pretende impor sua organização a todas as formas de expressão.

Considerando que justamente "o gesto de insistir na independência e na autonomia, na separação do vigente reino das finalidades, implica, ao menos de modo inconsciente, a referência a um estado em que a liberdade estaria realizada" (ADORNO, 1986d, p. 80), a normatização e a tendência a uniformizar e a homogeneizar atentam contra o desenvolvimento da capacidade crítica e de autonomia do indivíduo.

Esses aspectos de ordenamento da vida, somados ao produtivismo, indicam uma presença da racionalidade instrumental na lógica de organização do movimento social. Considerando que a racionalidade instrumental, típica desta sociedade administrada, entende o fim como já dado, e que as ações são planejadas e ponderadas a partir de seu fim, a racionalidade instrumental caracteriza-se por ser pragmática, pela submissão de seu 
conteúdo à heteronomia, visto que o que importa nela é seu valor operacional, sua utilidade para controlar o mundo (ADORNO, 1992; LEOPOLDO E SILVA, 1997).

Considerando que a racionalidade instrumental é afim do domínio racional sobre a natureza, o qual tem como desdobramento um domínio irracional sobre o homem, a lógica que ora se pretende aplicar na organização do assentamento pode desembocar em um autoritarismo e na reprodução das relações de dominação, que como o próprio Movimento pontua, está presente na forma de direção das lideranças rurais. Lembramos que o autoritarismo não é 'privilégio' das lideranças rurais, estando presente em toda a sociedade, sendo fruto do caminho pragmático e matematizado trilhado pelo processo de esclarecimento.

Lembramos que o autoritarismo reforça a heteronomia, pois o indivíduo com tendências autoritárias apresenta um superego externalizado, isto é, delega para terceiros o papel de decidir para ele como agir, o que é correto ou errado. Assim, uma postura que não consegue romper com a lógica do mundo administrado, reproduzindo-a em suas formas de centralização, dominação e controle, desincentiva o pensamento e solapa as possibilidades de autonomia e emancipação dos indivíduos.

Esse tipo de atuação vai inclusive contra outras posições colocadas pelo próprio MST, em especial aquelas assumidas por este na questão da educação, na qual é influenciado pelas teorias de Paulo Freire, que postula que o indivíduo chega à consciência e ao aprendizado através da reflexão crítica sobre sua vida e seu meio, em um processo onde as pessoas se educam de forma dialógica, na relação com o outro.

Nesse aspecto, há elementos de contradição entre uma postura que valoriza a autonomia dos indivíduos, representada por um desejo manifesto de substituir "os poderes existentes no campo por novos poderes (populares) [que] constitui a essência da reforma 
agrária" (CONCRAB, 2004, p. 12); e uma postura que delega aos dirigentes a tarefa de pensar e de "educar" o assentado, levando-o a alcançar uma idéia já pré-formada.

Além disso, é bem marcada a divisão entre os dirigentes e a base. Os documentos estudados se dirigem à liderança, contendo, no caso da cartilha "O que levar em conta ...", orientações sobre como conduzir a discussão no acampamento, para garantir que os princípios do MST sejam aplicados na organização do assentamento; e no caso dos outros dois documentos, defendendo o projeto da Comuna da Terra, seja internamente ("Idéias para um novo modelo de reforma agrária: Comuna da Terra”), seja para o público em geral ("Novas formas de assentamento da reforma agrária: a experiência da Comuna da Terra").

Assim, percebe-se um reconhecimento das assimetrias das relações, dos papéis e dos conhecimentos envolvidos na discussão e na condução do processo de organização do assentamento, mas não uma reflexão no sentido de superá-las.

Cabe retomar aqui o que Rouanet (1985) coloca como condições para a democracia e para um verdadeiro diálogo político, quais sejam, a liberdade do processo argumentativo, a ausência de violência, a liberdade plena de propor e contestar normas e a consciência verídica não deformada pelos mecanismos de defesa, que não são possíveis em grupos que lidam com os indivíduos como se eles não tivessem capacidade de se auto-governar, e que precisam de uma elite pensante para isso. $\mathrm{O}$ autor pontua que a ideologia assumida por alguns grupos de esquerda - que assumem essa posição de incapacidade e menoridade do indivíduo - inviabilizaria a construção de verdadeiros espaços de discussão política e pública, contribuindo para reificar o indivíduo e para o não desenvolvimento de sua consciência.

Se os textos de orientação à ação dos militantes já partem de uma concepção do sujeito que diminuem a margem de divergência, de autodeterminação e de aprendizagem 
através de sua própria experiência, ainda que seja por tentativa e erro, cabe perguntar se essa postura não induz as lideranças a, na prática, assumir uma postura mais autoritária e de desconsideração com o saber e os desejos da base, criando com isso desentendimentos e embates, ocasionando assim o que Adorno pontuou como um gasto de energia inútil, pois os esforços que poderiam ser direcionados ao avanço da luta são despendidos em mecanismos para se lidar com a liderança, como racionalizações, pequenas sabotagens, ou enfrentamento direto entre liderança e base.

Por outro lado, é importante frisar as compreensões apresentadas não são isentas de tensões e questionamentos dentro dos próprios textos estudados, como se pode perceber pelas preocupações como a de evitar a reprodução da dominação típica das lideranças rurais/campesinas.

Os textos que tratam da educação dentro do MST também evidenciam essa preocupação, ao questionarem a relação autoritária e de "transferência" de conhecimento, onde um é considerado o que sabe, e o outro deve ser um receptor passivo desse conhecimento.

Além disso, há que se considerar que o MST e sua direção/liderança não são um todo monolítico, havendo uma disputa de concepções, correntes e projetos dentro do Movimento. No Estado de São Paulo, há a tentativa por parte da liderança estadual em implementar a Comuna da Terra, que é um projeto de teóricos ligados ao MST estadual. Outras lideranças ligadas a outras regionais ou estaduais possuem outros projetos.

Abaixo, segue uma tabela com os temas e as ênfases presentes nos textos estudados, bem como a frequência com que esses temas aparecem: 
Tabela 1: Temas presentes nos textos estudados.

\begin{tabular}{|c|c|c|c|c|}
\hline Tema & Freq & \multicolumn{2}{|l|}{ Enfoque } & Conteúdo \\
\hline Produção agrícola & 56 & \multicolumn{2}{|c|}{-} & $\begin{array}{l}\text { Tendência ao individualismo do camponês; planejar e } \\
\text { organizar; coletivo; renda mínima; agroindústria e } \\
\text { industrialização; crédito; atividades não agrícolas; } \\
\text { Plano de Produção; cooperação agrícola; organizar um } \\
\text { novo modelo de produção; questões tecnológicas e } \\
\text { ambientais; garantir a produção e não a propriedade da } \\
\text { terra. }\end{array}$ \\
\hline \multirow[t]{3}{*}{ Coletivo } & \multirow[t]{3}{*}{22} & $\begin{array}{l}\text { Produç } \\
\text { ão }\end{array}$ & 12 & \multirow[t]{3}{*}{$\begin{array}{l}\text { Vida e trabalho; avanço rumo à coletivização plena; } \\
\text { educação para a coletividade; memória coletiva. }\end{array}$} \\
\hline & & Social & 6 & \\
\hline & & Ambos & 4 & \\
\hline \multirow[t]{3}{*}{ Cooperação } & \multirow[t]{3}{*}{20} & $\begin{array}{l}\text { Produç } \\
\text { ão }\end{array}$ & 14 & \multirow{3}{*}{$\begin{array}{l}\text { Agrícola; crédito, trabalho, socialização dos meios de } \\
\text { produção; entre as famílias; nos outros campos da } \\
\text { necessidade humana }\end{array}$} \\
\hline & & Social & 3 & \\
\hline & & Ambos & 3 & \\
\hline Consciência & 19 & & & $\begin{array}{l}\text { Produto do convívio social e participação; necessidade } \\
\text { de construir novos hábitos e valores; modificar a } \\
\text { consciência do camponês; recuo na consciência depois } \\
\text { que é assentado; necessidade de estruturas no } \\
\text { assentamento que facilitem o desenvolvimento da } \\
\text { consciência; transformar a consciência social em } \\
\text { consciência de classe. }\end{array}$ \\
\hline \multirow[t]{3}{*}{ Organização } & \multirow[t]{3}{*}{18} & $\begin{array}{l}\text { Produç } \\
\text { ão }\end{array}$ & 3 & \multirow{3}{*}{$\begin{array}{l}\text { Da produção, do assentamento; dos grupos de base; da } \\
\text { participação; do tempo; das famílias segundo o Plano } \\
\text { de Produção e os princípios organizativos; do } \\
\text { assentamento em grupos de famílias amigas; da escola; } \\
\text { para acumular forças no atual estágio da luta de } \\
\text { classes. }\end{array}$} \\
\hline & & Social & 7 & \\
\hline & & Ambos & 8 & \\
\hline $\begin{array}{l}\text { Sociabilidade das } \\
\text { famílias }\end{array}$ & 17 & \multicolumn{2}{|c|}{ - } & $\begin{array}{l}\text { Relações interpessoais, moradia próxima; organização } \\
\text { da infraestrurura; lazer; cultura, solidariedade; relações } \\
\text { familiares. }\end{array}$ \\
\hline $\begin{array}{lll}\text { Relação } & \text { com } & 0 \\
\text { Estado } & & \end{array}$ & 15 & \multicolumn{2}{|c|}{ - } & $\begin{array}{l}\text { Assistência técnica; políticas públicas; garantir que a } \\
\text { atuação do executivo fortaleça os princípios do MST; } \\
\text { trabalho conjunto; luta; pressão; negociação; } \\
\text { legalização do assentamento. }\end{array}$ \\
\hline Luta de classes & 15 & \multicolumn{2}{|c|}{-} & $\begin{array}{l}\text { Revolução Cultural; socialismo; acúmulo de forças; } \\
\text { enfrentamento ideológico, alienação; massificaçãa da } \\
\text { luta; avanço do capitalismo no campo; participação em } \\
\text { outras lutas populares. }\end{array}$ \\
\hline $\begin{array}{l}\text { Relação com } \quad 0 \\
\text { urbano }\end{array}$ & 15 & \multicolumn{2}{|c|}{ - } & $\begin{array}{l}\text { Rururbano; comércio direto; recampesinação; apoio da } \\
\text { população urbana; cultura urbana; problemas urbanos. }\end{array}$ \\
\hline $\begin{array}{l}\text { Meio ambiente, } \\
\text { agroecologia }\end{array}$ & 14 & \multicolumn{2}{|c|}{-} & 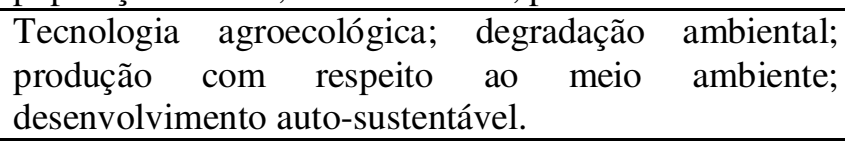 \\
\hline \multirow[t]{2}{*}{ Discussões } & \multirow[t]{2}{*}{12} & $\begin{array}{l}\text { Produç } \\
\text { ão }\end{array}$ & 2 & \multirow{2}{*}{$\begin{array}{l}\text { Orientar as discussões nos núcleos; sem pressa; com } \\
\text { convicção dos princípios; organizar e normatizar o } \\
\text { funcionamento do assentamento; garantir o controle }\end{array}$} \\
\hline & & Social & 3 & \\
\hline
\end{tabular}




\begin{tabular}{|c|c|c|c|c|}
\hline & & Ambos & 7 & $\begin{array}{l}\text { político sobre o corte do assentamento e sobre o } \\
\text { processo de produção; estimular a criatividade dos } \\
\text { assentados resguardando os princípios do MST. }\end{array}$ \\
\hline $\begin{array}{l}\text { Participação } \\
\text { convivência }\end{array}$ & 10 & & - & $\begin{array}{l}\text { Aumento da consciência, qualificada; regras de } \\
\text { convivência para evitar problemas; dos militantes e } \\
\text { lideranças com os núcleos de base; organização da área } \\
\text { social que facilite a participação e convivência; lúdico, } \\
\text { lazer, cultura. }\end{array}$ \\
\hline $\begin{array}{l}\text { Desconcentração } \\
\text { fundiária }\end{array}$ & 6 & 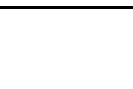 & - & Cumprimento da função social da terra \\
\hline Comercialização & 6 & ( & - & Direta com a cidade; criar a marca da reforma agrária \\
\hline Organicidade & 6 & & - & $\begin{array}{l}\text { Estimular a participação de todos nas reuniões; } \\
\text { processo decisório coletivo; coletivos nos } \\
\text { acampamentos e assentamentos; escola voltada à } \\
\text { organicidade. }\end{array}$ \\
\hline Subjetividade & 5 & & - & $\begin{array}{l}\text { Emoções, memória, subjetivismo do camponês, } \\
\text { identificação entre os assentados; desejo, sonho e } \\
\text { felicidade das famílias; relações interpessoais, } \\
\text { amizade. }\end{array}$ \\
\hline Democracia & 3 & & - & Na sociedade brasileira; nas relações interpessoais. \\
\hline Igualdade & 3 & & - & De gênero, de direitos. \\
\hline Solidariedade & 3 & & - & $\begin{array}{l}\text { Na relação interpessoal, na produção, com outras lutas } \\
\text { populares. }\end{array}$ \\
\hline Grupos religiosos & 3 & & - & $\begin{array}{l}\text { Apoio à luta; 'amigos'; libertadores ou alienantes - } \\
\text { necessidade de controle. }\end{array}$ \\
\hline
\end{tabular}

Fontes: Cartilha "Novas formas de assentamentos da reforma agrária: a experiência da Comuna da Terra", produzida pela CONCRAB, apostila "O que levar em conta para a organização do assentamento, produzido pela ANCA, e o texto "Idéias para um novo modelo de reforma agrária 'Comuna da Terra'”, produzido pelo MST.

Como se pode perceber, a ênfase presente nos textos estudados são as questões de produção, seguidas pelas questões políticas, em especial a formação da consciência política dos assentados. Esse destaque dado à produção decorre da visão marxista de que o trabalho é o eixo que dá significado e o sentido para a vida do homem, e de que é no trabalho onde ocorre à exploração dos indivíduos pelo sistema capitalista (CONCRAB, 2004).

Para o MST, o homem somente alcançará a emancipação se tiver clareza de sua condição de classe, e lutar contra e exploração e a dominação capitalista, e conseguir encontrar a "justiça social, a igualdade de direitos em todos os aspectos: econômico, 
político, social, cultural e espiritual”, enfim, quando uma nova humanidade se constitua de forma comunitária e coletiva.

Após estudarmos as concepções que balizam a ação do MST na organização de um assentamento, cabe perguntar como essas orientações são colocadas em prática, em um caso concreto de organização de um assentamento. 


\section{O Sepé Tiaraju e o MST}

Os homens fazem sua própria história, mas não a fazem como querem; não a fazem sob circunstâncias de sua escolha e sim sob aquelas com que se defronta diretamente, legadas e transmitidas pelo passado. A tradição de todas as gerações mortas oprime como um pesadelo o cérebro dos vivos.

Karl Marx

O assentamento em tela foi escolhido para o desenvolvimento do trabalho de campo em função de sua importância. A Comuna da Terra/Projeto de Desenvolvimento Sustentável Sepé Tiaraju é considerado um assentamento-modelo tanto pelo MST quanto pelo governo federal (INCRA), sendo o primeiro nesses moldes adotado no Estado de São Paulo.

A região onde está localizado o assentamento se caracteriza pela monocultura extensiva de cana, para beneficiamento nas várias usinas da região, com o fim de produzir álcool. Segundo dados do IBGE, reportados pela CONCRAB (2004), noventa e oito por cento da área agrícola da região de Ribeirão Preto é destinada ao plantio de cana-de-açúcar.

Já segundo os indicadores do Índice Paulista de Responsabilidade Social - IPRS (SEADE, 2002), a produção de cana-de-açúcar para o setor sucroalcooleiro corresponde a $73 \%$ do valor total da produção agrícola da região. Outros produtos, como carne bovina, frango e ovos aparecem em segundo lugar, correspondendo cada um a cerca de $3 \%$ do valor 
total da produção. O poder econômico se traduz em poder político, e os usineiros têm uma influência bastante grande na região, que é conhecida como capital brasileira do agronegócio, recebendo também a alcunha de "Califórnia brasileira".

Se é grande o volume de riqueza em circulação, também é grande a concentração dessa riqueza, que acaba por caminhar junto com a pobreza de muitos. A região se constitui em um pólo de atração de migrantes, atraindo um grande número de trabalhadores pouco qualificados, além de trabalhadores volantes, conhecidos como 'bóias-frias', para o trabalho sazonal na cana. Esses trabalhadores, que em geral residem nas pequenas cidades do entorno de Ribeirão Preto, ou nos bairros periféricos da cidade, ficam desempregados nos períodos de entressafras, vivendo muitas vezes em condições de miserabilidade.

O próprio trabalho de corte de cana, realizado por esses trabalhadores, também é degradante. Há casos recorrentes de morte por exaustão, sendo que no período de 2004 a 2007, foram 19 os casos de morte reportados no Estado de São Paulo, e estudos sociológicos têm demonstrando que a vida útil de um trabalhador bóia-fria é menor do que a de um escravo, tendo-se em vista que um trabalhador escravo 'durava' entre quinze e vinte anos trabalhando, enquanto o bóia-fria consegue trabalhar somente 12 anos nesse tipo de atividade, ficando incapacitado para o trabalho após esse período (FOLHA DE SÃO PAULO, 29 de abril de 2007). Segundo a professora Maria Aparecida Moraes Silva, que realiza pesquisas na área, o trabalho no corte de cana se trata de um trabalho escravo travestido/com aparência de trabalho livre, em função de ter carteira assinada (MST, 2008).

Assim, o assentamento Sepé Tiaraju assume, dentro do MST e da causa pela reforma agrária, um valor simbólico e estratégico muito grande. É o primeiro assentamento da região de Ribeirão Preto. Marca um movimento claramente contrário ao percebido na região, que é o de diminuição da agricultura familiar e aumento da concentração fundiária e 
da monocultura canavieira, bem como apresenta uma proposta alternativa e palpável àquela apresentada pelos usineiros como sendo a única saída para os trabalhadores rurais, que é a expansão do agronegócio e da cana como forma de aumentar a quantidade de postos de emprego de bóias-frias disponível.

O sucesso do acampamento Sepé Tiaraju, de certa forma, fez com que ele se multiplicasse, dando frutos para o trabalho do MST regional. Hoje já existem outros acampamentos promovidos pelo MST na região, e um segundo assentamento, este no município de Ribeirão Preto, decorrente de um acampamento com quase 500 famílias, está para ser homologado. Segundo o Sr. Arthur, assentado no Sepé Tiaraju:

\footnotetext{
"Hoje, a consciência desse povo, que voltaro (para a cidade), que voltaro muito embora, a pressão do governo, que naquela época o governo que tava era o Fernando Henrique, a pressão dele fazendo polícia batê, fazia com que muitas pessoas se recusou, preferiu voltar pra miséria, pro sofrimento, não acreditou tanto... Hoje, parte dos assentados que tem hoje são pessoas que recusou e depois voltou e acreditou, e hoje graças a Deus estamos assentados.” (Sr. Arthur, entrevista).
} 


\subsection{O período do acampamento}

Segundo Scopinho, Oliveira, Resende e Santos (2007), o MST chegou à região de Ribeirão Preto no ano de 1999, assumindo a organização de um assentamento cuja ocupação inicialmente havia sido promovida por um sindicato que não tinha ligações com a reforma agrária.

O primeiro acampamento organizado pelo MST na região foi o que originou o assentamento Sepé Tiaraju, com a ocupação da Fazenda Santa Clara no dia 17 de abril de 2000 (SCOPINHO et al., 2007; CONCRAB, 2004). O acampamento foi formado por famílias oriundas de vários acampamentos de outras regiões do estado (SCOPINHO et al., 2007).

Essa fazenda havia sido perdida por uma usina de cana para o governo do Estado de São Paulo em 1992, em virtude de uma dívida. O controle da fazenda não tinha passado efetivamente para o poder público, pois o usineiro continuava plantando cana e arrendando a área. Com a ocupação da área pelo MST, o governo estadual destinou a área para leilão, prometendo assentar os acampados em outra região (CONCRAB, 2004).

Com o apoio de parte da sociedade civil, o MST exerceu uma forte pressão sobre os possíveis compradores nos leilões programados pelo Governo Estadual, o que fez com que nenhum interessado aparecesse. Assim, após quatro anos de luta, de ocupações, despejos e reocupações, a terra foi adquirida do governo estadual pelo Instituto Nacional de Colonização e Reforma Agrária (INCRA) ${ }^{3}$, que a destinou para assentamento. A história do

\footnotetext{
${ }^{3}$ O INCRA é o órgão do governo federal responsável pela realização da Reforma Agrária (vistoria das fazendas com suspeita de improdutividade, aplicação dos índices de produtividade e desapropriação das terras por interesse público ou social), pela efetiva instalação dos assentamentos (realização de obras de infraestrutura, seleção das famílias a serem assentadas, programas emergenciais, liberação de crédito, entre
} 
leilão aparece com bastante força no discurso dos "militantes", que contam sobre a descrença de que aquela terra saísse, em virtude do histórico de ocupações, da força política dos usineiros na região, bem como da postura do governo estadual.

Os assentados, quando vão narrar a luta pela terra, pontuam as dificuldades da luta, de estarem acampados em uma terra de usina, os despejos e reocupações, o medo de colocarem fogo nas barracas enquanto eles estivessem dormindo, o frio, a chuva, o montar e desmontar das barracas. Segundo Dona Ana, assentada ligada à liderança regional do MST, "agora que vão construir a casa dela, vai ser a $32^{\mathrm{a}}$ moradia que ela construiu entre acampamento e assentamento" (Diário de Campo, p. 32; 20/10/06).

Já Geraldo, outro assentado militante, "teve muito medo de colocarem fogo no barraco, de um carro desgovernar e acertar eles lá, mas que era muito bom (...)" (Diário de Campo, p. 98, 30/01/07). Havia também medo de apanhar da polícia ou de ser agredido por pessoas da cidade enquanto se estava dormindo:

\begin{abstract}
"Eu ficava com medo: e se a polícia vier aqui de noite e metê bala ni nóis?... esses barraco véio de lona, o cara passa aí na pista e dá um tiro aqui... vich!, eu tinha um medo danado, aquele movimento de carro...” (Sr. Geraldo, entrevista).
\end{abstract}

"Aí os fazendeiro, os usineiro entrava com os advogados deles ameaçando a lei, apoiando deputado, apoiando senador, onde é que a

outros), bem como pelo acompanhamento e pela garantia de assistência técnica às famílias assentadas. Além disso, é de responsabilidade do INCRA a manutenção de um cadastro acerca da situação de todas as terras do país, o que faz com que os fazendeiros também sejam um dos públicos atendidos por esse órgão federal.

4 "Militantes" é o termo majoritariamente usado pelos assentados para se referirem àqueles que têm algum cargo de direção no MST, ou alguma proximidade com a liderança, ainda que eventualmente usem esse termo para se referirem a si mesmos. 
polícia nos tirava debaixo de couro. Eu já apanhei, já apanhei várias vezes da polícia nessa luta que nóis tá.” (Sr. Arthur, entrevista).

Vários assentados verbalizam que a pior dificuldade encontrada foi a fome, pois dependiam da doação de alimentos, e nem sempre essas chegavam de forma suficiente. $\mathrm{Na}$ fala dos assentados, aparece inclusive o risco de inanição, em função de longos períodos que ficavam sem comer:

\footnotetext{
"O mais difícil na época do acampamento, foi a questão da alimentação. Por mais apoio que a gente tinha, mas sempre faltava. Eu mesmo fui coordenador de arrecadação, que andava de porta em porta na cidade, fazendo arrecadação de alimentação. As veiz se arrecadava, mas arrecadava muito pouco, chegou um momento que a gente tinha só fubá, fazê sopa de fubá pra se alimentar as famílias, tinha que fazê na cozinha coletiva pra se dividir pra todo mundo, então foi uma dificuldade muito grande." (Sr. Angelo, entrevista).
}

Alguns assentados contavam que algumas vezes eles tinham que ficar o dia inteiro "se sustentando" com uma colherinha de café.

Outra dificuldade muito grande foi a falta de água, seja para beber, seja para cuidar da higiene pessoal. Na fala dos assentados, aparece a história de um senhor que, na época do acampamento, morava na casa que posteriormente serviu de secretaria para o Movimento, que negava água da mina para eles beberem. Eles acabavam tendo que usar água suja do rio: 
"Outra dificuldade muito grande, a questão da água, por devido a gente não ter apoio do município, então cê tinha que pegar água até suja no rio, que cê não sabia que ela... que ela era água 'esgotada', mas tinha que usar... então isso foi muito difícil pra nóis. A gente tentava abrir poço, mas aqui mesmo não deu... [...] até quando o município trazia água pra nóis, era água de rio, trazida de caminhão... era distribuída 50 litros para cada família, então era muito difícil.” (Sr. Angelo, entrevista).

Também é recorrente a história do sítio do "seu Luiz Português". Durante os despejos, o Sr. "Luiz Português" cedeu a área de pequeno sítio, localizado no meio da Fazenda Santa Clara, para os acampados armarem suas barracas e viverem ali. Por duas ocasiões, o Sr. "Luiz Português" cedeu a área para eles acamparem (Diário de Campo, p. 98; SCOPINHO et al., 2007). Após muita pressão dos usineiros, o Sr. Luiz acabou vendendo o sítio e indo para a cidade. Os acampados foram despejados, e se mudaram para a "linha do trem", terra pública que ladeava os trilhos do trem e a antiga estação ferroviária, dentro da Fazenda (Diário de Campo, p. 98; SCOPINHO et al., 2007).

Ficaram acampados na linha do trem até dezembro de 2002, quando então reocuparam a Fazenda Santa Clara, onde foram assentados (SCOPINHO et al., 2007). A fazenda foi reocupada em virtude da informação que correu entre os acampados de que um grupo de sem-tetos da cidade iria ocupar também uma parte da Fazenda, onde hoje é o núcleo Chico Mendes (Diário de Campo, p. 95).

Durante o período de acampamento, foram constantes as mudanças, as ocupações, reintegrações de posse e reocupações, bem como as aglutinações de acampamentos 
diferentes. Quando o INCRA foi "emitido na posse", havia cerca de quarenta famílias acampadas na Fazenda Santa Clara. Para completar o número de oitenta, que seriam assentadas naquele espaço, foi necessária a transferência de mais ou menos quarenta famílias de outros três acampamentos do MST: do acampamento "Terra Sem Males" de Campinas, do acampamento "Dom Hélder" de Barretos, e do acampamento "Mário Lago" de Ribeirão Preto.

Das famílias que originaram a primeira formação do acampamento, somente quatro foram assentadas, sendo que muitas desistiram ou mudaram de acampamento ao longo do tempo, sendo substituídas por outras que ingressaram "na luta" durante a série de ocupações e reocupações. Os assentados contam que um dos acampamentos que foram aglutinados ao Sepé Tiaraju, o acampamento da usina Ximbó, começou com 1200 famílias. Quando foi reintegrada a posse para a usina, e eles tiveram que ocupar outro local, o número de famílias caiu para 600. No final, quando este acampamento estava na cidade de Barretos e foi absorvido pelo Sepé, haviam restado somente 8 famílias.

Alguns assentados no Sepé Tiaraju ficaram por cerca de oito anos "debaixo da lona", ou seja, acampados nas barracas de lona preta. Outros, que foram transferidos de acampamentos mais recentes para completar o número de famílias que seriam assentadas no Sepé, ficaram acampados por cerca de seis meses.

Comparando a ocupação que deu origem ao Sepé Tiaraju com outras ocupações anteriores, pode-se perceber que houve uma mudança nos métodos de ação do MST ao longo dos anos, incluindo aí a forma de recrutar as pessoas para participar das ocupações. No presente caso, muitos assentados referem terem sido convidados por meio de auto-

\footnotetext{
${ }^{5}$ Quando o INCRA é emitido na posse, significa que o órgão possui aquela terra para destinar para a reforma agrária.
} 
falantes, não acontecendo reuniões prévias de preparação. Dona Cíntia, hoje assentada, conta que entrou para o MST "quando o carro de som passou em Serrana dizendo que quem queria terra tinha que fazer a inscrição no domingo na praça, que a ocupação seria no dia seguinte" (Diário de Campo, p. 91; 29/01/2007).

“[E como é o trabalho de base do MST?] Usa assim... eles pegam alguns militantes, e eles saem casa por casa na cidade, sai anunciando nuns carros assim... com auto-falantes e ... dizendo que 'quem quer um pedaço de chão, vem, junte-se a nós do MST, o MST vai fazer assim... uma ocupação na fazenda tal', e assim por diante e... [e eles falam isso no auto-falante?]. Auto-falante. [E aí eles falam onde que eles podem ser encontrados?] Não, eles tiram um local assim... dentro da cidade. Ali, faz o cadastro das pessoas, faz o cadastro, só que na verdade a gente vem como... sem saber aonde que é o local, aí quando você chega que você descobre onde que é o local, você vem mesmo quase que no escuro." (Ivan, entrevista).

Segundo alguns militantes entrevistados, o trabalho de base do MST sofreu algumas alterações com o tempo. Conforme nos conta uma das lideranças mais antigas, na sua cidade, o MST fazia reuniões preparatórias com as pessoas interessadas em ocupar terra. Segundo essa liderança, nessas reuniões

"[nas reuniões de preparação] era falado pra que as pessoas, ele crie coragem, pra ir buscar o seu recurso, pra que ele... pra ele ser ele mesmo seu próprio patrão, ele mesmo não precisar ter patrão mandando, ter 
encarregado, então... E que tem terras, muitas, devolutas, ou as vezes a terra não tá devoluta, as vezes, como eles dizem, ela tá produzindo, mas na verdade mesmo ela não tá cumprindo com sua função social, porque para... o que é muito falado, é que é pra terra cumprir com a função social dela, porque as vezes o trabalhador tá lá, tá explorado, e as vezes não tá com o equipamento adequado para o trabalho, ele não tem um ganho suficiente do trabalho dele, e as vezes trabalhando numa terra que já tá com dívida com o Estado, a pessoa, mesmo a terra sendo dele, ela ainda tá sendo explorado." (Sr. Angelo, entrevista).

Conforme pontuam alguns teóricos, anteriormente, nos primórdios do MST, a ocupação só era realizada após a pessoa ter participado de várias reuniões preparatórias, nas quais se discutia o direito à terra, a ocupação, a reforma agrária, a exclusão social, elementos da história do país, entre outros. As pessoas iam para a ocupação com alguma carga de reflexão já feita, inclusive sobre as dificuldades que iriam encontrar no período de acampamento.

Essas reuniões eram organizadas em geral nos espaços cedidos por igrejas, com uma presença e contribuição muito forte das CEBs - Comunidades Eclesiais de Base, e tinham como função ser um momento de discussão teórica e conceitual, usando para isso uma linguagem religiosa, partindo dos conceitos e do referencial teórico e reflexivo que os indivíduos já tinham, sendo estes, em geral, os de origem religiosa (VASQUEZ, 2002), preparando as famílias que iriam participar das ocupações, e que iam para o assentamento conscientes de sua opção e dos possíveis enfrentamentos que ela poderia acarretar. 
Segundo vários teóricos, o MST, em função de mudanças internas, optou por um afastamento da igreja, em especial da católica, que tinha mais influência no Movimento; mas a própria igreja também se afastou do MST, em virtude de transformações internas pelas quais passou (MARTINS, 2000). Esse afastamento, que diminuiu a influência da igreja no movimento social, também fez com que o trabalho de reflexão se alterasse, havendo uma mudança na metodologia de preparação política daqueles que compõem a base do Movimento (GOHN, 2000; MARTINS, 2000; ROS, 2005).

Outro fator que concorre para a alteração na metodologia de atuação é o crescimento do número de assentamento, de famílias acampadas e de ocupações, com o consequente aumento na carga de trabalho realizado pela liderança do MST.

Assim, à medida que o MST foi mudando suas concepções e formas de atuação, de acordo com as publicações estudadas, o momento do acampamento passou a ser considerado como o espaço privilegiado para a aprendizagem e para a formação da consciência dos indivíduos.

Os assentados são chamados a participar da ocupação sem um trabalho de reflexão prévia, conforme visto no presente caso, onde parte dos assentados refere ter sido chamada com carro de som. Diminuiu-se assim o espaço de exercício intelectual e de reflexão teórica antes da entrada na terra, que era proporcionado pela participação nas reuniões de discussão, na época que o MST era ligado à igreja progressista.

Navarro (2002) fala da mudança ocorrida no MST com a alteração no perfil dos líderes, em função da troca da primeira pela segunda geração de lideranças. Os da primeira geração eram oriundos (ou tinham uma forte ligação) de entidades religiosas, tendo tido uma forte influência dos princípios, dos símbolos e da metodologia religiosa, que incentivam a introversão e a reflexão, como base para a ação. Já a segunda geração tem 
uma origem na própria luta pela reforma agrária, parte de outro referencial teórico e de prática, que valoriza muito mais a intervenção prática na realidade, com o momento reflexivo associado a esta.

O trabalho reflexivo, segundo Adorno (1992), quase já não é mais possível em nossa sociedade. Deixá-lo para o momento do acampamento acentua os elementos práticos, ou a reflexão ligada à ação, o que em si não é negativo, mas coloca em segundo plano o pensamento enquanto exercício em si. Como, para que o pensamento possa refletir sobre si mesmo, exige-se o exercício da interioridade, e não somente a crítica prática, podemos assim imaginar que a diminuição do período de reflexão prévio enfraquece alguns aspectos do processo formativo dos indivíduos e, num certo sentido, diminui o alcance do movimento social em multiplicar os espaços de reflexão crítica, pois não são todos os que vão para a ocupação que conseguem ficar no acampamento em virtude das duras condições do mesmo.

Além disso, há que se considerar que a dureza das condições do acampamento induz a que as famílias também adotem estratégias alternativas de resistência e acomodação em sua inserção na luta: a não sensibilização prévia das famílias como um todo, incluindo aí as mulheres, acaba tendo como decorrência uma opção familiar de mandar somente os homens para o acampamento, deixando para irem as mulheres e as crianças quando sai o assentamento definitivo. No caso do Sepé Tiaraju, várias mulheres afirmaram que se mudaram somente depois de homologado o assentamento, não participando de qualquer momento reflexivo. Esse procedimento, além de contribuir para eventuais desentendimentos futuros, contribuiu para o desmantelamento de algumas famílias, pois os homens vieram primeiro, e quando as mulheres não quiseram vir depois, levou à 
ocorrência, nesses casos, de divórcio ou, então, à desistência, por parte de seu companheiro, do lote.

Essa mudança de método também contribui para selecionar como participantes do acampamento aqueles que mais se adaptam a condições adversas, que têm menos laços sociais. Esse tipo de recrutamento facilita o ingresso de pessoas com vínculos menos estruturados, seja de família, trabalho ou mesmo vínculo social, ou seja, pessoas que podem mais facilmente largar tudo de uma hora pra outra. No caso do Sepé Tiaraju, é patente o grande número de pessoas sozinhas, em especial homens, sem família e sem laços sociais fora do assentamento, o que redunda em grande número de casos de alcoolismo, como veremos posteriormente.

O que se pode perceber na fala dos assentados, com relação ao tempo de acampamento, é que este é visto como um momento significativo e de transformação de suas vidas. De uma forma geral, a participação no MST permitiu aos assentados terem uma experiência de participação diferenciada. Eles tinham um objetivo comum, racionalmente refletido e que era, de certa forma, a soma dos interesses individuais de cada um deles. Os assentados em sua totalidade relembram com saudosismo e com uma certa nostalgia da época de acampamento, e se referem ao tipo de relacionamento diferenciado que eles tinham então, colocando em evidência a solidariedade que havia entre eles. Assim, Sr. Geraldo, assentado militante do MST, vai dizer que a época de acampamento:

era muito boa, que eles tinham união entre eles, diferente de agora. (...) Pegou fotos da época do acampamento para mostrar. Mostrou todo o processo: a ocupação, a ida para o sítio do Português, a ida para a linha do trem e novamente a ocupação (Diário de Campo, p. 98; 30/01/2007). 
A experiência de acampar e ocupar é muito significativa, se constitui como um momento de ruptura. Caldart (2004) afirma que o momento simbólico de romper a cerca, de cortar o arame, é um momento a partir do qual o sujeito não é mais o mesmo, não pode mais voltar atrás. Mais do que romper a cerca, ao ocupar uma propriedade, o indivíduo rompe com uma posição passiva, que remete a uma aceitação da mesmice, da eterna repetição do já dado, e se permite um momento de crítica com relação à situação que lhe é apresentada como imutável, possibilitando uma "recusa do existente, pela via da contradição e da resistência” (MAAR, 1995, p. 25), criando a possibilidade de tomarem em suas mãos a rédea de sua história, de fazerem seu próprio e diferente caminho. Segundo Sr. Ivan,

\footnotetext{
"As pessoas não olhavam assim, com aqueles bons olhos, porque é poucos que acreditam, porque... é só quem tá na luta mesmo que sabe que um dia vai ter resultado, que um dia vai ser... como é que fala... beneficiado com, com aquilo que ele acredita, entendeu? Eu acreditei, e muitos outros também acreditaram, e hoje tão no assentamento. [Com tanta gente contra, com a sociedade contra, o que fazia você acreditar que ia sair a terra?] Porque, que nem diz o nosso filósofo amigo Raul Seixas, sonho que se sonha só é apenas um sonho, sonho que se sonha com outros, que se sonha junto, acaba se tornando realidade." (Sr. Ivan, entrevista).
} 
Também são constantes as referências a uma mudança na auto-estima, no não se sentir mais humilhado ou inferior, no desenvolvimento da capacidade de pensar por si só. Segundo o que pudemos perceber, não só pelo conteúdo trazido nas entrevistas, mas no que pudemos observar no assentamento, essas mudanças se refletiram não só em questões políticas, como aprender a reivindicar seus direitos, questionando Prefeito ou Superintendente de órgãos públicos, mas também em pequenas situações do dia-a-dia, como exigir ser bem atendido no posto de saúde, exigir que o interlocutor fale olhando nos olhos do assentado.

\footnotetext{
"O que mudou ni mim é sabê que é possível ser dono do seu pensamento, falar com altivez, olhar pra cima e falar com qualquer pessoa de cabeça erguida. A cultura do Brasil tende a baixar a cabeça, as pessoas tendem a falar: 'sim senhor, sim senhor', baixar a cabeça. Dentro do Movimento, me deu a força de base... me deu a oportunidade de eu ser gente, ser humano pensante." (Sr. Vitor, entrevista).
}

Como também podemos perceber pelos exemplos acima, são claros os indícios de transformação de subjetividade nas pessoas que participaram da luta, bem como a transformação causada pelos momentos formativos que essa luta proporcionou: um dos assentados, por exemplo, conta que depois que ele entrou para o Movimento, ele deixou o alcoolismo, porque "bebia uma pinga arretada", mas parou, porque aprendeu a ser agroecológico, e se ele não dá veneno para as plantas, "porque iria colocar veneno dentro dele?" 
Cabe pontuar que ele está virando uma referência como produtor agroecológico, pois faz uma série de testes e tentativas, descobrindo novas técnicas. Os pesquisadores da EMBRAPA- Meio Ambiente realizam uma série de atividades no lote deste assentado, nas quais ele é o professor. Ele é usualmente entrevistado por rádios e televisões em programas de ecologia do país inteiro, bem como é procurado por pesquisadores da área de várias regiões do país.

Da fala do Sr. Vitor, transcrita acima, também podemos perceber que as pessoas saem de uma condição de seres humanos de segunda categoria, para os quais a posição nas relações assimétricas e de dominação era entendida como natural, como sendo de responsabilidade do próprio indivíduo que estava em posição de submissão; e passam a se ver como pessoas que têm valor, que são iguais aos outros, sendo que essa valorização se dá pela via do pensamento, da reflexão acerca da realidade.

Não é de menor importância o fato de experimentar isso de forma coletiva, ou seja, de terem tido uma oportunidade de reconstituírem-se enquanto indivíduos, de reorganizar sua subjetividade, a partir de uma experiência coletiva. O contato entre os indivíduos, proporcionado pela participação na luta pela terra, no grupo de pessoas acampadas, permite a identificação positiva com outros homens e mulheres, dando sentido e significado à experiência vivida, permitindo a criação de vínculos libidinais entre os indivíduos, para além da tarefa imediata, que é a participação na luta pela terra (ADORNO, 2006; FREUD, 1996).

A participação nesse tipo de grupo, o qual além de ter objetivos racionalmente escolhidos e que se sobrepõem aos objetivos heteronomamente determinados, permite a identificação positiva entre os indivíduos, contribue para a formação de relações recíprocas, a criação de vínculos afetivamente construídos, que se colocam no lugar das relações 
imediatamente utilitárias, isto é, aquelas mediadas pelo princípio do equivalente e pela mercadoria.

A participação na luta pela terra permitiu ao indivíduo ter uma experiência de si próprio como indivíduo singular, repensar sua história e seu lugar no sistema produtivo, ao mesmo tempo em que criam um significado coletivo e transformador da própria subjetividade. Lembrando Adorno e Horkheimer (1973, p. 71), “A proximidade estreita com outros homens e, por conseguinte, a afiliação em grupos que possibilitam o contato humano imediato, é uma condição óbvia do sentido de humanidade, de um modo geral". Nesse sentido, a participação em um acampamento do MST permitiu vivenciar a verdadeira igualdade, em contraposição ao igualitarismo repressivo imposto pela sociedade capitalista. Os exemplos de produção de uma identidade coletiva, na presente pesquisa, apareceram de forma contundente. Os assentados verbalizaram, em várias oportunidades, que na época de acampamento, eles se sentiam e se comportavam como sujeitos coletivos, pensando e agindo de forma coletiva:

“Eu já apanhei, já apanhei várias vezes da polícia nessa luta que nóis tá. Já apanhei na Pontal, já apanhei ni outros assentamentos, mas nem por isso eu desisti, que se fosse por mim, eu desistia, mas eu sabia que através de mim, eu era um número nessa luta nossa, ela é feita por número, de cada um, de um até o dez. Eu não disse pra você que a gente era... que a gente teve um acampamento com mil e setecentas famílias, mais de cinco mil pessoas? Lá nóis era mais de cinco mil pessoas!” (Sr. Arthur, entrevista). 
Houve a criação de um conteúdo coletivo, refletido e compartilhado, de uma significação coletiva da ação, ancorada em uma história comum que se estende por gerações. Na fala dos assentados, essa história tem relação com a história de outras épocas, tendo como atores não só os "lutadores do povo", mas também seus próprios antepassados familiares, não estando somente limitada ao período da luta. Segundo alguns assentados, eles passavam a pensar de forma coletiva, indo de um raciocínio fechado em si mesmo para um que contemplava os outros:

\footnotetext{
"Num primeiro momento, você luta pela conquista da terra, pra readquirir a cidadania, você luta pela reforma agrária, e aí você vai adquirindo mais conhecimentos, aí você luta por uma transformação social, de um outro país, de um novo mundo que seja mais adequado pra todas as classes, um mundo melhor. Então, essa é a transformação, você começa primeiro lutando pela terra, e depois por aquilo que é necessário para você ter uma vida melhor. Então o indivíduo não começa mais a pensar só nele, igual é lá na cidade, que você tem que ser melhor que todos, é só a sua sobrevivência, nessa caminhada depois você pensa de forma coletiva, no bem estar de todos. Então é isso que muda na vida da gente.” (Sr. Marco, entrevista).
}

A mística assume um papel essencial na criação desse sentido coletivo e histórico, tendo a função de relembrar e de identificar o indivíduo com as lutas realizadas por seus avós e pais, bem como identificá-lo com seu passado histórico enquanto povo: 
"A mística é pra buscar algumas coisas do passado, relembrar do passado, para que as pessoas relembra como foi com os seus avós, com os seus pais, a vida deles do passado. Que muitos não tem conhecimento, então a mística é pra fazer isso, fazer com que as pessoas relembra: 'puxa, meu pai, ou meus avós passô por isso'. Então isso é fundamental da mística, em todo local ter a mística... como que foi a questão dos índios aqui no Brasil, porque na verdade a... no Brasil, a terra não era nossa, ela era dos índios, então foi com os português que disse que descobriu o Brasil, que na verdade não descobriu coisíssima nenhuma, que acabo se tomando posse do Brasil, e nós acabô sendo uma mistura [...].” (Sr. Angelo, entrevista).

Participar do momento de luta no acampamento também possibilitou ao assentado confrontar-se com o diferente, levando-o à reflexão sobre sua forma de vida, sobre concepções, idéias e preconceitos que foram internalizadas como naturais e, que se não são superados, passam pelo menos a ser problematizados, fazendo com que o sujeito passe a se questionar. Assim, a luta representa uma ruptura com o sempre igual da cidade, com o já dado, bem como uma oportunidade de quebra da igualdade opressiva do modo de vida em nossa sociedade, da mesmice que cada indivíduo acaba por repetir no meio urbanoindustrial:

"Cê cai aqui pro mato, pra roça, entendeu, aí você tem que mudar muito os hábitos que tem na cidade, porque cê acaba entrando numa nova sociedade, entendeu? Então eu senti muita dificuldade. Chegava sempre aos sábados, eu ia pras baladas, pros clubes, tomá cerveja... aqui já senti 
uma diferença, $[. .$.$] até a forma de conversar, a forma de trocar idéia com$ um companheiro, com outro, era muito diferente. As idéias não eram as mesmas, de jeito nenhum. Na cidade você tem um jeito de conversar, um jeito de falar, um jeito de expressar, e quase todo mundo faz do mesmo jeito, e aqui você nota uma grande diferença, porque aqui você mistura com tudo... com tudo tipo de raça, cor, entendeu, então não tem... porque na cidade, querendo ou não, tem assim um certo tipo de preconceito, entendeu, na cidade tem preconceito... é... fulano é fulano, cicrano é cicrano, não se mistura, e quando se encontra no... nesse ambiente, que é uma nova sociedade... assim, do nosso Movimento... então, não tem aquela coisa de gênero, não se faz tanta questão de gênero, as tarefas são divididas praticamente de formas iguais, o homem pode lavar roupa, a mulher pode capinar e assim vai, assim vai a coisa, entendeu? Não tem aquela coisa de lésbica, gay, então são tratados todos como seres humanos. É que na cidade as vezes... até hoje existe esse tipo de preconceito, entendeu? Então a gente acaba caindo numa nova sociedade completamente diferente. Então até a gente acostumar com os hábitos dessa sociedade, que é a sociedade camponesa, né... então cê acaba... por mais que a gente tem uma raiz, que vem de raiz camponesa, mas criado individualmente, né, cê cai numa sociedade que é uma sociedade comunista, socialista, que é voltada para o meio ambiente, voltado para outro tipo de agricultura, cê acaba mudando muito até a forma de viver, a forma de expressar, então foi uma das grandes dificuldades que eu tive na época." (Sr. Ivan, entrevista). 
Do que vimos até o presente momento, podemos concluir que a participação no MST, na luta pela terra em seu período de acampamento, proporciona aos indivíduos uma possibilidade de rompimento do seu cotidiano reificado, permitindo que esses tenham uma experiência (Erfahrung) no sentido adorniano. A participação na luta estimula o pensamento livre e questionador, a capacidade para a reflexão, o desenvolvimento de uma auto-crítica, a consciência de que a atual configuração não é algo acabado e imutável.

O que antes era naturalizado é questionado através do pensamento esclarecido, e a adaptação a um mundo de dominação é rompido, bem como a naturalização da consciência heterônoma e o processo de repetição do "sempre-o-mesmo", que visava adaptar o indivíduo, sem questionamentos, ao todo social que o oprimia.

A participação em um acampamento, que fortalece o contato direto entre os indivíduos, possibilitou a criação de uma história e de significados compartilhados, o que acarretou no rompimento da alienação que separava os homens, que impediam que estes se reconhecessem como seres humanos. Essa construção de um sentimento de coletividade está fortemente ligada à possibilidade de experiência, que é ancorada num conteúdo coletivo e compartilhado.

Considerando que no mundo administrado, até mesmo a forma como as pessoas percebem as coisas é controlada, onde as pessoas têm somente vivências (Erlebnis), ou seja, apreendem o mundo e o que lhes acontece de forma não refletida, fragmentária e momentânea, sem integrar na consciência as percepções que lhe chegam de forma descontinua, individual e solitária, e na forma de clichês prontos para serem consumidos, a possibilidade de ter uma experiência, com as modificações que isto causa no indivíduo, é revolucionária. 
Assim, há um significativo impacto positivo nos indivíduos com a participação no MST, tendo em vista que esta proporciona uma possibilidade de reorganização da subjetividade, de escapar da vivência e de ter uma experiência e, como consequência, de passar por um processo de Bildung, de formação verdadeira, com o indivíduo modificandose pelo experimentado, passando a ter uma consciência de sua história e uma identidade coletiva, bem como se tornando capaz da auto-reflexão e do exercício do pensamento não condicionado, não heterônomo.

Como a experiência se caracteriza pela integração das percepções no ego, com a consequente mudança no mundo interno do indivíduo, a participação no MST permite, ainda que momentaneamente, romper com a fragmentação do sujeito, bem como com a alienação do indivíduo de si próprio. Assim, a participação no Movimento permite ao indivíduo trilhar o caminho no sentido de sua autonomia, de sua emancipação.

Se como diz Sigaud (2005), ao entrar para o Movimento, o indivíduo não está pensando na luta, mas em sobreviver, escolhendo uma entre as diversas possibilidades que ele tem, o indivíduo que sai da experiência de acampamento é diferente, é outro. Segundo o Sr. Ângelo,

"Não vou dizer que acabou ainda a revolta que eu tinha do passado, não gosto muito de falar disso, porque eu tinha uma revolta muito grande, por ver tanta exploração, tanta desigualdade, e a gente via que aquilo era uma situação muito difícil, para vários companheiros... a gente via os filhos de pessoas que podia... tendo seu bem estar, tendo seu próprio brinquedo, enquanto muitos não tinham nem o que comer. Então, com isso, o Movimento me ajudou a eliminar um pouco isso, não que ainda 
conseguimos, porque a classe excluída é muito grande, e tem um número grande de pessoas que ainda não entende isso daí, e a gente sabemos, que mesmo ainda com muita luta nossa, vai ser muito difícil a gente se unir toda a nossa classe excluída, pra gente se unir e lutar por sua liberdade e sua dignidade. Mas mesmo assim, posso dizer que eu mudei bastante, aprendi a ter um pouco mais de paciência, que com toda aquela revolta, se eu fosse fazer luta eu fazia luta à mão armada, não ia fazer uma luta pacífica (...), mas lutar pra vencer de mão armada mesmo, que eu achava que tinha que ser assim, e isso o Movimento me ensinou, que pra fazer luta não precisa ser mão armada, a maior arma será o nosso... ter um microfone na mão, é nóis conversando com o povo, tentando se unir, sensibilizar as pessoas, isso foi uma grande mudança para mim." ( $\mathrm{Sr}$. Angelo, entrevista).

Nos vários relatos feitos pelos assentados, podemos perceber que a participação num coletivo possibilitou a emergência de um sentimento de pertencimento, bem como possibilitou o fortalecimento da identidade dos indivíduos e de sua auto-reflexão.

Considerando que a experiência, para Adorno (1996, p. 403), é a "continuidade da consciência em que perdura o ainda não existente e em que o exercício e a associação fundamentam uma tradição no indivíduo", a participação no MST permite a aprendizagem e o exercício de lutar por fazer a sua própria história e a história do grupo, ao mesmo tempo fazer-se enquanto indivíduo nesse processo, bem como aponta para a possibilidade do não existente, criando uma perspectiva de futuro, da existência de um novo mundo onde as pessoas possam se realizar. 
Obviamente, a intensidade dessa experiência, bem como a extensão das marcas que ela deixou, variam de indivíduo para indivíduo, das condições objetivas a que foram submetidos cada um dos indivíduos em separado e como grupo; bem como da disponibilidade e capacidade de cada um desses sujeitos para a reflexão, para integrar essa experiência em seu mundo interno. A guisa de exemplo, uma das condições objetivas que variaram entre os sujeitos foi o tempo de experiência de acampamento, que como vimos, no caso do Sepé Tiaraju variou de seis meses a oito anos.

Cabe frisar, no entanto, que mesmo aquele que posteriormente se afasta do Movimento e da luta, não é o mesmo se comparado quando entrou. Um exemplo de mudança em alguém que hoje não se envolve mais com a luta, é o dado pela sra. Simone, que hoje toca seu lote no assentamento, e para quem

“[...] muitas coisas mudou, direitos que eu tinha, que eu não sabia que tinha, reivindicá os meus direitos, que você até acha... você até sabe que é um direito seu, mas você não sabe como reivindicá ele, então isso daí é uma das coisas que eu sou grata ao Movimento Sem-Terra, porque além de eu ter aprendido, hoje eu passo pras minhas filhas, porque por mais que elas estudaram, elas têm faculdade e tudo, mas elas não tinham conhecimento de que a gente podia chegar onde chegamos em questão de... eu mal estudei o primário, e eu não sabia que a gente tinha um monte de direito que era negado. Hoje eu chego num posto de saúde, e falo: quero ser atendida. 'ah, não tem vaga', porque em Serrana tem que agendar, tudo bem, mas 'olha pra mim, você está falando comigo', eu odeio conversar com uma pessoa e ela não olhar para mim." (Sra. Simone, entrevista). 
Se por um lado, eles se referem à dureza dessa época, por outro, lembram desse período com um certo saudosismo, referindo que eles eram mais unidos, se ajudavam mais, como podemos perceber pelo trecho abaixo. Havia uma vida coletiva intensa:

"Então, como... que eu sempre pensei no coletivo, por mais que a gente vive de formas diferentes hoje, como assentado, mas a discussão ainda é coletiva. Na época do acampamento era muito mais coletivo que agora. Porque até por necessidade obriga a ser coletivo. Então, é uma questão de sobrevivência, mesmo. Mas se nóis tivesse continuado naquele mesmo esquema, de coletivo daquela época, hoje nóis taria muito mais melhor, o assentamento estaria mais avançado, inclusive até as casas, estariam todas prontas, entendeu? Acho que tava um outro patamar de vida, entendeu?" (Sr. Ivan, entrevista).

Essa vida coletiva intensa foi diminuindo a partir do momento no qual eles se tornaram assentados. Com isso, há um sentimento de que se perdeu alguma coisa ao se mudar de acampamento para assentamento:

"Pouco a pouco perdeu a mística, essa é a verdade. É uma conclusão minha, e de muitos aí, entendeu... porque... era gostoso, você sentia mais... mais vivo na verdade, porque a mística é que deixa a gente mais... forte pra lutar." (Sr. Ivan, entrevista). 
A questão da solidariedade aparece no discurso de assentados e lideranças, e em pequenas manifestações de ajuda mútua no assentamento, no apoio aos companheiros de luta, na intenção de contribuir com os amigos da cidade, bem como quando se lembram do tempo de acampamento com saudosismo, falando do companheirismo que havia entre eles então. Segundo os assentados, a união era maior no tempo de acampado, e foi diminuindo depois que passaram a serem assentados. Com a efetivação do assentamento e com o passar do tempo, há um declínio paulatino das atividades coletivas e simbólicas, a despeito das tentativas do MST de mantê-las. Quase não ocorrem mais "místicas”, os coletivos passam a se fragmentar, bem como os espaços de discussão passam a se enfraquecer, e os indivíduos tendem a se isolar.

Com a transformação do acampamento em assentamento, os assentados dividiramse em núcleos, cada um mudou-se para o seu lote, e passaram a se ver com questões do diaa-dia, como a construção das casas, a organização/ reorganização das famílias, o início da produção, a necessidade da comercialização. Quando o indivíduo é finalmente assentado, após anos de luta, na maioria das vezes, está completamente descapitalizado, pois, como vimos, ele mal tinha recursos para se alimentar na época de acampamento.

Paralelamente a isso, há a entrada de novos atores no espaço do assentamento, atores esses que imporão exigências para o enquadramento dos assentados no acesso a seus programas de apoio e recursos financeiros. Soma-se a isso a pressão para produzir, para mostrar para a sociedade que o assentamento "dá certo".

Esses e outros elementos, que discutiremos nos tópicos seguintes, contribuem para fazer presente, dentro do assentamento, a lógica da mercadoria e a racionalidade instrumental, contribuindo para novamente adaptar o indivíduo à sociedade capitalista que ele aprendeu a questionar, fazendo com que a força da experiência, com sua aprendizagem, 
pouco a pouco fosse novamente substituída pela vivência. Dessa forma, "o que seria diferente é igualado. Esse é o veredicto que estabelece os limites da experiência possível" (ADORNO; HORKHEIMER, 1985, p. 26).

Tanto assentados quanto as lideranças do movimento social percebem esse processo, interpretando-o de formas diferentes e por vezes até antagônicas e, na quase totalidade das vezes, colocando a culpa desse processo nos indivíduos, conforme discutiremos quando olharmos para o assentamento e sua dinâmica relacional.

Por outro lado, também é importante pontuar que não se pode fazer uma idealização da época do acampamento. Havia uma dureza muito grande nas condições de existência nessa época, e muitos são os que saem do acampamento por essas condições. Na fala dos que ficam, isso é significado como uma demonstração de sua força na luta. O risco à sobrevivência física também está sempre presente, e no discurso dos assentados ele aparece como o risco da fome, bem como o risco da violência física (agressões, tiros ou colocarem fogo no barraco enquanto eles estão dormindo dentro) por parte de parcelas da sociedade que não apóiam o Movimento.

Outrossim, mesmo nessa época, há indicativos de que já havia uma assimetria nas relações de poder entre assentados e liderança. Alguns assentados vão falar em um autoritarismo da liderança, que os acampados toleravam para não perder a chance de ter a terra. Alguns acampados teriam sido expulsos ou saído do acampamento em função dessa postura autoritária de algumas das lideranças: 
"Porque aqui, antes de virar lei, antes da gente assinar o SIPRA ${ }^{6}$ da gente, muitas famílias foi embora daqui por ameaça deles, porque tinha que ser do jeito que eles queriam. Então muitas famílias que não podiam ter ido embora, ficou muitos anos debaixo da lona, perdeu o tempo deles, e eu sou triste com a direção do MST aqui na região, por causa disso.” (Sr. Arthur, entrevista).

Há indicativos de que os sujeitos não se colocavam completamente nas reuniões ou fóruns públicos, mesmo naqueles nos quais se decidiam elementos que certamente seriam decisivos na organização da vida daqueles indivíduos no assentamento, como com relação à divisão da área do Sepé Tiaraju. No presente caso, no entendimento de vários assentados, principalmente para aqueles que chegaram posteriormente, a opção pela Comuna da Terra já estava dada, e quem não queria tinha que mudar para outro acampamento, e alguns verbalizam que aceitaram esse tipo de divisão de lote a contragosto para não protelar seu ingresso em um assentamento e para não terem que mudar para outro acampamento mais longe de Ribeirão Preto.

Cabe pontuar que o comportamento dos acampados é grandemente influenciado pela possibilidade de conseguir ou de perder a terra, ou seja, seu comportamento é em grande parte determinado por seu objetivo final, portando, dessa maneira, elementos de um utilitarismo e de uma racionalidade instrumental. Nesse sentido, vários teóricos vão dizer que no acampamento, os indivíduos apresentam um comportamento diferente do que

\footnotetext{
${ }^{6}$ SIPRA - Sistema de Informações de Projetos de Reforma Agrária, trata-se de um sistema informatizado mantido pelo INCRA, que registra todo aquele que é assentado, seja em assentamentos federais, seja estaduais e municipais. Cada família assentadas recebe um número, sendo considerada oficialmente assentada com o seu cadastramento nesse sistema, e a partir daí passa a ter direitos a uma série de programas federais, como o PRONAF e o crédito habitação.
} 
tinham antes (bater na mulher, beber pinga) por medo de serem excluídos e não por tomada de consciência, voltando a apresentar esses comportamentos quando são assentados (TURATTI, 2005; LEITE; DIMENSTEIN, 2006). Ademais, voltamos a pontuar que a experiência não é igual e nem a mesma para todos, e justamente por causa disso que ela é experiência.

\subsection{O assentamento Sepé Tiaraju}

A primeira ocupação na Fazenda Santa Clara, que posteriormente originou o assentamento Sepé Tiaraju, ocorreu no dia 17 de abril de 2000, e o assentamento foi oficializado em 20 de setembro de 2004 (SCOPINHO et al., 2007). A inauguração oficial ocorreu no dia 12 de dezembro de 2007. O nome Sepé-Tiaraju faz referência a um índio da etnia guarani, da região das Missões (RS), que lutou para defender seu povo da escravidão.

O assentamento ora estudado procura combinar formas de organização coletiva com espaço para atuação individual, dentro do modelo que o MST denomina Comuna da Terra. As 80 famílias se dividem em quatro núcleos-base com vinte famílias cada, esses núcleos receberam os nomes de Chico Mendes, Dandara, Zumbi dos Palmares e Paulo Freire.

Há uma área coletiva destinada à construção da área social das oitenta famílias, bem como um espaço onde estão localizados os prédios pertencentes à antiga sede da Fazenda Santa Clara. Esses prédios, em estado bastante precário de conservação, foram adaptados para serem usados como escola e "secretaria". Outro prédio existente teria sido desfeito pelos assentados para utilização dos tijolos na época do acampamento. Além da área social 
comum às oitenta famílias, há quatro outras áreas coletivas destinadas à área social de cada um dos núcleos-base.

$\mathrm{Na}$ área destinada à construção da área social, pretende-se construir estruturas que contribuam com a convivência social dos assentados, com o seu lazer e com o desenvolvimento de atividades culturais, como campo de futebol, centro comunitário e igreja, bem como estruturas para a prestação de serviços públicos e sociais, como posto de saúde.

A área coletiva destinada à produção também segue essa lógica: há uma área de produção coletiva para as oitenta famílias, a ser gerida em conjunto pela coordenação geral do assentamento, através da sua pessoa jurídica, a Agro-Sepé; e quatro áreas coletivas, uma para a produção coletiva de cada núcleo.

As áreas de plantio coletivo para cada um dos núcleos de base têm sessenta hectares (CONCRAB, 2004; Diário de Campo, p. 3). No entanto, como podemos observar pelo mapa (anexo), as áreas marcadas como plantio para cada um dos quatro coletivos é pequena, estando por volta de doze a quinze hectares. Assim, parte da reserva legal foi considerada área de produção de cada um dos núcleos, e para manejá-la, os assentados terão que plantar agrofloresta.

O assentamento conta hoje com 797,75 hectares, sendo 280 hectares de reserva legal, 83,45 hectares de Área de Preservação Permanente (APP), 49,57 hectares cedidos ao MST para construção da sede regional do MST e de um colégio técnico agrícola, e 293,65 ha destinados aos lotes individuais. Assim, cada uma das famílias assentadas conta com cerca de 3,6 hectares de lote individual, que se destina à construção da moradia e para produção individual/familiar. 
Outro dado a ser observado é que no documento de cessão de área para os assentados, cada parceleiro tem oficialmente de 9,97 hectares individuais, quando na prática tem aproximadamente 3,6 hectares individuais. Segundo técnicos do INCRA, o parcelamento não foi feito no papel, mas feito socialmente pela comunidade, e a área destinada ao plantio coletivo, à construção da sede regional do MST e do colégio, as áreas de reserva legal, as APPs, constam como tendo sido divididas entre os assentados:

Helena (técnica do INCRA) começou a distribuir e pegar as assinaturas no Contrato de Concessão de Uso ${ }^{7}$. Segundo o que ela explicou ao ser questionada por um dos assentados, a área foi dividida no papel em tamanhos iguais para todas as famílias (9,97 hectares); e a divisão das áreas individuais e áreas coletivas, que é como se configura o assentamento na realidade, existe de forma não registrada/oficial. As pessoas assinaram como se a área coletiva não existisse, e fosse usada por famílias. (Diário de Campo, p.63, 14/12/2006).

Essa situação já tem causado certos desentendimentos entre os assentados e a liderança do MST. Os assentados começam a questionar a própria divisão dos lotes, falando entre eles que no documento do INCRA consta que cada família tem direito a nove hectares. Alguns assentados já falam abertamente em dividir os lotes de acordo com a metragem que eles detém oficialmente, ou seja, em dividir toda a área do assentamento de acordo com divisão oficial, eliminando-se as áreas de produção coletiva, que deveriam

\footnotetext{
${ }^{7}$ Contrato de Concessão de Uso: contrato assinado entre o INCRA e cada uma das famílias assentadas, no qual o governo federal concede o direito de uso daquela parcela de terra (o lote), e no qual as famílias assentadas declaram estar de acordo com as condições de uso, bem como com cumprir as obrigações definidas nesse contrato.
} 
então ser constituídas de acordo com a combinação entre os próprios assentados, segundo a divisão por "grupos de afinidade".

De passagem, pontuamos que a mesma legislação que proíbe a existência de latifúndio, o Estatuto da Terra (Lei 4504 de 30 de novembro de 1964), proíbe também a existência do chamado "minifúndio", que são propriedades rurais com tamanho menor do que o módulo fiscal, e que não são suficientes para o desenvolvimento sustentável de uma família. O módulo fiscal varia de região para região, e depende da fertilidade e topografia do solo, do clima, e de outros indicadores agronômicos. No caso de Ribeirão Preto, o módulo fiscal está em torno de 10 hectares, mas pode sofrer pequenas variações de um imóvel para outro (INCRA, 1997). Em tese, o governo federal não pode parcelar a terra em tamanhos menores do que o módulo fiscal, o que inviabiliza a divisão oficial do assentamento com apenas 3,6 hectares por família.

Se o governo federal outorgou para cada parceleiro o direito de uso e posse de 9,97 hectares, segundo o que consta nos documentos públicos oficiais, por outro lado, a divisão dos lotes e demarcação das áreas coletivas foi feita pelos técnicos agrimensores do INCRA, em divergência com o que consta nos documentos do próprio órgão.

Nesse sentido, o governo federal demonstra uma posição ambígua e uma relação confusa com os assentados e com o movimento social, que posteriormente discutiremos. $\mathrm{Na}$ prática, o INCRA desconsiderou a legislação e seus próprios registros oficiais, disponibilizando seus técnicos para colocar em prática uma divisão da área do assentamento que esbarra em questões legais para existir oficialmente. Por outro lado, o documento oficial fornece subsídios para alimentar as discussões e conversas paralelas que versam sobre a área disponível para cada assentado trabalhar com a sua família. 
Com relação a isso, os assentados, mesmo aqueles ligados ao MST, como o que emitiu a opinião que transcrevemos abaixo, se dizem insatisfeitos com o tamanho da terra que coube às famílias. Há uma tendência patente de que o assentamento caminhe no sentido da divisão dos lotes, no modelo que o Movimento chama de "individual", ou seja, no lote trabalhado de forma familiar. Segundo conta o Sr. Flávio

\footnotetext{
'Aqui, no começo, o combinado não era ser parte individual e parte coletivo, era pra ser tudo individual. Se eu soubesse que ia ser assim, não tinha vindo, não tinha saído do acampamento que a gente tava. [Mas como foi decidido ser coletivo?] Foi em reunião, quando a gente tava decidindo como ia ser o assentamento, como ia ser dividido. O INCRA mais a liderança falaram que na universidade tinham estudos que falavam que três hectares e meio dava pro sustento de uma família. Eu tô pra ver isso, três hectare e meio é muito pouco, pouca terra. No Carlos Lamarca [assentamento ligado ao MST, na região de Itapetininga] o lote é maior... se bem que eu ouvi dizer que a terra é mais ruim...' (Sr. Flávio, Diário de Campo, p. 67, 11/01/2007).
}

Nesse sentido, cabe pontuar um posicionamento também confuso e contraditório dos assentados: vários deles manifestaram que discordavam, desde a época do acampamento, com a divisão de lotes que foi consensada nas várias reuniões de discussão da organização do assentamento. No entanto, não se colocaram explicitamente contra a proposta, e não disputaram seu projeto nos fóruns públicos, em função de não quererem protelar a obtenção do seu lote. 
Outro questionamento que tem aparecido com frequência, que os assentados falam entre si e, segundo alguns deles, inclusive já foi falado para a própria liderança, é a área destinada para a construção da Sede Regional do MST e de uma escola técnica agrícola ligada ao Movimento. Os dados são contraditórios: no mapa editado pelo INCRA, consta cerca de 50 hectares com esse fim, já alguns assentados e a liderança falam que os primeiros teriam cedido cerca de 100 hectares para o MST. No entanto, o que os assentados comentam entre si, é que não cederão mais aquele espaço em específico, pois a terra ali é de melhor qualidade, e que o MST deve construir sua sede em outro local dentro do próprio assentamento (o sítio do Sr. Luiz Português, por exemplo), e deixar aquela área para produção. Alguns assentados, os mais críticos à atuação do MST dentro do assentamento, chegam a falar que não houve consenso quanto à cessão de nenhuma área para o Movimento, conforme aparece na fala abaixo:

Começaram a falar na divisão da área (3,6 hectares), falar da falta de escola, de área social, que o Estado não faz. Pergunto da escola técnica agrícola que vai ter na área que eles cederam para o MST. Eles imediatamente responderam: "Nós cedemos? Onde está escrito isso? Eles nem tocam mais nesse assunto aqui dentro, porque sabem que vão ouvir. Quero ver eles falarem alguma coisa, em construir lá, vamos ver se isso passa em assembléia do assentamento. Isso é combinação do MST com o INCRA, não tem nada com a gente!” (Diário de Campo, p. 200, 16/06/2008). 
Até o ano de 2008, a maioria dos assentados vivia no que eles chamam de "barracos". A maior parte dos assentados vive hoje em casas de alvenaria, construídas com recursos da Caixa Econômica Federal e do INCRA, através do sistema de mutirão. Alguns assentados ainda não terminaram as suas casas, vivendo ainda nos "barracos". No início da pesquisa, todas as famílias viviam nesse tipo de moradia, que na verdade já eram "barracos" bastante elaborados, com alguma das paredes em alvenaria, principalmente no banheiro. Alguns poucos casos tinham ainda uma das paredes feitas de lona plástica, presa com uma estrutura de ripas de madeira, mas na maior parte das residências, as paredes eram feitas de madeira, compensado de virola ou lâminas de tetrapac, com janelas e portas rudimentares.

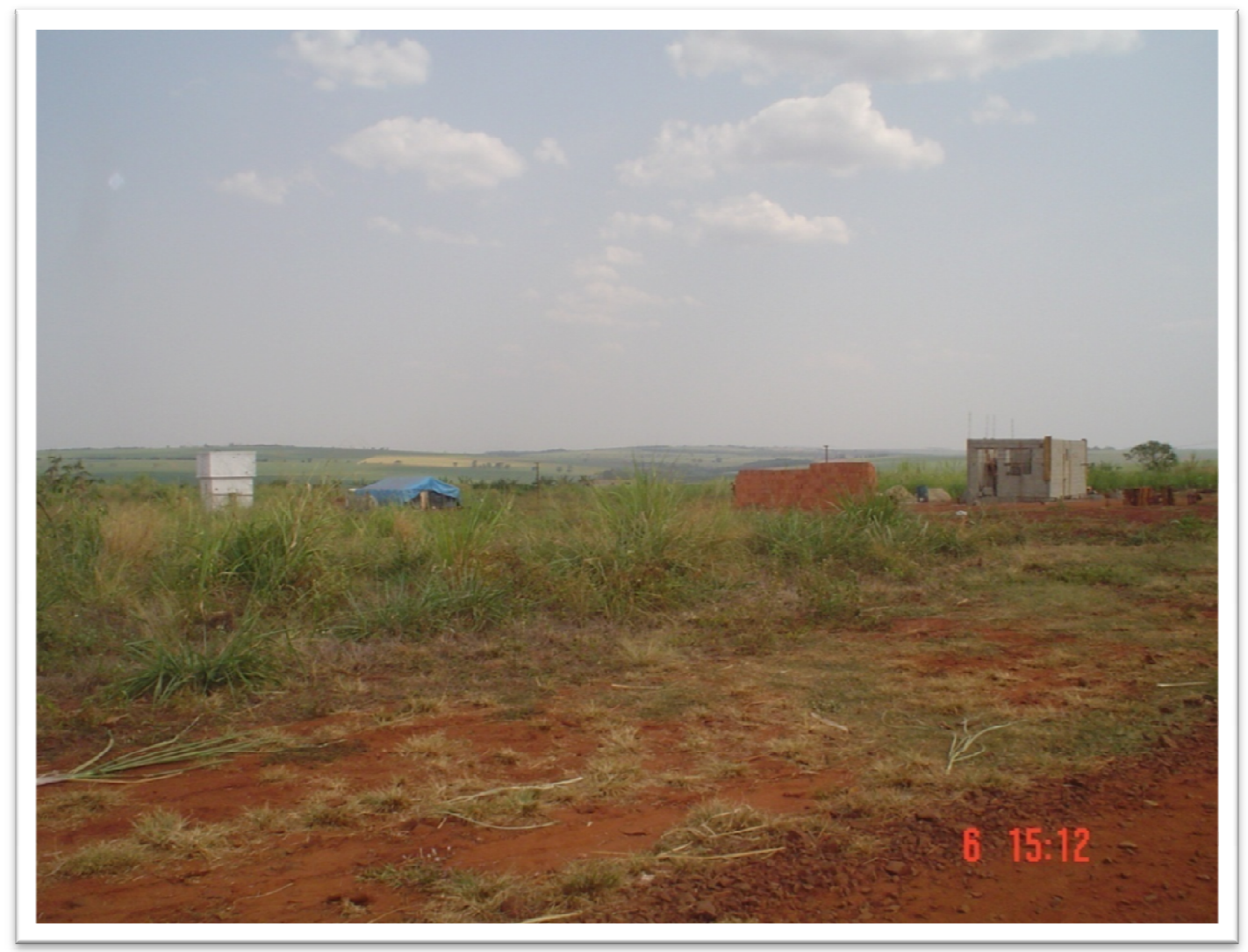

Figura 1: vista parcial da área comum, com um "barraco" de lona e uma moradia sendo construída. 
Um dos maiores problemas que ainda é sentido pelas famílias dentro do assentamento é a falta de água. Existem três minas (nascentes de água) dentro da área do Sepé Tiaraju, e os assentados puxam água através de um extenso e complexo sistema de mangueiras. Como são quatro núcleos, cada um deles recebe água em dois dias da semana, faltando água nos demais. No caso dos três núcleos do lado esquerdo da pista, no sentido Ribeirão Preto - Serra Azul (Paulo Freire, Zumbi dos Palmares e Dandara), especialmente os dois últimos, mesmo nos dias em que recebem água, há assentados que têm que caminhar até quatro quilômetros para busca-la com um balde, já que o ponto final da mangueira fica em uma das ruas do núcleo Paulo Freire. A falta de água traz dificuldades para todas as áreas, não só para as atividades do dia-a-dia, mas para a produção, para a construção de casas e para o trato dos animais.

\footnotetext{
“Aí eu falei pro promotor: doutor, como é que nóis pode receber dinheiro pra plantar se a gente não tem água, se a gente vai buscar água com uma distância de três quilômetros num balde de vinte litros na cabeça, quem tem carroça busca na carroça, quem tem bicicleta, de bicicleta, quem não tem busca a pé? Como aqui é um assentamento modelo, e falta a água? (...) Nós já tamos pra quatro anos que foi aqui decretado um assentamento. Pro governo federal, com menos de dois anos já era pra ter ponhado o essencial aqui dentro (...)" (Sr. Arthur, entrevista).
}

Um dos objetivos do MST ao se trabalhar dentro dos assentamentos, e que é pontuado pelos assentados como muito importante, é a necessidade de se continuar a luta, 
ou seja, de continuar mobilizado após o assentamento. Segundo os assentados, o enfoque da luta muda um pouco, deixando de ser a obtenção da terra, já que essa foi conquistada, e passa a ser a manutenção dessa terra, tendo-se em vista que os assentados começam a viver em uma terra inóspita e sem as mínimas condições de existência e nem de trabalho.

Quando tomaram posse da fazenda na qual seriam definitivamente assentados, já com a emissão da posse no nome do INCRA, os assentados lembram que não existiam as menores condições de sobrevivência, que nem montar os barracos era possível, tendo-se em vista que a fazenda estava recém-colhida da cana, e que havia os toquinhos da planta por todos os lugares, e assim os mais novos proprietários da terra não tinham nem onde dormir. No espaço do novo assentamento, não havia casas, não havia ruas, e nenhum serviço público de suporte àquele novo assentado. Segundo os próprios assentados, ao homologar o assentamento, o governo coloca-os na área da fazenda, espera que eles vivam e produzam ali, e não "dá água, não dá casa, não dá crédito para plantar”, e que o início do assentamento "tinha que ser um negócio assim, mais adiantado" (Sr. Geraldo, Diário de Campo, p.100, 30/01/2007).

“[...] Lutar pela benfeitoria, pela produção, a luta é constante, nós apenas estamos em outra etapa. [...] As coisas são morosas, você tem que lutar contra a burocracia, aí quando chega o recurso já passou da hora de plantar, dependendo da região em que você está, então é uma luta constante." (Sr. Marco, entrevista) 
Ainda hoje, após quatro anos de assentamento, há uma falta generalizada de infraestrutura básica. O assentamento não tem espaços coletivos, isto é, a área deixada para construção dos edifícios para vivência coletiva está vazia. Durante o desenvolvimento da presente pesquisa, foi construída a casa das freiras ali, bem como se iniciou a construção de uma Igreja Católica em forma de barracão, que pode eventualmente ser utilizada como área comunitária, dependendo da orientação do padre responsável pela diocese. Não há espaços de lazer, de convivência comunitária, de cultura, de saúde ou de educação.

As reuniões para discutir e organizar o assentamento, sejam elas eventuais ou regulares, são realizadas ou em uma antiga escola da fazenda, cujo teto está caindo, ou embaixo de uma árvore, ou em uma casa emprestada.

Durante o trabalho de campo, foi instalada a energia elétrica para servir as casas, de forma particular. Não existe iluminação pública nas ruas do assentamento, e a noite, as pessoas têm que se locomover com lanterna.

Para frequentar a escola, as crianças e adolescentes recorrem, na maioria dos casos, às escolas de Serra Azul, município onde se localiza o assentamento. A prefeitura disponibiliza o transporte, através de um ônibus que percorre o Sepé Tiaraju, para buscar e trazer as crianças.

O atendimento de saúde também é realizado, prioritariamente, no município de Serra Azul. Os assentados também recorrem aos serviços médicos de Serrana e de Ribeirão Preto, para casos de maior complexidade. Há um serviço de ambulância, fornecido pela prefeitura de Serra Azul, que busca os pacientes no assentamento para transportá-los para o município, ou para Ribeirão Preto, com agendamento prévio. 
Com relação ao entorno do assentamento, ele está inserido como uma pequena ilha no meio da cana, quebrando não só a monotonia da paisagem, como também a lógica agrícola da região, dominada pelo latifúndio produtor de cana.

O Sepé Tiaraju alterou significativamente a paisagem, e nota-se que "o assentamento como um todo está com a plantação grande, formada, pintado de tons de verde diferentes, com árvores, muito diferente da paisagem do entorno, que é de um verde monótono da cana." (Diário de Campo, p. 99).

Em consonância com os princípios do Movimento colocados para a organização de um assentamento, e na mesma direção dos compromissos afirmados no V Congresso Nacional do MST, o assentamento Sepé-Tiaraju adota um modelo agroecológico de produção. Nesse aspecto, o primeiro impacto é ecológico: a capoeira está crescendo de novo, as nascentes que ameaçavam secar continuam fornecendo água para os assentados, o morro que fica dentro da área do assentamento está sendo lentamente reflorestado pela capoeira e por algumas poucas mudas de árvores nativas que foram fornecidas por pessoas da sociedade civil ligadas à luta pela reforma agrária.

Os assentados e a liderança local falam no reaparecimento de animais e na reconstituição da fauna: quando entraram na área do assentamento, não havia nem mosquitos, quando começaram a plantar de forma agroecológica, os insetos foram os primeiros a aparecer, incluindo formigas que já não existiam mais na área; no ano seguinte vieram os pássaros, seguidos de animais maiores. 


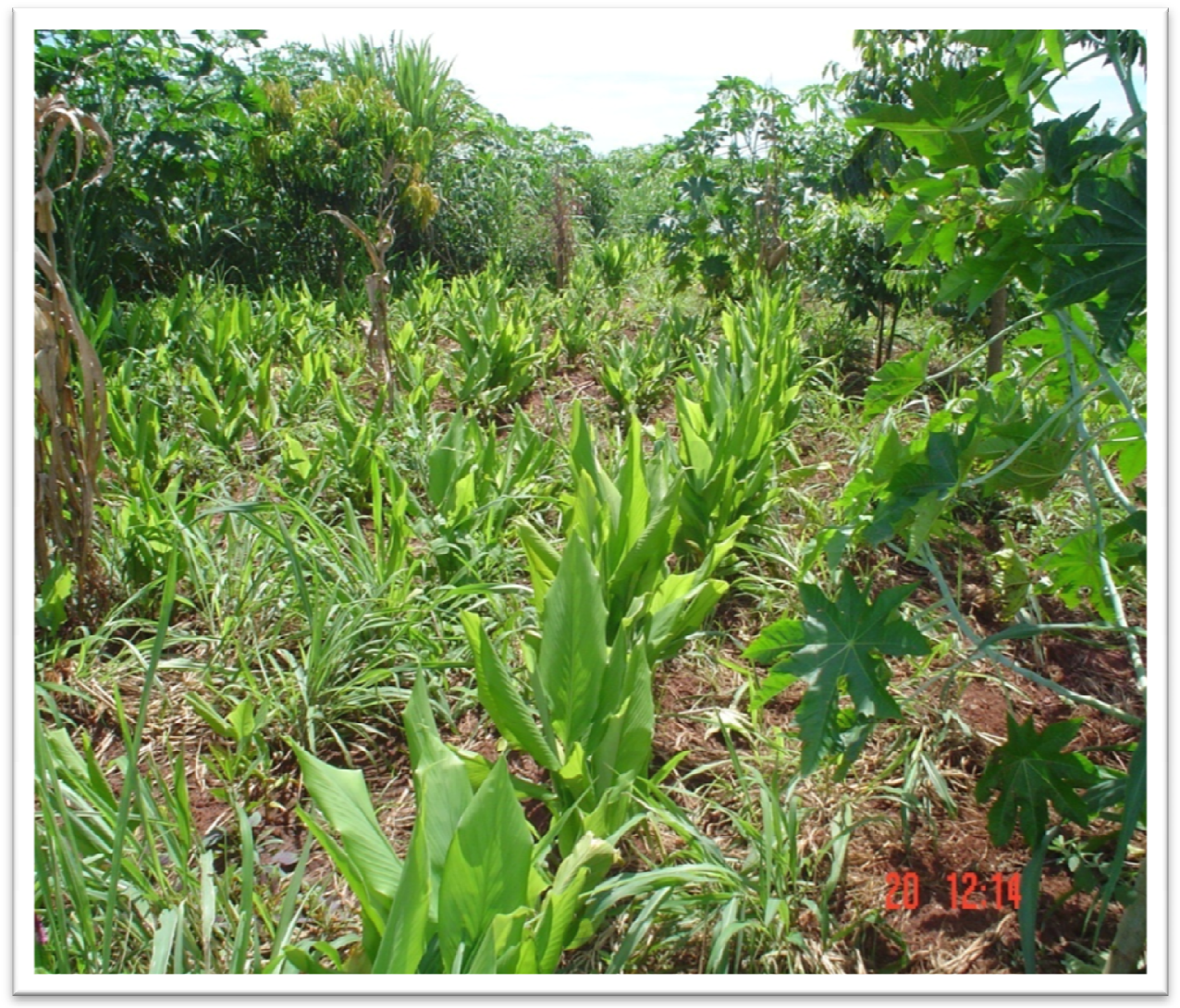

Figura 2: plantação de açafrão no sistema de agrofloresta (consorciado com outras plantas).

Mesmo boa parte dos assentados que não tinha uma tradição agroecológica assumiu essa aprendizagem e esse discurso. Na discussão para "cortar na corda" 8 a área de uso comum dos oitenta, a primeira preocupação dos assentados na reunião era a de demarcar as fontes de água, deixando um espaço bem grande em volta, bem como as áreas de Preservação Permanente e de agrofloresta comunitária.

Por outro lado, há alguns assentados que não internalizaram esse modelo. Esses verbalizam que se sentem obrigados a plantar de forma agroecológica, quando desejam plantar da maneira convencional. Um exemplo desses assentados é o Sr. Fernando, que em

\footnotetext{
8 "Cortar na corda" trata-se de um procedimento tradicional de divisão de áreas de plantio, usada pelos agricultores, que utiliza uma corda como régua, com a função de definir o tamanho e as linhas divisórias de uma área para outra.
} 
uma das visitas feitas ao seu lote, reclamou de não poder plantar semente do tipo comercial (híbrida), que dá duas ou três espigas por pé, e ser "obrigado" a plantar semente crioula, que "dá somente uma espiga por pé, quando dá” (Diário de Campo, p. 95).

Segundo alguns assentados que desejam plantar de forma agroecológica, a resistência de seus companheiros se deve à falta de formação e de preparo para trabalhar nessa nova maneira, que exige bastante dedicação e conhecimentos específicos para manejar adequadamente a plantação e não perder a produção.

Hoje são cultivadas no Sepé lavouras das mais diversas espécies, de acordo com o gosto e a aptidão de cada assentado. Destacam-se a agrofloresta, que está sendo plantada por um número significativo de assentados, o milho, a mandioca e o feijão, além de pequenos animais, como galinhas.

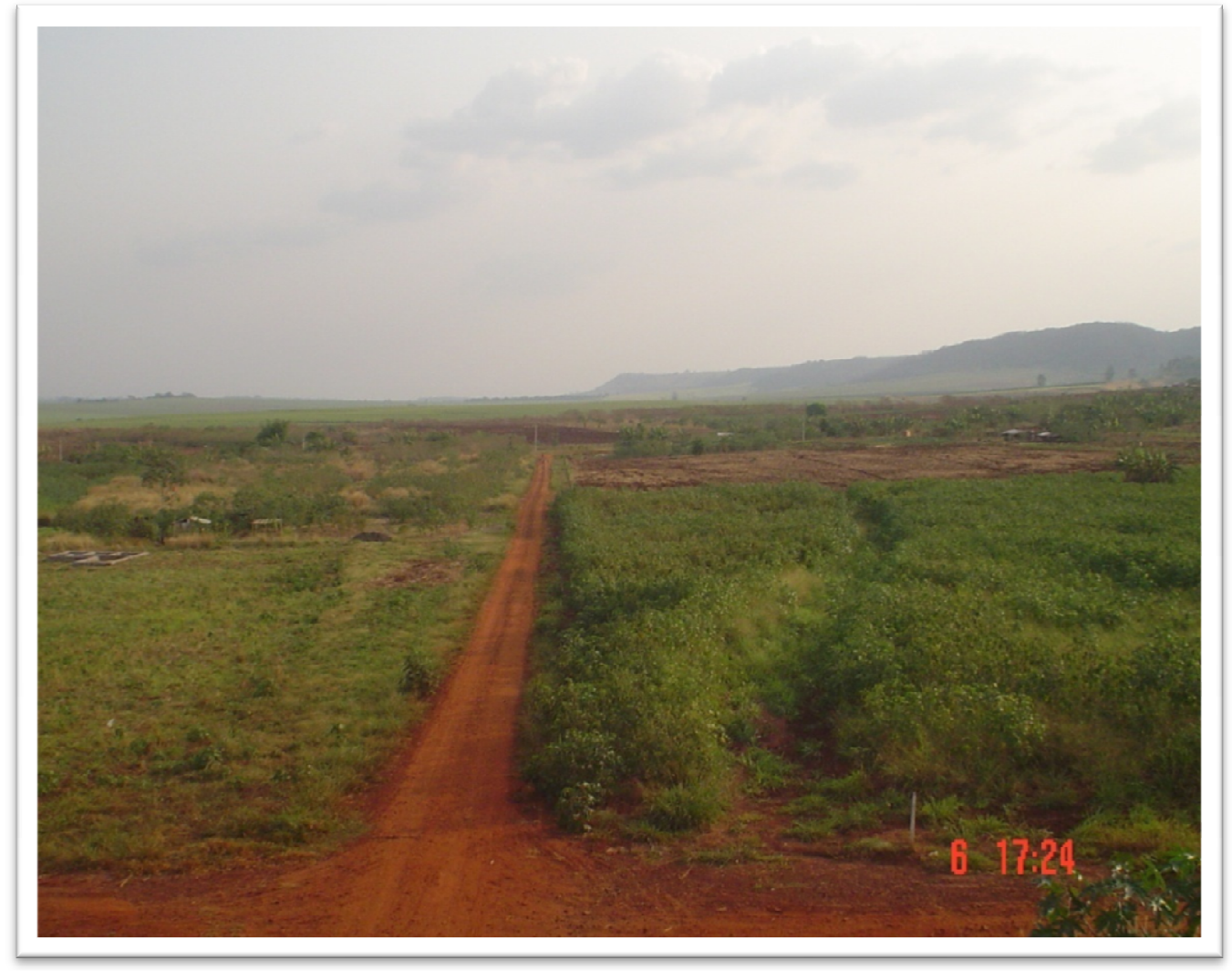

Figura 3: vista geral do assentamento Sepé-Tiarajú. 
Os assentados produzem hoje uma grande quantidade de alimentos de qualidade, que são comercializados na região. Comerciantes de toda a região vêm adquirir os produtos orgânicos no assentamento, inclusive da cidade de Cajurú, que é um pouco mais distante (cerca de 40 kilometros), para venderem em seus comércios.

Há ainda comerciantes de locais mais distantes que adquirem produtos no assentamento, de forma eventual, como um senhor que utiliza subprodutos de produção agrícola para fazer artesanato (palha de milhos, buchinha vegetal), os quais vende posteriormente para grandes redes de supermercado e para redes de postos de estradas.

Os consumidores finais também acabam por fazer compras diretamente no assentamento, em especial nas barraquinhas montadas ao longo da rodovia Abrahão Assed, que corta o assentamento, mas há também um grande número de pessoas que se dirige às casas dos assentados. Esse tipo de comercialização, feita diretamente dos assentados para o consumidor final, elimina o atravessador e faz chegar alimentos de qualidade na mesa da população local.

Os assentados também utilizam como uma estratégia de comercialização a venda direta nas cidades de Serrana e Serra Azul, para onde se deslocam de carro ou de perua Kombi, e oferecem seus produtos aos moradores, passando de carro de rua em rua.

Apesar de todas essas formas de comercialização realizada pelos assentados, essa continua sendo ainda um grande problema para o agricultor familiar. A comercialização, como em outros assentamentos, tem sido a principal dificuldade com relação à produção. Os assentados produzem consideravelmente, mas têm encontrado problemas para vender. Muita coisa se perde, ou quando conseguem vender, o preço acaba não compensando, e não há retorno financeiro. 
Parte significativa da produção é vendida para a Companhia Nacional de Abastecimento (CONAB), órgão do governo federal que executa alguns programas de compra de alimentos do produtor rural agricultor familiar, sejam eles assentados ou produtores tradicionais. No ano de 2007, os assentados do Sepé venderam boa parte da produção para um desses programas, o Programa de Aquisição de Alimentos - PAA, do MDA (Ministério do Desenvolvimento Agrário) e do MDS (Ministério do Desenvolvimento Social), operacionalizado pela CONAB, modalidade “doação simultânea", no qual os produtores vendem para o governo o produto, que o repassa a entidades assistenciais públicas e privadas. Esse programa garantiu um certo retorno para os assentados. Segundo dona Simone, assentada no núcleo Chico Mendes, o programa da CONAB

[...] estava sendo bom, que ela tinha umas abóboras maduras [...], que já tava quase perdendo, então ela foi falar com a Vânia [liderança regional do MST, responsável pela intermediação dos assentados com a CONAB], pra ver ser a CONAB pegava abóbora, achando que não pegava ('quem ia querer abóbora?'), a Vânia disse que pegava abóbora sim, e Dna Simone vendeu mais de uma tonelada de abóbora, pegou mais de mil reais, e com esse dinheiro comprou uma vaca (Diário de Campo, p. 144; 08/06/2007).

Se o Programa de Aquisição de Alimentos da CONAB é visto como positivo, os assentados, por outro lado, reclamam que o volume de compras destinado a cada produtor, regulado através do sistema de cotas, é muito pequeno. Boa parte dos assentados atingiu sua cota já na primeira venda realizada, no início do funcionamento do programa. O 
primeiro dado que isto indica é a grande produtividade do assentamento. Ainda que não haja dados numéricos no presente assentamento para confirmar tal assertiva, foi largamente constatado que as famílias produzem uma quantidade bastante grande de produtos e, como já dissemos anteriormente, inclusive encontram dificuldade para vendê-los.

A pressão social pela produção é bastante grande. Os próprios assentados verbalizam constantemente que têm que produzir em grande quantidade para mostrar que o assentamento dá certo, ou para retribuir à sociedade o apoio que tiveram na luta e na obtenção da terra, produzindo alimentos de qualidade para a cidade. Nesse sentido, o discurso do MST, que coloca como um dos objetivos da reforma agrária o cumprimento da função social da terra, encontra respaldo em quase a totalidade dos assentados.

Os próprios assentados acabam por pressionar aqueles que não produzem da forma e na quantidade que eles julgam adequada e suficiente. Socialmente, aqueles que não produzem como os outros sofrem inclusive uma certa discriminação, sendo alvo de comentários e apelidos como "Fulano Lambão", e sofrendo inclusive intervenção do seu grupo de trabalho coletivo, como no caso de um senhor cujo lote não estava todo plantado, bem como ele estava ameaçando arrendar o lote para um produtor de Serra Azul. Por causa disso, e diante da ameaça do INCRA de excluí-lo, o "grupo de afinidade" de PRONAF" (Programa Nacional de Fortalecimento da Agricultura Familiar, empresta dinheiro com taxas de juros abaixo do mercado para financiar a produção agrícola) do qual ele participava, fez uma reunião com ele e com os técnicos do INCRA, e resolveram plantar

\footnotetext{
${ }^{9}$ Quando passam a ser assentados, os indivíduos passam a ter acesso a algumas linhas de recursos federais para a construção da casa, organização inicial da vida no assentamento, investimentos iniciais necessários à produção, e recursos de custeio de safra. Alguns desses recursos são a 'fundo perdido', ou seja, não precisam ser pagos posteriormente. Outros recursos se configuram como empréstimo, tendo um período de carência para o início do pagamento. O PRONAF é uma linha de crédito de financiamento, que se subdivide em várias modalidades, entre elas o "custeio de safra", que pode ser acessado várias vezes, e o "investimento", para a formação inicial do lote.
} 
para ele o lote, revertendo $30 \%$ do resultado da produção para o assentado proprietário do lote, e dividindo $70 \%$ entre aqueles que iam trabalhar no lote dele (Diário de Campo, p. $171,28 / 06 / 2007)$.

Outro aspecto que não pode deixar de ser frisado é a importância do assentamento na dinamização política e econômica local. O primeiro ponto a ser ressaltado é a importância simbólica de sua criação em uma área tradicionalmente conhecida pelo agronegócio, em especial pela produção monocultora de cana de açúcar para produção de álcool etílico e de açúcar.

Como já pontuamos anteriormente, a criação do Sepé Tiaraju tem um impacto bastante grande na dinâmica e no imaginário da população local, em função dos questionamentos às estruturas reinantes, bem como por representar uma outra possibilidade para as populações pobres da região, que não tinham outra alternativa a não ser submeterem-se ao trabalho forçoso na cana-de-açúcar.

Um acontecimento curioso que observamos durante o desenvolvimento da pesquisa, e que ilustra a situação sui generis provocada pela presença de um assentamento na região causa, ocorre em um dia no qual um ônibus de bóias-frias, que deviam estar cortando cana em uma das muitas áreas cobertas por esta cultura, que rodeiam o assentamento, parou ao final da tarde na entrada do Sepé Tiaraju. O motorista desceu do ônibus para comprar legumes e verduras orgânicos que são vendidos em uma das barracas montadas ao longo da rodovia Abrahão Assed, sendo que esta em específico pertencente a uma associação de produção ligada ao MST, e que produz de forma coletiva. Somente o motorista desceu do ônibus, mas os bóias-frias que estavam dentro levantaram-se e vieram todos para as janelas que estavam voltadas para o assentamento, e ficaram observando o Sepé Tiaraju, a barraquinha, e a bandeira do MST tremulando nessa barraca. Cabe perguntar o que passava 
pela cabeça desses trabalhadores bóias-frias, ao verem outros trabalhadores rurais que eram sem-terra, ou seja, estavam submetidos às mesmas condições de pauperização e exclusão a que estão submetidos os bóias-frias, e hoje tem a sua terra, vivem dela, e não tem que se submeter à mesma situação de trabalho degradante que aqueles trabalhadores encaram diuturnamente.

Assim, na luta simbólica, o assentamento Sepé Tiaraju tem uma posição estratégica para todos os envolvidos, e até por isso sofre pressões de todos os lados.

Por parte dos usineiros, essa pressão se efetiva através de ofertas "tentadoras" para os assentados permitirem que se plante cana em seus lotes, cujas áreas são minúsculas se comparadas às áreas as quais esses usineiros têm acesso, não representando assim nenhuma vantagem econômica substancial para eles, mas tendo uma função simbólica de desacreditar a reforma agrária e um dos seus principais argumentos, que é a produção de alimentos em uma terra que antes produzia em forma de monocultura. Segundo contam os assentados e a liderança local do MST,

“[...] na nossa região, cê vê, a cana avança, nós temos que garantir uma série de coisas, nós temos um acordo de conduta aqui dentro com o Ministério Público, nós temos o assédio das usinas que querem plantar cana no nosso lote, que oferecem um monte de coisa, então, cê vê, a gente tem que continuar naquela resistência.” (Sr. Marco, entrevista).

Se há pressão por parte dos usineiros, há também uma pressão por parte do governo federal, através do INCRA, que quer mostrar que o modelo idealizado pela atual superintendência estadual dá certo. Cabe pontuar que no caso do Estado de São Paulo, esse 
modelo tem uma vantagem adicional para o poder público, que é o de poder colocar um número maior de famílias em uma terra que já está escassa e que tem um custo grande, aumentando assim os números da reforma agrária em uma região onde ela está cada vez mais difícil de ser realizada sem mexer efetivamente na estrutura fundiária, em função da defasagem dos índices de produtividade para cálculo com fins de desapropriação.

Conforme demonstram vários estudiosos da área, a política pública atual não pode ser chamada de reforma agrária, mas se trata de uma política de assentamento em regiões onde há conflito social, e utilizando terras do estoque público, ou seja, terras devolutas, terras de órgãos ou empresas públicas (como a FEPASA, Fundação ITESP, etc.) ou perdidas em dívida para o Estado. No caso do Estado de São Paulo, este estoque de terras está praticamente esgotado, e atingir a meta de números de famílias assentadas é difícil sem a desapropriação de terras.

O Sepé Tiaraju também é estratégico para o MST, que quer mostrar tanto que a reforma agrária dá certo quanto que o Modelo Comuna da Terra, que combina formas de trabalho familiar com formas coletivas, é o mais avançado modelo de assentamento já pensado no Brasil:

"Hoje o projeto nosso de assentamento aqui é dos mais avançados do Brasil, ... do Brasil! Nós somos um projeto... PDS... projeto de desenvolvimento sustentável, esse assentamento aqui. No Estado de São Paulo não existe. Começô a implantar no Estado de São Paulo a partir daqui, a partir daqui!" (Sr. Vitor, entrevista). 
Além disso, o Sepé Tiaraju tem também a responsabilidade de ser o primeiro assentamento na região de Ribeirão Preto, assumindo, para o Movimento, uma posição chave no avanço da "massificação" da luta num tradicional espaço do agronegócio no país, agronegócio esse que é gerador de pobreza e exclusão, bem como destruidor da biodiversidade da região.

Outro ponto a ser destacado é o impacto do Sepé Tiaraju nas relações políticas locais. A partir do momento em que foi homologado o assentamento, e que os assentados passaram a ter um endereço fixo e transferiram seus títulos de eleitor para a cidade de Serra Azul, o assentamento passou a ser frequentado por alguns políticos do município - alguns vereadores e o prefeito.

Além disso, a presença de um assentamento na municipalidade questiona inclusive os lugares sociais e as pequenas relações de poder já cristalizadas, como a relação professor/aluno, atendente do posto de saúde/população, gerente do banco/cliente, entre outras. O exemplo abaixo nos mostra uma situação onde as professoras tiveram receio de chamar a atenção dos alunos, porque estes eram Sem-terra, também tiveram receio de utilizar como expediente a famosa "reunião de pais", onde se expõem o comportamento inadequado de uma criança de forma pública, em geral envergonhando os pais.

[...] as professoras pediram pra marcar [a reunião] lá porque tem medo dos sem-terras irem à escola, e que elas também tem medo de chamar a atenção das crianças porque as crianças teriam dito que se elas [professoras] reclamassem, elas [crianças] iam ocupar a escola, porque elas eram Sem-terra (Diário de Campo, p.138; 09/05/2007). 
Um outro ponto é a inserção desses assentados no mercado consumidor regional. Além de produtores e fornecedores, como já falamos anteriormente, eles se inseriram também como consumidores na cadeia produtiva, dinamizando o comércio local. Os assentados adquirem os produtos em supermercados locais, lojas de roupas, de móveis, de eletrodomésticos e lojas de produtos agropecuários. Não é do escopo dessa pesquisa avaliar essa inserção, mas durante o trabalho de campo, pode-se perceber os assentados fazendo, de forma intensa, compras não só de bens pessoais e de consumo, mas de produtos agrícolas, bem como comerciantes se deslocando para o assentamento a fim de oferecer seus produtos aos assentados.

Quanto ao perfil dos assentados, um estudo realizado por Scopinho et. al (2007), revela que a maioria da população é adulta, e o tamanho das famílias varia entre duas a cinco pessoas, sendo grande o número de pessoas sozinhas, que perderam seus vínculos em virtude da migração. Efetivamente, é bastante presente na história de vida relatada pelos assentados a questão da migração, em especial em busca de trabalho e/ou de melhores condições de vida, como nos conta Geraldo:

Conheceu o Movimento quando morava em Brasília, um amigo de trabalho convidou-o para conhecer um acampamento. Depois disso, ele migrou bastante à procura de empregos eventuais. Foi para o Paraná, num trabalho eventual, e ali também teve contato com o MST. Depois foi para Campinas, onde andou pela região (Sumaré, Americana) à procura de emprego. Ali estava ruim de emprego, foi para outra cidade (em Minas) e arrumou um trabalho em um parque de diversões. [...] veio pra Ribeirão 
procurar alguma coisa. O dinheiro acabou e ele foi para o CETREM ${ }^{10}$, e um dia viu na televisão que o MST tinha montado um acampamento na Via Norte. [...] Foram recebidos pelo André [hoje assentado, tem cargo na direção regional no MST], que fez um monte de perguntas, se eles bebiam, se eram gente de paz, etc... O André os autorizou a montarem o barraco lá (Diário de Campo, p. 97, 30/01/2007).

Também é grande o número de pessoas sozinhas, como titulares de lote, em especial indivíduos do sexo masculino. É curioso notar que quando foi a mulher quem decidiu vir para o acampamento, a família como um todo se tornou acampada, incluindo aí o marido. Como exemplo, podemos citar o caso do Sr. Flávio e da Dona Graça, assentados que se auto-intitulam militantes do MST:

Um colega do Sr. Flávio disse que podiam entrar para o MST, e pegar terra. Um dia ele chegou e disse: vai ser amanhã a ocupação. Sr. Flávio resolveu ir. Largou o emprego, que era terceirizado, precário. Dona Graça disse que dava vontade de chorar quando ela chegou no acampamento. Ela resolveu voltar por causa da menina que ficou doente, então eles saíram do acampamento e voltaram para Sorocaba. (...) Depois, quem resolveu voltar a acampar foi a Dona Graça, e aí eles não saíram mais da luta, até serem assentados (Diário de Campo, p. 66; 11/01/2007).

Quando o marido entrou para a luta, sem a concordância da mulher, o vínculo familiar acabou se rompendo, e o homem foi assentado sozinho, o que acarreta muita

\footnotetext{
${ }^{10}$ CETREM - Centro de Triagem e Referência ao Migrante, funciona como um abrigo para migrantes.
} 
solidão e desistência, segundo os próprios assentados. Também é bastante grande o número de homens solteiros, que nunca foram casados. A grande quantidade de homens solteiros e os problemas sociais daí decorrentes, como alcoolismo, têm preocupado bastante os assentados em geral, e a liderança do MST mais especificamente. Segundo Dona Ana,

[...] vários desistem, e que fazia uns 20 dias que tinha desistido um ali em frente. Contou que há muitos que estão sozinhos, muitos estão alcoólatras, sozinhos não conseguem produzir, não tem uma TV, comem sozinhos, vão para a lavoura sozinhos, vão dormir sozinhos, e acabam desistindo [do assentamento]. (Diário de Campo, p. 43; 13/11/2006).

Um outro aspecto a ser observado no perfil dos assentados no Sepé Tiaraju é sua origem urbana. Boa parte deles revela não ter sido trabalhador rural, mas sim trabalhador urbano de baixa especialização, desempregado ou sem emprego fixo. Alguns trabalharam eventualmente como rurais, e outros contam que a família tinha sido de agricultores, mas que se lembravam de terem vivido na "roça" somente quando eram crianças, tendo se mudado pra cidade antes de se tornarem adultos.

Assim, um elemento novo e que precisa ser pontuado é que esse trabalhador que está no assentamento hoje, construindo a identidade de Sem-terra, e, portanto, de trabalhador rural assentado, não é um trabalhador do meio rural, mas um indivíduo oriundo do meio urbano.

Na formação da população assentada no Sepé Tiaraju, pode-se perceber um movimento inverso à tendência histórica das populações brasileiras: a migração da área rural para a urbana, conhecido como êxodo rural, que se iniciou nos anos cinquenta, 
acentuou-se entre os anos sessenta a oitenta, e que continua até hoje (CAMARANO; ABRAMOVAY, 1998), é invertida nesse caso específico, com a migração de indivíduos da área urbana para a rural. Esse, aliás, é um movimento cada vez mais percebido em assentamentos ligados ao MST, em especial em zonas altamente urbanizadas como é o caso do Estado de São Paulo.

Com as promessas de desenvolvimento, educação, saúde e pleno emprego não cumpridas pela urbanização, parte da população que migrou das zonas rurais para as urbanas, passa a considerar, de forma inclusive romantizada, a vida na "roça", pensando na possibilidade de voltar para esta, principalmente ao imaginar uma situação onde sua sobrevivência não estaria ameaçada, tendo-se em consideração que a situação de desemprego e de miserabilidade na cidade ameaça inclusive a sobrevivência física dessas pessoas.

Inicialmente, pode-se considerar que certos aspectos das críticas de Adorno ao rural - de que é mais barbarizado por não ter tido acesso aos benefícios do esclarecimento, tendo em vista que esse não chegou ao campo da mesma forma que chegou à cidade, não podem se aplicar no presente caso, tendo em vista que esses assentados tiveram uma trajetória inversa, vieram da cidade para o campo, tendo tido contato com a mesma educação e com os mesmos bens e serviços que são ofertados às populações pobres das grandes cidades. Se os benefícios do Esclarecimento aos quais os assentados tiveram acesso foram parcos, bem como a formação que tiveram na cidade se caracteriza com semi-formação, esta em nada se diferenciou da semi-formação a que todos estão submetidos nesta sociedade. Na verdade, a participação no MST, como vimos anteriormente, permitiu uma quebra nessa semiformação, proporcionando uma oportunidade de experiência verdadeira, com a verdadeira formação que isso acarreta. 
Além disso, pontuamos que a análise feita por Adorno, no caso dos camponeses alemães, no qual a indústria cultural no campo teria substituído de forma imediata a tradição, pois a autonomia e a consciência não tiveram oportunidade de se formar; não pode se aplicar integralmente no presente caso, tendo em visto que os assentados participaram de um movimento social de luta pela terra, que proporcionou uma oportunidade de formação da consciência de forma autônoma, processo esse durante o qual inclusive se questionava o papel da indústria cultural na homogeneização e na submissão dos indivíduos.

Há que se pontuar que, em função de sua origem urbana, o padrão de consumo dos assentados é eminentemente urbano. Vários assentados, assim que conseguiram se capitalizar minimamente, adquiriram carro, moto, televisão, celular, câmara digital, entre outros. Os desejos de consumo também são bastante influenciados pelo padrão de consumo urbano, e vários manifestam a intenção de comprar computador, ter acesso à internet no assentamento, ter carro, moto, máquina de lavar, entre outros. Da mesma forma como é pontuado por Adorno, no caso dos camponeses alemães de sua época, a indústria cultural se faz bastante presente no assentamento, como discutiremos posteriormente, o que influencia significativamente o desejo de consumo desses assentados.

Com relação à organização política do assentamento, a Agro-Sepé é a figura jurídica que representa a entidade associativa dos oitenta assentados, chamada de associação-mãe. Segundo os parâmetros de um PDS, é preconizada a existência de uma entidade organizativa para legalizar a posse das terras. A Agro-Sepé tem sua diretoria composta por um Presidente, um vice-presidente, tesoureiro, mais os dois coordenadores de cada um dos núcleos, em geral um homem e uma mulher, que são os diretores das associações-filhas. Cada núcleo corresponde a uma "associação-filha", que pode se subdividir em outras “associações-netas”. 
Participam das reuniões semanais da direção da Agro-Sepé, além de seus dirigentes e os coordenadores dos núcleos, os coletivos do assentamento, bem como o assentado que tiver interesse em participar, pois as reuniões são abertas. A diretoria da Agro-Sepé coincide com a Coordenação Geral do assentamento. Nas reuniões da AgroSepé/Coordenação Geral do assentamento acontecem discussões sobre os vários assuntos do cotidiano do assentamento, que vão desde a organização social, passando pela produção, até chegar a relações interpessoais.

Segue abaixo uma tabela com os principais conteúdos discutidos em 12 reuniões de coordenação dos núcleos e do assentamento, das quais nós participamos, bem como a frequência com que esses assuntos foram abordados:

Tabela 2: Conteúdos das reuniões dos núcleos/coordenação.

\begin{tabular}{|l|l|c|}
\hline Tema & Conteúdo & Freq. \\
\hline \multirow{4}{*}{ Questões administrativas } & Mudança de coordenador & 2 \\
\cline { 2 - 3 } & Necessidade das pessoas participarem mais das reuniões & 2 \\
\hline \multirow{5}{*}{ Produção } & & \\
\hline & Recursos & 3 \\
\cline { 2 - 3 } & Grupos de afinidade & 2 \\
\cline { 2 - 3 } & Divisão de área & 2 \\
\cline { 2 - 3 } & Comercialização & 4 \\
\cline { 2 - 3 } & Projetos de plantio/orientações técnicas & 2 \\
\cline { 2 - 3 } & Registro da Agro-Sepé & 1 \\
\hline \multirow{5}{*}{ Questões de infra-estrutura } & & \\
\hline & Construção de casas & 2 \\
\cline { 2 - 3 } & Água & 2 \\
\cline { 2 - 3 } & Luz & 2 \\
\cline { 2 - 3 } & Presídio invadindo área do assentamento & 1 \\
\hline & & 4 \\
\hline & Desentendimentos & 2 \\
\cline { 2 - 3 } & Brigas (agressão) & 1 \\
\cline { 2 - 3 } & Arrendamento & 1 \\
\cline { 2 - 3 } & Utilização do poço & \\
\cline { 2 - 3 } & Assentado "passando por cima" da coordenação & \\
\hline & & \\
\hline Relação com o MST & Ausência/ presença do movimento social & \\
\hline & & \\
\hline
\end{tabular}




\begin{tabular}{|l|l|c|}
\hline \multirow{4}{*}{ Relação com o Estado } & Assistência técnica & 2 \\
\cline { 2 - 3 } & Políticas públicas & 2 \\
\cline { 2 - 3 } & Recursos & 6 \\
\cline { 2 - 3 } & Relações pessoais com os técnicos & 4 \\
\cline { 2 - 3 } & Documento da terra & 1 \\
\hline \multirow{5}{*}{ Outros } & & 1 \\
\hline & Atividade religiosa & 1 \\
\cline { 2 - 3 } & Atividade festiva & 1 \\
\cline { 2 - 3 } & Relação com as professoras & 2 \\
\cline { 2 - 3 } & Saúde - marcar consultas & \\
\hline
\end{tabular}

Fonte: Diário de Campo.

Foram vários os momentos em que se travaram bonitas discussões e construções coletivas nesse espaço de reunião. Um deles foi a discussão de como fariam com a água para as brigadas (mutirões) poderem construir as casas. A discussão durou cerca de três horas ininterruptas, até de forma confusa em alguns momentos, e ao final surgiu uma proposta de distribuição de água que contemplou as contribuições de todos os presentes:

Aí os assentados começaram a discutir o problema da água para construir, um perguntou ao outro quanto gastava, se 500 litros, se mais, se menos. Ivan falou que tinha ainda a questão das três contas de luz do poço. [...] Alguém lembrou que a água do poço até dar o valor mínimo podia ser usada para encher o caminhão pipa. Ivan contou então da reunião com o prefeito, Sr. Arthur contou que ele dá parte do combustível para o caminhão-pipa rodar, e que o INCRA, que cedeu o caminhão, disse que ia recolher, porque ele tava parado lá, estragando. Começaram a discutir onde conseguir mais diesel, pois o Sr. Arthur colocou a proposta de que o caminhão circule pelo assentamento distribuindo água. Passaram à discussão se era água para beber ou para construir [...] Passaram a discutir quantos litros cabiam no caminhão, quanto de diesel ele consumia, 
quantas casas seriam construídas por vez, quanto de água cada casa consumiria, como medir a quantidade de água a ser deixada em cada lugar, quanto cada família sem construção consome, onde colocar essa água, etc... [...] Por fim, decidiram que seriam dados 1000 litros para cada brigada, onde estivesse construindo, e 200 litros por família, independente do número de pessoas, uma vez por semana. Na semana seguinte, o volume seria completado, assim a família que gastasse mais por ter mais membros receberia mais (completaria um volume maior), e a família com menos membros, menos água (Diário de Campo, p. 136/137; 09/05/2007).

Se considerarmos o tempo despendido com cada um dos temas nas reuniões de núcleo e de coordenação, os assuntos que mais ocuparam a atenção dos assentados em suas reuniões de organização foram o de relações com agências presentes no assentamento, como o INCRA e o MST, a relação entre os assentados, as questões de produção e as administrativas.

Tabela 3: assuntos que mais ocuparam o tempo de discussão dos assentados nas reuniões de coordenação de núcleos e do assentamento.

\begin{tabular}{|l|c|l|}
\hline Tema & Freq. & \multicolumn{1}{|l|}{} \\
\hline Relação com o INCRA & 4 & $\begin{array}{l}\text { Assistência técnica e liberação dos recursos; } \\
\text { PRONAF; fomento; dinheiro do recibo de pedreiro das } \\
\text { casas. }\end{array}$ \\
\hline Relação com a liderança do MST & 3 & Ausência e demanda de presença. \\
\hline Infra-estrutura & 2 & $\begin{array}{l}\text { Água; casas (HABIS- Grupo de Pesquisa em } \\
\text { Habitação e Sustentabilidade da EESC-USP e da FEB- } \\
\text { UNESP) }\end{array}$ \\
\hline Relações entre assentados & 3 & Rompimento no núcleo; divergências internas. \\
\hline Administrativo & 2 & Exclusão de arrendante; troca de coordenação \\
\hline Produção & 4 & $\begin{array}{l}\text { Projetos de produção; CONAB; parceria para venda da } \\
\text { palha de milho; orientação técnica -adubo orgânico. }\end{array}$ \\
\hline
\end{tabular}

Fonte: Diário de Campo. 
O que se pode perceber, quase ao final do trabalho de campo, é que houve um esvaziamento gradual das reuniões, que passaram a acontecer com pouca gente, ou acontecendo de quinze em quinze dias e, em alguns núcleos, tendo deixado completamente de acontecer, não havendo mais coordenadores eleitos (Diário de Campo, p. 107).

\footnotetext{
“As reuniões que tinham antes, reunião de coordenação, dos núcleo, o Movimento tava sempre junto, participando, orientando... acabou. [Não tá tendo mais reunião de núcleo?] Não tem. Esses dias o Augusto (técnico do INCRA) veio aí, fez reunião, falô que tinha que tirá coordenadores, isso foi a um mês mais ou menos, falô que eles viriam de quinze em quinze dias, que a Helena e o Mateus que é os outros técnicos, gostariam de tar participando também... tudo mentira, não teve reunião de núcleo, não teve reunião de coordenação, não teve reunião de nada." (Sra. Simone, entrevista).
}

Boa parte dos assentados já não quer assumir o papel de coordenador dos núcleos, por considerá-lo como um dispêndio de tempo ou, como um deles se referiu, uma "fria". Em uma eleição de coordenador em um dos núcleos, a qual tive a oportunidade de assistir, ninguém queria assumir a função. No fim, duas pessoas foram selecionadas: o Sr. Henrique, que aceitou o cargo com a condição de que a partir daquele momento o mandato seria de 90 dias (e não mais de 6 meses, como era antes), "pra não ficar pesado pra ninguém"; e uma senhora que não queria mas teve que assumir por causa da regra de que os 
coordenadores devem ser um homem e uma mulher, e não poderia repetir coordenador até todos terem sido. (Diário de Campo, p. 79, 11/01/2007).

A máxima de que "tempo é dinheiro", adequada á forma de organização do tempo dos indivíduos no sistema capitalista, onde até o ócio é instrumentalizado e organizado segundo os interesses de produção e de lucro, através dos mecanismos da indústria cultural, também passa a influir na distribuição e na organização do tempo do assentado, com a entrada da lógica da mercadoria no assentamento. A lenta e crescente adaptação ao sistema capitalista contribui para o esvaziamento dos espaços públicos, justamente em função do tempo dos assentados passar a ser medido segundo o princípio do equivalente.

Nesse sentido, participar de reuniões, de discussões, é "perda de tempo", ou seja, dispêndio de um tempo que poderia estar sendo investido na produção de mercadorias agrícolas e na comercialização dessas mercadorias. Da mesma forma, assumir o papel de coordenador de núcleo ou do assentamento implica em dispor de seu tempo de produtor rural para uma atividade cujo retorno não pode ser objetivamente medido, pelo menos não de forma imediata.

Com isso, os espaços públicos de discussão e de construção coletiva estão ficando esvaziados, com sérios riscos de deixarem de existir.

Segundo Dona Ana, vários coletivos funcionavam no Sepé-Tiaraju na época do acampamento, como o coletivo de produção, de cultura, de saúde, de educação, de disciplina. Nas reuniões da direção do assentamento, atualmente estão representados os coletivos de saúde e educação. Da mesma forma, esses foram os dois coletivos que funcionaram durante essa pesquisa, o de saúde mais vezes, com uma pessoa só; o de educação, menos vezes, mas com duas a três pessoas. 
No caso do coletivo de saúde, este é bastante ativo, mas continua funcionando com uma pessoa só, ligada à liderança do MST. Essa senhora virou referência para todos os casos de saúde do assentamento, e dispende várias de suas horas de trabalho para cuidar dos outros, deixando seu lote e sua produção agrícola em segundo plano por isso (Diário de Campo, p. 121).

\subsection{Atores presentes no assentamento}

Além da presença do MST, que é bastante forte no assentamento, há ainda várias agências públicas e religiosas que atuam no assentamento. Entre as primeiras, podemos citar universidades e entidades ligadas a estas, empresas públicas de pesquisa (EMBRAPA - Empresa Brasileira de Pesquisa Agropecuária), agências de ATER (Assistência Técnica e Extensão Rural), Ministério Público e instâncias da municipalidade.

Entre as entidades públicas, uma das mais presentes no assentamento, através de seus técnicos e pesquisadores, é a EMBRAPA, por meio de sua unidade Meio Ambiente. Esses profissionais realizam cursos chamados de "dia de campo", nos quais o pesquisador realiza uma atividade teórica e prática em alguma área do assentamento (área comum ou lote de assentado), e para a qual são convidados a participar os assentados que tiverem interesse, sendo emitido um certificado de participação ao final. Além disso, a EMBRAPAMeio Ambiente também realiza atividades de agrofloresta fora do assentamento, criando possibilidade de participação para os assentados que tiverem o desejo de participar. Em geral, essas atividades consistem em visitas monitoradas a produtores que trabalham em regime de agrofloresta, ou participação em eventos e congressos da área. 
Cabe pontuar que esse movimento tem se invertido, ou seja, em vez de os assentados saírem para participar de visitas monitoradas nos sítios e fazendas de produtores agroecológicos, tem crescido significativamente o número de visitas monitoradas de outros produtores ao assentamento Sepé Tiaraju, realizadas pela EMBRAPA, visando difundir o modelo agroecológico de produção. Tal inversão se deve ao fato de que vários assentados têm produzido segundo o modelo agroecológico, inventando novas formas de produção e consorciamento de plantas.

Outra entidade ligada a centro de pesquisa e presente no assentamento é o HABIS, Grupo de Pesquisa em Habitação e Sustentabilidade, formado por integrantes ligados à Escola de Engenharia de São Carlos (USP) e à Faculdade de Engenharia de Bauru (UNESP). Esse grupo é responsável pelo projeto de construção das casas dos assentados, realizada com recursos da Caixa Econômica Federal e do INCRA. Os estudantes de arquitetura e engenharia ligados a este grupo, orientados por professores ligados às duas universidades, realizaram os projetos e acompanham as obras de construção das casas, gerindo os recursos e os pagamentos das aquisições de material de construção e da mão de obra (pedreiros).

Outro importante ator no assentamento é o governo federal, principalmente representado pelo INCRA (Instituto Nacional de Colonização e Reforma Agrária), cuja atuação, por sua importância, será discutida em um tópico separado.

Já com relação ao governo estadual, a presença é mínima, e em geral, negativa. Ao colocar a terra para venda em leilão, o governo estadual reservou uma parte considerável da fazenda para a construção de um presídio, que foi rapidamente levantado e entrou em funcionamento. Essa atuação do governo estadual é reveladora de sua forma de lidar com a questão social, uma vez que vários assentamentos do Estado de São Paulo têm que conviver 
com presídios: a reforma agrária é afim às questões de polícia. A presença do presídio praticamente dentro do assentamento causa vários problemas, sendo que um deles é a disputa por área, tendo-se em vista que o presídio constantemente invade a área do assentamento, ameaçando fazer construções ou alegando área de segurança. Alguns problemas causados pelo presídio eram considerados anteriormente como típicos da área urbana: a ocorrência de rebeliões e a presença de elementos de grupos criminosos na área do assentamento, ameaçando a tranquilidade dos assentados.

Na verdade, hoje existem setenta e nove lotes ocupados, e um deles está com uma família que os assentados e os agentes estatais nomeiam de "invasores". Esta família seria, segundo técnicos e assentados, ligada ao $\mathrm{PCC}^{11}$, e sua matriarca teria dois filhos presos que pertencem a essa organização, em outros presídios. Essa senhora teria ameaçado de morte qualquer assentado ou agente que ousassem tentar expulsá-la do assentamento. É interessante notar que nem liderança, nem técnicos estatais, nem assentados chegam perto desse lote. Correu um boato, dentro do assentamento e entre os técnicos, de que o INCRA em São Paulo havia determinado a reintegração de posse desse lote, e os técnicos comentavam entre si que pediriam demissão, mas não realizariam esse serviço (Diário de Campo, p. 116).

Por outro lado, aos finais de semana, em dias de visitas, alguns assentados aproveitam a presença das mulheres dos presos - que acampam de um dia para o outro na porta do presídio para poderem entrar bem cedo, a fim de comerciarem e prestarem serviços, seja alugando um espaço de camping no assentamento, seja alugando banheiro,

\footnotetext{
${ }^{11}$ Primeiro Comando da Capital, organização que age nos presídios do Estado de São Paulo, aglutinando, de forma organizada, aqueles que são denominados de criminosos, estejam eles presos ou não.
} 
seja vendendo refeições (jantar, café da manhã e almoço), seja vendendo os produtos agrícolas do assentamento.

As igrejas também se fazem presentes no Sepé. A proximidade da liderança do MST é maior com a Igreja Católica, que apoiou o assentamento, através de sua ala progressista, desde a época do acampamento.

Assim, houve o apoio de um padre da diocese de Ribeirão Preto desde a época das ocupações, e os assentados, mesmo os evangélicos, falam com carinho desse padre, contando que quando eles iam "entrar" na fazenda ou quando ia ocorrer alguma reintegração de posse, o padre estava lá com eles, pra "apanhar junto". Há que se pontuar que o líder evangélico mais proeminente do assentamento trabalha junto com esse padre, e eles têm uma proximidade pessoal e afetiva muito grande.

Atualmente, duas freiras franciscanas vivem no assentamento, em uma pequena casinha levantada na área comum, e fazem um trabalho de evangelismo. Os assentados aquiesceram com a entrada das irmãs, bem como com a realização de outros trabalhos religiosos (semana de atividades dos Canocianos) em função da proximidade com esse padre, mas a princípio, boa parte deles era contra:

Durante o almoço, me contou que duas freiras franciscanas iam vir passar um ano no assentamento, que ia ser construída uma casinha no sitinho. Falou que não sabia se isso era certo, porque a maioria ali era crente (Diário de Campo, p. 112; 15/03/2007).

A resistência à entrada dos religiosos se devia mais a uma questão de sobrevivência, em função da fome, pois não tinham alimentos suficientes para todo mundo 
e teriam que dividir com os religiosos, especialmente com os canocianos, que fariam uma semana de evangelismo no assentamento, com cerca de vinte e cinco religiosos simultaneamente:

[...] a questão da refeição foi um pouco mais discutida, alguns assentados fizeram referência a ser um pouco puxado, mas resolveram que cada grupo de seis ou sete que estavam no núcleo deveriam almoçar por ali. (Diário de Campo, p. 157, 27/06/2007).

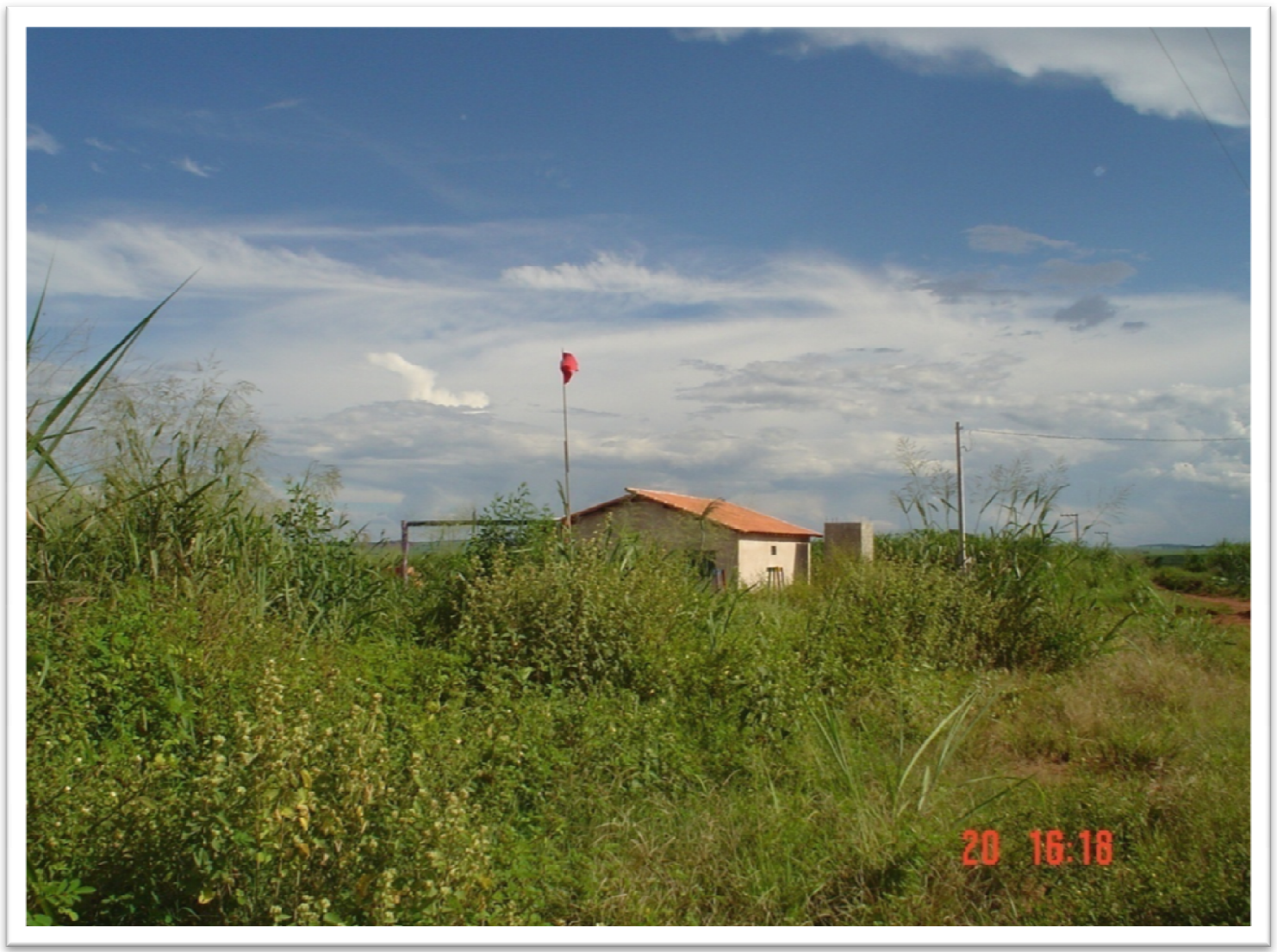

Figura 4: residência das freiras na área comum. 
Acabaram por aceitar as irmãs, como dissemos, por deferência ao padre, que é muito querido no Sepé Tiaraju. Posteriormente, essas irmãs foram completamente aceitas e absorvidas pelo assentamento, passando a ser referência e a terem um papel importante na comunidade, conforme pontua o próprio líder evangélico do assentamento:

“[o positivo no assentamento] é isso que eu falo pra você, o apoio do governo, da sociedade e a resistência nossa. A sociedade que eu falei pra você, o povo da cidade, é a faculdade, é a Igreja Católica, o apoio muito grande da igreja evangélica. Hoje nós temos um número muito grande de assentados evangélicos dentro dos assentamentos, aqui dentro mesmo, tanto tem o salão que nós congrega aqui, que tem uma média de trinta membros, como a gente tá construindo uma igreja pra mais de duzentas pessoas aqui no assentamento, uma igreja evangélica. Nós já tem hoje aqui também as irmãs, que é uma benção pra nóis aqui, as freiras, que já construiu a casa delas aqui dentro, que nós dá um apoio muito grande.” (Sr. Arthur, entrevista).

Parte significativa dos assentados é evangélica, sendo que em um dos núcleos, o número chega a quase $100 \%$, sendo bastante alto nos outros núcleos também. No entanto, não há trabalho institucional de igreja evangélica dentro do assentamento, apenas reuniões de oração e de estudos da Bíblia em uma construção cedida na casa de uma adepta. Essas reuniões são dirigidas e realizadas pelos próprios assentados, isto é, sem a presença de ministro religioso de fora do assentamento. 
As atividades realizadas no assentamento, além das de produção, são quase que exclusivamente as religiosas, excetuando-se alguns eventos culturais, como as festas juninas. O "lazer" do assentado, então, é frequentar alguma atividade religiosa.

Por outro lado, diferentemente do que pontuam alguns estudiosos, aparentemente não há tensionamentos decorrentes da presença da Igreja Católica dentro do assentamento, no sentido desta tentar impor um padrão de comportamento ou disputar espaço de liderança com o movimento social (CAUME, 2002). Do que se pode perceber no Sepé Tiaraju, a igreja assumiu uma postura bastante coadjuvante na organização do assentamento, apoiando o MST e os assentados, mas não disputando a primazia ou modelos de organização do assentamento com o Movimento. Na verdade, as freiras e diáconos católicos que frequentam o assentamento atualmente, se ocupam de atividades exclusivamente ligadas à vida espiritual e religiosa, como aconselhamentos, batismos, missas, etc., deixando as questões políticas exclusivamente com os assentados e com a liderança do Movimento.

Segundo a liderança local do MST, a tensão se dá na relação com os evangélicos, pois um dos líderes religiosos evangélicos disputaria a condução do assentamento com a liderança do MST. Cabe pontuar que esse líder religioso era da liderança do Movimento, no qual militou por cerca de quinze anos, tendo inclusive feito formação no MST e morado no Centro de Formação. Segundo esse assentado, ele entrou para o Movimento através dos trabalhos da CPT, estando no MST desde 1988.

No entanto, o que se pode perceber no dia-a-dia do assentamento, é que os desentendimentos e disputas que ocorrem entre assentados e liderança, que discutiremos posteriormente, não têm uma motivação propriamente religiosa, e nem sequer envolvem a questão religiosa, mas se trata de uma diferença de compreensão acerca da atuação da 
liderança local no assentamento, por parte dos assentados, e vice-versa, travestida de questão religiosa, tendo-se em vista que aquele que primeiro teve coragem de fazer críticas à atuação da liderança regional do MST no assentamento é religioso. Dos assentados com alguma atividade religiosa, sejam evangélicos ou católicos, parte continua ligado à liderança local do MST, parte está afastada, independente da filiação religiosa.

O assentamento está já bastante inserido nas relações locais, em especial nos dois municípios mais próximos, Serra Azul, onde ele está localizado, e Serrana. Há um deslocamento bastante grande também para a cidade de Ribeirão Preto, para serviços e atividades comerciais de maior complexidade.

Também há a presença de políticos locais, como vereadores, frequentando o assentamento. Há a presença bastante grande de um vereador, eleito pelo PDT, dentro do assentamento: esse vereador comparece em vários eventos, está sempre recebendo os assentados, atendendo suas solicitações de forma pessoal (envio de ambulância, pedido de reunião com o prefeito), e os assentados sempre falam nele quando tem que resolver algum problema no município de Serra Azul. O assentamento é entendido por esse vereador como sendo uma de suas bases eleitorais. Assim aparentemente entendem também os outros políticos do município, por exemplo, o prefeito, pois sempre que precisa ser representado em algum evento no assentamento, designa esse vereador para comparecer.

Se os assentados já estão inseridos nas relações políticas locais, por outro lado, há ainda uma hostilidade muito grande de uma parte da sociedade, que já parte de um preconceito sobre o assentado e o Sem-terra. Exemplos desse preconceito, bem como da agressão simbólica e real a que os assentados estão submetidos são o das professoras do município de Serra Azul que têm medo e não querem chamar os pais na escola porque eles são Sem-terra, ou daqueles que passam na pista ofendendo os assentados: 
Durante o tempo que passei lá, mais ou menos umas quatro horas, em que os assentados estavam trabalhando pesado, uns dois ou três carros passaram gritando 'Seus vagabundos, essa moleza vai acabar', numa referência à possível eleição presidencial de um candidato contrário aos Sem-terra (Diário de Campo, p. 34; 20/10/2006).

Assim nos conta Sr. Arthur sobre uma reunião de pais ocorrida dentro do assentamento, realizada por um vereador de Serra Azul:

\footnotetext{
Quando Sr. Arthur chegou ali, ficou sabendo que era uma reunião para discutir o mau comportamento das crianças na escola e no ônibus, marcada pelo vereador Zézinho, a pedido das professoras. (...) as professoras pediram pra marcar lá porque tem medo dos Sem-terras irem na escola, e que elas também tem medo de chamar a atenção das crianças porque as crianças teriam dito que se elas (professoras) reclamassem, elas (crianças) iam ocupar a escola, porque elas eram Sem-terra (Diário de Campo, p.138; 09/05/2007).
}

Outro exemplo de preconceito e da hostilidade de segmentos da sociedade para com os Sem-terra é a representação que a mídia local faz deles. Quando da realização de um protesto na pista por estarem vivendo há sete anos sem água, e após passarem toda uma manhã bloqueando e liberando a pista em baixo de um sol escaldante, o que apareceu na Folha Ribeirão foi uma foto de uma senhora sentada no cavalete de bloqueio, com os dizeres "Sem-terra bloqueia veiculo ontem na rodovia Abrão Assed (Ribeirão a Serrana), 
para exigir melhorias em assentamentos" (vide anexo 3), dando a impressão de "baderna" e "folga".

$\mathrm{Na}$ fala dos assentados é recorrente o fato da mídia apresentar uma visão negativa deles. Muitos contam que antes de entrar para o MST, "acreditavam no que a TV dizia dos Sem-terra", tendo vindo para a ocupação somente porque não tinham outro recurso, ou porque alguém que conheciam tinha vindo e apresentava uma visão diferente:

\footnotetext{
"Hoje nós temos uma propaganda muito grande na cidade, falando do álcool, do etanol, e tá faltando comida no mundo (...). Quando é Semterra que faz alguma coisa, sai na televisão: 'nossa, que horror, Semterra!', vem um comentarista, gente que tá lá preparado para defender o capital mesmo, mete o pau no movimento social porque nós não respeitamos a lei e tal; mas quando é fazendeiro, os caras que tão desmatando a Amazônia, tão desmatando e matando gente, mas como é fazendeiro tem só um comentariozinho assim de nada, não falam que são malandros... então são dois pesos e duas medidas. E isso joga com a cabeça de nós povo, que não temos uma formação, não somos bem educados, e as vezes defendemos até coisa errada..." (Sr. Marco, entrevista).
}

Vários assentados contam que demoraram a se juntarem ao Movimento dos Sem Terra porque tinham medo, pois viam na televisão que eles causavam confusão e que "matavam fazendeiro" (Sr. Geraldo, entrevista).

Outros assentados relatam que também eram mal-falados na cidade de Serra Azul, em função de terem ocupado a fazenda onde hoje é o assentamento, e que eram destratados 
pelas pessoas na cidade por causa disso. Alguns contam que hoje, quando entram com dinheiro na mão nos mesmos estabelecimentos comerciais onde eram destratados ou "que eram muito contra eles quando eles eram Sem-terra", são bem recebidos, comentando que “no capitalismo é assim” (Diário de Campo, p. 129, 09/05/2007). Os assentados pontuam que hoje as relações com a sociedade do entorno mudou, estando eles bastante inseridos na rede de vínculos sociais, políticos e econômicos da região. Apesar disso, os assentados ainda demonstram estarem preocupados em ser bem vistos nos municípios próximos ao assentamento.

Na verdade, os assentados dão grande importância à como são vistos pelos diversos segmentos com quem se relacionam, seja com os vários atores que passam pelo assentamento, seja com os moradores das cidades próximas. Abaixo, há um exemplo dessa preocupação, ocorrido em função da não liberação do dinheiro para pagar o comércio local, sendo que eles já haviam feitos compras após "autorização" verbal dos técnicos do INCRA:

\footnotetext{
Alguns assentados tinham ido ao banco para retirar o dinheiro do PRONAF, após já terem feito compras no comércio local, e o gerente do banco disse que não ia liberar o dinheiro, porque o técnico do INCRA disse para ele (gerente) que o dinheiro só podia ser liberado com a assinatura dele (técnico). Os assentados estavam bastante nervosos, reclamando que os credores já estavam cobrando, e que eles estavam ficando 'queimados' no comércio local. (Diário de Campo, p. 131, 09/05/2007).
} 
Existe uma valorização do modo como a sociedade os vê, e há um olhar voltado para o que a sociedade diz deles, para o que a sociedade pensa, para o que os "amigos" pensam, tanto por parte dos assentados, quanto por parte da liderança. Quando de minha participação em dois dos vários momentos tensos que acompanhei, alguns assentados se manifestaram da seguinte forma:

Vitor pediu para o Sr. Marco terminar a reunião, que aquilo não ia dar em nada. Alguém lá do fundo falou: ‘- Que feio, brigando na frente da visita', com referência á minha presença, ao que outro retrucou: '- É bom, que ela já vê a realidade.” (Diário de Campo, p. 86, 11/01/2007).

Dona Ana pediu a palavra, visivelmente constrangida, e disse que estavam tendo problemas sim, só que ela gostaria que isso não fosse falado na frente de visita. (Diário de Campo, p. 162, 27/06/2007).

No primeiro caso, estavam preocupados com a minha presença - era a primeira vez que eu presenciava um desentendimento público e coletivo no assentamento, e a segunda vez, com a presença de uma freira e um padre, que estavam iniciando um trabalho de evangelização no Sepé Tiaraju.

Com relação a isso, podemos pontuar que não é somente a liderança do MST, em seus documentos oficiais, que frisa a importância de se veicular uma imagem positiva do assentamento, de que este constitui uma nova comunidade, com regras e costumes diferenciados do entorno, como um território liberado que seria um vislumbre da nova sociedade que os setores progressistas da sociedade sonham em construir. Os próprios 
assentados também trabalham no sentido de reforçar essa imagem do assentamento como um espaço harmonioso, solidário e sem conflitos.

A presença de conflitos nas relações que se constroem dentro do assentamento não é entendida como algo inerente aos processos sociais dentro dessa sociedade capitalista, mas encarados como sinais de que aquela comunidade "não deu certo", ou seja, de que ali não existe solidariedade, ou de que há falta de consciência, ou que o potencial emancipador daquele assentamento se perdeu. Isso leva uma negação dos conflitos e contradições, ou ao menos uma tentativa de escamoteá-los, que aprofunda mais ainda o sentimento de falsidade e inadequação perante aquilo que eles “deveriam” ser.

Nesse sentido, podemos perceber que tanto a liderança quanto os assentados contribuem para a construção de uma visão idealizada acerca do assentamento e do assentado, trabalhando para veicular a imagem de um novo homem e de uma nova sociedade como já realizada. De certa forma, a preocupação de ambos contribui para reforçar a romantização do assentamento, muitas vezes assumida não só pelos militantes do movimento social, mas também pelos estudiosos do tema.

Em uma sociedade onde as aparências têm preponderância sobre o real, onde o falseamento da realidade cumpre um papel ideológico, ou seja, de naturalizar o já dado e contribuir com que a falsa experiência social não seja rompida, escamoteando o processo histórico e social que levou à criação daquela realidade, não é de se estranhar a preocupação dos assentados e da liderança com como o assentamento é visto.

A maior parte da sociedade somente enxerga os aspectos que são veiculados pela mídia porque, de todas as formas, é mais fácil absorver uma opinião que já vem pronta, do que parar para refletir sobre a reforma agrária, os sem-terra e as ocupações, uma vez que, por um lado, isso demandaria um esforço e uma capacidade há muito atrofiada nos 
indivíduos, que é o pensar de forma não estereotipada, e por outro lado, os indivíduos suspeitam que isso questionaria a própria adaptação deles a um sistema injusto. Os homens, nessa sociedade, esforçam-se por fechar os olhos e se apegarem a satisfações substitutivas que, em realidade, não satisfazem. Assim, a sociedade não quer ver o que é diferente dela, o que não se encaixa, bem como o que denuncia, na forma de ruptura, a absoluta falta de racionalidade do todo social (ADORNO, 1992).

A questão de como são vistos pela sociedade também é influenciada pela luta simbólica que atravessa a existência do assentamento. A própria possibilidade de existência de um assentamento de trabalhadores rurais aponta para a possibilidade de um modo de vida onde não haja "patrão", ou seja, onde cada indivíduo seja senhor de seu trabalho e de sua vida, onde ele possa viver com dignidade, onde minimamente o indivíduo possa atingir o principal objetivo da sociedade emancipada, ou seja, o assentamento pode se constituir em um espaço onde ninguém mais passa fome (ADORNO, 1992). A autonomia e a autodeterminação, se não ocorrem de fato, são fortemente sugeridas e se constituem enquanto possibilidades concretas, com a efetivação de um assentamento. A própria possibilidade de alternativa, em um mundo que faz alarde do progresso em um único sentido e direção, é contestadora e precisa ser abafada, seja pela eliminação, seja pela absorção no todo social.

A disputa por aparência se dá de forma injusta e desigual, pois a mídia e o poder político estão do lado daqueles a quem interessa veicular uma imagem negativa dos assentados, a fim de sufocar toda possibilidade de questionamento e de alternativa que eles representam. Isso insta os próprios assentados a trabalharem ativamente para serem aceitos pelo todo social, para terem uma boa imagem perante a sociedade, pois como sabemos, o 
risco de ser excluído mobiliza uma sensação de medo ante a possibilidade de aniquilação física e social.

Sendo na relação com o outro que se constitui a identidade, os assentados se relacionam, em seu dia-a-dia, em suas necessidades de cuidado com a saúde, com a educação de seus filhos, e nas relações de compra e venda, com as pessoas da cidade e com os agentes estatais que frequentam o assentamento, cuja opinião passa então a ser relevante para o indivíduo. Há que se observar que parte significativa dessas relações estão mediadas pelo princípio do equivalente e por uma racionalidade instrumental. As questões práticas da vida, todas elas contaminadas e estruturadas pelo princípio do lucro, contribuem para atrofiar o que poderia haver de humano e de isento de interesses nas relações entre os homens, e essa lógica acaba por se fazer reproduzir dentro do assentamento.

No caso da liderança, ao estarem envolvidos mais diretamente com a mobilização e com a luta, seu contato se dá majoritariamente com outros atores, o que implica que suas identidades se formam em uma relação mais antagônica e numa divisão mais marcada com elementos tipicamente pertencentes ao sistema capitalista. Esses indivíduos se importam mais significativamente, por exemplo, com o que pensam o Ministério Público ou com o que as instituições de pesquisa acadêmicas veiculam sobre sua imagem, por uma questão de estratégia de luta visando a transformação social, do que propriamente com o que pensam atores do cotidiano do assentamento, cuja opinião influenciam mais os assentados. 


\subsection{Aspectos culturais e sociais}

Um dos aspectos do modelo de assentamento organizado segundo os moldes Comuna da Terra é o de valorizar a proximidade à cidade, bem como aos seus serviços. Efetivamente, o assentamento Sepé fica na beira do asfalto, há serviço de ônibus "de linha" tanto para Serra Azul, quanto para Serrana e Ribeirão Preto. Os assentados frequentemente usam os serviços desses municípios, para questões de saúde, escola, previdência social, compra e venda de produtos e outros.

Se por um lado, estar perto da cidade traz vantagens, por outro, evidenciam as duras condições objetivas de existência as quais os assentados estão submetidos, como a falta de serviços sociais, a habitação ainda de forma precária, a ausência de serviços básicos, como a água (encanada ou de poço) e a precariedade de outros serviços, como energia elétrica.

A proximidade da cidade, aliada à experiência de vida anterior dos assentados, eminentemente urbana, faz com que eles sejam atraídos pelo modo de vida urbano. Lúcia, assentada ligada à liderança do MST, que antes estava envolvida com o Movimento dos Sem Teto,

conta que teve muita dificuldade de se adaptar, e que ainda tem, 'porque na cidade, nos 'sem-teto', você tem um monte de conforto que não tem no campo, por exemplo, uma água, uma luz elétrica, ainda que "gato", mas tem' (Diário de Campo, p. 70; 11/01/2007).

Conforme já pontuamos anteriormente, a influência do modo de vida urbano típico da sociedade capitalista se faz sentir também nas necessidades de consumo de parte dos assentados. Assim, com a instalação da energia elétrica no assentamento, a primeira 
aquisição feita por grande parte das famílias foi a de um aparelho de televisão. Da mesma forma, com a liberação dos recursos do PRONAF, os assentados queriam utilizar o dinheiro para cada um ter seu próprio trator e seus próprios implementos, e como o recurso não foi suficiente, compraram vários tratores, em grupos de quatro ou cinco assentados. Segundo um dos agrônomos que prestam assistência técnica para o assentamento, esse foi um consumo além do necessário, tendo em vista o tamanho do assentamento:

[...] compraram por conta própria, ao contrário da recomendação técnica, tratores e implementos desnecessários, que para o assentamento todo, um trator dava, e ainda ia ficar sem uso em uns dois anos, mas que não foi por falta de falar, os assentados quiseram comprar mesmo assim, ele acha que é porque eles querem ter para eles. Disse que é igual rico: quando sai o crédito, a primeira coisa que compram é camionete (Diário de Campo, p. $169 ; 27 / 06 / 2007)$.

Não é de menor importância o papel da indústria cultural, em sua atuação no assentamento, na adaptação do assentado à lógica do sistema capitalista.

A indústria cultural, com seu caráter regressivo, trabalha pela adaptação do homem e sua aceitação passiva de uma realidade social que violenta suas condições de existência digna, ao contribuir para reforçar a aparência de que o indivíduo é livre em suas escolhas, ao mesmo tempo em que mecaniza o pensamento, induz a uma recepção passiva, desacostuma o indivíduo com o exercício de pensar e questionar, homogeneíza os comportamentos e a consciência dos indivíduos segundo o padrão socialmente aceito, que no nosso caso, é o padrão urbano e consumista. 
Ao reforçar padrões de consumo urbano, a indústria cultural contribui para inserir os assentados na lógica do mercado, suscitando o desejo por bens e produtos cuja necessidade é veiculada pelas propagandas, os quais os assentados nem sempre realmente necessitam, mas que podem fazê-lo se sentir igual aos colegas que vivem na cidade, ou seja, podem fazê-lo sentir que obteve sucesso na vida em função de sua opção de vir para o acampamento.

Aquilo que Adorno (1996, p. 393) vai chamar de "incultura no estilo antigo", que consistia simplesmente na não chegada das informações e da educação no campo, foi substituído pela semi-cultura. Através da entrada da indústria cultural nas zonas rurais, com a ajuda do rádio e da televisão, a cultura camponesa, em geral ligada às tradições religiosas, foi substituída pelos mesmos produtos da indústria cultural que são "vendidos" na zona urbana. Nas palavras de Adorno (1996, p. 393), “o campo foi conquistado espiritualmente pela indústria cultural".

No assentamento não é diferente. Os assentados são tão consumidores desses produtos quanto seus parentes, colegas e conhecidos que vivem nas periferias das cidades próximas ao assentamento. Com relação aos chamados "bens culturais", as preferências dos assentados acabam por serem idênticas aos apresentados pelos moradores das cidades próximas. Nesse sentido, a indústria cultural absorveu alguns elementos da cultura tradicional rural, simplificou-a e criou produtos vendáveis, cujos conteúdos estão eivados pela temática urbana, mas travestidos de "tradição rural".

A influência da cidade sobre o campo é infinitamente superior à influência do campo sobre a cidade, mesmo no caso de municípios considerados rurais, isto é, que vivem e existem em função de sua zona rural. Em sua atuação no campo, a indústria cultural atua difundindo os valores eminentemente urbanos e industriais, naturalizando esses padrões de 
comportamento e consumo e adaptando o assentado à lógica urbana. Esses valores reforçam uma visão do homem e da vida no campo como inferior e atrasada em comparação com a vida industrial e urbana das cidades. Essa inferiorização contribui com uma mudança nos valores do meio rural, subordinando-os aos valores dominantes na sociedade, e naturalizando sua adaptação ao sistema capitalista em uma posição subalterna e inferior.

A apresentação da vida urbana como superior, aprofunda uma visão negativista de ser camponês ou de ser trabalhador rural, identificado como atrasado e "caipira", visão essa assumida pelos próprios assentados, o que também justifica sua tentativa de serem mais reconhecidos pelos agentes externos. Alguns dos assentados que foram entrevistados, antes de conceder a entrevista, perguntavam por que alguém 'da faculdade ia querer entrevistar alguém que não teve estudo?' ou quem 'só entende da enxada?'. A esse respeito, nos fala Sr. Ivan:

"Vim pra cá em 2004, no acampamento. E aí... aí eu tornei a voltar às origens, entendeu, porque eu sempre gostei de viver assim, quase no mato mesmo porque... as vezes as pessoas da cidade pensa que o homem... o camponês, o homem do campo... ou em outras palavras, o 'capiau da roça' que nem diz, o caipira... eles acham que são pessoas fora da sociedade, né, enquanto essa inclusão social acaba levando a gente a ter prazer. Eu as vezes me orgulho de ser caipira porque... é daqui que tiramos os alimentos que os grandes, os grandes inteligentes as vezes consomem, só que as vezes não se dá conta que é da roça que vai o alimento para a mesa dele, não é do mercado.” (Sr. Ivan, entrevista). 
Nesse sentido, a indústria cultural funciona como um reforço do desejo de querer ser igual, contribuindo para substituir a resistência ativa e a consciência pelo conformismo. Assim, concorre para o esmorecimento e para a perda da experiência, ao reforçar a introdução do indivíduo no espírito dominante dessa sociedade, e ao diminuir a capacidade adquirida na luta pela terra de pensar autonomamente e de decidir por si mesmo as coisas.

Não que os interesses materiais e o desejo de ter coisas sejam em si negativos. Assumir essa postura leva a uma romantização e a um elogio da pobreza, bem como a uma consideração da falta como um valor em si, o que de certa forma implica em legitimar o sistema que permite que vastas populações vivam sem acesso e a benefícios que estariam já disponíveis para todos.

O problema não é o desejo de ter algumas coisas, mas o caráter regressivo e compulsivo desse desejo, que é moldado pelos programas de televisão e de rádio, pelo que o sistema capitalista acha que os indivíduos devem achar que precisam, transformando as necessidades humanas em objeto de manipulação no interesse do lucro segundo o que a indústria está produzindo e quer vender naquele momento.

Um exemplo desse tipo de consumo moldado pelo padrão urbano, compulsivo e desnecessário, além da compra excessiva de tratores e implementos agrícolas pontuadas acima, foi o do assentado que com o dinheiro do "Fomento"12, comprou uma moto sem documento, para andar somente dentro do assentamento, pois considerava "cansativo" caminhar a pé dentro do Sepé Tiaraju, sendo que a área deste é consideravelmente pequena. A moto foi tão sub-utilizada que o assentado a vendeu após alguns meses.

\footnotetext{
${ }^{12}$ O crédito de "Fomento" é um recurso a fundo perdido, e no caso do Sepé Tiaraju, se efetivou através de duas parcelas de $\mathrm{R} \$ 2.400,00$ cada.
} 
Quanto às atividades culturais no assentamento, segundo é pontuado pela própria liderança, essas ocorrem em poucas ocasiões, estando ainda em um processo de construção.

Durante o desenvolvimento da pesquisa, o que se pode acompanhar de atividades culturais foram a realização de festas juninas, por dois anos seguidos, e com a participação intensa dos assentados; a festa de inauguração do assentamento, para a qual a liderança do MST convidou um músico de moda de viola bastante reconhecido, bem como a participação de alguns assentados nos Encontros de moda de viola ocorridos na sede regional do MST, o Sítio Pau D’Alho.

Os assentados também narram a participação em alguns eventos de caráter políticocultural, como a participação de algumas mulheres assentadas na passeata do dia das mulheres na cidade de São Paulo (onde inclusive foram agredidos da polícia) e a realização de uma atividade de conscientização novamente no dia das mulheres, dessa vez na cidade de Serra Azul.

Assentados ligados à direção ou "militantes" têm maior clareza da importância da cultura, da formação, do trabalho reflexivo, bem como da alienação alimentada pela indústria cultural, e de como é difícil romper com isso.

Além disso, também pontuam com maior facilidade as condições objetivas de existência que dificultam ou impedem a realização de um trabalho mais efetivo de fomentar cultura, entre elas o fato das condições de reprodução e de subsistência das famílias assentadas ainda não estarem garantidas:

"Nós tamos de um modo geral, nesses dois anos - a gente tá indo pra três anos de assentamento - eu ainda vou naquela idéia, enquanto você não tiver mais ou menos sossegado, enquanto você tiver tendo dificuldades, 
você ainda não vai... se você não tiver com um dinheiro no bolso, você não vai num cinema em Ribeirão Preto, ou de ir numa festinha ali, então não tem aquele ânimo... nós fazemos alguma coisa, tamos ainda com um pessoal da igreja ali, então a gente começa a fazer umas reuniões, vamos falar, uma missa, fizemos uma festa de inauguração do assentamento, teve um grupo aí de folia de reis, pequeno, mas teve. Acho que vai formando essa consciência quando a gente vai ficando livre, porque tinha um tempo que a gente tinha que correr para plantar, correr para fazer casa, mas acredito que a gente vai conseguir fazer cultura aqui também. Tá vindo agora as festas juninas, temos ainda que explorar também os costumes culturais de outras regiões, porque aqui nós temos paranaense em grande quantidade, temos mineiros, temos baianos. (Sr. Marco, entrevista).

Também manifestam uma clareza quanto a influência da indústria cultural na formação dos hábitos culturais dos indivíduos, dando especial destaque à influência da televisão e do rádio, no caso do assentamento:

\footnotetext{
"As pessoas são influenciadas, né, influenciadas pela televisão, influenciadas pelo que passa no rádio, as pessoas gostam de pancadão, mesmo, forró, forrózão bruto.” (Sr. Vitor, entrevista).
}

Outro fator apontado como dificultador do desenvolvimento de atividades culturais, de lazer, e de formação é a ausência de locais adequados para se desenvolver tais 
atividades, ou simplesmente para as pessoas se encontrarem e trocarem experiências, fomentando assim a reflexão e o contato entre os assentados:

"Não temos ainda um espaço cultural pra gente..., mais alguns jovens que estão hoje trabalhando com isso. Mas se pode ver aqui, nós não temos... temos o campinho que foi feito mal-feito, que tem pedra, nunca mais vi ninguém jogar bola, não tem um joguinho de malha, a gente não senta ali pra bater uma prosa, pra jogar uma conversa fora, então eu acho que isso vai amadurecer com o tempo." (Sr. Marco, entrevista).

Cabe pontuar que o campo de futebol foi feito às pressas pelo governo federal (INCRA), para estar pronto para a inauguração do assentamento, ocasião na qual também foram plantadas várias árvores na área coletiva, para que ela ficasse apresentável, bem como foi ligado o poço de água com um pequeno gerador, para dar a impressão que estava funcionando, quando na verdade somente passou a funcionar cerca de um ano e meio depois.

Se a liderança do MST tem clareza do papel e da influência da indústria cultural na formação dos hábitos, na submissão dos indivíduos ao capital, e na constituição de indivíduos semi-formados e, consequentemente, alienados, por outro lado, a forma como alguns assentados dizem que o Movimento faz a crítica, taxando publicamente de "lixo cultural" o "gosto" de alguns deles, faz com que eles fiquem resistentes às alternativas, bem como os ofende sobremaneira: 
"Em vez da Direção vir e conversar, chega impondo... cê vê, até na música, que o povo ouve eles querem dar palpite, falam pra eles que é 'lixo cultural'... tudo bem que é ruim mesmo, mas não é falando assim que você vai mudar a pessoa... ela só ouvia isso na cidade, então pra ela ouvir outras coisas tem que mostrar pra ela, sei lá, trazer alguém aqui para cantar, não precisa ser famoso, mas para ela com o tempo ir aprendendo a gostar de um Chico César, de uma Elis Regina... você tem que conquistar a pessoa [...]” (Sr. Gilson, Diário de Campo, p. 47, 13/11/2006).

O que pudemos perceber é que o MST tenta oferecer alternativas à indústria cultural, que são bem aceitas pelos assentados. Uma dessas ocasiões ocorreu na inauguração do assentamento, para a qual o Movimento convidou um famoso violeiro, de reconhecida qualidade nos círculos de moda de viola do país. Os assentados gostaram muito do evento, tendo participado bastante, dançando inclusive homem com homem, tendo-se em vista que falta mulher no assentamento. Essa festa foi comentada por meses no assentamento.

Do que se pôde depreender da participação dos assentados nas atividades culturais propostas, é que há abertura e interesse em participar desses eventos. Em realidade, a música e outras manifestações culturais da zona rural que o MST tenta resgatar, não são completamente estranhas aos assentados, tendo-se em vista que os indivíduos possuem algum contato com ela, se não a vivenciando em seu dia-a-dia, reconhecendo parte dessas manifestações na cultura de suas famílias de origem. 
Outrossim, há uma grande aceitação mesmo com relação às manifestações culturais diferentes daquelas as quais se está acostumado, eventualmente em função da carência de atividades lúdicas e de lazer no Sepé, havendo então possibilidades para o desenvolvimento da cultura alternativa no assentamento.

Quanto à questão de preservar a cultura urbana, que é um dos objetivos da Comuna da Terra, através da realização de atividades urbanas como o hip-hop, não presenciamos a realização de nenhuma atividade nesse sentido, tampouco os assentados se referiram a algo durante os dois anos que acompanhamos o assentamento.

Além disso, há uma contradição na valorização da cultura do camponês, que se dá de maneira fragmentada: a moda de viola pode, porque se contrapõe ao "lixo cultural" produzido pela indústria cultural; já o mutirão para a construção da casa de alvenaria não pode, porque se contrapõem ao modo de funcionamento em brigadas, que é considerada uma forma de organização superior em comparação às formas tradicionais ${ }^{13}$.

Cabe pontuar que parte das formas que são hoje tratadas como "tradição", como por exemplo, o mutirão ou 'ajutório', foram utilizadas e introduzidas em algumas áreas da zona rural como uma forma de luta política pelo PCB, nos anos cinquenta (SCHEREINER, 2002).

Durante o desenvolvimento do trabalho de campo, foi possível perceber que vários assentados cultivam o hábito da leitura. Um exemplo é o Sr. Marco, que já foi ligado à direção e hoje está afastado, e que constantemente está lendo jornais e teóricos de esquerda, como Mariátegui. Esse senhor sempre procura estar inteirado de tudo o que acontece no

\footnotetext{
${ }^{13}$ As formas tradicionais, consideradas simples, são aquelas que surgem de maneira espontânea, fazem parte dos hábitos culturais e da tradição camponesa, podem ser a ajuda mútua, a "troca de dias", o mutirão, etc... As formas de organização consideradas superiores são aquelas planejadas e que envolvem a divisão de trabalho como meio para levar à construção de uma nova consciência. Exemplos de cooperação complexa e superior são a agroindústria e as cooperativas agropecuárias de produção (STÉDILE; FERNANDES, 1999).
} 
mundo (crise nos Estados Unidos e mundial e seus mecanismos de origem, o PAC - Plano de Aceleração do Crescimento, a Dilma como candidata) e na política local (prefeitos da região) e nacional, apresentando uma certa predileção pela discussão teórica e política.

Além do Sr. Marco, são comuns as situações onde encontramos assentados lendo alguma coisa, dos mais variados tipos, desde assentados que lêem filosofia ou artigos acadêmicos, em especial aqueles sobre o próprio assentamento, até assentados que se dedicam à leitura da Bíblia ou de romances "cor-de-rosa", como "Sabrina". É grande o número de assentados que se dedica a leitura de livros técnicos e sobre agroecologia.

Assim, muitos assentados, independentemente de serem da liderança, mantém o hábito de ler e estudar, seja porque já tinham esse costume, seja porque adquiriram na luta. Por outro lado, vários assentados verbalizam a necessidade de terem uma formação maior e mais adequada, seja na parte técnica, seja com relação à educação e cultura em geral:

"Se você não tiver feliz ou se você não tiver um dinheiro pra você... (...) você vai lá pra Ribeirão pro teatro, vai assistir uma peça, isso aí que vai... quer dizer, a educação pra nós vai ficando mais difícil, se você não tiver um dinheiro você não vai se educar pra ver uma peça, (...) nós somos pobres porque somos mal-educados, e quanto mais a gente demorar pra conquistar um recurso, então você não vai adquirir mais conhecimentos." (Sr. Marco, entrevista).

“[...] Falta capacida... capacitação, então um monte de coisas que aí acaba juntando, aí cê acaba dando um choque também, aí não avança, então, 
por exemplo, aí vêm os recursos do INCRA, mas aí as famílias não tão capacitadas adequadamente pra encarar, aí acaba... as vezes cê quer fazer um projeto, o INCRA quer outro, aí acaba dando um monte de choque." (Sr. Geraldo, entrevista).

A falta de formação técnica, no presente caso, é um complicador a mais para o desenvolvimento do assentamento, tendo-se em vista que vários assentados não têm origem rural, não conhecendo inclusive o trabalho de produção agropecuária, que é bastante complexo e repleto de técnicas específicas. O trabalho agroecológico é mais difícil ainda, exige outros saberes especializados e demanda mais mão-de-obra e atenção. Essas dificuldades podem inclusive acarretar desistências e, somadas a outras, levar ao arrendamento ou à descaracterização do assentamento.

\footnotetext{
"Essa semana veio uma senhora aqui chorando, ela estava desesperada chorando porque... ela falou assim que o lote dela tava todo bagunçado, e que... é uma pessoa que teve muita dificuldade que não deu mesmo pra fazer, porque é fazendo que... (...). Cê vê esse rapaz que tá aqui, ele tá fazendo um serviço porque meu marido não sabe fazer... então, eu falei pra ela, 'olha, cê tem que se acalmar, e começá a trabalhar, porque é aos poucos, cê vê, uma criança, ela leva nove meses no ventre pra ela se formar, aqui na roça também não é diferente, nós temos que ir trabalhando, e aos poucos vai'...”. (Sra. Simone, entrevista).
}

Cabe comentar aqui que ainda está em funcionamento, já há três anos depois de assentado, o coletivo de educação, bastante discreto, mas com uma atuação significativa. 
Funciona com três pessoas, duas mulheres e um homem, sendo que todos são bastante ativos e com conteúdo, as duas primeiras são bastante discretas, e o terceiro é mais expansivo, mais comunicativo, e acaba por assumir o papel de porta voz do grupo. Esse coletivo tem um trabalho de estímulo à leitura, principalmente com crianças e adolescentes, e para isso utilizam os livros de um projeto do MDA (Ministério do Desenvolvimento Agrário), o projeto de bibliotecas rurais Arca das Letras.

\subsection{O assentamento e a relação com o INCRA}

Dentre os vários segmentos do Estado que possuem alguma atuação junto ao assentamento, aquele que está revestido de maior importância é o INCRA - Instituto Nacional de Colonização e Reforma Agrária, cuja presença no assentamento é constante e intensa e, por vezes, maior do que a do movimento social.

Como já relatamos anteriormente, o assentamento Sepé Tiaraju tem sido utilizado pelo INCRA e pelo MST estadual como experiência-modelo. Ele foi o primeiro assentamento no formato PDS implantado pelo governo federal no Estado de São Paulo, sendo que hoje existem mais oito novos assentamentos homologados segundo esse novo modelo, e há a pretensão de se criar mais.

Se o INCRA considera o Sepé como modelo, os assentados no Sepé, ao contrário, tecem várias críticas à atuação do governo federal. Assim, Vitor, membro da direção regional do MST e assentado no Sepé Tiaraju, discursa em um protesto nos seguintes termos: 
que em todo lugar que o INCRA vai usa o nome deles, usam-nos como modelo de assentamento, que eles estavam ali para dizer que o Sepé não é aquela maravilha que o INCRA fala, para fazer nome em cima deles, que a parte deles (INCRA) eles não fazem (Diário de Campo, p. 126; 25/04/2007).

Já outros dois assentados, membros da Agro-Sepé, Ivan e Arthur, comentam que

\begin{abstract}
A água ainda não saiu, que a luz que era menos importante já saiu, e que no dia de inauguração do assentamento, o poço tava lá jorrando água para mostrar que o INCRA tava trabalhando, mas que no vamos ver mesmo, o INCRA ainda tem o prazo de um ano para colocar os canos para distribuir água, então não tem água ainda. Falaram que com a luz foi a mesma coisa, mostraram a luz funcionando no dia da inauguração do assentamento, mas aquela luz era de um geradorzinho escondido atrás de uma caixa d'água. Disseram que o governo só faz propaganda às custas do povo (Diário de Campo, p. 110; 15/03/2007).
\end{abstract}

A assistência técnica é realizada tanto por técnicos contratados pelo INCRA através de um convênio com a FEPAF (Fundação de Estudos e Pesquisas Agrícolas e Florestais), quanto por técnicos contratados pela CCA (Cooperativa Central de Reforma Agrária de São Paulo), uma das figuras jurídicas do MST, com recursos repassados pelo governo federal/INCRA. 
Na verdade, o INCRA e os técnicos contratados através do convênio da FEPAF são responsáveis pelas questões administrativas e de infra-estrutura. No caso da assistência técnica propriamente dita (orientações agronômicas), o INCRA repassa recursos federais, através de convênios, para contratação de técnicos terceirizados para prestação de assistência técnica.

Tentando explicar melhor, hoje existem três tipos de técnicos ligados ao INCRASão Paulo, e trabalhando dentro dos assentamentos de reforma agrária: os funcionários públicos efetivos (concursados); os funcionários temporários e terceirizados, contratados através de convênio com a FEPAF; e os pagos pelo governo federal através de repasse de recursos públicos para entidades privadas, tipo ONGs, como é o caso do convênio firmado com a CCA, ligada ao MST.

No caso do assentamento Sepé-Tiaraju, existem técnicos dos dois últimos tipos prestando serviços ali dentro: os temporários do INCRA/FEPAF, e os contratados pelo MST. Quando do início das observações, o INCRA contava com dois técnicos FEPAF no assentamento (Augusto e Helena), e a CCA (MST), com mais dois, Margô e Alexandre. Dos técnicos do MST, com o passar do tempo, a primeira se desligou da função, deixando só o segundo. Em seguida, por desentendimentos com parte dos assentados, o técnico contratado pelo MST passou a prestar assistência a poucas famílias e, com esse acontecimento, a assistência técnica no assentamento passou a ser demandada dos técnicos contratados pelo INCRA/FEPAF.

Dos quatro técnicos inicialmente contratados, três eram agrônomos e um zootecnista. Esse perfil dos técnicos, tanto do INCRA quanto do MST, revela que a preocupação de ambos está voltada primordialmente para as questões de produção agrícolas. Falta aos assentados uma assistência técnica na área social, essencial em um 
momento de surgimento de uma nova comunidade, visto que os assentados apresentam total desconhecimento quanto aos seus direitos sociais, como INSS, com os quais estavam desacostumados; bem como há situações de conflito que poderiam ser mais bem trabalhadas com um apoio técnico na área social.

Até o presente momento, somente dois assentados têm sua DECA (Declaração Cadastral de Produtor), que é a inscrição desse produtor na Receita Federal, que o autoriza a tirar um talonário de notas fiscais. Ao se inscrever na DECA, o assentado passa a ser oficialmente produtor rural, e passa a ser reconhecido como tal pelos vários entes governamentais, nos seus vários níveis. É a DECA que garante a aposentadoria daquele trabalhador rural, pois de cada nota fiscal que ele emite, $2,1 \%$ é recolhido, pelo comprador, para o INSS. Os assentados estão esperando a regulamentação da Agro-Sepé, para tirarem uma DECA coletiva, das oitenta famílias assentadas.

O perfil dos técnicos contratados, que é ligado à produção, também traz complicações neste aspecto: o DECA é essencial para as famílias acessarem seus direitos previdenciários, deve ser feito imediatamente ao assentamento, e constar o nome no documento de todos os familiares que trabalham no lote. De certa forma, ele é o equivalente à "carteira de trabalho" do trabalhador rural que produz em regime de economia familiar. O fato de fazer somente uma DECA para as oitenta famílias vai dificultar a aposentadoria dos cônjuges, em especial das mulheres. Essas informações simples são desconhecidas por profissionais com formação estritamente técnica na área de agronomia, mas conhecida por qualquer profissional de humanas que trabalha com políticas públicas na área rural. Cabe pontuar que nenhum das mulheres assentadas que tiveram filhos nesse período de quatro anos de assentamento conseguiu acessar sua licençamaternidade, por falta da DECA. 
Para alguns assentados, especialmente os ligados à liderança, um dos pontos negativos do governo federal é que ele não faz o assentamento de forma planejada e organizada, o que complica e tumultua todo o início da formação da comunidade e da produção, e que a longo prazo pode causar um novo êxodo rural:

\footnotetext{
“Se não tiver uma política sustentável, que leve em conta de ter mesmo o indivíduo no campo, não vai ficar ninguém no campo, porque equipe técnica é péssima, agora que tá melhorando um pouquinho, mas é muito pouco técnico pra atender os assentados, os recursos ainda é mal aplicado por falta de capacitação e de equipe técnica, e... então quer dizer... daqui a médio prazo, cê vai ter um monte de gente voltando pra cidade de novo... mas culpa de quem? Dos indivíduos? Não, culpa do governo, porque tem política pros usineiros, negocia conta pra cem anos, duzentos anos, mas pro pequeno produtor não tem né, então é onde que a gente tem que olhar com carinho pra esse lado, pro desenvolvimento econômico da pequena produção" (Sr. Geraldo, entrevista).
}

A falta de infraestrutura no assentamento, cuja maior responsabilidade é do governo federal, tem causado muitos problemas e dificuldades para os assentados. Desde a ocupação da fazenda Santa Clara, que como vimos ocorreu em abril de 2000, até o final de 2008, não havia sistema de água implantado. Alguns assentados tinham que caminhar até quatro quilômetros para conseguir um balde de água. Também houve falta de um planejamento em etapas para a organização mínima do assentamento, ou seja, água, energia elétrica, habitação, formação técnica para os assentados e recursos para início da produção, sendo que as etapas foram realizadas de forma aleatória e confusa, prejudicando 
a própria estruturação satisfatória das famílias assentadas. Nesse sentido, a falta de planejamento estatal prejudica o desenvolvimento das famílias, bem como induz o próprio assentamento a "não dar certo". Como diz um assentado:

"Então eu acho assim: tem que primeiro providenciar a moradia, né, tem que ter água, tem que ter energia, e aí ele tem que ter o recurso mó dele poder investir na produção, mas isso, tem que tar junto, tem que tar dentro de um pacote onde uma coisa tá junta com a outra, aí as coisas... sai uma coisa e não sai a outra... Por exemplo: saiu o poço, mas não saiu a rede de água, então quer dizer, como é que você vai desenvolver o seu recurso no seu lote sem água, já muita gente comprou animal e um monte de animal morreu por falta de água. E aí? Foi culpa das famílias? Não foi, foi culpa do próprio INCRA que não avaliou isso antes. Porque antes de sair o recurso tinha que sair a estrutura, que era a água. As casas, por exemplo, saiu o projeto das casas, mas quem disse que tinha água pra fazer casa, quando começou a fazer as casas, não tinha. É... a estrada, né... primeiro veio a medição dos terreno, tudo bem, aí segundo as estradas, legal, terceiro seria a moradia, que aí demorou mais pra vim, a moradia chegou junto com os recursos, óia só pro cê ver, como você vai cuidar de moradia e trabalhar ao mesmo tempo? Então quer dizer, as coisas vem tudo de uma vez, tudo tumultuado, que aí cê não sabe o que qui cê acode primeiro. Então isso também é uma falha na questão da estrutura." (Sr. Geraldo, entrevista). 
De acordo com os assentados, a produção, que já é grande, poderia ser triplicada se eles tivessem as condições mínimas, e eles poderiam pagar os custeios com tranquilidade:

“Como aqui é um assentamento modelo, e falta a água? (...) Nós já tamos pra quatro anos que foi aqui decretado um assentamento. Pro governo federal, com menos de dois anos já era pra ter ponhado o essencial aqui dentro (...) a CPFL, quando nóis exigimo dela, ela já tava em cima, colocou tudo, porque, pra CPFL, ela tem um grande interesse, que a Luz Para $\operatorname{Todos}^{14}$ para nós não dava, (...) então ela teve o interesse em receber. Agora eu pergunto: se já tivesse a água aqui, era muito melhor pro governo federal, porque o governo gasta muito mais aqui sem ter a água. Por que, Arthur? Porque o governo federal gastaria menos? Gastaria menos, porque o que ele nos investiu, a gente poderia triplicar ou mais. A gente recebeu, gastou um pouco em lavoura, gastou outro pouco em outras coisas que perdeu, como fruta, porque nóis não tinha a água, se nóis tivesse a água, nóis tinha um império de produção aqui” (Sr. Arthur, entrevista).

Dentro dessa compreensão, há uma política deliberada de desestímulo à fixação do homem no campo. O fato do governo liberar o dinheiro do custeio e do investimento na produção (PRONAF) antes das famílias terem uma capacidade mínima de começar a produzir é entendido como uma forma de desorganizar e de desestimular essas famílias, que vão acabar utilizando mal os recursos, e não terão como pagar o empréstimo, acabando no

\footnotetext{
${ }^{14}$ Programa Luz Para Todos do Ministério de Minas e Energia (LPT/MME), programa de eletrificação rural, que pode ser acessado pelos assentados para garantir a instalação de energia elétrica, inclusive até dentro da casa, de forma gratuita.
} 
final das contas com o "nome sujo" nos bancos, bem como com a pecha de mausprodutores e desonestos, que não utilizam adequadamente os recursos públicos.

\footnotetext{
"O mais difícil agora na época de assentamento é questão de recurso. Porque quando vem recurso do governo, ele vem um recurso tão pouco, que na verdade ele tá endividando o assentado. Ele não vem um recurso que o assentado ele tem como fazer uma produção que ele tem uma renda pra que aquele recurso seja até pago. Parece que já é feito até mesmo de propósito. Porque quando a pessoa chega num nível de assentamento, a gente foi chegar no assentamento com oito anos de luta, então não tem mais nada, até o fogão véio que já trouxe da cidade, aquilo já se destruiu. Então ele tá cozinhando na 'trepe”, né, feito na lenha. Então, essa é uma dificuldade muito grande.” (Sr. Angelo, entrevista).
}

O governo federal usa uma racionalidade técnico-burocrática, que homogeneíza os assentados, e não considera as diferenças pessoais. Exemplo dessa atuação técnicoburocrática é a questão da água, que sempre foi essencial no presente assentamento, e que foi a última a ser equacionada (na verdade, não está completamente equacionada), por questões administrativas e burocráticas. Como eram necessárias licitações para a instalação dos canos de água, o INCRA protelou o investimento. Quando foi liberada a realização da licitação, já não havia mais verba disponível naquele ano para a realização do investimento, sendo que a instalação atrasou mais um ano então, e desde a homologação do assentamento, os assentados ficaram quatro anos sem água. Contando o tempo do acampamento, são oito anos sem água. 
Outro exemplo da atuação do governo federal, cujo planejamento se dá a partir de questões burocráticas que desconsideram completamente o assentado foi a entrega da biblioteca do projeto Arca das Letras do assentamento. Contam os assentados que alguém bateu na porta do barraco de um deles, o Sr. Ivan, presidente da associação, lá pelas duas da manhã. O referido assentado conta que "quase morreu do coração", e pensou em sair correndo pela janelinha dos fundos, pois achou que tinham vindo para "pegar ele" (sic). A hora que a pessoa se identificou como motorista do INCRA, Sr. Ivan disse que teve vontade de "brigar com o cara". Segundo o motorista, a Arca (estante de madeira para livros) foi entregue nesse horário porque ele teve que deixar uma série de coisas em outros locais na região, deslocando-se por vários assentamentos de diferentes cidades do noroeste paulista, e como segundo ordens superiores a biblioteca tinha que ser entregue naquele dia, só tinha sobrado aquele horário para deixá-la no Sepé Tiarajú (Diário de Campo, p. 110, 15/03/2007).

Um exemplo da homogeneização pode ser dado com o projeto de construção da casa. O INCRA e a Caixa Federal liberaram um montante de R $\$ 13.900,00$ para ser utilizado com a construção das casas das famílias assentadas, com a exigência de que as casas fossem completamente construídas (do alicerce ao acabamento), bem como legalizadas (com planta). Alguns assentados não puderam ter acesso a todo o crédito, em função de já terem sido mutuários da Caixa Econômica Federal, sendo que para esses somente seriam liberados $\mathrm{R} \$ 5.000,00$, referentes à parte disponibilizada pelo INCRA. A fim de garantir a construção das casas, o governo federal, através de reuniões com os assentados e com a contratação de um grupo ligado a uma universidade (HABIS), disponibilizou quatro modelos de casas que poderiam ser construídos com esse valor, 
segundo pesquisa de mercado realizado pelo HABIS, e os assentados teriam que escolher entre um desses modelos para construírem. Como nos conta o Sr. Ângelo:

"Igual, agora tá tentando a questão com a Caixa [Caixa Econômica Federal], e isso daí não é tudo e não ajuda muito, porque vem a parte da dominação, aí a pessoa começa a ter que fazer aquilo que a Caixa qué, aquela 'egigência' do engenheiro, então acaba entrando no campo da dominação a mesma coisa. Então a pessoa, ele acaba não tendo muita liberdade. (Sr. Angelo, Entrevista).

Há que se pontuar também uma postura autoritária do governo federal, em específico do INCRA, bem como dos técnicos que nele atuam, que determinam a forma como devem ser feitas as coisas, tratando o assentado como alguém que não pode decidir por si só, o infantilizando. Um bom exemplo disso foi a discussão sobre o trabalho coletivo. Com a sinalização de que sairia o PRONAF-investimento para os assentados, no valor de $\mathrm{R} \$ 16.500,00$, os técnicos do INCRA fizeram reunião em cada um dos núcleos, para fazer o projeto que o banco exige para a liberação do dinheiro. Nessas reuniões, era perguntado o que cada assentado queria fazer no seu lote, quanto de dinheiro ele pensava em colocar no individual, e quanto na parte destinada à produção coletiva.

Augusto [técnico do INCRA] disse que era só para ter uma idéia, que eles como técnicos iam fazer o projeto, e colocar o quanto era necessário [no coletivo], se $\mathrm{R} \$ 7.000,00$; se $\mathrm{R} \$ 8.000,00$, eles iam ver a hora que colocassem no papel. (Diário de Campo, p. 116, 16/03/2007). 
O autoritarismo de tal postura é patente: os assentados são tratados de forma infantilizada, e até a autonomia para decidirem como gastar o dinheiro emprestado em seu nome lhes é tirado. Desta maneira, o assentado acaba por perder o poder sobre seu próprio nome, tendo em vista que este é empenhado para fazer os gastos segundo a determinação e o desejo dos técnicos do governo federal.

Caume (2002) vai pontuar a atuação do Estado no espaço do assentamento como uma tentativa de controlar e tutelar o assentado, tentando colocá-lo em uma situação de passividade e submissão frente às forças estatais. Tal controle é tentado a partir de mecanismos de seleção e exclusão dos beneficiários, de políticas públicas e sociais, e da própria assistência técnica. Ao assinar o "documento da terra" (concessão de uso), o assentado declara estar de acordo com uma série de normas, que versam desde a organização da produção, até a organização da vida, e que devem ser cumpridas sob pena de exclusão. A própria representação política é obrigatória, pois o assentamento no modelo PDS exige uma associação para existir legalmente.

A atuação normativa do governo federal procura se estender a todos os aspectos da vida do assentado, a partir de uma lógica que coloca em primeiro plano a questão produtiva. O livre arbítrio do assentado, inclusive sua liberdade para poder errar, fica submetido às questões de produção.

Para Adorno (1992, 1986), o Estado atua como agente do capital, como agente da racionalidade instrumental, reforçando os mecanismos de dominação e de reprodução do sistema, ou seja, de adaptação dos indivíduos ao mundo administrado. Em certos casos, o Estado até mesmo renuncia a sua aparência de independência, e atua a serviço de interesses particulares, mormente a reprodução do capital e do todo societário. 
O governo federal contribui assim para que o assentamento seja absorvido pelo mundo administrado, passando a atuar em consonância com este, com suas regras e sua sanha de ordenamento de todas as manifestações da vida, no interesse da produção e do lucro. Além disso, contribui para a infantilização e a regressão do indivíduo.

No que diz respeito à interação mantida entre o INCRA e as lideranças do MST dentro do assentamento, pode-se perceber uma relação dúbia e tensa. Por um lado, os técnicos do INCRA reforçam a atuação do Movimento, que por sua vez recorre várias vezes ao INCRA. Por outro, há uma disputa de espaço e de modelos, com troca de acusações mútuas. Assim, Geraldo, assentado que já conhecemos e que é militante do MST, fala

sobre a intervenção do Estado, que quer fazer valer no assentamento sua visão do que é melhor, o que atrapalha bastante e gera uma disputa de modelos, mas que demora pra liberar os créditos; fala da casa, da luz, e só frustra o assentado, que era 'melhor nem falar, né!?', e que o assentamento devia 'ser feito como um negócio mais pronto, mais adiantado'(Diário de Campo, p. 100; 30/01/2007).

Por outro lado, os técnicos do governo federal falam sobre a atuação da liderança local do MST:

[O agrônomo] falou da falta de união, e que o MST parece que não consegue mais organizar os assentados, que achava que eles - dirigentes do MST - deveriam fazer alguma coisa, pois eles - técnicos - são o 
Estado, e eles não podem confundir papéis (Diário de Campo, p. 169; 27/06/2007).

Também há uma culpabilização dos técnicos do INCRA como indivíduos pela ausência ou atraso na efetivação de políticas públicas no assentamento, que são personalizadas e vistas como decorrentes da ação do agente estatal, e não como decorrência do tipo de lógica e de intervenção promovida pelo Estado:

\footnotetext{
"Um pai de família tem dez filhos, a intenção do pai é de que todos os filhos se formem, sejam bons alunos, bons estudiosos, mas dentro daqueles dez filho lá, pode ser que quatro, cinco, seis até que vai bem conforme as ordens do pai, porque o pai é o cabeça da casa, e eles vai bem com as ordens do pai... mas o que que eu quero dizer? O governo federal, ele tem boas intenções, mas até chegar ni nóis já passemo por um monte de bandido, funcionário bandido, até chegar ni nóis aqui... eu sou feliz, mas pela rebeldia, e pelo que já conquistei, e não pelo desenvolvimento da equipe que o governo elege ela praquilo." (Sr. Arthur, entrevista).
}

A personalização da culpa pela falha das políticas públicas, que é colocada nos agentes estatais (como pessoas e não na organização do Estado em si) leva a desentendimentos e choques, dessa vez com os técnicos, bem como a um excesso de pressão sobre esses funcionários. Durante o decorrer da pesquisa, um dos agrônomos estatais pediu demissão por pressão do Movimento, que o culpava por não ter saído a água 
ainda, sendo que o órgão estatal (INCRA) não tinha sequer provisionado a verba para se iniciar a licitação.

Interessante registrar que presença estatal no assentamento, através principalmente do INCRA, diminui o poder do MST, no sentido de que o assentado não tem mais que seguir as orientações ou prestar contas a este último, podendo inclusive nem se relacionar mais com o Movimento. Passa agora a ter que prestar contas e se relacionar apenas o Estado, que vai tentar normatizar o seu comportamento, por meio de compromissos firmados na época de recebimento do "documento da terra", ou mesmo de Termos de Ajustamento de Conduta (Diário de Campo, p. 63,14/12/2006; p. 147, 08/06/2007).

No assentamento, já não é mais o MST quem preside ou conduz os processos de decisão das questões de exclusão ou de disciplina, como era na época do acampamento. Esses passaram a ser responsabilidade do INCRA, que passa a ser o juiz do comportamento daquele assentado como produtor rural. Nesse sentido, o Movimento passa a precisar da aquiescência do governo (ou dos técnicos estatais) para fazer valer seus modelos ou para manter sua força de influência dentro do assentamento.

Ao mesmo tempo, há uma proximidade do MST com a atual superintendência do INCRA, o que lhes concede ascendência sobre os técnicos que estão realizando o trabalho no assentamento:

\footnotetext{
“Ó, eu vou ser sincero com você, acho que não sei se eu vou falar tudo de uma vez com você: porque o INCRA é manipulado por eles, a equipe do INCRA que tá aqui é manipulada por eles, eles usam essa ameaça: 'ah, porque o INCRA vai mandar oceis embora, porque o INCRA vai não sei o que, porque o INCRA tá na nossa mão, porque o INCRA tem que
} 
obedecer nóis porque isso é ordem do Bombril [superintendente estadual do INCRA]', e isso aí a pessoa acaba pensando: 'eles tem poder, tem a força, já batero em muitas famílias, empurraro muitas famílias pra fora daqui...’ eu não tô dizendo o MST, eu tô dizendo a sem-vergonhice, do câncer que tá no MST, que são essas pessoas [...]" (Sr. Arthur, entrevista).

Os assentados pontuam que essa proximidade do MST com o poder executivo um dia vai acabar, com o final do mandato do atual Presidente da República, e que tanto assentados quanto a liderança vão precisar estar afinados, pois vão precisar um do outro pra avançar na luta:

\footnotetext{
"Eles teriam que ouvir a base, entendeu, e que forma que... porque saindo esse governo a coisa vai pegar, aí eles vão precisar do povo, eles estão esquecendo disso. Enquanto tá Lula, tá muito bom, entendeu, porque o Lula faz seus arranjos daqui, seus arranjos dali, então...mas se cair um governo de direita, eles pode esperar que eles vão precisar do povo, a direção vai precisar do povo e o povo vai precisar de direção." (Sr. Ivan, entrevista).
}

No entanto, cabe pontuar que os técnicos contratados pelo INCRA, por sua vez, têm sido escolhidos entre técnicos de esquerda, com alguma proximidade com o ideário do MST. Assim, em algumas situações administrativas, esses técnicos têm contribuído para a construção de um projeto de assentamento conforme a visão e o tipo de atuação do MST, como no caso de não permitir arrendamento, ou incentivar a produção em forma coletiva. 
Os assentados pontuam uma proximidade bastante grande entre esses técnicos estatais e as lideranças do MST, com os primeiros reforçando a ação dos segundos. Na fala de alguns assentados, a proximidade das lideranças com o governo federal é uma das causas do afastamento do MST com as bases, e do surgimento de rupturas.

Devido a isso, a existência de uma relação no mínimo confusa entre os técnicos estatais e a liderança do movimento social não se limita a esse governo federal, mas como têm pontuado vários teóricos, o perfil dos agentes estatais que optam por trabalhar nessa área é o do militante de esquerda, que apresenta uma certa afinidade ideológica com o MST (BRENNEISEIN, 2005; D’INCAO, 2000; ZIMMERMAN, 1994).

A proximidade do Movimento com o governo federal é, na realidade, um problema para o primeiro. O apoio dos técnicos estatais ao projeto coletivista do MST poderia aparentar ser um ganho, mas é contraproducente, pois contamina o movimento social com a lógica técnico-burocrática do Estado, bem como reforça a heteronomia do indivíduo, contribuindo para tirar do sujeito a capacidade de discussão, reflexão e decisão de seus próprios caminhos.

O acesso a recursos públicos, por parte do MST, que possibilitaram a contratação de técnicos por parte do Movimento, em vez de positiva, ao possibilitar a contratação de alguém que "entende" os assentados, pois é um "orgânico", também contribuem para que o movimento social assuma uma lógica técnico-burocrática e produtivista, pois ao assumir uma tarefa que antes era estatal, assume também uma racionalidade típica do Estado - uma racionalidade instrumental. Caume (2002) vai pontuar que essa atitude contribui para produzir uma cisão interna ao Movimento, pois cria uma elite detentora de um "saberpoder", decorrente de uma atividade técnico-científica, que os legitima a um uso maior da 
palavra, em contraposição a uma parte significativa de militantes do movimento social, que passa a assumir uma posição secundária e subalterna.

Cabe frisar que a atuação estatal também é pontuada pela ambiguidade, em função de projetos positivos que este governo estaria executando nos assentamentos, como a biblioteca e principalmente a $\mathrm{CONAB}$, pois segundo vários assentados têm sido muito positivo o PAA (Programa de Aquisição de Alimentos), programa conjunto do MDA e do MDS.

Segundo esse projeto, todo produtor rural tem uma cota de produção que ele pode vender para o governo, que utiliza esses alimentos para a formação do estoque regulador, para merenda escolar dos municípios participantes, ou para o repasse para entidades da sociedade civil que tem convênio com o governo (creches, asilos, hospitais, ONGs e outras entidades filantrópicas). No caso do assentamento Sepé Tiaraju, a modalidade do PAA em vigor é esta última, denominada de "doação simultânea", sendo que entidades da região recebem os alimentos.

Conforme pontuamos anteriormente, os assentados do Sepé têm um volume bastante grande de produção, e a solicitação deles com relação ao PAA/CONAB é de aumento da cota de produção, que hoje está em torno de $\mathrm{R} \$ 3000,00 /$ ano, sendo que quase todos os assentados já atingiram essa cota.

Esse programa é entendido também como uma forma de gerar renda de forma contínua, como uma garantia de compra da produção, o que estimula a produção e tem como decorrência o aumento da qualidade de vida no campo: 
"Se o governo, neste projeto da CONAB, ele aumentar o projeto da CONAB pra cinco mil, cada produtor vai ter no ano, $\mathrm{R} \$ 400,00$ mensal, quatrocentos e pouquinho, pra ele poder se manter, e produzir tranquilo, [...] então ele tem uma renda garantida de $\mathrm{R} \$ 400,00$, que essa renda de quatrocentos real não é muito, mas já dá pra comprar o básico, porque aí você tem uma mandioca, tem umas coisas, dá pra viver, e aí vai corrigindo com a inflação, porque até o ano passado a inflação era controlada, então não defasava tanto. Então se conseguisse fazer essa leitura da pequena produção agrícola, então os assentados da reforma agrária conseguiria ter, no geral, um nível de vida bom [...] ” (Sr. Geraldo, entrevista).

Os assentados, em sua maioria esmagadora, têm uma visão positiva do atual Presidente da República, entendendo que ele tem boas intenções para com os assentados e responsabilizando os agentes estatais pelo fato de não haverem políticas públicas federais adequadas ao assentamento.

Além disso, os assentados pontuam que não são mais tratados como "caso de polícia" por esse governo, mas como "questão social". Nesse sentido, a postura assumida pelo governo federal contribui para diminuir, no imaginário popular, a visão do Sem-terra como associado à violência e à baderna, que é alimentada pela mídia conservadora. 


\subsection{A relação da liderança local do MST com os assentados}

Na atual composição da Diretoria Regional do MST, trinta diretores são assentados no Sepé Tiaraju. Cabe lembrar que são oitenta famílias assentadas no Sepé, de onde se conclui que uma porcentagem grande está bastante envolvida com o Movimento, compondo inclusive sua liderança regional.

Segundo um dos diretores regionais do MST, assentado no Sepé, esse assentamento foi organizado buscando-se garantir os seguintes princípios do Movimento: agroecologia, posse coletiva da terra, trabalho direto pelas famílias. No entendimento dessa liderança, um dos pontos mais importantes era garantir a posse coletiva da terra, a fim de quebrar a lógica do capitalismo:

\footnotetext{
“A posse da área é co-le-ti-va [fala com ênfase]. Isso é muito mais que... esse povo fica vomitando revolução, isso é muito mais na prática. Tem contradições? Tem [fala com ênfase]! Porque esse negócio de assentamento é bruto [fala com ênfase]! Trabalhar com gente é bruto [fala com ênfase]! Ainda mais no campo... ce cê... caboclo imaginando sua propriedade, os quatro marcos, entendeu, da cerca dele. Se for essa lógica, nós estamos reproduzindo o capi... reproduzindo a propriedade privada: a terra tem que ser liberta [fala com ênfase]! Por isso que não tem cerca no meu lote. Eu não quero ter cerca no meu lote. Porque representa isso, representa a propriedadona privada lá, que tem um dono, e aqui dentro foi uma luta muito grande para pelo menos garantir esses princípios: não arrendamento, posse coletiva da terra, não produto químico, assentamento baseado na agrofloresta.” (Sr. Vitor, entrevista).
} 
No Sepé Tiaraju, há uma expectativa de que os assentados se mantenham organizados para plantar, de forma coletiva, mais de $50 \%$ do assentamento como Agrofloresta (CONCRAB, 2004). Pode-se perceber que a produção agroecológica tem sido a grande tônica do discurso do MST desde o $4^{\circ}$ Congresso, o que foi reforçado neste último Congresso em Brasília, e essa ênfase aplica-se também ao Sepé. No caso desse assentamento, cada um dos beneficiários teve que assinar um TAC - Termo de Ajustamento de Conduta elaborado pelo Ministério Público Estadual e pelo INCRA, no qual se compromete a produzir somente de forma agroecológica, pois se trata de uma área com mananciais.

Quanto ao trabalho de agricultor, a ênfase dada pelo MST e pelos técnicos presentes na área é para a constituição de grupos de produção coletiva. Assim, o recorte da área foi feito a fim de facilitar o trabalho coletivo, o mesmo acontecendo com as discussões de produção. De acordo com o MST, no Sepé “avançou-se nas discussões de planificação das ações econômicas, pela compreensão que o assentamento deve ser pensado coletivamente (este é um dos pontos que precisa ser trabalhado para ser fortalecido)." (CONCRAB, 2004, p.35).

Pode-se perceber uma preocupação da liderança do MST, no caso do Sepé, em mostrar para quem é de fora que o assentamento dá certo, que produz, que é bom para a sociedade (CONCRAB, 2004). Assim, no caso do Sepé, os aspectos "ligados ao plano de produção são vitais para garantir os princípios constitutivos da proposta" (CONCRAB, 2004, p. 35). A proposta de trabalho coletivo está baseada nas questões produtivas ligadas à agricultura, e, da mesma forma que o preconizado nos documentos oficiais, a atuação da 
liderança regional demonstra certa preocupação em fixar o homem no campo e garantir que ele produza.

A liderança do MST, que apresenta maior clareza, capacidade de análise política e de avaliação estrutural, possui uma preocupação com o assentado acabar na cidade de novo, com ele ser novamente expulso:

\footnotetext{
"Eu creio que pra todo mundo que tá aqui, mudou muito demais, mudou muita coisa. Seria uma pena amanhã, daqui a cinco anos, dez anos, cê vê o cara na cidade de novo. Porque esse processo que passou e o que a gente tem hoje não é pouca coisa." (Sr. Geraldo, entrevista).
}

Também demonstram bastante apego e capacidade de sacrifício em favor da luta pela terra e por mudanças na sociedade brasileira. Os assentados contam que quando houve o leilão para a venda das terras da usina, e que nenhum interessado apareceu, o que foi fruto do trabalho político do MST, as principais lideranças até choraram de emoção. (Diário de Campo, p. 45). Muitos assentados da militância, em cargo de direção ou não, se sacrificam pelo bem coletivo e para que mais pessoas se tornem assentados como eles, abrindo mão inclusive de certas vantagens ou do próprio desenvolvimento econômico. Um desses exemplos é a Dona Ana, única assentada a continuar ativa no Coletivo de Saúde, e que muitas vezes abre mão de sua vida pessoal e da produção em seu lote para cuidar da saúde dos outros assentados. Nas palavras do Sr. Marco, que é membro da direção regional,

"Até as vezes você deixa a desejar na produção, mas... nem que você perde dias aí ocupando o INCRA, ou em outra luta, ajudando outros 
companheiros, então as vezes você fica um pouco atrás... Eu mesmo fiquei um ano e meio aqui, quase dois anos fora do meu lote, que eu tô correndo agora que é pra eu recuperar esse tempo, mas... Trabalhando de outra forma, né, as vezes não é bem reconhecido isso, porque as vezes, depois que você conquista uma terra, um monte de companheiro que sai ai na luta, quem fica as vezes não reconhece isso. Tem hora que tem que ir mesmo. [...].”(Sr. Marco, entrevista)

Quanto à relação do MST com os assentados, essa se dá de uma forma tensa e intensa. Há uma proximidade e um vínculo muito grande dos assentados em geral com o movimento em tela, pois além da participação de um número significativo de assentados na Diretoria Regional do MST, há outros que integram outras instâncias estaduais e nacionais, como a Direção Estadual e o Coletivo Nacional de Educação.

Além disso, os assentados do Sepé têm um sentimento de pertença e de identidade com o MST. Eles usam o termo 'militantes' para se referir àqueles que têm cargo de direção no Movimento, mas por vezes aplicam o termo a si mesmos, pois participaram da luta e consideram o MST como sua organização.

A maioria dos militantes com cargos diretivos no MST reside no núcleo Paulo Freire. Eles se juntaram em um núcleo só, a fim de formarem um coletivo com os lotes individuais. A formação desse coletivo, chamado de Miraflores, tinha por objetivo despertar os assentados para a necessidade, a importância e a factibilidade do trabalho associativo. Os militantes também se propuseram a construir casas de tijolo de adobe, formando o grupo 'alternativo' de construção das casas. 
Segundo os militantes, terem ficado no mesmo núcleo se deve não só à oportunidade de trabalhar em conjunto para servirem de exemplo, mas também ao fato de que há uma falta de compreensão dos outros assentados, "não-militantes", da necessidade deles saírem "para fora" a fim de realizar o trabalho de militância. Alguns desses assentados em cargos de liderança no MST ainda não se mudaram para o assentamento.

Dona Ana falou de seus projetos junto com a associação que eles estão montando, a Miraflores. Disse que é uma associação de militantes, que os assentados disseram que o lote dos militantes ia ficar no mato, que eles saiam para viajar e que eles não iam trabalhar pra eles não, então os militantes se juntaram e vão mostrar na prática que produzem bem (Diário de Campo, p. 44; 13/11/2006).

A criação de um subgrupo como o Miraflores, além de separar a liderança da base, acaba por criar duas categorias diferentes de assentados: os ligados à direção e que por isso seriam mais ouvidos e respeitados pela liderança, segundo o entendimento de boa parte dos assentados; e os de segunda categoria, que seriam menos considerados pelos líderes, sendo inclusive prejudicados por isso:

Fomos para o ponto de ônibus, e o Gilson começou a contar que quem é da direção ou da militância, quem tem uma atuação mais política tem mais 'regalias', o mesmo acontecendo com quem tá mais ligado a eles: “A palavra e a opinião destes é mais levada em conta, a opinião de quem não é ligado a este grupo é descartada de cara, sem ser considerada. Isso nunca aconteceu comigo, mas já vi acontecer com várias pessoas. Hoje é 
ele, amanhã sou eu. E fica um medo de ser excluído, porque qualquer coisa que você falar você pode ser punido. A Direção impõe as coisas, diz: vai ser assim ou então não vai ser nada, isso é sinal de que já se perdeu o respeito pela Direção aqui dentro.” (Diário de Campo, p. 46, 13/11/2006).

Outro exemplo dos comentários nesse sentido ocorreu quando dois assentados, sem autorização ou conhecimento das outras setenta e oito famílias, ligaram a energia elétrica comum (de todo o assentamento) para usar a bomba de água e tirarem água do poço por um mês inteiro. No final do mês, a presidência do assentamento foi surpreendida por uma conta de luz com valores exorbitantes, descobrindo então o uso não discutido ou autorizado da bomba d'água. Foi chamada uma reunião da Coordenação para discutir o uso privado da luz comum, reunião esta da qual a liderança regional do MST participou. Após essa reunião, correu um boato no assentamento de que o próprio MST ia pagar a conta de luz, porque os assentados que fizeram o gasto eram ligados ao coletivo dos militantes, e que "lá no assentamento tinha dois pesos e duas medidas". (Diário de Campo, p. 134, 09/05/2007).

Além disso, a opção por ficar separado também serviu para fomentar comentários de que a liderança tinha "regalias", pois em função de fazer os trabalhos de mobilização fora do assentamento, a liderança trazia jovens acampados para fazer as atividades em seus lotes, gerando comentários junto à base.

No final das contas, a constituição do grupo Miraflores foi uma experiência frustrada, que teve o efeito contrário, justamente o de confirmar a impressão de parte dos assentados que os militantes não trabalham, e que o trabalho coletivo não dá certo. 
O grupo de construção "alternativo", formado por esses mesmos militantes, e que iria construir casas de adobe em vez de usar tijolo convencional, com o intuído de colocar em prática uma alternativa de construção que fugisse da construção de mercado e que retomasse a cultura camponesa, além de com os mesmos recursos proporcionar uma casa maior, também não se concretizou, em função da dedicação dos militantes aos trabalhos externos. Assim, dos coletivos de construção de moradia, o que menos funcionou foi o constituído pela liderança, tendo-se em vista que os outros coletivos, bem ou mal, construíram as casas, ou parte delas. Um dos militantes "contou-me sobre as casas, que ia ter uma reunião sobre o grupo do adobe, que não estava fazendo as casas, então iam desmanchar o grupo e cada um ia fazer sua casa como desse." (Diário de Campo, p. 192, 16/05/2008).

Cabe pontuar que essa opção está em dissonância com o primeiro princípio organizativo do MST, que é a vinculação permanente com as massas (STÉDILE, 1997). No caderno "O que levar em conta na organização do assentamento" (ANCA, 2002, p. 26), publicação interna dirigida aos militantes, há a orientação para que as lideranças não fiquem no mesmo grupo, mas se dividam pelos núcleos do assentamento:

Devemos ter atenção para que as lideranças não finquem todas no mesmo grupo (identificação pela política, pelo projeto político). Infelizmente deveremos explicar para estas pessoas a importância de se ter no mínimo uma liderança em cada núcleo base, buscando consolidar estes espaços de participação e de vivência, sendo os núcleos a base da estrutura orgânica no futuro assentamento. 
Outro ponto que gera tensão na relação entre liderança regional e os assentados é o entendimento destes últimos de que a liderança teria assumido uma postura autoritária para com eles. Esse autoritarismo se manifestaria em ocasiões de divergência de pensamento ou opinião entre base e liderança, com esta última tentando impor sua visão de mundo ou sua opinião acerca da condução da produção, da luta ou da forma de organização do assentamento.

O longo trecho que se segue, depoimento de um assentado que se afastou da direção regional do MST, dá a idéia da tensão existente na relação de parte dos assentados com essa liderança, bem como do autoritarismo que esses assentados reportam como presente na atuação da direção regional do MST:

“Eu não acho certo, eu não acho legal, porque eles ( liderança regional) oprimem as pessoas, as famílias. Eles... quando aqui era... antes de ser assentamento, de virar lei mesmo, da gente assinar o SIPRA da gente, muitas famílias foram embora daqui por ameaça deles, porque tinha que ser do jeito que eles queriam. Então muitas famílias que não podiam ter ido embora, ficou muitos anos debaixo da lona, perdeu o tempo deles, e eu sou triste com a direção do MST aqui, aqui na região. Então... existe região que o MST coordena assentamento, que a gente vai lá, não vou indicar nenhuma pra você, que a gente vai lá fazer visita e dá vontade de ficar lá, a harmonia que tem entre assentado e MST. Eu acho que... agora a nossa aqui eu não sei... eu posso declarar com toda as letras porque eu já tive... já tive algum saber, (...) e a pessoa que fez a sem-vergonhice confirmou na reunião de coordenação, que ela fez coisa errada, então essa coisa errada, nos tratou como objeto de comércio pra ele, então eu fiquei 
triste com isso. Usar a pessoa pra ser objeto de projeto para beneficiar ele. E não sou eu que venho a tornar isso público, mas o assentamento inteirinho sabe disso, o assentamento sabe que eles fizeram isso daí e eles mesmos provô em reunião de coordenação. Então, pra mim o MST aqui dentro, ele é o MST do meu país inteirinho, agora as pessoas que tá dentro do MST, que eu não acho com competência para hastear essa bandeira. Eu vou ser sincero a falar pra você, vai chegar um dia em que nós não qué nem eles aqui dentro mais. Ou eles trocam... cê sabe que você vai enchendo com a pessoa, olhando praquela pessoa e sabendo que não existe amor pela luta, mas existe sim ele ser líder de uma força, e de repente essa força ele tratar a gente como comércio também, um crime inafiançável. (...) Mas quando se trata da luta, de ser humano, acho que devia ser diferente. Eu vou ser sincero com você, pra mim é zero. É dez pela luta, dez pela resistência, dez pelas batalhas, mas comportamento, pra minha pessoa, e tenho certeza que pra dezenas de pessoas aqui, é zero. O comportamento deles pra mim não vale nada, eu não tenho coragem de chamar eles de companheiro. Isso eu já provei pra Lígia, que é a líder do MST aqui (...), porque companheiro não faz ameaça pra ninguém, companheiro aconselha, ajuda, mas não ameaça. E eu não gosto de ameaça, já fui muito ameaçado pela polícia pra poder nóis desistir da luta, fui ameaçado pelo governo, ainda sou ameaçado pela política que o povo chama de política pública, e não a política social coletiva." (Sr. Arthur, entrevista). 
A questão do desejo de controle aparece em um ato falho de uma das lideranças, ao falar sobre a conveniência, para a direção regional do MST, dessa pesquisa ser desenvolvida no assentamento Mario Lago, e não no Sepé-Tiaraju:

Quando estava falando sobre o Mario Lago ser mais organizado segundo os princípios do Movimento (mais orgânico), Lígia disse que 'organizado assim o assentamento não foge do "controle", e se corrigiu, dizendo: “controle é feio, né?, [melhor dizer que] não tem tantos problemas internos". (Diário de Campo, p. 20, 05/09/2006).

Os assentados também se ressentem do fato da liderança não dar atenção ao que eles falam, verbalizando que a direção regional não ouve mais a base:

“[...] o povo tem o direito à palavra, tem o direito de ser ouvido, entendeu, e tem o direito também de falar. Porque nós não tá preso assim... a uma sociedade, entendeu, porque cada um tem o seu objetivo, tem as diferenças, entendeu, e isso deve ser respeitado, que nem o Paulo Freire diz, temos que aprender a viver com as diferenças e as indiferenças. O que está faltando nesses companheiros é um pouco de... sei lá, de humildade no caso, entendeu. Sentar com a base, conversar com a base, ver o que realmente.. que forma a gente pode trabalhar, entendeu, [...], porque o povo se sente... por mais que seja um povo assim... um pouco leigo, mas não são burro, eles são inteligente, entendeu, o próprio Movimento insinaro isso pra nóis, entendeu, reivindicar... eles tem isso com eles, porque eles aprenderam a reivindicar, entendeu, então... quando 
o povo reivindica eles acha que o povo tá errado. Não é bem assim... então tem que... tem que parar pra ouvir, entendeu?" (Sr. Ivan, entrevista)

Uma das características do comportamento autoritário é que tudo deve tornar-se semelhante a ele, nada pode ser divergente ou diferente. A existência do divergente não é tolerada, este acaba por ser negado e deve ser eliminado, tudo deve ser uniformizado e igual.

Ao assumir uma postura autoritária, além de revelar uma insegurança básica frente a uma situação, talvez frente ao fato de o assentamento estar começando a "fugir do controle", a liderança assume uma postura que enfraquece a autoridade interna dos assentados, induzindo a construção de uma relação que tende a enfraquecer o ego e a autonomia dos indivíduos, bem como sua consciência. Isso tem como consequência uma atrofia crescente da capacidade de refletir e questionar, adquirida na própria luta.

A sensação de impotência (ou de pouco poder) - real ou imaginária - frente ao poder possuído por outros, manifestado pelos assentados em relação à direção regional do MST, prejudica o desenvolvimento da capacidade de reflexão e de crítica, inviabilizando o desenvolvimento do pensamento necessário à emancipação e à autonomia, paralisando "os movimentos que impelem ao conhecimento" (ADORNO, 1996, p. 406).

Cumpre lembrar que nessa sociedade, os indivíduos com um ego frágil e um superego externalizado, tendem a construir relações de autoritarismo e submissão, submetendo-se à autoridade ou oprimindo os outros quando ele é que está nesse lugar de poder. Não podemos esquecer que o poder se dá em uma relação, ou seja, o autoritarismo não se dá por obra unilateral da liderança, que os assentados sofrem de forma passiva, mas os assentados reagem a ele de forma não explícita, com conversas paralelas ou pequenas 
sabotagens à atuação da liderança, como pontuam vários autores (BRENNEISEIN, 2002; CAUME, 2002).

Além disso, como os indivíduos têm seu funcionamento, desde a mais tenra idade, moldados por essa lógica autoritária, o comportamento autoritário acaba sendo uma referência, isto é, o indivíduo reage autoritariamente, de uma forma quase reflexa, quando se encontra em uma situação de relação interpessoal onde há divergência. Assim, a postura autoritária não é privilégio somente da liderança, sendo reproduzida, e por vezes demandada, pelos próprios indivíduos em suas relações cotidianas.

Com isso em mente, há que se considerar que, se por um lado, há um certo exagero dos assentados nas críticas com relação ao autoritarismo da liderança, por outro, o que se pode constatar, durante o trabalho de campo, é que há efetivamente uma tendência à reprodução de relações autoritárias, quiçá de forma involuntária, por parte de componentes da liderança em relação aos assentados no Sepé Tiaraju.

Segundo os próprios assentados, inclusive os ligados à direção, há uma relação assimétrica com a liderança do MST, que são assentados como eles. Como já pontuamos, eles reclamam que os que são da militância ou que estão próximos a eles têm alguns privilégios ou regalias, que o restante dos assentados não tem.

Também reclamam que as opiniões de algumas pessoas têm mais valor do que a de outras, ou que eles não podem falar livremente, porque algumas falas e posturas que contenham alguma crítica ao MST são condenadas:

Um dos senhores presentes trouxe a fala de uma senhora do seu núcleo, que doou $\mathrm{R} \$ 40,00$ e na hora da festa não conseguiu comer nada, nem ela nem suas duas filhas, e ela questionou a organização. Uma das lideranças 
do Coletivo de Cultura, um senhor mais idoso, fez mea culpa, disse que eles trabalharam muito, mas que ainda assim houve falhas, mas que eles iriam se corrigindo e melhorando cada vez mais. Essa fala não encontrou eco no resto da liderança do coletivo e do MST presente, que disseram que trabalharam muito, que as pessoas reclamam e não ajudam, que tem se tem que valorizar os pontos positivos e olhar para frente, e não olhar os negativos (...). Ficou-se com a sensação de que era errado reclamar, e o Sr. que colocou a reclamação acabou pedindo desculpas de ter falado aquilo, ficou se justificando dizendo que ele não pensava aquilo, e que ele era representante do núcleo dele, e só falou porque era sua obrigação colocar a fala dos representados (Diário de Campo, p. 26; 06/09/2006, reunião de coletivos no assentamento Mario Lago).

Um exemplo ilustrativo dessa relação próxima e por vezes contraditória, entre assentados e a liderança do MST, foi a ação de bloquear a pista, para reivindicar a ligação da rede de água no assentamento, no mês de abril de 2007. Segundo os assentados que fazem parte da base, eles efetivamente participaram do planejamento e organização da ação, inclusive dando opinião quanto ao que e como deveriam fazer. O objetivo desse protesto para os assentados era o de reivindicar a ligação da rede de água, visto eles já estarem há sete anos no Sepé sem água. Foi com essa intenção que eles foram para a rodovia Abrahão Assed, e já conhecedores de todo o processo e ritual de negociação, esperavam ocupar a pista, que a polícia ou o usineiro ou a municipalidade ligasse para o INCRA, que o Setor de Mediação de Conflitos do INCRA viesse negociar e então eles desocupariam a rodovia mediante algum comprometimento do INCRA com relação à água. 
Já para a liderança regional do MST, o objetivo parecia ser o de participar do Abril Vermelho, objetivo esse explicitado no conteúdo das entrevistas dadas às várias emissoras de televisão e jornais presentes ao protesto, bem com ao fato da militância deter previamente a informação de que o INCRA não viria, posto que todos os funcionários estavam em uma reunião em São Paulo.

Havia um descompasso entre finalidades, e os assentados, que não tinham claro quais os objetivos perseguidos pela liderança, se sentiram muito insatisfeitos com o resultado do protesto, visto que ele foi encerrado após duas horas, sem qualquer tipo de negociação com o INCRA ou demais responsáveis:

Depois de um tempo na pista, lá pras $12 \mathrm{hs} 30$, todo mundo foi chamado para uma assembléia na rotatória e se liberou a pista. [...]. Vitor [liderança do MST, assentado no Sepé] fez um discurso inflamado, dizendo que Lula fala que os usineiros são heróis, heróis são eles que estão há sete anos debaixo da lona e sem água [...]. Falou também que conversando com a coordenação, chegaram à conclusão de que o objetivo já tinha sido atingido. Nesse momento, no casal na minha frente, a mulher virou para o marido: '- Atingiu o objetivo o que?, o INCRA nem veio', ao que o marido assentiu com a cabeça (Diário de Campo, p. 126; 25/04/2007).

Esse evento também demonstra um utilitarismo de algumas das lideranças na relação com os assentados. Após esse protesto, vários assentados decidiram não participar mais de mobilizações do MST, pois tinham a vaga sensação de que foram usados. Diante desse evento, é possível afirmar que se as ações da liderança dentro do Sepé Tiaraju não 
são regidas somente por uma razão instrumental, como critica Navarro (2002), também não escapam completamente dessa lógica, e por vezes se deixam engolir por ela, como demonstra o exemplo acima, a utilização para a liderança com fins maiores (Abril Vermelho), enquanto a base achava que era por água. Essa ação foi discutida pelos assentados durante várias reuniões da Coordenação do assentamento, inclusive com a participação da liderança do Movimento, que foi duramente cobrada e confrontada em pelo menos uma dessas reuniões, na qual o pesquisador estava presente.

Do mesmo modo, houve divergências entre liderança e assentados no que diz respeito aos encaminhamentos que deveriam ser tomados em função da não legalização da Agro-Sepé, após três anos do processo iniciado junto ao cartório da cidade de Cravinhos, que também revelam aspectos interessantes da relação entre assentados e lideranças. $\mathrm{Na}$ reunião de coordenação do assentamento chamada por esta para discutir o assunto, no qual estavam presentes poucos assentados, os mesmos de sempre e mais uma meia dúzia, compareceu também, como representante da liderança regional do MST, o advogado voluntário do Movimento (Diário de Campo, p. 146, 27/06/2007).

$\mathrm{Na}$ ocasião, os assentados começaram por discutir o fato de que já estavam na terra há três anos sem regularizar a associação, e que o INCRA teria dito que ia ajudar, e não deu em nada. Posteriormente, o então advogado do Movimento teria assumido o trabalho para si, e concluiu que o cartorário tinha que registrar a associação da forma como estava, sendo que o cartorário se recusava, pois havia erros. O então advogado do MST teria se recusado a fazer as mudanças demandadas pelo cartório, pontuando que era uma questão política, pois se fosse associação de fazendeiros, o cartorário não questionaria nada. Assim, a associação não foi regularizada. 
Na reunião, após muitas discussões sobre como deveriam encaminhar o registro da Agro-Sepé, um dos assentados lembrou que o promotor de Ribeirão Preto disse que estava à disposição para ajudá-los com questões jurídicas que eles tivessem necessidade. Outros assentados sugeriram então formar uma comissão de assentados, para ir até o cartório pegar uma cópia da documentação, estudá-la, e então ir conversar com o promotor, para ver se alguma coisa poderia ser feita para resolver o imbróglio do registro da Agro-Sepé.

O novo advogado voluntário do MST, presente na reunião, tentou dissuadir os assentados de formar a comissão para ir conversar com o promotor, alegando que o momento era de "acumular forças". Considerando que a pauta da reunião havia sido informada ao MST com antecedência, e que a liderança tinha sido oficialmente convidada a participar da mesma, a intervenção do representante enviado pela direção regional do Movimento chama a atenção por dois aspectos principais:

1) primeiro, interviu no sentido de desestimular uma tentativa de ação coletiva e autônoma dos assentados, que na pior das hipóteses iria colocá-los a par da situação em que estava a entidade coletiva que estão tentando montar;

2) segundo, a ausência de uma liderança efetiva do MST na reunião de coordenação, que mandou como preposto alguém recém iniciado na atividade, e com pouco ou nenhum poder de decisão, o que demonstra uma certa desvalorização, da própria liderança, dos espaços coletivos de discussão política do assentamento.

Essa atuação, de certa maneira, desestimulou a participação ativa e autônoma dos indivíduos, e em vez de uma efetiva participação intelectual, induziu-se a assunção de uma posição passiva, que remete à mesma posição que o indivíduo tinha antes de participar da luta social. 
Nesse sentido, de uma lógica contestatória do "já dado", da mentalidade reinante, que é incentivada no período do acampamento, o Movimento passa a reforçar mecanismos presentes no que Adorno vai denominar de mentalidade do ticket, em algumas de suas atuações no assentamento.

A mentalidade do ticket se caracteriza pelo pensamento em bloco, isto é, as reflexões são substituídas por "pacotes fechados" de pensamento, de opiniões socialmente sancionadas. O indivíduo adere a um desses blocos de pensamento, como quem compra uma cesta de produtos básicos, no qual ao eleger um dos tipos possíveis disponíveis no mercado, você automaticamente adquire todos os produtos pertencentes àquela cesta.

Esse pensamento extremamente simplificado demanda uma aderência em bloco ao que é sancionado por aquele grupo social, e dispensa a reflexão e o esforço ativo exigido para se pensar de forma efetiva e crítica, sendo, nesse sentido, muito mais fácil e preguiçoso.

Conforme pontuam Adorno e Horkheimer (1985), ao desestimular o pensamento e a reflexão autônomos, muitos grupos de esquerda assumem uma postura de reforçar a mentalidade do ticket, que ocorre de forma generalizada em nossas sociedades capitalistas modernas. Esses grupos induzem a um pensamento simplificado e por categorias, admitindo somente uma posição como politicamente possível, desmerecendo ou desconsiderando qualquer discordância, que é entendida como estar contra a causa ou não ter consciência.

Zimmerman (1994) conclui em seu trabalho sobre os desafios da organização interna de um assentamento que a especialização da liderança, que passa a ser detentora de um saber diferenciado sobre o fazer político, em detrimento da base, acaba por reservar 
para as lideranças a legitimidade da tarefa do pensar, deixando para a base as atividades mais práticas, desprezando a experiência e os conhecimentos dos assentados.

Nos casos acima vistos, podemos perceber que certas posturas ou falas que indiquem uma direção diferente da colocada pela liderança, ou que contenha alguma crítica à atuação do Movimento, por menor que seja, são condenadas, como no caso da crítica à organização da festa. A tarefa de pensar em termos de ação política e de decidir os caminhos a serem trilhados também acabam por ser reservados à direção do Movimento, como vimos no caso do protesto na rodovia e na tentativa de desestimular a formação de uma comissão de assentados para conversar com o promotor.

A mentalidade do ticket, com sua lógica afim ao produtivismo e à divisão de trabalho, sanciona somente posições pré-determinadas como corretas e induz os indivíduos a aderiram a essas posições em bloco, também reforça a divisão do trabalho e a especialização, ao reservar para um "elite intelectual" a tarefa de pensar pelo conjunto e definir as posições e idéias "corretas", que devem ser assumidas por aqueles que têm consciência e que querem ser aceitos como parte do grupo.

Assim, qualquer discordância ou questionamento, a tentativa de alguns assentados de concordar com algumas coisas e discordar de outras, que indica a intenção de refletir de forma não pré-moldada e não conformista, é entendida, de forma simplista, como uma oposição ao Movimento como um todo e, nesse sentido, simplifica-se a própria contraposição aos questionamentos, colocando-se naquele que questiona um rótulo de inimigo da luta, ou de oportunista, ou de pouco consciente.

Nesse sentido, o Movimento contribui para a reafirmação do mundo administrado no espaço do assentamento, ao só aceitar como correto uma posição já pré-formada, exterior aos indivíduos, e tentar impor essa posição ao conjunto dos assentados. Segundo 
Adorno (1986d, 1992), essa postura engessa o movimento dialético, reforça o positivismo e o pragmatismo, e impedem o avanço da história.

Outrossim, contribuem para que os assentados voltem a assumir uma postura de mera repetição e de equivalência ao sempre idêntico. A capacidade de pensar dos indivíduos é desestimulada, levando a um recrudescimento da reificação induzida pela sociedade, e atentando contra a autonomia e emancipação dos indivíduos. Lembramos que os indivíduos poderem pensar e se expressar de forma não tutelada é condição para a verdadeira democracia.

Assim, há um risco do Movimento, buscando fazer o melhor, reforçar o funcionamento psicológico heterônomo dos indivíduos, ao buscar fazer valer no assentamento as suas posições a todo custo, inclusive se colocando no lugar do ideal de ego do indivíduo, seja com idéias, seja com pessoas. O que num primeiro momento pode parecer ter dado resultado positivo, por gerar algum tipo de união, pode gerar problemas a longo prazo, como narcisismo e paranóia (LASTORIA, 2004).

Cabe pontuar que o fato de sancionar um pensamento, condenar o divergente, associado à progressiva perda de poder de fato após o assentamento (não poder mais excluir sem a intervenção estatal), contribui para um enfraquecimento da participação dos assentados em atividades promovidas pelo MST.

Assim, o fato da liderança tentar se manter no assentamento de forma autoritária, a qualquer custo, reproduz a mentalidade do ticket reinante na sociedade capitalista, e contribui para que os indivíduos voltem a um padrão anterior de comportamento, ou seja, que se adaptem com o padrão acrítico e conformista com os quais eles estavam acostumados antes de entrar para o Movimento. Nesse sentido, a liderança acaba por 
contribuir com a reificação dos indivíduos, com o declínio da experiência, e com a entrada da lógica de dominação do mundo administrado no assentamento.

Essa posição de desestimular o pensamento autônomo e a ação não tutelada, bem como sancionar somente uma posição como politicamente correta, posição essa que os indivíduos devem assumir se quiserem ser considerados como "conscientes" e "a favor da luta", revela uma compreensão acerca desses assentados que os colocam em uma posição de minoridade e de inferioridade frente a um grupo de dirigentes politicamente esclarecidos, bem como dá a entender que se os assentados não forem conduzidos e induzidos a assumirem essas posições, não terão capacidade de chegar ao desenvolvimento de posições positivas através de sua própria reflexão coletiva.

Há que se rememorar a consideração de Adorno de que, em alguns movimentos de esquerda, se gasta mais energia para lidar com a liderança do que para lidar com os adversários, tendo-se em vista que a direção de tais movimentos induz à submissão e os participantes acabam por temê-los.

Por outro lado, o que se pôde perceber no assentamento, é que mesmo na relação com a liderança, os assentados se recusam a renunciar o pequeno espaço de autodeterminação que conseguiram, e a independência relativa de seu pensamento, com o direito de expressarem o que pensam. Na reunião acima citada, apesar das considerações do advogado do MST, os assentados formaram a comissão e combinaram o dia para ir ao cartório da cidade de Cravinhos.

Cabem alguns comentários sobre a relação entre o Movimento e o INCRA dentro do assentamento. Como já pontuamos acima, na época do acampamento, o "gerenciamento" do grupo de acampados era realizado exclusivamente pela liderança do MST, que organizava o assentamento, sancionava a entrada dos indivíduos para se tornarem 
acampados, conduzia o processo de construção das regras e zelava pela aplicação das mesmas. Com a atuação do INCRA no assentamento, houve um impacto na relação dos assentados com o movimento social, que passou a se dar em novas bases. Os agora assentados devem prestar contas de suas ações para o INCRA, e as regras de convivência e comportamento impostas por este passam a ter um poder maior do que aquelas consensuadas na época de acampamento, tendo-se em vista que é o INCRA que passa a ter o poder de decidir quem continua como assentado e quem será excluído. Nesse sentido, o MST perde bastante o seu poder de influência dentro do assentamento.

Além disso, a delegação de tarefas do poder público para o movimento social, que num primeiro momento parece compensar a diminuição do poder de influência do Movimento junto ao grupo de assentados, acaba por prejudicar mais ainda a inserção do MST dentro do assentamento. O MST regional é hoje o administrador dos recursos da CONAB para o assentamento Sepé Tiaraju. Isso ocorreu em função da Agro-Sepé não estar regulamentada ainda. O primeiro inconveniente que isso causa ao Movimento, e do qual ele aparentemente não se apercebe, é a interpretação, feita por alguns assentados, de que o Movimento não quer que a associação se estruture realmente, para manter o controle sobre a administração dos recursos dos assentados.

O segundo inconveniente que tal responsabilidade causa, é que o Movimento passa a administrar um programa do governo federal dentro do assentamento, programa este obviamente organizado segundo a lógica estatal. As dificuldades que isso causa, ao colocar o MST na posição de administrador, podem ser percebidas na situação abaixo, de pagamento de produtos já entregues: 
Quando íamos entrar no lote, chegou a Vânia (militante do MST) para conversar com o Ivan.

Afastei-me um pouco, e aí a Vânia disse para o Ivan: 'tenho duas más noticias. A primeira é que por causa do feriado de $5^{\text {a }}$ feira, o cheque da CONAB não veio, não caiu, cê sabe como é essas coisas de governo, tem feriado e eles não trabalham' [sendo que o governo federal trabalhou na sexta], 'então não vai dar pra pagar o seus $\mathrm{R} \$ 60,00$ hoje. E a segunda má notícia é que nós (MST) estamos indo pra Brasília na semana que vem, então só na outra segunda pra te pagar’.

Ivan ficou visivelmente chateado, e reclamou: 'Em que situação vocês me colocam!'

Vânia disse: 'Em que situação estou eu, tendo que passar de casa em casa para explicar isso.'

Ivan ficou bem bravo, mas disse 'fazer o que, né.' Vânia disse que na outra semana traria os $R \$ 120,00, R \$ 60,00$ de uma semana e $R \$ 60,00$ da outra, ao que Ivan respondeu: 'paciência, né'. Vânia perguntou se Ivan ia pra Brasília, ele disse que não. Eles se despediram, e ele estava visivelmente transtornado.

Perguntei o que tinha acontecido, e ele me contou que estava contando com o dinheiro que ia receber, e 'agora esse povo vai pra Brasília e eu vou ficar sem receber'. Disse que eles eram uns 'folgados, porque estão com o deles garantido, e não se importam com a gente. E ainda me pergunta se eu vou pra Brasília! Cê acha, com que dinheiro?' (Diário de Campo, p. 153, 05/06/2007). 
O MST passa a ser responsabilizado por falhas que antes eram atribuídas à administração pública. Retomando a questão da racionalidade instrumental, a proximidade com o Estado e sua racionalidade faz com que o MST se contamine por essa lógica. Assim, o movimento social, ao realizar as tarefas técnicas que antes eram reservadas ao governo federal, também contribui com a entrada e o fortalecimento da racionalidade instrumental dentro do espaço do assentamento.

A assunção do MST de tarefas técnicas também contribui para criar, dentro do Movimento, uma "elite" diferenciada e especializada. O fato de alguns participantes do MST ocuparem o lugar de quem detém um conhecimento político ou técnico-científico que deve ser "passado" para os outros, tem uma série de decorrências.

Primeiro, implica que este possui um conhecimento sobre o que é certo ou errado, legitimado pelo governo federal (que lhe delegou aquela tarefa ou paga o seu salário), o que legitima situações autoritárias, contribui para um aprofundamento das assimetrias e para minar os espaços de discussão política, cuja existência pressupõe, como pontua Rouanet (1985), uma igualdade de condições de participação no processo político e a liberdade de participar do processo argumentativo e de propor e contestar normas, bem como uma ausência de coação externa.

Segundo, agravam um sentido de ordenamento e normatização (e matematização) das relações, pois aqueles que detêm o saber já sabem de antemão onde os assentados devem chegar. A análise feita pela liderança do Movimento, bem como a escolha política ou de projeto de trabalho sancionada pela direção ou pelos técnicos a ela ligados é entendida como a única opção correta, a qual inevitavelmente se chegará desde que se trilhe o caminho certo. Nesse aspecto, tal postura demonstra uma afinidade com o esclarecimento, com seu saber técnico-científico positivista, cujo caráter é eminentemente 
dominador e totalitário, ou seja, os resultados dos processos estão dados previamente, basta os homens se adaptarem a eles.

Os assentados pontuam com clareza a existência de uma relação próxima do MST com o governo, e analisam muitas das atuações conjuntas como uma forma de ambos tentarem "controlar sua vida", ou seja, normatizar a vida social e pessoal do assentado, procurando ordenar, predizer e controlar os comportamentos, os pensamentos e os fenômenos sociais que ocorrem no espaço do assentamento.

Efetivamente, com a proximidade do INCRA com o MST, proximidade esta inclusive político-ideológica, em alguns momentos, a atuação dessas duas instituições acaba por ser complementar ou por se reforçarem, o que tem como decorrência uma visão dos assentados de que é o Movimento que está tentando controlar a sua vida, usando a atuação do governo federal para isso.

Além disso, a proximidade com o INCRA e o recebimento de recursos deste, faz com que a liderança do Movimento seja vista por parte dos assentados como "melhor de vida", ou seja, como uma espécie de elite que está recebendo recursos e tendo uma vida tranquila, usando para isso o fato de serem líderes do MST:

“A coordenação é isso... o coordenamento é isso: ali cê abraça um e dá as costas pro outro. [...] É assim: quando eles andava descalço, eles era uma coisa. Eu não tô falando da luta, tô falando dos soldado. Quando eles andava descalço, era 'oi companheiro' daqui, 'oi companheiro' de lá. Hoje eles andam tudo calçado de pneu, cada um com o seu... entendeu, as veiz até dá as costa pra gente.” (Sr. Rogério, entrevista) 
Nesse sentido, é interessante a fala de uma das lideranças, contando a diferença entre se fazer o trabalho de base hoje em relação ao início. Como ele pontua, o trabalho de militância não é fácil, mesmo hoje, mas avançou bastante em relação à grande dificuldade do início, quando se passava fome:

"No passado, porque hoje tamo assim... vamo dizer... um pouco de regalia, porque no passado, toda militância fazia trabalho a pé, fazendo panfletagem casa por casa, e marcando os horários de reunião. Isso eu participei muito disso daí no passado. A militância, a dificuldade era muito grande pra se fazer o trabalho de massificação, muitas vezes até fome passava, catando latinha pra tentar sobreviver na cidade onde a gente chegava, porque nem conhecido dentro da cidade não era, então... fazia de casa em casa a panfletagem, as vezes saia de dois/três de rua em rua, passando horário de comida, ou as vezes que chegava no local onde dormia não tinha alimento, então foi um momento bastante difícil. E que hoje, as veiz ainda tem um pouco de dificuldade, mas disso daí não passá mais, mais ainda passa bastante dificuldade, até como locomover... Principalmente aqui na regional nós tamos conseguindo alguma condução, mas mesmo assim não tem jeito ainda pra todas militância fazer os trabalhos." (Sr. Angelo, entrevista).

De fato, a proximidade com o INCRA (e com os técnicos estatais) leva a situações que podem até ter uma explicação fácil, mas que alimentam as desconfianças e os comentários maldosos de assentados sobre a liderança regional do MST estar obtendo ganhos pessoais. Entre essas situações, está o fato de que a liderança regional do MST 
possuía, à sua disposição, um carro do INCRA, que portava inclusive o logotipo da instituição nas portas (Diário de Campo, p. 22).

Se por um lado os assentados reclamam de algumas posturas do MST, por outro vivem demandando uma presença maior da liderança ali dentro. Muitos dos embates entre liderança e assentados têm relação com a presença pequena da liderança ali dentro, segundo alguns assentados. Assim se coloca o Sr. Arthur em uma reunião onde foi discutida a ajuda do INCRA para eles finalizarem o processo de registro da Agro-Sepé, e um advogado do MST foi contra a ajuda oferecida, pois eles eram do movimento social e tinham que se organizar ali dentro:

- Isso tá uma falação que não tem resultado. Por exemplo, o fechamento da pista, que nóis fez enquanto Movimento. Cadê o resultado? Nóis ficamo como palhaço. É claro que o Movimento é nosso espaço de nossas 'reidivincações', mas cadê o Movimento? Então Pereira [advogado do MST], eu queria pedi procê, como do Movimento, pra levar pra eles essa fala, que nóis qué eles mais aqui dentro, porque se eles diz que é um órgão que tá no meio da gente, [aponta o peito, a barriga, fazendo referência ao corpo], cadê esse órgão, meu Deus do céu, que a gente não vê por aqui? (Diário de Campo, p. 165; 27/06/2007).

Com o início dos conflitos dentro do assentamento, em especial entre liderança e base, há uma tentativa inicial dos assentados de modificar alguns aspectos do MST, ao considerarem que o Movimento era feito pela base e que, portanto, tinha que ser 
modificado por ela. Essas tentativas foram rechaçadas pela direção, o que causou vários constrangimentos de parte a parte (Diário de Campo, p. 20).

Cabe pontuar que, como analisa Adorno, nesta sociedade, a força de um indivíduo frente ao grupo, para mudá-lo ou para fazer ouvir o seu desejo, é praticamente nula, e isto já é um sinal da participação alienada nesse grupo (HORKHEIMER; ADORNO, 1973).

Como já pontuamos, os assentados se sentem como sendo MST também, o que lhes coloca frente a uma posição conflitiva, dividindo-se entre o desejo de fazer a crítica, mas sem saber como, para não prejudicar o Movimento do qual eles são uma parte:

\footnotetext{
“Então, pra mim o MST aqui dentro, ele é o MST do meu país inteirinho, agora as pessoas que tá dentro do MST, que eu não acho com competência para hastear essa bandeira. [...] Mas você vai fazer o que? Se você denunciar publicamente, você vai fazer outras pessoas sofrê, porque através desses fraudadores, a luta tem que continuar. Por exemplo, dentro do corpo de uma boa pessoa, mas tem um câncer. Tem um câncer dentro do corpo de uma boa pessoa. Assim, dentro do MST... aliás, em todo lugar tem esse tipo de pessoa, até dentro da igreja..." (Sr. Arthur, entrevista).
}

Os assentados são contundentes ao afirmar que eles também são MST, que romperam com a direção regional, e não com o Movimento:

"Então eu num... num acredito nessa de, como se diz, é... ser um ditador, entendeu, nunca... desde a cidade nunca gostei disso, de patrão nem de chefe, nunca respeitei isso, entendeu, nem tenho a intenção de respeitar, 
nem me considero chefe de nada e nem quero que ninguém faça isso por mim. Então... as vezes, a nossa direção, não falando mal, entendeu, porque o erro é humano, aconteceu tantas divergências políticas, e... o nosso Movimento até... chamou até pra racha, isso foi um dos maiores erros que eles fizeram na época, entendeu, e que até hoje tem sequelas disso, é... então o que enfraqueceu um pouco a nossa relação com o nosso Movimento foi isso, entendeu, mas o nosso Movimento é muito bão, o que tá sendo assim... de forma estranha, o que agiu de forma estranha foi alguns dirigentes, mas a bandeira não tem nada a ver com esse... com essas pessoas, nós continuamos amando a nossa bandeira e... não importa a situação que está, que esteja, que...vivemos, a nossa bandeira é isso e nós não abandonamos, agora... diferenças políticas, divergências políticas, isso aí... espero que um dia a gente vai superar isso, entendeu, vamos dar a volta por cima e... continuar seguindo nosso objetivo." (Sr. Ivan, entrevista).

Se por um lado alguns assentados se sentem induzidos pela direção do MST para agir de certa forma, por outro, há resistências e enfrentamentos entre a liderança e a base. As resistências vão desde conversas paralelas, ausências nas reuniões e pequenos boicotes, até colocações explícitas de divergências em fóruns públicos, que são as reuniões de núcleo. Assim, em uma reunião no núcleo Paulo Freire, realizada para discutir algumas relações pessoais e relações entre liderança e base, Sr. Henrique, um assentado, pede a palavra e diz: 
- ‘Óia, pode ser que seja falta de compreensão política minha, a gente não sabe, mas se não tem compreensão política, isso é culpa da militância, de oceis passá pouco tempo aqui dentro, porque se oceis passasse mais tempo aqui dentro, viesse nas reuniões, explicasse as coisas pra nóis, nóis ia entedê melhor as coisas...' (Diário de Campo, p. 84; 11/01/2007).

Além disso, nem sempre a base se comporta de forma solidária com a liderança, apesar de verbalizar que se sente parte do MST, e de dizer que apóia a luta para que saiam mais assentamentos como o Sepé-Tiaraju. Exemplos da falta de apoio da base para o desenvolvimento da luta podem ser percebidos na motivação dada por alguns assentados para o acirramento das discussões entre base e liderança - a liberação dos recursos do fomento (R\$ 2.400,00), e a decisão de contribuir financeiramente ou não com o avanço da luta:

"Hoje está difícil o relacionamento entre assentados e MST. (...) 'Pra mim conquistar a fazenda, eu precisei da política do MST, agora eu já consegui, agora eu posso tocar', então eu acho que tem bastante pessoas que pensa dessa forma. Eu não penso assim, eu não tenho problemas com o MST não... Tem pessoas que se acham lesadas, mas aqui tá tipo dividido, eu vejo mais as pessoas que tiveram algum problema... pessoas que se capacitaram pelo Movimento, não vou citar nomes mas... então eu vejo eles assim, eles tem conhecimento de alguma coisa? Tipo, na própria associação tinha um acordo assim: ôh, vamos participar com 1\%, 3\%, assim, do crédito, na época acho que era o fomento, pra ajuda na luta, né, 
e a partir daí o pessoal começou a dizer que o Movimento tava querendo levar vantagem...” (Sra. Simone, entrevista)

Considerando que os militantes têm que despender uma quantidade bastante grande de seu tempo com a luta, a produção e a organização da casa inevitavelmente ficavam em segundo plano. Esse inclusive foi um dos fatores que acarretou um funcionamento deficiente do coletivo do Movimento, o Miraflores. A saída dos militantes para realizar trabalhos fora acabou por prejudicar a produção, e os assentados participantes da liderança ficaram “atrasados" em relação aos demais:

“Até as vezes você deixa a desejar na produção, mas... nem que você perde dias aí ocupando o INCRA, ou em outra luta, ajudando outros companheiros, então as vezes você fica um pouco atrás... Eu mesmo fiquei um ano e meio aqui, quase dois anos fora do meu lote, que eu tô correndo agora que é pra eu recuperar esse tempo, mas... Trabalhando de outra forma, né, as vezes não é bem reconhecido isso, porque as vezes, depois que você conquista uma terra, um monte de companheiro que sai ai na luta, quem fica as vezes não reconhece isso. Tem hora que tem que ir mesmo. As vezes você perde até um pouco de roça, tô sendo sincero pra você, tô sendo franco, isso acontece, nesse primeiro momento. Eu perdi uma roça, que era primeira roça aqui, porque a hora que você vai [pra luta], começa a chuva, e não dá pra você colher, e é resultado as vezes de você tá numa luta e não sobra tempo pra você colher ou plantar [...].”(Sr. Marco, entrevista) 
Além disso, há que se frisar que o trabalho do MST após o assentamento é muito importante, e realmente concorre para manter esse indivíduo assentado, e evitar um novo êxodo rural. Através do trabalho desses militantes que "saíam para fora", no período de assentamento, a atuação do MST junto aos assentados e ao governo federal foi essencial na conquista de várias políticas públicas e sociais que contribuem para a fixação do homem no campo, como os dois créditos "fomentos", no valor de R 2.400,00 cada, o recurso para a construção das casas de alvenaria dos assentados, a inclusão do assentamento no Programa de Aquisição de Alimentos da CONAB, entre outros.

O que se percebe, inicialmente, é que não houve suporte dos outros assentados a essa liderança que saía para fazer o trabalho. A opção por concentrar toda a liderança em um só núcleo também dificultou esse apoio, pois boa parte do núcleo estava fora do assentamento.

$\mathrm{Na}$ verdade, há uma dificuldade de compreensão de parte a parte. Segundo a liderança do MST, quando começou a haver questionamentos, esses se deveram à conversão de um assentado, que era da liderança do MST, a uma religião fanática, e que este e os que se converteram com ele não aceitavam mais o trabalho coletivo. A solução encontrada pelo Movimento foi chamar para um "racha", como uma das lideranças do MST nos contam:

[Com relação ao Sepé-Tiaraju] o problema principal colocado pela Lígia foi a conversão de um assentado, Sr. Arthur, a uma religião evangélica fanática. 'Quando nos demos conta, havia uma igreja construída no assentamento, e vários outros assentados se converteram'. Isso teria causado problemas e um racha, porque esse grupo não quer trabalhar 
coletivamente, quer acabar com a direção do assentamento que se dá de forma coletiva, e quer que seja só um líder para liderar o assentamento [...]. Esse grupo havia marcado uma reunião para o dia 07/09, para destituir a diretoria da Agro-Sepé, e o MST chamou uma assembléia antes, no dia 02/09. Nessa reunião, foi colocado sobre o racha, sobre quem quer ficar no MST ou sair, que eles têm que decidir, e 'quem quiser fazer a reunião de quinta-feira (07/09), que já funde outro movimento, porque não tem problema ter dois movimentos no mesmo assentamento, mas que já se decidam já.' $\mathrm{O}$ outro grupo disse que tinha que ter a possibilidade de mudar o MST desde as bases, porque 'o MST não somos nós, a base?', e que então eles tinham que mudar a partir e segundo as bases. Segundo a Lígia, uma senhora falou que o MST existe para defender os pobres, os Sem-terra, e que a bandeira do MST é só um pedaço de pano que significa (representa) isso, como quem diz: "pode mudar'.

Aí a Lígia falou: 'imagina, falar isso para alguém para quem o MST é a vida, é tudo', aí a Lígia falou para a senhora: 'olha, você fala que é só um pedaço de pano, eu que não acredito na Bíblia podia falar que é só um pedaço de papel, mas não vou falar isso porque eu respeito, assim vocês também têm que respeitar o Movimento' (...) Essa reunião terminou assim, 'quem quiser funde outro movimento dentro do assentamento'. (Diário de Campo, p. 19, 05/09/2006). 
Por outro lado, um dos assentados que acompanhou esse processo, que não é evangélico e nem participa do grupo "dissidente", significa o acontecido de forma completamente diferente da liderança, falando a esse respeito nos seguintes termos:

“[...] porque o povo se sente... por mais que seja um povo assim... um pouco leigo, mas não são burro, eles são inteligente, entendeu, o próprio Movimento insinaro isso pra nóis, entendeu, reivindicar... eles tem isso com eles, porque eles aprenderam a reivindicar, entendeu, então... quando o povo reivindica acha que o povo tá errado. Não é bem assim... então tem que... tem que parar pra ouvir, entendeu. [...] O povo tem seus direitos, entendeu, por mais que algumas pessoas se sente dona do povo, acho que tá... passou da hora de criar assim... sei lá, uma nova ética revolucionária, entendeu... acho que é isso que tá faltando, uma ética revolucionária. E o povo... nossos dirigentes acabô perdendo um pouco essa mística aí, porque... o melhor jeito de falar, que nem diz em Marx, é fazer. Não adianta pregar teorias ou filosofias pro nosso povo, quando que na prática nós não fazemos isso. Temos que passar novos caminhos para que um dia se chegue sim a esse caminho que nós tamos sonhando que é o caminho da revolução, tanto revolução na cidade, revolução nas escolas, e revolução do campo, entendeu? [...]

[Mas o que aconteceu de tão grave, Ivan?] Olha, só o motivo deles [a liderança regional do MST] chamar pra um racha, isso é um tapa na cara do povo. Isso é uma das grandes sequelas que... que ainda existe no rosto das pessoas, entendeu. As pessoas, por mais humildes que sejam, elas também são ser humano, elas guardam mágoas, entendeu. E o ser 
humano guarda mágoa, por mais que ele, que ele fale que tá tudo bem, mas ele tem por dentro... [...] Então isso acabou deixando nossa comunidade um pouco.. quer dizer, pra ser sincero, a maioria da comunidade perdeu a confiança. Essa é uma das realidades, entendeu. E quando se perde a confiança, pra conquistar ela de volta dá um pouco de trabalho, então é o que eu tô falando, eles teriam que ouvir a base, entendeu?" (Sr. Ivan, entrevista).

O que se pode perceber é que há uma falta de diálogo e uma incapacidade de compreensão de ambas as partes. Os assentados referem nunca ter tido a intenção de romper com o Movimento, ou mesmo serem contra o trabalho coletivo. Na verdade, esse grupo é um dos poucos que ainda defende a realização do trabalho coletivo no assentamento, tendo inclusive colocado, de forma voluntária, a maior parte dos recursos do PRONAF nesse tipo de trabalho (Diário de Campo, p. 114; 16/03/2007). Além disso, a compreensão de que eles são de uma religião fanática fica um pouco questionada pelo fato deles trabalharem de forma conjunta com o padre e com as freiras que moram no assentamento, e terem uma proximidade muito grande com estes, como vimos anteriormente.

Por outro lado, já não se pode perceber uma abertura, por parte dos assentados, para o diálogo com a liderança, pois já se parte do princípio de que esta é autoritária e que não ouve o povo. Como vimos acima, não há uma solidariedade dos assentados com liberar essa liderança para o trabalho extra-assentamento, o que também gera mágoas na liderança, agrava os desentendimentos e o afastamento da liderança para com a base. 
Esse mecanismo, que D’Incao e Roy (1995) chamaram de “mecanismo de invalidações circulares", com assentados e lideranças já partindo de uma desqualificação da pessoa do outro, a qual já impede, a priori, que uma parte do grupo possa ouvir e considerar o argumento dos demais, contribui para o aprofundamento do desentendimento. O outro já é previamente rotulado de amigo ou inimigo, mostrando mais uma vez a força da mentalidade do ticket presente no assentamento.

Há que se pontuar também um excesso de libidinização/catexização da instituição MST por parte da liderança, percebido, por exemplo, na fala anteriormente citada da Lígia, principal liderança regional do MST. Com o excesso de catexização, o meio vira fim em si mesmo, e o movimento social perde o movimento, não podendo ser modificado, estando no mesmo nível de algo sagrado e imutável, como a Bíblia. Para Adorno, "O que se apresenta ao sujeito como inalterável se fetichiza, se torna impenetrável e incompreendido" (ADORNO, 1996, p. 406).

Segundo Adorno, a fetichização da organização é muito facilitada pelo fato de que se lida diretamente com as massas fracamente coesas das cidades, que tornam necessário a existência de estrutura, disciplina e coerência, o que pode ter como decorrência uma valorização da organização em si, levando a um desvio da catexia libidinal da idéia que cumpre o papel de aglutinadora para a instituição em si, que acaba por ser superinvestida.

Cabe lembrar que o MST trabalha justamente com as massas desorganizadas das médias e grandes cidades. Assim, a própria característica de seu trabalho, e a massificação das lutas pretendidas pelo Movimento, leva a um risco de se usar mecanismos psicológicos de formação de massas semelhantes aos usados para formar grupos regredidos, como aqueles utilizados pelos agitadores fascistas, quais sejam: estereotipia, identificação projetiva, fetichismo da organização, personalização e autoritarismo. 
Assim, o desejo, a idealização e o excesso de libidinização levam a uma dificuldade da liderança em lidar com a fragmentação, muitas vezes negando-a ou colocando a sua culpa no indivíduo, em vez de olhar para o todo social e sua influência nos processos sociais. O fato de colocar a culpa nos indivíduos pelas dificuldades de relacionamento, seja esse indivíduo parte da liderança ou parte da base do MST, contribui para mascarar os verdadeiros determinantes desses desentendimentos, turvando a compreensão da realidade social como um todo, e dos mecanismos que estão por trás dessa realidade.

De certa forma, isso contribui para que os desentendimentos se propaguem de forma ampliada, e os futuros assentamentos já nasçam sob o fantasma de uma repetição desse processo. Considerando que as reais motivações para os desentendimentos não são percebidas e tendem a serem reproduzidas, elas tendem a continuar enquanto não são explicitadas - seja nesse assentamento, seja nos assentamentos futuros.

Conforme pontuamos no início deste trabalho, a liderança tem uma expectativa, com relação a cada novo assentamento, de que ele será diferente, ou seja, que nele conseguirão construir uma experiência sem conflitos e sem fragmentações posteriores. Acreditam que chegarão a isso através da realização de mais atividades simbólicas (místicas), ou mesmo mantendo um "controle" maior sobre os processos sociais dentro daquele assentamento Assim, já saem de início, não só negando a realidade, com uma esperança que desafia o racional e as experiências que eles mesmos vivenciaram, e que, portanto, vai ser frustrada, como também assumindo uma postura que ignora o motivo da fragmentação, e acaba por reforçá-la em vez de superá-la.

O que se pode perceber é que o excesso de libidinização do MST como instituição em si, também dificulta o diálogo e a criação de espaços de discussão política e reflexão efetivos, tendo-se em vista que toda crítica é sentida como uma perda narcisista, o que 
contribui para inviabilizar qualquer possibilidade de diálogo. Cabe pontuar que as críticas são sentidas como perda narcisista não só pela liderança regional do MST, mas também pelos assentados, tendo-se em vista que eles investiram afetivamente e libidinalmente o Movimento. Assim, a crítica dirigida aos assentados por parte da liderança, de que eles teriam menos consciência ou que já não fizessem parte do MST, também é sentida como uma perda narcisista por parte da base.

Além disso, se a experiência (Erfahrung) já tem um impacto bastante grande para os indivíduos que participam do Movimento, no caso daqueles que participam da liderança, a possibilidade de participar de um movimento social que multiplica isso, e o impacto de poder provocar essa mesma experiência em outras pessoas, pode contribuir com libidinização em excesso do Movimento, levando a uma idealização do mesmo, o que pode turvar a capacidade de crítica, bem como suscitar o desejo de prolongar isso pelo tempo do assentamento, inclusive de forma "forçada" e artificial.

É interessante notar que há uma gradação subjetiva entre a liderança, atribuída pelos assentados. Há aqueles que estão mais próximos a eles, e a quem eles confrontam abertamente, e há aqueles a quem eles ficam constrangidos até de dirigir a palavra:

Sr. Fabrício [assentado] falou sobre a importância e a necessidade da liderança construir o seu barraco no assentamento, porque vem visita, gente de fora, e os lotes são os primeiros do assentamento, e não tem nada em cima, só mato, sem barraco, e que isso pega mal. [...] O André [liderança do MST] pediu a palavra e falou que seu lote é um dos mais plantados ali, tá inteirinho plantado com mudas e feijão de porco. 
Sr. Fabrício disse que no caso dele, o que ele falou na última reunião é que a Lígia e o Lúcio [lideranças do MST] não podem sair do Centro de Formação, o Rodrigo [liderança do MST] tá no Rio estudando, mas o André, como era da Cultura, que não tem trabalho o tempo todo, poderia ficar mais no assentamento, morar lá, e o Sr. Marco [assentado/liderança do MST] tinha concordado (Diário de Campo, p. 84; 11/01/2007).

Dentro dessa gradação subjetiva feita pelos assentados, o posto de maior destaque e respeito é ocupado por uma das lideranças do MST regional, que é assentada no Sepé Tiaraju. É uma figura com um grande carisma, uma força de atração e aglutinação impressionante, o que acaba por contribuir para um certo centralismo no MST regional, não tanto por motivos políticos e ideológicos, mas por razões subjetivas, visto que as pessoas não se sentem seguras de tomar decisões sem tê-la consultado antes.

No dia da inauguração do assentamento, quando essa liderança chegou na festa, foi cercada por vários assentados, que queriam cumprimentá-la. A quantidade de assentados era tão grande, que dificultava até que ela caminhasse (Diário de Campo, p. 54, 12/12/06).

É curioso observar que a autorização para o início da presente pesquisa não se deu após uma discussão e aprovação em assembléia, pelo conjunto dos assentados, mas após a anuência dessa liderança específica. Todos aqueles com quem falamos, inclusive da liderança do MST, diziam que a autorização tinha que ser dada pela Lígia. Da mesma forma, uma das primeiras perguntas feitas tanto por assentados quanto pelos técnicos estatais que prestam assistência técnica no assentamento, foi se já havíamos conversado com a Lígia, no tom de "ela aprovou a pesquisa?": 
A Helena [técnica do INCRA] também me perguntou se eu tinha conversado com a Lígia, o mesmo me fizeram a Flora e a Dona Ana. Parecia meio uma senha de autorização para eles poderem falar, se sentirem seguros (Diário de Campo, p. 34: 20/10/2006).

Em uma sociedade emancipada, a constituição psíquica autônoma dos indivíduos possibilitaria uma eleição racional dos grupos, e o ideal de ego, bem integrado, não demandaria/induziria a uma colocação de um indivíduo (ou do todo social) no lugar dessa instância.

Não é o que acontece na presente sociedade. Os indivíduos tendem a uma identificação alienada com o líder, abrindo mão das características e qualidades de seu próprio ego, em favor daquelas possuídas pela idéia ou pessoa que ele coloca no lugar de seu ideal de ego.

Segundo Freud (1996), através de mecanismos que envolvem a idealização, o indivíduo identifica o líder do grupo com algum sucedâneo de ideal de ego não satisfeito, e coloca essa pessoa no lugar de seu ideal de ego, investindo-o narcisicamente com valores e qualidades superiores, tendendo assim a se comportar para com esse líder de maneira submissa e abrindo mão de sua capacidade crítica.

Aparentemente, esse fenômeno ocorre no caso dos assentados em sua relação com essa liderança específica. Cabe salientar que a externalização do superego, a substituição da consciência autônoma e independente pela autoridade coletiva, heterônoma, estranha ao pensamento do indivíduo, faz com que o líder ou idéia que ocupa esse lugar seja facilmente substituível por outro (a) que cumpra a mesma função subjetiva, o que pode explicar o afastamento de parte dos assentados da liderança do movimento social (ADORNO, 2006). 
De acordo com Adorno (2006), a identificação com a figura da liderança é regressiva, pois os indivíduos, através de uma falsa projeção, colocariam o líder no lugar de seu ideal de ego, identificando-se com os outros participantes de forma narcísica. Em função do desencontro entre a fase histórica do esclarecimento e a não satisfação dos desejos continuamente suscitados no indivíduo, este, no seu íntimo, percebe que a identificação com o líder é falsa. Assim, essa identificação tem um caráter de impostura, ela é mais encenada do que real, tendo-se em vista que os indivíduos precisam dela para se adaptar ao sistema como um todo.

Considerando que essa identificação ocorreria então próxima à superfície da consciência, ela se constitui quase em um ato de vontade do indivíduo, podendo assim ser criada, manipulada e transferida de um líder para outro, tão logo seja interessante para o indivíduo e sua adaptação ao mundo administrado.

Nesse sentido, a indústria cultural atua reforçando e suscitando esses mecanismos de personalização e falsa identificação, que cumprem o papel de absorver o indivíduo ao todo social de forma infantilizada, ambivalente e regressiva.

A mesma coisa se dá no assentamento: a indústria cultural atua no sentido de reforçar o personalismo vastamente presente no campo brasileiro, bem como na sociedade como um todo. A forma como estão organizados os argumentos dentro dos produtos culturais como novelas, Big Brother, programas de auditório do tipo "Márcia Goldsmith", que estão entre aqueles consumidos pelos assentados, reforçam a idéia de um herói ou de uma heroína que possuem qualidades intrínsecas, e suportam os sofrimentos da vida com grande "personalidade", ou atuam com força e determinação para conseguirem o que querem, merecendo por isso o prêmio que obtém, e devendo ser imitados e louvados por isso. 
Há assim, a presença de elementos regressivos na relação dos assentados com a liderança, elementos esses como personalização, autoritarismo e narcisismo na relação com o grupo - tanto de parte da liderança quanto da base, e ambivalência psicológica da base para com a liderança e para com os outros participantes do movimento social. Há que se ressaltar que esses elementos já estavam presentes tanto nos assentados quanto nas lideranças antes deles participarem do movimento social, de onde decorre a facilidade de seu retorno e a tendência a reproduzir esses mecanismos no seu funcionamento interno.

A ambivalência de sentimentos da base para com a liderança pode ser percebida pela fala de alguns assentados, trazida pela liderança, de que eles estariam "endemoniados". Essa fala demonstra uma incapacidade de colocar a causa do mal nas pessoas que estão na liderança, ou pelo menos em algumas delas, o que indica que, bem ou mau, elas estão afetivamente investidas. Assim, o único caminho para manter a personalização da culpa, é despersonalizá-la e desviá-la para um ente fantasístico (FREUD, 1996).

Se os indivíduos têm afinidade com grupos que funcionam dessa forma, por outro lado, esse grupo (a autoridade coletiva) é facilmente substituível, desde que a função que ele ocupa se mantenha intacta. Não há um compromisso com aquelas idéias ou com o conteúdo, mas com a manutenção de uma estrutura/ um líder que cumpre uma função dentro do funcionamento psicológico fragmentado e heterônomo do indivíduo (ADORNO, 2006).

Outrossim, os indivíduos tendem a delegar para os outros o poder de decisão, em virtude do funcionamento subjetivo induzido por essa sociedade. A identificação com a autoridade coletiva, que é heterônoma, opressiva e estranha ao pensamento dos indivíduos é o que estes buscam, em virtude do seu superego externalizado (ADORNO, 2006). 
Por fim, cabe frisar que a liderança do MST não é algo único, homogêneo, mas é um espaço em disputa também, seja disputa de objetivos, projetos ou metodologia de trabalho. Dessa forma, durante o desenvolvimento da pesquisa, foi possível perceber várias divergências dentro da própria liderança, bem como a existência de dissidências e rearranjos internos.

Assim, dentro da mesma liderança local do MST, temos o Sr. Marco brigando para ficar mais próximo da base, para sair menos para atividades externas, achando que o contato da liderança com os assentados estava pequeno, concordando assim com parte da crítica formulada pela base, e do outro lado, outras lideranças que não concordavam com a crítica, desqualificando-a e dizendo que os assentados não compreendiam a necessidade de sair para fazer o trabalho fora.

Há que se considerar que as disputas internas por modelos e a necessidade de "fazer dar certo", engessa, num certo sentido, o processo dialético. Não que as discussões e as divergências sejam negativas, mas a necessidade de mostrar que o seu projeto dá certo, em detrimentos dos outros projetos, pode levar à adoção de uma postura reificada e que desestimula o próprio pensamento e a crítica, além de impedir o exercício de um olhar isento e não viciado sobre o objeto de análise (o próprio projeto). A interação com o objeto já parte, de início, de uma relação coisificada e não-verdadeira, que não permite uma real transformação dos indivíduos e do próprio objeto, no sentido da emancipação.

Além disso, não é de menor importância o fato de o MST já ser uma organização, como dizem Stédile e Fernandes (1999), pois isto implica em uma certa estrutura, o que acarreta algum grau de rigidez, de divisão, especialização e fixação de papéis entre os participantes, sejam eles liderança ou base. Assim, dentro da própria liderança, há aqueles que se encarregam somente das questões burocráticas, aqueles que administram os recursos 
públicos, aqueles que têm se tornado especialistas em políticas públicas, e aqueles que se ocupam do trabalho de militância propriamente dito, e que incentivam os indivíduos da base a se organizarem e a terem seus momentos de experiência e reflexão.

Considerando que a existência massificada não é inevitável, o Movimento poderia trabalhar no sentido de explicitar os elementos que levam o indivíduo e, em última análise, a própria liderança do movimento social, a adaptar-se ao sistema com o qual inicialmente haviam rompido, contribuindo assim para que os indivíduos possam tomar consciência e opor uma resistência voluntária e esclarecida à sua propensão e disposição a ser seduzido, a submeter-se. Problematizar em vez de induzir a um coletivismo forçado e artificial, que de todas as maneiras é regredido, contribui para manter a capacidade de reflexão e de autocrítica aprendida dentro da luta pela terra, e manter viva a chama de uma outra possibilidade de sociedade.

\subsection{Assentados e coletivos}

Segundo Zimmerman (1994), no caso do pequeno produtor em regime de economia familiar, as formas de trabalho coletivas são reconhecidamente melhores do que as individuais, pois the dão maior retorno financeiro, mais condições de concorrência no mercado e fornecem uma proteção mais efetiva contra os mecanismos de exploração do produtor/trabalhador rural no sistema capitalista, além de propiciar uma forma de convivência alternativa; por outro lado, a constatação racional e a compreensão deste fato, por parte dos assentados, não garante o sucesso dessa forma de trabalho, ou melhor, não 
garante sequer a adesão à forma de trabalho coletiva, estando em jogo aspirações, desejos, medos e costumes das famílias assentadas (ZIMMERMAN, 1994, p. 221).

No caso do MST e de sua intervenção no assentamento, há uma tentativa de coerência na proposta de uma reforma agrária de esquerda, não capitalista, e por isso a importância do coletivismo. Nesse sentido, a forma de trabalho coletivo é essencial para que se caminhe no desenvolvimento da consciência e na direção de uma sociedade alternativa, ao possibilitar uma nova forma de trabalho e de experiência, diferente da capitalista (BALDUINO, 1999).

Cabe pontuar que o MST pretende desenvolver uma prática coletiva em uma sociedade que fomenta a alienação radical de um indivíduo em relação ao outro, como uma alternativa ao atual modelo, que os teóricos do Movimento vão identificar como individualista, concorrente e concentrador (BALDUINO, 1999). O objetivo do MST com essa prática do trabalho coletivo é contribuir com a formação do que eles chamam de "sujeito coletivo", o Sem-terra (CALDART, 2004, p. 12).

Da mesma forma como o próprio Movimento como um todo, em seus documentos teóricos sobre o assunto, a liderança Regional não é unívoca em seu entendimento e suas propostas de coletivização, demonstrando abertura para tentativas de formas variadas, que incluem desde coletivos exclusivos para a comercialização, passando por práticas que coletivizam parte do processo de produção, parte do lote ou parte da posse dos meios de produção, chegando a coletivos que contemplam a realização de atividades lúdicas e culturais.

Algumas lideranças manifestam uma preocupação em coletivizar, mas deixando um espaço para que a pessoa tenha "o sonho dele", ou seja, exerça a sua individualidade: 
“Às vezes a família quer trabalhar sozinha, e o INCRA quer que trabalha coletivo. Ou até mesmo nóis [do MST] qué qui seja coletivo, mas aí, o que que acontece, como a gente tem experiência de outros assentamentos, que o pessoal pegou recurso e não aplicou direito e tal... mas aí não tem como também você impedir que alguém aplique esse dinheiro errado. Por que? Porque se ocê for falá assim: 'não, todo mundo vai ter que fazer desse jeito', não funciona. Então o jeito é ser democrático, mesmo, não tem jeito: ó, o assentamento saiu, quem quer trabalhar no grupo, trabalha no grupo; quem quer trabalhar sozinho, trabalha sozinho, e capacitar as pessoas para elas podê trabalhar. Então aí dá certo. [...] É um sonho que ela tinha que ela não conseguiu realizá, agora ela tá tendo a oportunidade de realizá." (Sr. Geraldo, entrevista).

Algumas lideranças também falam em cooperar ou associar inicialmente para a comercialização, e ir se estendendo para outros aspectos da vida, como cultural, lazer, serviços, etc. Um exemplo dessa postura é a de uma liderança bastante importante na direção regional e no movimento estadual, que verbaliza o desejo de produzir parte no coletivo, mas também ter uma parte reservada para a sua família, tendo em vista que veio para o assentamento por ter o sonho de ter o seu lugarzinho com a família, pra "criá as cria dele" (Sr. Vitor, entrevista).

Desde sua origem, a questão das formas coletivas de trabalho e organização sempre esteve presente no Sepé Tiaraju, seja como forma de ação adotada, seja como ponto de discussão. Na época de acampamento, havia dois grandes coletivos: o Zumbi do Palmares, composto pelos homens, e o Dandara, composto pelas mulheres. Nesse período, os acampados produziram de forma coletiva mais de doze toneladas de alimento, que foram 
distribuídos em um evento do MST na cidade de Ribeirão Preto, servindo como forma de sensibilizar a sociedade em relação à causa da reforma agrária, bem como para mostrar que já na época de acampamento eles produziam bastante e cumpriam sua função social. Essa produção coletiva serviu também para mitigar o problema da fome, que, como vimos, era bastante grande no momento de acampamento:

\footnotetext{
"Nós chegamos a doar, doar alimento pra Ribeirão Preto, tipo assim, doze toneladas. Chegá no centro de Ribeirão Preto, que é a Califórnia Brasileira, capital do agronegócio, e doar doze toneladas de abóbora, mandioca, feijão, quiabo, jiló, do a-cam-pa-men-to [fala com ênfase] que tinha aqui, na praça Quinze, perto do negócio de chopp que tem lá, no Pinguim. Os burguês tava lá tomando chopp [ri], e nós tava lá doando os produtos para a população”. (Sr. Vitor, entrevista).
}

Essas ações também tinham como função estimular a reflexão nas pessoas que vivem na cidade, posto que se compreendia que elas viviam de forma bastante automática, "de casa para o trabalho, do trabalho para a casa" (Sr. Vitor, entrevista), reproduzindo mecanicamente as idéias veiculadas pelos detentores do poder e dos meios de comunicação, que em geral são contra a reforma agrária.

Posteriormente, com a homologação do assentamento e com a chegada de mais quase quarenta famílias para completar o número dos assentados, os dois núcleos existentes foram reorganizados, e deram origem a quatro núcleos, como vimos anteriormente, com vinte famílias cada. 
Além disso, na época do acampamento, havia os Coletivos de organização do acampamento, quais sejam, os Coletivos de Educação, de Saúde, de Produção, de Disciplina, entre outros. Desses, como vimos, hoje funcionam somente os dois primeiros (Educação e Saúde).

Hoje, existem em funcionamento no Sepé Tiaraju coletivos dos mais diversos tipos, sejam os de trabalho, como os mutirões que se formaram para a construção das casas, os de cultura, como o Coletivo de Educação ou de organização da festa junina, que é mais sazonal e temporário, ou alguns coletivos de produção, sendo que alguns desses trabalham em conjunto algum pedaço de terra, e outros dividem implementos e maquinário agrícola, como tratores e picadeiras.

Ainda com relação à produção, além dos 3,6 hectares reservados para o trabalho familiar individual, o planejamento da divisão do assentamento reservou áreas em dois locais distintos para que cada assentado participasse de pelo menos dois coletivos diferentes de produção: o coletivo de produção do grupo de vinte famílias de cada núcleo, e o coletivo de produção das oitenta famílias em conjunto, que se constitui na área de produção da Agro-Sepé.

A organização política do assentamento também está baseada em uma forma coletiva de trabalho: cada um dos quatro núcleos com a sua coordenação, e a Coordenação Geral do assentamento, exercida pela Agro-Sepé, composta da diretoria eleita mais os dois coordenadores de cada um dos núcleos. Essa direção acumula a representação política com a incumbência de organizar o trabalho coletivo. No caso da Agro-Sepé, as reuniões, que são abertas a todos os assentados que desejarem participar, são na realidade o fórum de discussão política e de organização de todos os assuntos que dizem respeito ao assentamento. 
Se há várias formas de trabalho coletivo que se mantêm, de um tempo para cá, por outro lado, os pequenos desentendimentos e as divergências se fazem presentes com alguma constância no assentamento, tanto entre a base e a liderança do MST, quanto entre assentados e as instâncias do Estado, entre liderança do MST e governo federal e entre os próprios assentados. As divergências têm acarretado mudanças na forma de trabalho e na organização política e social do assentamento, levando à fragmentação desses coletivos, além de ocasionar alterações nas relações pessoais entre os envolvidos.

Com a liberação do PRONAF-investimento, houve rearranjos e divisões nas áreas de produção coletivas, em muito permeadas pelas divergências. Houve a criação do que os assentados e os técnicos chamaram de "grupos de afinidade produtiva", subdivisões dos núcleos-base que ocorreram segundo os critérios pessoais de afinidade e de desejo de trabalharem juntos.

Com isso, nos quatro núcleos, a área destinada à produção coletiva foi dividida entre os grupos de afinidade que surgiram naquele núcleo. $\mathrm{O}$ mesmo aconteceu com a área coletiva de produção dos oitenta, que foi dividida em quatro partes "na corda", destinando uma parte a cada um dos núcleos, para que pudessem entrar na conta de divisão para os grupos de afinidade. Segundo Dona Ana, militante do MST,

a área coletiva dos vinte está agora sendo dividida em sub-grupos, conforme o tamanho dos grupos. [...] aí calcula quanto cada um tem direito na área dos vinte, se aquele grupo tem nove, é nove vezes x que o sub-grupo pode plantar na área do coletivo (Diário de Campo, p. 149; 08/06/2007). 
Como relatado acima, a Agro-Sepé está há quatro anos sem regulamentação legal, o que impede o acesso aos créditos para produção de forma coletiva. Nos dois anos de pesquisa, a área comum não foi plantada por falta de recursos, apesar do desejo dos assentados de plantá-la. Isso foi decisivo para que os assentados optassem por dividir a área "na corda", em quatro partes, uma para cada núcleo de vinte famílias, para que ela pudesse ser cultivada. Como já dito acima, essa área foi somada com a área coletiva já existente para as vinte famílias em cada um dos núcleos, e dividida de acordo com o número e o tamanho dos grupos de afinidade, não existindo hoje mais áreas destinadas ao trabalho coletivo das oitenta famílias ou mesmo de cada um dos núcleos integralmente, mas somente áreas de trabalho coletivo segundo a divisão em grupos de afinidade.

A subdivisão em grupos de afinidade teve significados diferentes para militantes e técnicos do INCRA, e para os assentados. Para os militantes, as instâncias coletivas (núcleos de base e coordenação geral) continuavam com suas funções políticas e funcionando normalmente. A mesma expectativa tinham os técnicos que prestam assistência aos assentados.

Já para parte dos assentados, não havia mais necessidade de participar dos núcleosbase ou da Coordenação Geral, visto que o coletivo onde ele ia trabalhar era o de afinidade. Havia a reclamação a respeito do excesso de reuniões, visto que os grupos de afinidade também faziam reuniões para planejar e executar os trabalhos, bem como havia discussões em função dos modelos de produção diferentes, influenciados pelas dificuldades de relacionamento pessoais, que agora passaram a vir à tona. Assim, em alguns núcleos, as reuniões se tornaram quinzenais, e mesmo assim passaram a ter uma participação esvaziada. Em uma reunião da coordenação geral, a técnica do INCRA, Helena, tentou explicitar a diferença entre reunião de núcleos e de grupo de trabalho: 
Começou a falar da importância da reunião, que os núcleos não tinham acabado com a criação dos grupos de afinidade, que os grupos de afinidade eram pra trabalhar juntos, que você não é obrigado a trabalhar com quem não confia, mas que os núcleos continuam, é ali onde se passam as informações, onde se decidem as coisas. [...] Falou que era impossível repetir lote por lote as informações que eram dadas ali, e que os coordenadores de núcleo também não poderiam repetir vinte vezes a mesma coisa, para isso é que tem reunião de núcleo (Diário de Campo, p. $163 ; 27 / 06 / 2007)$.

O fato de ter dividido em grupos de afinidade, no entanto, não garantiu o retorno a um trabalho coletivo e solidário, semelhante ao da época de acampamento, de que os assentados se ressentem. Na verdade, logo as divergências se fizeram presentes também nos grupos de afinidade, e muitos já se romperam. Segundo o Sr. Fabrício,

No núcleo Paulo Freire tinha dois grupos de afinidade, o Miraflores e outro grupo com quatorze famílias. Esse último grupo que estava tendo problema, que rachou em nove / cinco, e o grupo menor alegava que os nove não os estavam aceitando, que os estavam excluindo, e eles não sabiam porquê (Diário de Campo, p. 162; 27/06/2007).

Sr. Chico [assentado] pediu pra Helena [técnica do INCRA] marcar uma reunião com o grupinho de afinidade, porque estava uma 'brigaiada', por causa de uma picadeira, que ele a princípio não tinha querido participar, 
tinha dito besteira para o Celso [assentado], mas que ele tinha se arrependido e pedido desculpa, mas o Celso não teria desculpado, e teria dito que naquela picadeira ele não picaria nada (Diário de Campo, p. 168; 27/06/2007).

Segundo pesquisadores de diversas áreas, há uma tendência dos coletivos irem se fragmentando após o assentamento das famílias, e a união observada na época do acampamento se perde. Podemos observar que esse processo já dá claros sinais de estar acontecendo no Sepé Tiaraju. No que tange ao observado nos grupos de afinidade produtiva, nos quais os assentados se agruparam segundo laços de proximidade afetiva e de identificação, o que se pode perceber foi um desmonte rápido dos mesmos, devido a desentendimentos internos, com os consequentes rompimentos de relações pessoais. Nos documentos do MST estudados, há uma identificação da fragilidade desses grupos, que pode ser reportada à reificação a que também os grupos pequenos estão submetidos nessa sociedade. O retorno puro e simples aos grupos espontâneos ou grupos de afinidade, preconizado por alguns teóricos, não se constitui em uma panacéia para a falta de experiência, de solidariedade ou de coletivismo, posto que nessa sociedade, mesmo os grupos pequenos e próximos, nos quais os homens se identificariam, já não se prestam mais à identificação, estando também absorvidos e instrumentalizados pelo mundo administrado, contribuindo com a massificação e a heteronomia dos indivíduos (HORKHEIMER; ADORNO, 1973).

Em contraposição a isso, o MST sugeria um aprendizado em coletividade para os assentados, que não estariam acostumados a esse tipo de experiência. Propunha a coletivização de pequenas atividades ou tarefas e, conforme a aprendizagem dos indivíduos 
se desenvolvesse, ir coletivizando progressivamente outras atividades ou tarefas. No entanto, o que se pôde observar na prática, é que a liderança local do movimento social delegou aos técnicos a organização do trabalho coletivo dos assentados e, paralelo a isso, tentou organizar um coletivo de lideranças para servir de exemplo aos outros assentados. Como já pontuamos, essa opção levou a um afastamento entre liderança e base, agravado pela presença diminuída dessa liderança dentro do assentamento.

Há que se observar que nas reuniões de discussão do PRONAF, houve uma indução por parte de técnicos e do movimento social de usar o crédito de forma coletiva, o que foi acatado na prática, mas gerou muitas controvérsias e conversas paralelas. Os técnicos do governo federal, que, como já dissemos, em geral têm uma afinidade política com o discurso e com o ideário do MST, também reforçam e estimulam a organização do trabalho em forma coletiva:

Augusto [técnico do INCRA] pediu a palavra, e lembrou que os dois fomentos que tinham saído eles tinham colocado o dinheiro no lote individual, essa tinha sido a opção deles, e deixar para trabalhar na terra coletiva quando saísse o PRONAF. Lembrou que a terra individual era de mais ou menos três hectares, pequena, e que os recursos para pagar o PRONAF depois do período de carência sairiam mesmo da área comum. Falou sobre a importância da solidariedade, de trabalhar em conjunto, [...] que eles tinham que se unir pra dar certo (Diário de Campo, p. 114; 16/03/2007). 
Essa fala não encontrou muito eco junto a uma parte dos assentados, que reclamam de não haver solidariedade dentro do assentamento:

Um outro assentado pediu a palavra, e disse que isso de solidariedade era muito bonito, só que ele não tinha visto isso ali nunca. Que ele mesmo tinha ficado doente e ninguém foi ajudá-lo, e que o Sr. Emerson [assentado] tinha precisado bater o arroz correndo porque ia chover, e ninguém tinha ajudado (Diário de Campo, p. 115; 16/03/2007).

Há a emergência de desentendimentos, desconfianças, bem como o surgimento de problemas novos, como a entrada de "agregados" que não participaram luta, assentados que começam a tentar arrendar os lotes, ou assentados "andorinhas", que só moram no lote e trabalham na cidade; problemas com os quais aparentemente têm dificuldade de lidar tanto os assentados, quanto a liderança do MST e os técnicos do INCRA.

Para parte dos assentados, a solução é 'cada um cuidar da sua vida', numa alusão ao trabalho individual. Muitos demonstram uma preocupação com que o assentamento fique desfigurado, ou que os problemas gerem dificuldade de convivência entre eles, com o consequente afastamento um do outro.

Contaram que está havendo um desentendimento entre os assentados, pois alguns estão trazendo para morar no Sepé os “agregados", que são pessoas de fora, que nem são parentes, que são trazidos para os lotes porque têm dinheiro. Dona Simone brincou dizendo que ia trazer o 
Antonio Ermírio para ser seu agregado (Diário de Campo, p. 37; $10 / 11 / 2006)$.

Para outra parte dos assentados, a exclusão do que é divergente é o caminho citado como solução dos problemas, exclusão essa que surge na fala de um assentado ligado ao MST na metáfora do "paredão":

'- Você faz o assentamento, fala em formas coletivas de trabalho, e tem sempre aqueles que são do contra.' Então, na opinião dele, na época de acampamento, devia pegar todos os acampados, falar 'o projeto é assim, quem quer?' e colocar no 'paredão' quem não quiser. Perguntei se dava pra diferenciar, se não tinha aqueles que falavam que eram a favor, e depois que fossem assentados, se mostravam contra. Ele disse que não, disse que dava para distinguir um do outro no acampamento (Diário de Campo, p. 119; 05/04/2007).

Na fala dos militantes do MST, aparece com frequência a questão da falta de consciência dos demais assentados para se explicar a origem dos problemas ou desentendimentos, bem como a falta de união entre os assentados:

Rodrigo [liderança do MST] pediu a palavra e disse que o problema preocupava [...] porque talvez fosse um problema de compreensão política, de compreender que eles saíam 'para fora' para fazer um trabalho importante, que permitiu que saísse um assentamento como aquele (Sepé), [...] e eles estão trabalhando para ter mais. [...] 'A gente 
precisa ter entendimento político, união' (Diário de Campo, p. 83; 11/01/2007).

$\mathrm{Na}$ fala dos técnicos, aparece a questão do dinheiro como motivação para o surgimento das dificuldades.

\author{
Helena [técnica do INCRA] me perguntou o que fazer, disse que os \\ assentados não conseguem se organizar mais, que foi só sair o dinheiro \\ que começou a 'brigaiada', que compraram por conta própria, ao \\ contrário da recomendação técnica, tratores e implementos \\ desnecessários, que para o assentamento todo, um trator dava, e ainda ia \\ ficar sem uso em uns dois anos (Diário de Campo, p. 169; 27/06/2007).
}

Já os assentados se defendem da acusação de não terem consciência, e reportam a uma postura autoritária por parte do MST e da assistência técnica na relação com eles, tentando impor uma forma de trabalho ou de organização. Assim se coloca o Sr. Arthur, assentado, em uma reunião da Coordenação Geral: "temos que sair deles, é uma ditadura, nóis não vamo deixar pôr algema em nóis (...), primeiro é a coordenação (MST), agora é eles (INCRA) querendo mandar na gente" (Diário de Campo, 131; 09/05/2007).

Além disso, também aparece a questão do dinheiro no discurso dos assentados, seja corroborando a posição apresentada pelos técnicos do poder público, de que quando o dinheiro entra os assentados já não querem saber mais de mobilização, seja acusando a direção do MST de ter o mesmo comportamento, ou seja, de ter se afastado da base em 
função de estar tendo uma vida tranquila financeiramente. Sobre o comportamento da base a partir do momento que saíram os recursos, assim se manifesta um assentado:

"A partir do momento que entra dinheiro... o dinheiro muda a vida das pessoas, entendeu, querendo ou não, em toda sociedade, muda a vida das pessoas, então as pessoas começam a se sentir, sentir, como se diz, dona do nariz, entendeu, já não acha mais que... que aquela discussão coletiva, que aquela... aquela mística coletiva que tinha, entendeu, porque todas reunião tinha uma mística, então a coisa era mais movimentada pela mística da vida, entendeu, a partir do momento que pegaram recursos, fomento, PRONAF, a pessoa acabaram muitos pensando de forma diferente, aonde que eu digo que as coisas poderiam estar bem melhor [se tivessem continuado trabalhando de forma coletiva]." (Sr. Ivan, entrevista).

Já com relação à direção do MST, assim se posiciona outro assentado:

"É assim: quando eles andava descalço, eles era uma coisa. Eu não tô falando da luta, tô falando dos soldado. Quando eles andava descalço, era 'oi companheiro' daqui, 'oi companheiro' de lá. Hoje eles andam tudo calçado de pneu, cada um com o seu... entendeu, às veiz até dá as costa pra gente.” (Sr. Rogério, entrevista)

Cabe pontuar que os rompimentos e rearranjos ocorreram de forma mais significativa e mais intensa após a liberação do crédito PRONAF. 
Assim que é assentado, o trabalhador rural passa a se inserir na lógica do equivalente, na lógica de produção de mercadorias para poder sobreviver. Na época do acampamento, isto esteve um pouco suspenso, pois os assentados dependiam em muito da solidariedade das pessoas da cidade para sobreviver - isso aparece com muita força no discurso de assentados e de lideranças, de que têm que retribuir "o tanto que o povo da cidade e das universidades" os apoiou na época do acampamento, com comida, roupa, remédio, etc... Depois de assentados, todos esperam que eles se insiram na lógica do mercado, sejam os agentes estatais, seja o próprio movimento social, seja a sociedade como um todo, incluindo aí os meios acadêmicos, ao dizermos que o assentamento "tem que produzir para mostrar que a reforma agrária dá certo". Produzir implica em inserir-se no mercado para vender e comprar e, portanto, inserir-se na lógica capitalista.

Assim, entrar na lógica do equivalente e da mercadoria, que acontece após o assentamento, se torna um fator de desagregação na luta, pois o tempo dos assentados passa a ser medido e mediado pelo fator mercadoria.

Com isso, a adaptação termina por se efetivar: aquilo que era diferente, é registrado em sua diversidade e passa a ser absorvido pelo sistema capitalista. Como diria Adorno, o participante da reforma agrária volta a participar do capitalismo, que acaba por encontrar uma função útil para ele dentro do mundo administrado, que é a de produtor rural.

Com a inserção no mundo administrado, que implica uma submissão ao princípio do equivalente, a relação com o outro passa a ter significado e sentido para o indivíduo somente a partir do momento em que vai lhe trazer algum ganho, algum lucro. A participação no grupo passa a ser pesada segundo o princípio do equivalente: considerando que o coletivo é uma construção que implica em investimento de tempo, discussões, avanços e reveses conforme os indivíduos se apropriam daquela experiência, participar do 
coletivo pode significar, de forma imediata, dispêndio de tempo que se poderia utilizar para produzir e ganhar dinheiro, passando a ser entendido como "perda de tempo".

$\mathrm{Na}$ verdade, a relação com o outro, seja dentro ou fora dos coletivos, passa a ser medida pelo princípio do equivalente, mediada pela lógica da mercadoria. O pragmatismo e o utilitarismo passam a tomar conta das interações ente os indivíduos e estes são, então, coisificados, transformados em objetos que podem atuar contra ou a favor dos interesses do sujeito.

O indivíduo que mede o outro pelo princípio do equivalente, também mede a si mesmo segundo esse princípio, tornando-se mais vulnerável à pressão para adaptar-se ao padrão socialmente vigente.

Se o princípio do equivalente passa a operar no assentamento com a entrada de recursos e com a necessidade de se inserir como produtor e comerciante dentro do mercado, cabe lembrar o estado de miserabilidade em que se encontrava aquele indivíduo quando foi assentado. Assentados e lideranças do Movimento pontuam que após oito anos acampados “debaixo da lona”, mesmo o pouco que o indivíduo tinha quando era miserável na cidade, já se perdeu, já se quebrou. Assim, quando o acampado começa a se fixar na terra e formar seu lote, tem que construir tudo (sua casa, sua produção) a partir do zero absoluto. Na fala desses indivíduos, o estado de miserabilidade em que se encontravam quando foram assentados é praticamente ignorado pelo governo federal e pelo próprio movimento social:

“Por exemplo, eu pego R \$ 16.500,00. Nossa! É muito dinheiro! Não é nada, não é nada! Que projeto você faz com $\mathrm{R} \$ 16.500,00$, prum camarada que não tem nem uma panela pra cozinhar? Se ele pegar o dinheiro a primeira coisa que ele vai pensar é em ir comprar uma panela. 
E aí? O camarada tem o direito de comprar uma panela ou não tem?" (Sr.

Geraldo, entrevista).

"Porque quando a pessoa chega num nível de assentamento, a gente foi chegar no assentamento com oito anos de luta, então não tem mais nada, até o fogão véio que já trouxe da cidade, aquilo já se destruiu. Então ele tá cozinhando na 'trempe', né, feito na lenha. Então, essa é uma dificuldade muito grande.” (Sr. Angelo, entrevista).

Assim, as condições objetivas em que se encontram os indivíduos quando são assentados, contribuem para uma busca ativa desses assentados pelo mercado, por bens e produtos necessários e mínimos para a sua sobrevivência, como uma panela. Essa necessidade legítima é significada muitas vezes como individualismo, tanto na fala de alguns técnicos, quanto por alguns líderes, quanto pelos próprios assentados. A desconsideração dessas necessidades deixa o assentado à sua própria sorte, e tão logo ele consegue algum recurso, é natural que invista nesses pontos, como ter um cômodo no qual se abrigar, uma panela para cozinhar, uma cama para dormir. A desconsideração dessas necessidades e a condenação velada ou explícita do uso que se fez dos primeiros recursos a que tiveram acesso (crédito "fomento", no valor de R \$2.400,00 cada) também contribuem para a construção de uma falsa idéia do que vem a ser a participação em um coletivo no assentamento, pois reforça a idéia de que toda e qualquer necessidade individual deve ser sacrificada em função do coletivo: 
Augusto [técnico do INCRA] pediu a palavra, e lembrou que os dois fomentos que tinham saído eles tinham colocado o dinheiro no lote individual, que essa tinha sido a opção deles. [...] Falou sobre a importância da solidariedade, de trabalhar em conjunto, falou sobre 'o mundo inteiro estar de olho neles', que eles tinham que ser exemplo [...]. (Diário de Campo, p. 114, 16/03/2007).

Nesse sentido, o próprio INCRA contribui para a fragmentação dos coletivos: por um lado, não fornece as condições mínimas necessárias para que as propostas de coletivo possam funcionar, condições essas que seriam de sua responsabilidade, como, por exemplo, a água, por outro, pressiona no sentido de que os assentados trabalhem de forma coletiva, reforçando a posição do Movimento. Com relação às condições mínimas para o desenvolvimento do trabalho, a água é somente o mais gritante elemento de responsabilidade do Estado cuja falta prejudica o trabalho, mas há uma ausência generalizada de equipamentos sociais ou de uma estrutura que favorecesse tanto a produção quanto o desenvolvimento social dentro do assentamento, seja de forma individual ou coletiva.

Outro exemplo dessa intervenção do INCRA que desestimula o andamento do trabalho coletivo é a questão da Associação dos oitenta assentados, a Agro-Sepé. Por um lado, o poder público exige uma associação para que o assentamento no modelo PDS possa existir, por outro, o Sepé Tiaraju existe há quatro anos sem a associação estar legalmente regulamentada, o que é muito negativo no entendimento dos assentados, pois somente com a regulamentação e a oficialização da Agro-Sepé, eles poderiam ter acesso de forma coletiva (como associação) aos créditos de produção. Assim, conforme já relatamos, nesses 
dois anos que acompanhamos o assentamento, a área coletiva não foi plantada por falta de recursos, apesar do desejo dos assentados de cultivá-la. No final desse período de acompanhamento, após terem esperado quatro anos pela ação do INCRA, os próprios assentados decidiram, em reunião dos núcleos e da coordenação do assentamento, dividir a área "na corda", para que ela pudesse ser plantada.

Como já pontuamos acima, a falta de infraestrutura comprometeu as possibilidades de se desenvolver atividades coletivas, bem como leva a desentendimentos e fragmentações, reforça a visão do assentamento como lugar somente de produção, ao não proporcionar condições objetivas para o desenvolvimento de atividades sociais, lúdicas ou de lazer.

O próprio MST contribui, num certo sentido, com a dificuldade em se implementar formas alternativas e cooperativas de trabalho e convivência, bem como com a fragmentação das poucas experiências coletivas existentes, pois como vimos no tópico anterior, ao sancionar uma forma determinada e única de intervenção, acaba por solapar formas espontâneas de organização coletiva. Se as formas "espontâneas" efetivamente são mais frágeis que as formas organizadas de coletivos, elas podem servir de instrumento de aprendizagem e de base para o surgimento de formas mais "avançadas" que, segundo o Movimento, seriam as cooperativas de produção.

Outrossim, o Movimento também não foi efetivo em contribuir com o surgimento de formas mais avançadas, como a associação, em virtude do não apoio jurídico efetivo ao registro da Agro-Sepé. A posição assumida pela direção regional e pelo advogado do MST, ainda que correta em termos de conteúdo, sujeitou-se a uma racionalidade instrumental, pois desconsiderou o resultado de sua intervenção, bem como as decorrências de sua própria análise - a de que nessa sociedade uma associação de trabalhadores rurais encontra 
mais resistência em ser aceita, em comparação com as associações de grandes latifundiários. Se a análise da direção regional e do advogado do MST está correta, a ação de não fazer nada para adequar o estatuto da associação às determinações jurídicas, por se tratar de uma questão de enfrentamento político, teve consequências desastrosas: inviabilizou qualquer iniciativa de produção coletiva no assentamento, sendo que as áreas separadas para esse fim ficaram sem uso por três anos seguidos, o que acarretou na divisão da área para ser plantada de maneira individual.

Quanto à proposta de trabalho, de organização e de divisão dos lotes, segundo a liderança do MST, esta se deu com ampla discussão em todos os núcleos do acampamento, “com a participação ativa da Direção Regional e de parceiros da sociedade que poderiam contribuir com as propostas para o novo jeito de fazer assentamentos, de acordo com os debates já acumulados” (CONCRAB, 2004, p. 30).

É perceptível uma preocupação da liderança em incentivar a discussão, o diálogo, e a livre criação dos indivíduos. Assim, quando foram discutir com os assentados como eles queriam o assentamento, a direção regional arrancou as últimas folhas da cartilha enviada pelas instâncias nacionais, posto que ali havia modelos já prontos, e eles queriam que a organização final fosse produto dos assentados. Assim nos conta Margô, técnica contratada pela CCA/MST:

O Sepé está organizado segundo os princípios do 'raio de sol'. Quando nós fomos discutir com a comunidade, arrancamos os mapas do final da cartilha, para que o pessoal não olhasse e dissesse: 'tem que ser assim, só pode ser igual a esse', mas para que eles discutissem o modelo e 
chegassem na organização que eles desejassem (Diário de Campo, p. 9; 18/08/2006).

No entanto, o que se vê na fala dos assentados, inclusive daqueles que são militantes do MST, é a sensação de que algo não foi suficientemente conversado ou lhes foi imposto, seja com relação ao tamanho do lote, seja com relação à produção agroecológica. Segundo Sr. Flávio, assentado que tem uma proximidade muito grande com o MST,

\footnotetext{
'- Acho que se fosse assentado no 'Carlos Lamarca' era melhor. Lá o lote é maior, é tudo individual. Aqui, no começo, o combinado não era pra ser parte individual e parte coletivo, era pra ser tudo individual. Se eu soubesse que ia ser assim, não tinha vindo, não ia sair do acampamento que a gente tava.' (Diário de Campo, p. 67; 11/01/2007).
}

Já segundo a sra. Simone, assentada, eles

\begin{abstract}
Tinham sido obrigados a assinar um documento em que diziam que iam produzir sem usar agrotóxico, e que se não cumprissem, são expulsos do assentamento [...]. Perguntei se era obrigado a assinar, e ela disse que achava que não, mas que o povo fazia pressão, a militância fazia pressão (Diário de Campo, p. 147; 08/06/2007).
\end{abstract}

Conforme pontuamos anteriormente, a atuação do movimento social, ao tentar manter-se no assentamento, acaba por tolher a liberdade do processo argumentativo, e a contribuir com um reforço da minoridade do indivíduo. No mundo administrado, o que é 
divergente não é tolerado, tudo deve ser homogêneo e consensual, nem que para isso o indivíduo tenha que abrir mão de seu pensamento e da integração do seu ego.

Assim, manter um espaço para a divergência e para a discordância, para a ocorrência efetiva de um processo de discussão não tutelado e livre é mais importante do que chegar a um resultado final pré-estabelecido, pois o participar do processo e estimular o desenvolvimento da reflexão e do pensamento não pré-moldado, é o que leva a um rompimento com a mentalidade do ticket.

Se muitas vezes, com sua atuação no assentamento, o MST acaba por assumir uma postura autoritária e não emancipadora, há que se lembrar que a capacidade de perceber e criticar isso, por parte do assentado, foi desenvolvida através de sua participação no Movimento.

Além disso, cabe pontuar que a reificação e as relações alienadas, típicas do sistema capitalista, estão internalizadas e se fazem presentes no assentamento, sob as mais diversas formas. Nesse sentido, a mesma ponderação que o assentado faz em relação ao MST não é aplicada, com a frequência necessária, às outras relações sociais autoritárias a que está submetido, as quais tende a reproduzir.

Na verdade, a simples presença do MST no assentamento estimula uma crítica ao capitalismo, trazendo à tona a importância da reforma agrária, da necessidade de manter-se mobilizado, apoiando o surgimento de novos acampamentos e assentamentos, e de continuar a luta, a fim de poder manter-se assentado.

Ao fomentar a discussão como importante em si, como forma de estimular a construção da autonomia, da consciência e da capacidade crítica, o Movimento pode contribuir com uma real possibilidade de crescimento da consciência e de contraposição crítica ao estado de coisas dado como natural por essa sociedade capitalista. 
Por outro lado, ao induzir os indivíduos a aceitar formas pré-estabelecidas de organização e de trabalho, ainda que sejam formas organizativas consideradas "progressistas", o Movimento contribui para a coisificação dos indivíduos, com a transformação desses objetos, submetendo-os à racionalidade instrumental e ao mundo administrado.

Adorno, falando da liberdade de espírito nos países socialistas que estudou, considerando que a existência de indivíduos não tutelados é pré-condição para a emancipação e autonomia do homem, vai pontuar que a condição subjetiva para que o indivíduo possa realmente se colocar é a liberdade de juízo, com o não enquadramento deste em normas. Segundo Adorno, (1992, p. 182), “o juízo não enquadrado em normas está em extinção, enquanto seus trejeitos continuam a ser efetuados com um ritual de grupo. Basta Stalin pigarrear, e eles atiram Kafka e Van Gogh na lata do lixo”.

Além disso, como discutimos no tópico anterior, assumindo essa postura, de certa maneira, o Movimento contribuiu para uma minoridade do indivíduo que inviabiliza a existência de fóruns de discussão onde a palavra de todos os participantes tenha o mesmo peso, o que é necessário para a existência de qualquer trabalho coletivo que tenha a intenção de contribuir com o desenvolvimento do indivíduo e a autonomia desse assentado.

Cabe retomar a análise adorniana acerca da participação em coletivos: a participação em um coletivo pode ser emancipadora ou totalitária (ADORNO, 2006). A participação emancipadora em um coletivo tem como características a adesão voluntária e racionalmente escolhida, a identificação positiva entre os participantes, a escolha autônoma dos objetivos a serem seguidos e a possibilidade de realização da verdadeira igualdade, que é aquela que deixa espaço para a individualidade. 
Para que a participação em um grupo fortaleça o indivíduo e sua subjetividade e, como consequência, fortaleça a própria coletividade, ela não pode acontecer como decorrência de coação; o indivíduo deve se reconhecer como parte daquele grupo, sentir-se ouvido, considerado, respeitado. Retomando Rouanet (1985), o indivíduo tem que ter liberdade de propor, argumentar e contestar normas, para que ele possa ter uma participação política efetiva, que contribua com o desenvolvimento de uma verdadeira consciência, não deformada pelos mecanismos de defesa, os quais visam uma adaptação ao que é heterônomo e, por vezes, violento. Somente uma participação plena e verdadeira em um grupo é que pode propiciar um encontro entre os homens, e o surgimento da verdadeira solidariedade.

Além da questão de como se desenvolve o processo de discussão, a própria prática do coletivo não é, em si, a panacéia para todos os males. Realizar uma atividade coletiva pode não significar um rompimento com a lógica capitalista, como pretende o Movimento, mas justamente em função de como as coisas são colocadas e do como se estabelecem as relações entre aqueles que estão conduzindo o processo e aqueles que compõem a base do Movimento, a participação no coletivo pode significar um recrudescimento da alienação.

Lembrando Adorno, esta não é uma sociedade individualista, mas é uma sociedade coletivista, que induz ao coletivismo e despreza o que é realmente individual. Partidos e grupos de esquerda muitas vezes reproduzem um coletivismo alienante, ao impor formas de trabalho cooperado, que não consideram a individualidade e o espaço de desenvolvimento da auto-determinação dos indivíduos, que deve acontecer de forma concomitante ao desenvolvimento da identidade coletiva.

Schereiner (2002) vai relatar experiências de trabalho coletivo em alguns assentamentos estudados por ele, nos quais até a visita de parentes (como filhos, por 
exemplo) à casa do cooperado tinha que ser autorizado pela direção da cooperativa. $\mathrm{O}$ coletivismo exacerbado, que abafa toda autonomia do indivíduo, não passa de uma resposta reificada à reificação do todo social (VAZ, 2004).

Esse não é o caso do Sepé Tiaraju, mesmo porque, como vimos, as possibilidades de trabalho coletivo previamente planejado efetivamente não se concretizaram. Por outro lado, nem por isso, a pressão para que ele se realizasse segundo um modelo previamente estabelecido foi menor, tanto por parte do movimento social, quanto por parte dos agentes estatais.

Um outro ponto a ser considerado, é que quando saiu o assentamento, cerca de metade das famílias que hoje estão assentadas no Sepé teve que ser transferidas de outros acampamentos, para se completar o número de oitenta famílias. De acordo com a liderança do MST, isso dificultou a posterior configuração do assentamento, tendo em vista que aproximadamente $50 \%$ das famílias não participou do processo de discussão da organização do Sepé Tiaraju. De fato, parte dos assentados pontua que houve várias discussões, e que o INCRA trazia mapas de organização do assentamento para eles discutirem, já outros assentados demonstram não terem participado do processo, desconhecendo-o completamente.

A chegada de quase metade das famílias, vindas de fora, também gerou desentendimentos e conversas paralelas, tendo em vista que os que ficaram oito anos no acampamento Sepé Tiaraju falavam que as famílias de outros acampamentos que foram selecionadas para vir completar o número de famílias necessárias eram próximas à direção do MST.

Nesse sentido, a opção por deixar a formação para o período de acampamento cria certos impasses e desentendimentos no assentamento, tendo em vista que devido à 
dinâmica da luta, as pessoas têm um histórico de formação diferenciado, em função de terem tempos de discussão no acampamento diferentes. Alguns dos assentados no Sepé Tiaraju estiveram acampados por somente seis meses, alguns nem chegaram a estar acampados, sendo que esses casos ocorrem especialmente entre as mulheres.

Com relação à postura dos assentados frente às propostas de trabalho coletivo, o que se pode perceber é que não há, a princípio, uma posição contrária da maior parte dos assentados de tentar alternativas coletivas de trabalho, mas as condições objetivas a que estão submetidos, a falta de estrutura e de condições de trabalho, e uma lógica racionalizante e burocrática que eles não compreendem, acabam por solapar as tentativas coletivas de acontecerem.

$\mathrm{Na}$ verdade, os assentados manifestam uma recusa às falsas experiências de cooperação com as quais eles tiveram algum contato no passado, como as "coopergatos", onde há efetivamente um dono, que usa a fachada de cooperativa para contratar os indivíduos sem pagar os direitos trabalhistas, capitalizando-se com isso, enquanto os outros são superexplorados. Na fala de alguns militantes, os assentados remetiam a este tipo de cooperativa, quando se começou a falar do trabalho coletivo:

"Eu acredito ainda que, a hora que bem ou mal se vai produzindo, que a gente vai adquirindo essa forma de se organizar, de organizar a produção. Que a cooperativa, ela esteja funcionando, organizada também, que nós temos [tenhamos] uma tecnologia mais prática, que tenha um computador trabalhando... Porque, nesse primeiro momento se você... você procura uma transparência, porque até o nome de cooperativa, de trabalho coletivo, muitos que vêm da cidade falam daquela antiga cooperativa que 
era um ou outro pra levar vantagem mesmo, então não tá bem assimilado isso." (Sr. Marco, entrevista).

Nesse sentido, os assentados são muito mais receptivos à sugestão de "associação", porque remete a um trabalho conjunto que eles aceitam, e se mostram desconfiados quando ouvem falar de cooperação, porque associam à idéia de cooperativa de fachada, onde um é patrão e manda nos outros, reproduzindo uma forma de trabalho alienada, a qual eles muitas vezes foram submetidos. Assim, quando falam em cooperativas, a questão de ter saído da cidade para não ter mais patrão aparece na fala dos assentados como motivação para não querer trabalhar no coletivo, avaliando que se eles trabalharem "cooperados", a liderança vai assumir o lugar de autoridade ou de patrão.

No discurso dos assentados, é perceptível que eles também tinham esperança de manter a mesma relação de solidariedade e de trabalho coletivo que tinham na época do acampamento, e que as fragmentações e desentendimentos os pegam despreparados, e sem elementos para compreender o fato, o que, de certa forma, contribui para aumentar as tensões e os desentendimentos: se eu tenho certeza de minhas boas intenções e de que quero me manter no coletivo e não consigo, a culpa certamente deve ser do outro que não deve ter consciência ou deve estar boicotando essa forma de trabalho. A ausência de uma visão realista, associada à idealização que se faz do assentamento como uma nova sociedade, agrava a questão da individualização da culpa pela fragmentação, feita tanto por lideranças, quanto por assentados, quanto por agentes estatais.

Observando-se a disposição de boa parte dos assentados em participar dos coletivos, bem como essa esperança que eles nutriam de que fossem conseguir manter a mesma união 
que tinham na época do acampamento, podemos concluir que efetivamente há a formação de uma identidade coletiva de "Sem-terra", conforme pontua Caldart (2004).

Como pontuamos anteriormente, a participação no MST proporcionou a esses indivíduos, que hoje são assentados, uma verdadeira experiência, que se caracteriza pela criação de uma identidade coletiva, ao mesmo tempo em que se fortalece a identidade individual, proporcionando ao mesmo tempo autonomia e uma história ancorada no desenvolvimento do coletivo.

É interessante notar que essa identidade coletiva criada não se desfaz com os desentendimentos e rupturas que ocorrem no assentamento, posto que os assentados continuam se sentindo "coletivos", chamando a si próprios de "militantes" ou de "Semterra" mesmo após romperem com a liderança regional do MST.

Cabe pontuar que a própria identidade do indivíduo se modifica consideravelmente após o assentamento. O acampamento constitui um tipo de coletividade diferente do assentamento. Esse entendimento é partilhado inclusive por alguns membros da liderança, que conseguem fazer uma autocrítica e pontuar que o acampamento "não cabe dentro do assentamento" (Sr. Geraldo, entrevista). O assentamento enseja um tipo diferente de coletividade, em relação ao tempo de luta, e "pelo simples fato de que são coletividades diferentes" (ROS, p. 132), a identidade de assentado é diferente da identidade do acampado.

Assim, com o assentamento, há uma mudança de identidade, uma necessidade de construir uma nova identidade, que não exclui a identidade de "Sem-terra lutador do povo", mas que agrega uma série de novos elementos, como a de produtor rural inserido no mercado, e a de cidadão que não está mais à margem da sociedade, mas tem um lugar valorizado e inserido politicamente na comunidade local. 
Não é questão de dizer que agora ele é "com-terra", com o fim de desmobilizar a luta, como muitas vezes intentam o governo e as elites, mas trata-se de reconhecer as especificidades e diferenças desse tipo de lutador em relação a um acampado. Reconhecer essas especificidades é essencial para poder continuar realizando um trabalho de mobilização adequado junto a esta população.

Cabe lembrar o que é pontuado por Caldart (2004, p. 136), de que a partir do momento em que é assentado, o indivíduo passa a se organizar segundo a lógica de uma pequena "empresa social". Dentro da concepção do Movimento, a produção é a base da nova vida que se pretende construir no assentamento, e esta é organizada segundo a lógica do sistema capitalista onde está inserida. De acordo com Caldart (2004, p. 137),

[...] os sem-terra que cortam cercas [...] são também aqueles que se tornam dirigentes de empresas, que negociam em Bancos, que fazem parcerias, que contratam técnicos e discutem as diretrizes de sua assessoria, que organizam sua produção em agroindústrias e que chegam até a regular mercados regionais através da produção agrícola que comandam. (itálicos no original).

O fato de a tônica ser a produção, com os indivíduos sendo inseridos na lógica do mercado e tendo que se comportar como "dirigentes de empresas", não passa sem deixar seu impacto no Sepé Tiaraju: a lógica do sistema capitalista passa a influir dentro do assentamento, não só na produção, mas se refletindo também nas próprias relações que se estabelecem entre os indivíduos e entre esses e o movimento social. 
Ademais, o movimento social precisa explicitar o fato de que está inevitavelmente trabalhando com mesma lógica capitalista, ao intervir no assentamento, visto que seu objetivo é impedir que esse assentado seja expulso da terra, e que ele consiga manter-se através da capitalização e da inserção no mercado. Ocultar essa contradição, (mecanismo da negação somado à fantasia de que o assentamento é uma 'terra liberta') sabota o processo de conscientização e leva não somente os assentados, mas o próprio movimento social, à sucumbir a ideologia. Segundo a Teoria Crítica, "os que sucumbem (à ideologia) são exatamente os que ocultam a contradição, em vez de acolhê-la na consciência de sua própria produção" (ADORNO; HORKHEIMER, 1985, p.147).

Além disso, a dificuldade de o Movimento e os assentados conseguirem colocar em prática uma alternativa efetiva de trabalho coletivo também contribuiu, com o tempo, com a volta das formas familiares de cooperação, que são aquelas conhecidas de longa data pelos assentados, e cujo modelo de organização e trabalho lhes serve de referência. As próprias lideranças do MST voltaram-se para uma estratégia familiar de sobrevivência, e como exemplo podemos citar o Sr. Gustavo, assentado pertencente à militância do MST que construiu sua casa de adobe com o trabalho e o apoio de toda a família, após esperar o mutirão composto por lideranças do MST, e que não ocorreu. Outro exemplo é o do Sr. Dimas, um senhor bem idoso, também construiu a casa em sistema de mutirão com a ajuda da família, que vive na cidade e não no assentamento, bem como com a ajuda de outras famílias assentadas, que não eram do grupo de mutirão a que ele pertencia.

Outro ponto que se pode observar é que essas famílias que se organizaram dessa forma tradicional, ou seja, com o apoio da família consangüínea, de parentesco simbólico ou agregados, estavam em uma melhor situação de desenvolvimento e qualidade de vida do 
que as que optaram por aguardar a realização de um trabalho coletivo, que até o presente momento, na maioria dos casos, não se efetivou.

O próprio MST se aproximou de uma estratégia familiar, seja como Movimento, seja na postura de suas lideranças. Como Movimento, há estratégias familiares em todo o processo de ocupação e acampamento que são legitimadas pelo MST, como a presença de mulheres e crianças (famílias completas) já desde o período de acampamento, para que todos possam se envolver na luta e avançar na consciência; preferir manter as famílias que têm alguma afinidade ou identificação juntas, etc...

Além disso, a proposta da liderança regional quanto ao Sepé Tiaraju era a de constituição de grupos de afinidade, no qual as pessoas não precisariam trabalhar juntas com outras com as quais não possuam vínculo afetivo ou não se identificam. Nesse sentido, a concepção apresentada pela liderança regional é até mais respeitadora das características do camponês do que a proposta nos documentos do MST. Assim, se nos documentos oficiais há uma visão negativista do camponês, a prática da presente liderança não manifesta esse tipo de visão negativa, pelo contrário, inclusive vários líderes optaram por uma estratégia semelhante (familiar).

Ainda que os próprios assentados digam o contrário, o que se pode observar nas interações entre assentados é a presença constante da ajuda mútua, principalmente entre as famílias mais próximas. A ajuda, a troca e o apoio recíproco eram observados nas mais diversas formas de interação, com os mais diversos objetivos e abrangendo as várias facetas da vida em um assentamento, desde o trabalho, passando por questões sociais, de educação, de saúde, de lazer, de comercialização, etc.

$\mathrm{Na}$ verdade, a estratégia de organização social adotada no assentamento é muito semelhante à descrita por Moura (1991), que se constitui como uma estratégia 
eminentemente familiar, na qual durante os períodos tranquilos, cada família subsiste de forma mais ou menos independente, e nos momentos de crise, as famílias se agrupam e se ajudam mutuamente.

Entre as interações de trabalho ou comercialização onde presenciamos ajuda entre os assentados, podemos citar o caso de assentado levando produto de outro para vender na cidade, empréstimo de ferramentas e máquinas de trabalho, cessão, troca ou doação de combustível, de plantas e de animais, "troca de dia", repassar comprador para o outro, aconselhar quanto à plantação (época e planta ideal), cuidado com os animais, dicas de agronomia (inseticidas orgânicos, controle de formiga, caju em terra arenosa, etc.).

Nesse meio tempo, chegou o Fred, veio pedir emprestado o trator da Dona Ana, porque tinha acabado o combustível dele (Diário de Campo, p. $184 ; 06 / 10 / 2007)$.

Dona Sulamita estava com um senhor de camionete pequena, que estava comprando milho. Ela chamou o seu Fernando para vender. A caçamba estava cheinha, e tinha também abóbora, mandioca, e banana para fritar (Diário de Campo, p. 94; 30/01/2007).

Entre as interações sociais nas quais observamos ajuda mútua entre os assentados, citamos a cessão ou doação de alimentos e roupas, entre outros; o apoio, acompanhamento ou aconselhamento em casos de saúde, o cuidar de crianças, almoços, mutirões dos mais diversos, em especial em situações onde era necessária força braçal: 
Na chegada ao assentamento, passei pela casa de Fabrício e Dona Luana. Vários vizinhos estavam ajudando a levantar um cômodo de uma casa, junto com alguns parentes. Perguntei se já era a casa feita com os recursos do INCRA/Caixa, e Dona Luana me falou que não, que era um cômodo que o Sr. Fabrício estava levantando para ela, porque ela ia ganhar neném na segunda. [...] Sr. Fabrício estava matando um leitão, e me falou pra passar lá depois para comer com todo mundo (Diário de Campo, p. 65; 11/01/2007).

De qualquer forma, pode-se perceber a presença bastante grande de laços familiares, e de laços sociais entre famílias muito próximas, que já se consideram como aparentadas. Efetivamente, boa parte das estratégias de trabalho e de sobrevivência está ancorada nesses laços familiares e de "compadrio". É bem comum o trabalho feito através de associações entre parentes, que acabam formando uma rede tanto dentro do assentamento quanto com outros assentamentos.

Da mesma forma que a subjetividade, quando não é nomeada, a estratégia familiar também está lá, mesmo quando é negada, posto que essa é uma estrutura de referência para o trabalhador pobre do campo ou da cidade, ainda que essa forma de organização tenha decaído ou diminuído com o avanço do capitalismo.

Também está presente a questão da solidariedade para com os de fora, tanto os que a liderança do MST e os assentados chamam de "amigos", que estiveram com eles durante os momentos de luta e por quem eles nutrem uma certa gratidão, quanto para com os moradores da cidade em geral. Nesse sentido, quando fala sobre comercialização e obtenção de bons preços no mercado, Sr. Flávio se posiciona da seguinte forma: 
'- A gente não pensa muito nisso não, de querer vender mais caro, porque a gente acha que tem que dar um retorno para a sociedade... se não o que adianta? A sociedade apóia a gente, se você ver o tanto de gente que teve aqui, na ocupação, no acampamento, a polícia vinha tirar a gente e eles tavam aqui, saiam junto, voltava a ocupar e eles ocupavam junto, era o pessoal da universidade, da igreja, da cidade... então a gente tem que pensar em vender alimento mais barato para a cidade, e não ganhar dinheiro em cima deles.' (Diário de Campo, p. 68; 11/01/2007).

Há um saudosismo do tempo do coletivo, bem como um desejo de voltar à união que eles tinham nesse tempo, ainda que hoje eles continuem se enxergando como coletivo.

\footnotetext{
"Naquela época [acampamento], era um precisando do outro, entendeu. Hoje não tem mais aquela coisa. [...] Não tem... ainda tem nossos grupos coletivos, entendeu, essa mística... um pouco essa mística ainda existe, mas essa não é igual ao que era antes, entendeu?" (Sr. Ivan, entrevista).
}

De uma forma geral, os assentados estão bastante satisfeitos com sua vida no assentamento. Todos, sem exceção, se referem ao assentamento como aquilo pelo que eles lutaram e conquistaram, como algo muito desejado, como vitória, como algo que finalmente pode lhes trazer sossego. A fala sobre a importância de apoiar outras lutas como a que eles tiveram também é presença recorrente no discurso dos assentados. 
Há vários planos de futuro no discurso dos assentados, e o clima geral, apesar das dificuldades pontuadas, é de que "tudo aqui está bom, e ainda vai melhorar mais ainda" (Dona Luana, Diário de Campo, p. 106; 15/03/2007). Ter a terra efetivamente é visto como liberdade e libertação, como possibilidade de viver com dignidade e como ser humano pleno:

"Mudou bastante, a minha vida mudou bastante, ainda não tá do jeito que a gente qué, mas pelo menos hoje eu... não tenho aquele compromisso de acordar as quatro horas da manhã, ou as vezes as três horas da manhã pra tá pegando a condução pra ir trabalhar, pra alimentar meus filhos. Hoje, mesmo sabendo que ainda tem um longo tempo ainda, que todos começo é difícil, e a gente tá começando agora, mais pelo menos, se um dia eu tá muito cansado, eu posso levantar um pouco mais tarde, eu não tenho ninguém me esperando pra eu picar cartão, ou eu chegar na chapeira e o cartão as veiz já tá recolhido, pra veiz eu precisa até ir no escritório, arriscado até perder o emprego, e pensá que minha família vai tê que passa fome. Então isso foi uma grande mudança pra mim. Hoje a gente faz o possível pra produzir, pra que os filhos comem a vontade, e não igual era no passado, as vezes comprava o leite e só tratava do mais novo, os mais velho tinha as mesmas vontade de tomá o leite, e a gente tinha que tá conversando: óia, ceis tem que dexá pro mais pequeno, que o dinheiro não dá pra comprar pra tudo vocêis. As veiz até uma banana que comprava, tinha que tá dividindo de um em um, porque não dava pra deixá eles comê a vontade. E nisso hoje, já é completamente diferente. Tem produção, eles comem. Se sobra, dá pro porco, não tem problema, o 
porco mesmo depois a gente vai comê a carne, comê a banha, então isso foi uma grande mudança pra mim.” (Sr. Ângelo, entrevista)

Segundo Schereiner (2002), ter a terra e trabalhar com a família representa uma possibilidade de autonomia, dentro da lógica do assentado. Esse raciocínio remete ao ideário camponês mais tradicional, onde estava presente a possibilidade de ir à cidade só para comprar o sal e o querosene (CÂNDIDO, 1987), que é referida e desejada com saudosismo e nostalgia por esses novos agricultores, que não tiveram essa experiência, mas cresceram ouvindo-a dos mais velhos (MARTINS, 1997).

Não que esses assentados queiram realmente isso. Como já pontuamos, as necessidades de consumo, individuais e coletivas, são altamente influenciadas pela indústria cultural. Assim, os assentados querem também ter uma motocicleta, uma televisão, uma máquina digital, o computador, além de tratores e implementos agrícolas de última geração.

Além disso, é bastante claro que nessa sociedade cada vez mais engolida pela lógica do capital, essa autonomia decorrente da produção familiar em sua própria terra é somente uma ilusão. Não é desnecessário lembrar que a família é uma formação socialmente constituída e, portanto, determinada em grande parte pelo funcionamento da sociedade em que está inserida.

Há que se pontuar que a tão sonhada posse privada de um lote individual, que como pontuamos anteriormente, é desejado por vários assentados e significada como uma possibilidade de realização de um espaço de autonomia e independência para a família, também é ambígua e, por vezes, ilusória: a posse da terra representa também o acúmulo de um bem material mensurável, que na prática pode ser vendido como qualquer mercadoria. 
Por outro lado, a lógica da organização familiar pode ser uma possibilidade de contraposição à lógica do capitalismo. Segundo Adorno, o camponês resiste mais fortemente à expropriação produzida pelo sistema capitalista, em virtude de seu vínculo com a terra, à qual estão vinculadas idéias de auto-suficiência e independência (HORKHEIMER; ADORNO, 1973). Não se trata de querer a volta de uma forma de organização tradicional, tampouco de ignorar as críticas que são feitas a esse modo de organização, mas recuperar aquilo que apresenta enquanto negatividade frente à totalidade reinante (ADORNO, 1996).

Segundo alguns autores, a forma de inserção do camponês no capitalismo brasileiro aponta para a existência de aspectos de sua vida que não se submetem completamente à lógica da mercadoria:

Da mesma forma que o uso comum da terra, o mundo da mercadoria repudia o uso do trabalho comum - a menos que o trabalho se transforme numa mercadoria e sirva para produzir a mais valia. Ora, ao contrário do colono descendente de europeus, o caboclo não existia socialmente como produtor de mercadorias, suas relações sociais com os outros homens não passavam fundamentalmente pela necessidade de vender e comprar. (Abramavoy, 1981, p. 30, apud Schreiner, 2002, p. 324).

Não que consideremos a lógica familiar camponesa como revolucionária, ela é em determinados aspectos e em certos momentos bastante conservadora, barbarizada até, como pontua Adorno, sendo reprodutora de desigualdades e de opressão. Retomando Moura (1991), o camponês não tem, como uma segunda natureza, uma constituição em si 
conservadora ou revolucionária. Não há que se romantizar a cultura e os costumes camponeses, nem condená-la. Por outro lado, diante da proposta alternativa, que na prática não se efetivou ou não foi realmente alternativa, a organização familiar tem um quê de utópica e de resistência, no que ela nega da sociedade dada, de relações não-coisificadas e não submetidas à lógica da mercadoria, e do que ela contrapõe como promessa de solidariedade e de uma igualdade irrealizada, da "vontade de uma outra sociedade" (ADORNO, 1992, p. 17) em um sistema que já acabou com a própria solidariedade familiar, submetendo até mesmo essa à lógica do equivalente.

Cabe sublinhar que o retorno puro e simples aos grupos "espontâneos" e ao trabalho familiar ou por afinidade não é a panacéia para todos os males, posto que nesta sociedade, mesmo os grupos pequenos e próximos ao indivíduo também estão alienados e induzem á heteronomia (HORKHEIMER; ADORNO, 1973).

Isso pode ser percebido no assentamento estudado, nos microgrupos de afinidade que se formaram, e que posteriormente se fragmentaram por discussões econômicas e por desentendimentos pessoais e na forma de trabalho coletivo. Cabe frisar que dentro do sistema capitalista, há uma tendência a que os grupos espontâneos e que contribuem com o fortalecimento do indivíduo, de sua identidade e de sua subjetividade se rompam e se fragmentem, sendo substituídos por grupos artificiais que cumprem a função de reforçar a alienação do indivíduo e de promover sua adaptação ao todo social administrado.

Mas o papel do Movimento não é o de "obrigar" os assentados a aprender isso, ao inseri-los em experiências pré-definidas de trabalho coletivo, mas problematizar a vivência dos indivíduos nos grupos dos quais eles participam, contribuindo para a reflexão e o desenvolvimento da consciência autônoma e crítica. A adesão coagida a um grupo, 
qualquer que seja ele, acaba por contribuir mais com a adaptação ao sistema alienado que se quer combater, do que com seu questionamento.

Mais do que respeitar o ritmo dos assentados, como o MST coloca em seus documentos sobre organização dos assentamentos, uma postura que fomenta a autonomia deve respeitar realmente o desejo dos assentados quanto a organização da sua forma de trabalho e de sua vida, não partir já do pressuposto de que aqueles indivíduos têm que trabalhar segundo uma forma coletiva pré-estabelecida, desprezando-se as formas coletivas mais simples conhecidas pelos assentados (MARTINS, 1997). O "respeitar o ritmo" traz em si a idéia de que o lugar onde o assentado tem que chegar já está dado, resta somente motivar e aguardar que ele caminhe em seu ritmo até chegar àquele lugar.

No caso do assentamento, a indução para se assumir formas coletivas de trabalho somente contribuiu para criar mais resistência nos assentados a essa forma de trabalho, e confirmar as suspeitas obtidas na vivência de cooperativas de fachada, de que o trabalho coletivo não dá certo, ao já se iniciarem com condições objetivas que levariam inevitavelmente ao seu fracasso, associado à sensação de imposição da proposta.

\subsection{O assentamento e o MST: algumas considerações}

Os grupos podem se estruturar e atuar de formas diversas, mediando a relação entre indivíduo e sociedade. No caso do grupo do MST ora pesquisado, ele deixa entrever - nos documentos estudados e em sua prática - que se organizou como um coletivo que possui 
um espírito de grupo, baseado em objetivos racionalmente determinados, quais sejam, o de lutar por reforma agrária e contribuir com a construção de uma nova sociedade, atuando no sentido de buscar a organização e o apoio das massas. Além das considerações racionais que servem à sua finalidade, pode-se dizer que o MST deixa entrever a existência de um espírito de corpo, de caráter ético, baseado em sua história e nas idéias construídas em comum sobre o grupo.

As formações grupais são inerentes à existência em sociedade, e seu funcionamento é determinado pela formação histórica específica na qual está inserido. No caso do MST, seus teóricos têm identificado um período de refluxo das lutas populares (CONCRAB, 2004).

É nesse período de refluxo das lutas, em função de uma hegemonia do capital, que surge o assentamento Sepé Tiaraju, dentro de uma região tipicamente dominada pelo agronegógico e sofrendo todo tipo de pressão para ser rapidamente absorvido pelo sistema capitalista.

Cabe lembrar que a sociedade em que vivemos hoje está inteiramente organizada, e pretende estender seu modo de organização a todas as formas de expressão, sancionando apenas comportamentos e pensamentos pré-figurados, a irracionalidade do sistema se manifestando em cada um dos indivíduos e em cada uma das organizações existentes dentro desse sistema. O que é dissonante não é tolerado, e tende a ser absorvido e apropriado pelo próprio sistema, em um totalitarismo homogeneizante. De acordo com a lógica do mundo administrado, essa absorção preferencialmente deveria se dar descaracterizando o próprio assentamento, solapando com isso sua possibilidade de contestação do modelo agrário vigente na região. 
Em função de sua existência, o Sepé Tiaraju anuncia a possibilidade de uma outra sociedade, sem patrão e sem exploração, onde os indivíduos podem viver com dignidade e independência de espírito. $\mathrm{O}$ assentamento representa uma contraposição viva ao modelo vigente, que é naturalizado e anunciado como a única forma possível de se viver, se você for um trabalhador rural pobre.

Como os assentados, mesmo aqueles que se dizem afastados da liderança regional do MST, não cedem às investidas diretas dos usineiros, que prometem várias vantagens àqueles que plantarem cana, o mundo administrado tem que se inserir no assentamento por vias menos explícitas, a fim de adaptar aquele indivíduo novamente ao sistema capitalista.

No caso do Sepé Tiaraju, como vimos, o princípio do equivalente entra no assentamento de forma direta, pela necessidade do assentado de comercializar sua produção, bem como através da atuação da indústria cultural. Além disso, a lógica do mundo administrado se insere no assentamento através da atuação do poder público, do movimento social e dos próprios assentados, que têm internalizado um padrão de comportamento e de sucesso ditado pelo todo social.

Com a entrada da lógica da mercadoria no assentamento, há uma desmobilização dos assentados, bem como um esmorecimento em sua contraposição esclarecida ao sistema capitalista. Esse fato, aliado à postura do MST e do Estado, contribui para que comecem a surgir os desentendimentos entre assentados, entre esses e a liderança, e dentro da própria liderança.

No caso do assentamento estudado, como vimos, a fragmentação é escamoteada e entendida como algo negativo, tanto para assentados, quanto para o movimento social e para os agentes estatais que atuam nesse espaço. 
Há que se frisar que a idealização do assentamento não contribui para o avanço da luta, mas somente para mascarar a realidade e induzir a uma falsa compreensão dos processos sociais e individuais que ocorrem na fase pós-assentamento, o que somente acentua a cisão e os desentendimentos, dificultando qualquer possibilidade de construção de um trabalho conjunto, que possa efetivamente contribuir com a emancipação dos indivíduos.

Não se pode fazer uma romantização do assentamento, que também é reforçada/tentada pelos próprios assentados e pela liderança do movimento social. Da mesma forma, não é possível romantizar o movimento social, apresentando-o como algo isento de contradições. Ambos (assentamento e movimento social) são espaços em disputa e, como todo espaço social, sujeito a contradições.

Romantizar o assentamento e mascarar as contradições que são inevitáveis, ou mesmo reportar essas contradições aos indivíduos (sejam eles os assentados ou a liderança), somente contribui para que essa relação com o todo social, da qual ainda não se pode escapar, seja velada e mistificada, contribuindo com a reificação e alienação do indivíduo, e com a dissolução da força contestadora do movimento social. Essa postura também engessa o movimento dialético, porque nega a contradição, contribuindo para que essa não possa ser superada, bem como veicula a idéia de que a síntese esperada para o futuro já aconteceu.

É interessante notar que tanto a liderança quanto os assentados personalizam a culpa, colocando no indivíduo a razão pela fragmentação no assentamento, não reconhecendo os determinantes sociais que impelem a experiência à fragmentação e os indivíduos à adaptação. A liderança personaliza dizendo que a culpa dos desentendimentos entre liderança e base é desta última, que é formada por individualistas ou oportunistas, ou que tiveram um recuo na consciência. 
Já no caso do assentado, cuja miséria socialmente engendrada foi o que o precipitou sua participação no MST, este aos poucos deixa de reportar à sociedade capitalista a causa de sua alienação ou de sua exclusão, e passa a culpar a liderança do movimento social por situações que estes muitas vezes apenas reproduzem. Assim, os assentados colocam a culpa nas pessoas que compõem a liderança regional, reportando a eles um comportamento autoritário, que por si só não explica a desconstrução de uma identidade coletiva, que na verdade se deve a fatores maiores e externos.

Além disso, tanto a liderança quanto os assentados personalizam a culpa no caso do INCRA, colocando-a nos técnicos, que então passam a sofrer pressão.

Da atuação do movimento social no assentamento, se pode depreender que há uma preocupação do MST em manter os assentados mobilizados e participando da luta, bem como impedir que haja um novo êxodo rural, com a consequente expulsão daqueles indivíduos novamente para a cidade. O trabalho do MST, além de possibilitar ao indivíduo o desenvolvimento de sua consciência, permitiu que várias políticas públicas chegassem ao assentamento, como os créditos de produção e os recursos para a construção das casas.

Por outro lado, com a presença do governo federal no assentamento, através do INCRA, que passa a ditar as normas de permanência ou exclusão dos assentados, o Movimento perde muito do seu poder de influência dentro do Sepé Tiaraju. Com isso, ao tentar manter-se, acaba por repetir o que condena: a posição do Movimento é apresentada aos participantes como a única possível, bem como é induzida sua assunção em bloco.

A organização em si é enfatizada, e o MST passa a ser fetichizado, ou seja, a instituição é absolutizada, superinvestida afetivamente, e toda crítica é sentida como traição em virtude da perda narcisista. O fato de sancionar o pensamento em bloco, bem como sentir a crítica como uma perda narcisista, leva à assunção de uma postura autoritária, que 
induz a uma atrofia da capacidade de pensamento e de reflexão que os indivíduos começaram a desenvolver com a própria participação no Movimento.

Assim, a necessidade do MST de manter sua influência, associado aos riscos reais à sua reprodução que tem ocorrido em sua atuação no assentamento, pode ter como consequência uma tendência a recusar posições ou idéias que suas lideranças sintam como ameaçadoras ou divergentes. Um risco muito grande para a liderança do MST é o de assumir uma postura onde não haja liberdade para discordar, onde o que o indivíduo pode pensar, o que é considerado como o pensamento de alguém que tem "consciência", é determinado e dado de antemão. Esse tipo de postura poderia ser caracterizado como uma "mentalidade de ticket", o pensamento em bloco. Ainda que, como disseram Adorno e Horkheimer (1985), o ticket progressista é mais humano que o conservador, o fato de induzir todos a pensar em bloco atenta contra a verdadeira liberdade, consciência e autonomia, contribuindo para a heteronomia e reificação do homem, enfim, buscando administrar seu pensamento e sua vida, e trabalhando contra a emancipação. Adorno (2006) também nos chama a atenção para o fato de que mesmo o movimento político mais progressista corre o risco de se deteriorar e chegar a esse ponto, se abrir mão de seu conteúdo racional em função da manutenção de seu poder.

O MST organiza pessoas que estavam excluídas, não tinham clareza de sua situação de exploração, muitas vezes vivendo na marginalidade, sem possibilidade objetiva de se organizarem por si só. A essa massa desorganizada, o MST transformou em um grupo coeso. A necessidade de organização e coerência, exigida ao se trabalhar com a base, corre o risco de transformar-se em um fim em si mesmo, tendo como consequência um fetiche da organização enquanto tal, com esta se transformando em um fim ao invés de um meio (ADORNO, 2006). 
Lembramos a posição de Adorno, para quem a capacidade de romper com a lógica do mundo administrado e com a barbárie que ela engendra depende da "autonomia, se é que eu posso utilizar a expressão de Kant, a força para a reflexão, para a autodeterminação, para a não participação" (ADORNO, 1986, p. 37).

Nesse sentido, a liderança assume uma posição de tutela dos assentados, que remete a uma crença em sua minoridade. Essa postura acaba por reforçar uma atitude de conformismo e submissão nos indivíduos, pondo a perder a capacidade crítica e de contraposição que eles aprenderam na luta. Nesse sentido, o movimento social acaba por reforçar o funcionamento heterônomo e alienado, típico da sociedade capitalista, contribuindo assim para que o mundo administrado se faça presente no assentamento.

Um outro ponto a ser observado é a presença, dentro do movimento social, de duas lógicas contraditórias que subsistem de forma perene e estrutural: a lógica do acampamento, que é a lógica da reflexão, do questionamento, da luta; e a lógica do assentamento, que inevitavelmente envolve as questões da produção, reprodução e de sobrevivência dentro da sociedade capitalista, com uma inserção inevitável dentro desta.

Nos anos oitenta, o MST fez a discussão quanto a continuar o trabalho de mobilização dos assentados em suas lutas específicas, em vez de criar um movimento social com esse intuito (o movimento "Pé no Chão"). Ora, as questões específicas dos assentados dizem respeito a como manter-se assentado dentro de um sistema que tende a expulsá-lo novamente para a cidade, e envolve questões como obtenção de crédito, facilitar a comercialização, evitar a pauperização, permitir a capitalização dos indivíduos, entre outros.

Caldart (2004, p. 137) vai inclusive nomear os assentados de "dirigentes de empresa", que atuariam segundo uma lógica da pequena "empresa social". Na verdade, 
coexistiriam, de forma tensa e dialética, dentro do próprio MST, as duas lógicas: a lógica do "rolo" (ou "do movimento") e a da "empresa social" (“da organização, do planejamento"), lógicas essas que, segundo a autora, foram decisivas para constituir a atual formação da estrutura do próprio Movimento, que por vezes atua com "uma pitada" da lógica da empresa social.

Essa lógica, encampada pelo Movimento, acaba por submeter o indivíduo e seu funcionamento subjetivo ao princípio do equivalente. A primazia dos aspectos econômicos e produtivos leva o Movimento a se deparar com questões "éticas" típicas do sistema capitalista, como: produzir para todos ou dirigir-se a nichos de mercado, que pagam melhor, mas atingem somente a elite; como se relacionar com outros pequenos produtores rurais não assentados, em especial quanto à questão do lucro, tendo-se em vista que muitas vezes se negocia com esses produtores; como comprar ou vender a indivíduos ou empresas que muitas vezes se colocam de forma contrária à reforma agrária, mas cujo relacionamento comercial permitirá capitalizar grandemente aquele assentamento ou aquela cooperativa (CALDART, 2004).

De certa forma, e sem perceber, o Movimento também fica submetido à lógica do equivalente, e acaba por reproduzi-la em sua relação com os assentados. Assim, o MST comporta dentro de si duas lógicas inversas e conflitivas, a lógica de um novo mundo que se pretende construir, e a lógica do sistema capitalista, que acaba por reproduzir, de forma involuntária.

Outro ponto negativo, e que concorre para o surgimento de discussões e divergências, é que a direção regional do MST tem recebido recursos do governo federal, bem como empregado técnicos para realizar trabalhos que antes eram considerados de responsabilidade estatal, utilizando-se de recursos públicos para isso. Há uma proximidade 
com o poder político instituído na esfera federal, que nesta pesquisa pode ser percebido pela atuação, em alguns momentos, dos técnicos estatais reforçando o posicionamento do Movimento, bem como pelo repasse de recursos para a contratação de técnicos pelo MST, para prestarem assistência técnica no assentamento.

A proximidade com o governo federal, que a princípio parece trazer ganhos ao movimento social, no sentido de reforçar seus modelos de ação dentro do assentamento, acaba por ser prejudicial ao Movimento, pois contribui para que este assuma uma racionalidade instrumental. Com isso, ambos (governo e movimento social) acabam por ser portas de entrada da racionalidade instrumental no assentamento, contribuindo assim com a adaptação dos assentados ao mundo administrado.

Pode-se depreender que a proposta do Movimento é o de assumir o trabalho do poder público, e fazê-lo de forma alternativa. Só que ele não consegue fazer isso, e passa a fazer o trabalho que tradicionalmente era de responsabilidade dos entes públicos, repetindo a mesma lógica da racionalidade instrumental. Há vários aspectos que acarretam essa reprodução do que se quer superar:

- primeiro, isso se deve em parte ao fato de que o Movimento, dentro de sua concepção teórica como organização, acaba por fazer eco a essa racionalidade instrumental e produtivista, que como vimos, acaba por reproduzir a lógica do mundo administrado;

- segundo, a necessidade de preparar os assentados para inseri-los na lógica de mercado leva necessariamente a uma reprodução dessa mesma lógica dentro do movimento social, com os assentados sendo compreendidos como uma pequena "empresa social";

- terceiro, a necessidade de se manter faz com que a reprodução do MST, de meio para se chegar a uma nova sociedade, passe a ser encarado como um fim em si mesmo, e o Movimento passa a se esforçar para reproduzir-se no assentamento, assumindo algumas 
vezes, por isso, uma postura autoritária, bem como contribuindo para a reprodução da mentalidade do ticket - a adesão em bloco e sem reflexão a posições políticas - dentro do assentamento.

O que podemos perceber comparando o que é enunciado pelo MST em seus documentos de orientação quanto à organização de um assentamento e o que foi visto na prática no Sepé Tiaraju, é que no geral há uma coerência entre o que é preconizado nos documentos e o que a liderança do MST tenta implementar no assentamento estudado. Assim, várias das posturas apresentadas pela liderança regional do MST, no caso do assentamento estudado, que reforçam o mundo administrado e contribuem com a inserção da racionalidade instrumental e da lógica da mercadoria dentro do assentamento, decorrem de diretrizes gerais colocadas pelas instâncias superiores do Movimento, e acabam por ser reproduzidas em outros assentamentos e acampamentos do país.

Por outro lado, a liderança local do MST, apesar das dificuldades apresentadas, é uma liderança altamente qualificada, preocupada com a qualidade e o tipo de intervenção realizada no assentamento. Pode-se perceber na atuação do MST regional um envolvimento com a transformação social, com a construção de uma nova sociedade, com o Sepé Tiaraju ser um diferencial e um exemplo para as cidades e populações do entorno, com a solidariedade para com os da cidade, com o trabalho coletivo, entre outros. A liderança busca fazer arranjos em sua atuação, mudando de postura ao longo do desenvolvimento da pesquisa, como passando a residir no assentamento, sendo que antes não moravam lá de fato. Também faziam discussões semelhantes à supervisão, com momentos de reflexão teórica e da prática realizada no assentamento, com assessoria de professores universitários envolvidos com o Movimento, incluindo aí professores da área de psicologia social. Segundo alguns membros da liderança, eles também modificam sua atuação em função dos 
resultados de pesquisas acadêmicas realizadas nos assentamentos onde têm intervenção, tendo-se em vista que estas os ajudam a perceber o que estão fazendo de errado e a ajustarem sua atuação (Diário de Campo, p. 17).

A colocação em segundo plano das questões subjetivas, patente nos documentos de circulação nacional do Movimento, não ocorre na prática, no assentamento. A direção regional está muito mais atenta às questões subjetivas, tendo inclusive organizado um curso de psicologia social para a liderança e para os militantes com algum trabalho no MST, visando sensibilizar e preparar esses militantes para lidar com a subjetividade e com a individualidade.

Nesse sentido, a atual liderança regional é inclusive menos autoritária e menos indutora de um ordenamento da vida do assentamento do que eventualmente podem ser outras lideranças que sigam a risca o que está preconizado nos documentos oficiais do Movimento, tendo-se em vista que esses apresentam uma posição de minoridade do indivíduo, bem como uma postura idealizada dos assentamentos.

Além disso, não se pode diminuir o potencial emancipador presente no MST. Se como pontua Sigaud (2005), ao entrar no movimento social, o indivíduo não está pensando em modificar a sociedade, mas optando por uma estratégia de sobrevivência entre as possíveis para ele (subemprego na cidade, trabalho volante nas fazendas, bolsa-família), cabe pontuar que o indivíduo que emerge após a participação no Movimento é diferente do que emerge do recebimento de benefícios sociais ou do trabalho alienado. No caso da participação no MST, os indivíduos se identificavam uns com os outros, tinham um contato real com o outro, ao mesmo tempo em que reorganizavam sua subjetividade em função da experiência que pôde ter ao participar do movimento social. Com seu pertencimento ao Movimento, o indivíduo experimentou a emergência de uma consciência autônoma, ao 
mesmo tempo em que construiu uma história coletiva, cujo conteúdo e significação eram partilhados pelos outros participantes da luta. Participar do MST permitiu assim um verdadeiro encontro com outros seres humanos, por meio de relações solidárias e não submetidas ao princípio do equivalente.

Assim, pode-se perceber que há realmente uma transformação na vida daqueles que participam do movimento social, e isso não tem somente a ver com o fato deles passarem a ter uma vida mais digna. Há uma mudança nas pessoas, que tiveram uma Experiência (Efahrung) ao entrarem para o MST, e depois disso, mesmo que "recuem na consciência", nunca mais voltarão a ser as mesmas. Cabe lembrar que mesmo o assentado que "rompe" com a liderança regional mantém a identidade de MST, de Sem-terra. O Movimento proporcionou e proporciona a novas pessoas, todos os dias, a possibilidade de identificação coletiva, de relação com o todo não reificada, de reflexão e de transformação, de Experiência (Erfahrung) e de aprendizagem (Bildung) com a consequente transformação interna.

Salientamos que esses assentados e a liderança do MST realmente construíram uma nova comunidade, um espaço bonito e rico, que como pontuamos anteriormente, mesmo com todas as contradições, continua lembrando para o entorno a possibilidade de superação desse modelo de sociedade, que somente reifica os indivíduos.

Há que se lembrar que se o mundo administrado registra a existência do assentado em sua diferença, e tende a absorvê-lo, instrumentalizando-o no sentido de reforçar o sistema, por outro lado, ele continua atuando contra o assentado, tendo em vista que sua existência também lembra a possibilidade de um mundo diferente e melhor, cuja mera possibilidade tem que ser banida da consciência pelo mundo administrado, que usa todas as suas armas nesse sentido, incluindo aí a indústria cultural. 
Dessa forma, a atuação do MST, no período do assentamento, também é essencial para continuar garantindo não só que os assentados se mantenham mobilizados e que se reproduzam dentro do sistema capitalista, evitando um novo êxodo rural, mas também contribuindo no avanço da consciência. Para continuar atuando no sentido de contribuir com a autonomia e a emancipação dos indivíduos, bem como com a construção de um outro mundo, o Movimento tem que problematizar diuturnamente as opções dos assentados e as suas próprias, ao invés de apresentar uma forma de organização ou de atuação como a única correta.

Uma postura que remeta à minoridade do indivíduo, ou que assuma, ainda que de forma velada, que o indivíduo não seja capaz de escolher e de tomar por vias próprias, através de um processo reflexivo, as rédeas de sua própria história em suas mãos, somente leva à reificação desse indivíduo.

Há que se observar que para os estudiosos que assumem uma postura mais conservadora, o grupo sempre se coloca instintivamente sob um chefe (ORTEGA Y GASSET, 2007; LE BON, 2005). Além disso, os participantes não têm capacidade para se autogerir, sendo necessária a presença de uma elite pensante que vai definir os caminhos e a direção que devem ser seguidos pelo grupo.

Segundo Ortega y Gasset, os indivíduos típicos das sociedades capitalistas, que ele vai chamar de "homem-massa", são pouco inteligentes, incapazes de terem idéias próprias e de saberem o que é melhor para si, são inertes e passivos, e por isso precisam ser guiados por aqueles que são mais capazes do que eles, uma minoria que é capaz de pensar pela massa, bem como de conduzir suas ações e definir seus objetivos.

O que leva os indivíduos a se unirem e os mantêm em um grupo é seu "instinto irreprimível de hierarquia" (ORTEGA Y GASSET, 2007, p. 274), sua necessidade de 
submeter-se a uma minoria que pode lhe mostrar qual o caminho correto. Dentro dessa visão de funcionamento de um grupo, a posição de autoridade e de obediência, bem como a minoridade do indivíduo são naturais à espécie humana, e os indivíduos sempre necessitarão de uma elite pensante para conduzi-los.

Nesse sentido, nossa análise se distingue radicalmente de uma análise conservadora do funcionamento do grupo, pois acredita na capacidade do indivíduo e dos coletivos de construírem seu caminho. Isso não implica em se fazer uma romantização do indivíduo, nem do assentamento e do movimento social: o indivíduo, em nossa sociedade, foi criado desde pequeno para a adaptação acrítica ao todo social, muitas vezes pedindo pela submissão e por relações heterônomas.

Assim, em nossa compreensão acerca do funcionamento dos grupos e dos indivíduos, a submissão a um líder ou autoridade externa não é algo natural, mas é decorrente da própria configuração social, que induz o desenvolvimento psíquico dos sujeitos em uma certa direção, àquela da adaptação e da formação de um ego fragmentado e de um superego externalizado, pronto a ser substituído por qualquer indivíduo ou idéia que tenham características especiais, que possam cumprir a função de substituir o ideal de ego enfraquecido dos indivíduos (ADORNO, 2006).

Segundo Freud, o que mantém os indivíduos unidos em um grupo são os vínculos libidinais que se formam entre os indivíduos, em função da ação de Eros e Ananke - o amor e a necessidade. Como vimos acima, com a mudança de acampamento para assentamento, as necessidades mudam consideravelmente.

Na época do acampamento, o MST não sofria riscos à sua reprodução no lugar de aglutinador e líder do grupo de acampados, pois havia um objetivo compartilhado entre os assentados, um inimigo comum, bem como a formação de laços libidinais entre os 
participantes, tendo-se em vista que o objetivo - a conquista da terra - era investido libidinalmente por todos os acampados.

Segundo uma interpretação freudiana, pode-se dizer que com a formação do assentamento, há indicativos de rompimento dos laços libidinais, com o retraimento da libido e reinvestimento no lote, na produção e na formação da nova comunidade. Além disso, a entrada da lógica do equivalente no assentamento acaba por contribuir com o rompimento dos vínculos libidinais que ligavam os indivíduos uns aos outros, bem como ligavam esses à liderança. Com isso, o indivíduo passaria a preocupar-se principalmente consigo mesmo. A tolerância para com as diferenças tende a decrescer, com a diminuição da limitação do narcisismo e da identificação entre os membros do grupo.

Assim, com o rompimento dos laços libidinais, os sentimentos negativos que eram dirigidos ao exogrupo (os inimigos da reforma agrária) passam a ser dirigidos também para os outros assentados, criando intolerância, desentendimentos, e dificuldade de compreensão e diálogo entre os assentados.

É bom lembrar que para Freud (1996), é possível a formação de vínculos libidinais entre aqueles que trabalham juntos. Assim, a participação em um grupo pode ser racional e positiva para os indivíduos e a sociedade, havendo uma possibilidade de acomodação entre as necessidades individuais e coletivas dentro de um grupo, com um equilíbrio na distribuição da catexia libidinal entre ambas.

Nesse sentido, segundo Freud, foi a criação de um grupo, o de irmãos, com regras de convivência e acordos mutuamente construído, que possibilitou o surgimento da civilização. Freud, como bom iluminista, confia no esclarecimento, na educação, e tem esperança no estabelecimento de um melhor equilíbrio na relação indivíduo/civilização. Os desencontros entre o indivíduo e seu meio social não se devem a uma disputa entre Eros e 
Tanatos, mas a uma questão de economia libidinal, de distribuição da libido entre ego e objetos, sendo reconciliável, portanto (FREUD, 1996, 1996b).

O fortalecimento de certas características do grupo, que Freud vai chamar de características individuais secundariamente adquiridas, faz com que aquele grupo contribua para o avanço da sociedade, em vez de representar uma regressão (FREUD, 1996). A formação de vínculos libidinais entre pessoas que trabalham juntas, para além do cumprimento da tarefa, para além do lucro imediato obtido com a colaboração, é o que dá condições para a formação de uma nova comunidade, como o assentamento.

A identificação também pode fortalecer o mundo interno do indivíduo, apontando para o fato de que uma relação com outros seres humanos pode ser enriquecedora, desde que não substitua o ideal de ego por algo externo, mas contribua com o processo de elaboração e de ampliação do mundo interno do indivíduo.

Por outro lado, na análise da existência de um grupo, não se podem colocar em segundo plano os determinantes sociais e materiais que levam à sua formação. Grupos como o MST não se formam devido a fatores psicológicos, mas a condições materiais e objetivas de existência, que impelem os indivíduos a se agruparem, em busca de melhores condições de existência (ADORNO, 2006; SIGAUD, 2005), sendo que os grupos se formam como decorrência de complexas questões econômicas, sociais e políticas (ADORNO, 2006). Em nosso entendimento, a participação em um grupo é um misto de elementos objetivos e subjetivos, racionais e irracionais, conscientes e inconscientes, esclarecidos e regressivos. Além do mais, os grupos são ambivalentes, porque constituídos dentro de uma sociedade ambivalente e contraditória. Nesse sentido, a participação no MST não é diferente. Como vimos acima, a contradição dessa sociedade acaba por se reproduzir no próprio Movimento. 
Os grupos podem se constituir como mecanismos de submissão dos indivíduos ao todo societário, mas também podem ser uma possibilidade de rompimento da alienação imposta aos indivíduos pelo capitalismo, se configurando como uma alternativa na direção da construção de uma sociedade mais justa e mais humana (HORKHEIMER; ADORNO, 1973).

Em nossa sociedade, a participação em um grupo apresenta características de ambivalência e regressão, seja na relação de um participante com outro, seja na relação destes com a liderança, bem como da liderança para com a base.

Esses elementos regressivos podem levar o grupo a um funcionamento heterônomo, e desembocam numa atrofia do indivíduo e de sua autonomia. Mesmo o movimento mais progressista, segundo Adorno (2006), pode acabar por reproduzir esses mecanismos alienados, quando se volta para a sua perpetuação a qualquer custo. Assim, o que muitos grupos de esquerda chamam de conscientização, na verdade não passaria de opressão, por se tratar de uma "liberdade imposta, e no terrorismo de uma prática conscientizadora baseada no pressuposto da minoridade psíquica dos governados" (ROUANET, 1985, p. $346)$.

Assim, participar de um grupo pode ser alienado ou não. É alienado quando os indivíduos estão enfraquecidos e abrem mão do seu ideal de ego, heteronomamente, e o seu superego é externalizado. Já o indivíduo que conseguir constituir seu ideal de ego pode resistir à sedução de deixar-se dissolver no grupo, no coletivo. Dessa forma, há grupos que fortalecem o indivíduo, e outros que o enfraquecem, ao diminuírem a força de seu ego (CROCHIK, 2007).

Nesse sentido, os grupos que não encaram os conflitos de frente contribuem para manter a alienação e a heteronomia dos seus participantes. No grupo, como em qualquer 
outro lugar, as contradições somente podem ser superadas se forem explicitadas: Adorno e Horkheimer, em consonância com a primeira tópica freudiana, vão postular que o que é inconsciente, deve se tornar consciente (ADORNO; HORKHEIMER, 1985). Somente a participação racional e livre em um grupo pode contribuir com o desenvolvimento da consciência do indivíduo, com que ele possa ser senhor do seu destino, mais crítico e menos submisso.

Contribuir com a formação verdadeira do indivíduo, incentivar sua autonomia e liberdade, valorizar o indivíduo e sua capacidade de reflexão como uma possibilidade de resistência e contraposição à dominação e homogeneização promovida pelo todo social é imprescindível para garantir que a participação em um grupo seja emancipadora e concorra para a transformação social.

Segundo a compreensão adorniana de homem, este último e sua subjetividade são constituídos a partir do social, mas não se resumem a isso: assim como é o único animal capaz de criar mais-valia a partir de seu trabalho, criar riqueza a partir do emprego de seu tempo, ele é capaz de criar "mais-existência" a partir da objetividade que o engendra. Nesse sentido, a esperança de transformação, nessa sociedade dominada pela totalidade, está no indivíduo. É necessário voltar-se para o indivíduo, explicitando os elementos que impedem a sua existência e a sua tomada de consciência, que o impedem de perceber e enfrentar aquilo que o nega (CROCHIK, 1996).

Não se trata, assim, de elogiar a individualidade como fim em si mesma, mas de recuperar, "em face da concórdia totalitária que apregoa imediatamente como sentido a eliminação da diferença, (...) algo da força social de libertação [que possivelmente] tenha-se retirado para a esfera individual" (ADORNO, 1992, p. 10). 
Assim, o caminho para a verdadeira consciência está em explicitar a fragmentação, que inevitavelmente vai ocorrer, em vez de contribuir para a romantização e, portanto, para um mascaramento da realidade. Em vez de tentar manter o coletivo e a solidariedade à força, estimular e proporcionar espaços de auto-reflexão, que propiciem participação política autônoma e verdadeira e que realmente estimulem a autodeterminação dos indivíduos, para que estes efetivamente possam se transformar em um novo homem e uma nova mulher (CROCHIK, 2007, MST, 2005, ROUANET, 1985).

O MST tem que aprender a lidar com as tensões dos novos espaços sociais que ajuda a constituir, contribuindo para fomentar espaços de discussão, problematizando as contradições em vez de tentar impor pacotes fechados de pensamento, tendo-se em vista que, de acordo com Arroyo (2004, p. 12), "os processos educativos vêm de dentro, não de fora. Vêm, sobretudo, das tensões sociais”. Segundo Adorno, é na tensão entre indivíduo e sociedade que se formam os grupos, bem como é na tensão entre a realidade e o desejo que é produzido o pensamento. Daí se depreende a importância das tensões no processo de formação dos indivíduos, bem como a necessidade de se compreender que a tensão entre o indivíduo e a sociedade é característica da relação entre ambos.

Para Adorno e Horkheimer, como a relação entre indivíduo e sociedade é constitutiva de ambos, o homem só poderá atingir uma existência plena e justa se a sociedade for justa e humana (HORKHEIMER; ADORNO, 1973). Assim, a luta pela transformação da sociedade tem que prosseguir, pois se a sociedade como um todo não for justa, o próprio desejo do indivíduo não vai ser.

Cabem ainda algumas considerações sobre a análise que Adorno faz do camponês e da reforma agrária. Quando o autor vai falar que o camponês é atrasado, ou foco de semicultura, necessitando de desbarbarização, cabe refletir que, da mesma forma que Marx, 
Adorno estava falando de um tipo específico de camponês, o camponês alemão da primeira metade do século XIX. Assim, com relação à reforma agrária e a re-ruralização a que Adorno se refere, cumpre perguntar também como se deu esse processo, se os camponeses que tiveram acesso àquela reforma agrária passaram por um movimento de luta pela terra, no qual questionaram sua posição de classe e romperam com a reificação desta sociedade. Segundo Adorno, o camponês semiculturalizado se caracteriza por ser aquele cuja autonomia e consciência não tiveram tempo de constituir-se, sendo que o sujeito passou de uma heteronomia cujo conteúdo era determinado pela tradição e pela religião, para uma heteronomia cujo conteúdo é dado pela indústria cultural (ADORNO, 1996).

Nesse sentido, cabe pontuar que o assentado, que participou do MST e da luta pela terra, não passou de uma heteronomia a outra, mas teve uma oportunidade ímpar de reconstruir sua subjetividade, ao mesmo tempo em que se constituía como sujeito coletivo, em uma sociedade que massifica a existência e homogeneíza as diferenças, bem como separa um indivíduo do outro.

O mesmo se aplica quando ele se refere ao fato de o camponês ser mais barbarizado que o habitante das cidades. No caso estudado, o camponês do qual estamos falando, é aquele que passou pelas cidades, tendo acesso à mesma educação e aos mesmos "bens culturais" que teve qualquer citadino das camadas mais baixas da população. Por outro lado, esse camponês viveu uma experiência de luta pela terra, que lhe permitiu questionar seu cotidiano reificado, bem como refletir sobre sua situação, sobre a dominação imposta pelo estado de coisas que é dado como natural.

Como já pontuamos, a participação no MST permitiu aos assentados quebrar a vivência e ter uma experiência, com a possibilidade de verdadeira formação que isso proporciona. Assim, no nosso entendimento, isso lhes deu uma oportunidade de formação 
cultural e de autonomia muito maior do que os que estão na cidade e que não passaram por experiência equivalente, certamente contribuindo para fazerem deles indivíduos mais autônomos e mais conscientes. 


\title{
5. Considerações finais
}

\author{
O duplo caráter da dialética: “A filosofia negativa, dissolução \\ universal, sempre dissolve também o próprio fator de \\ dissolução"
}

\section{Theodor Wiesegrund Adorno}

Este trabalho procurou, a partir de um enfoque crítico, entender os elementos condicionantes das relações estabelecidas entre os participantes de um movimento social de luta pela terra, em sua atuação concreta em um assentamento de reforma agrária, observando também o impacto dessas relações para os assentados e para o próprio movimento social.

Essas interações são observadas no momento em que assentados e lideranças do Movimento estão empenhados em constituir uma nova comunidade, em colocar em prática uma nova forma de organização da vida, ambos buscando transformar os seus sonhos em realidade - seja o sonho de viver com dignidade, seja o de construir um novo mundo.

Não pretendíamos com isso formular respostas definitivas, mas muito mais problematizar uma situação, buscando contribuir com o seu desvelamento, com o avanço da luta por uma sociedade mais justa e com a construção de relações que contribuam para a emancipação dos indivíduos e a transformação social.

Durante o desenvolvimento do trabalho, muitos aspectos da realidade observada não foram abordados, bem como muitos caminhos possíveis de análise não foram trilhados, em função do recorte de análise e da metodologia pela qual optamos. Entre as questões 
importantes que não foram suficientemente exploradas e aprofundadas podemos citar a "mística" e sua função subjetiva na aglutinação dos acampados/ assentados e como mobilizadora da luta; a história de vida pregressa, as diferenças individuais e o impacto destas na disponibilidade e na profundidade da experiência (Erfahrung) e da formação (Bildung) daqueles que passaram pela luta; a influência das questões de gênero na participação no movimento social; os elementos individuais que determinam uma propensão a participar da militância do MST, entre outros.

Neste estudo, o olhar sobre o assentamento partiu do princípio que estes são realidades sociais complexas, com suas contradições, seus conflitos, disputas e novas sínteses. Nesse sentido, como vimos, há uma idealização do assentamento, quando na verdade, da mesma forma como qualquer outro fenômeno social, ele não é homogêneo e isento de contradições, mas se configura como um território de disputas de modelos, mais do que um "território liberado". Há que se lembrar ainda que o assentamento, como novo espaço social, constitui-se a partir da tensão entre o desejo, o sonho e os modelos de organização da vida idealizados pelos assentados, e os modelos e desejos de outros atores que influenciam a configuração do assentamento, especialmente o Movimento e o INCRA. Na verdade, somente o fato de poder haver uma disputa nesse espaço, já caracteriza o assentamento como um avanço, tendo-se em vista que no mundo administrado, como os indivíduos já não conseguem mais refletir, não há sequer espaço para a ocorrência de conflitos, e há uma submissão total do sujeito e de sua subjetividade ao todo social, através de uma regressão auto-prescrita.

Nesse sentido, o Projeto de Desenvolvimento Sustentável/ Comuna da Terra Sepé Tiaraju é um espaço onde oitenta famílias estão reconstruindo sua vida e sua subjetividade, vivendo com dignidade e exercitando uma forma de viver e de se organizar que se 
contrapõem ao modelo homogêneo veiculado como única possibilidade pelos agentes do mundo administrado.

Assim, o MST representa a chance de dignidade e justiça social para milhares de brasileiros que são explorados e muitas vezes são submetidos a condições análogas à escravidão, à fome, à condição de coisa, de objeto. Dessa forma, a atuação do MST questiona a reificação desta sociedade, que para reproduzir-se anula a vida de vários seres humanos.

O Movimento também aponta para uma outra possibilidade, para uma sociedade mais justa onde ninguém passe fome e todos vivam com dignidade. Essa denúncia da promessa irrealizada de uma nova sociedade, por si só justifica a necessidade de fortalecimento desse movimento social.

Para além da contribuição objetiva com a mudança desta sociedade, ao questionar uma divisão desigual e injusta das riquezas socialmente produzidas, ao colaborar com a organização de uma grande massa da população que se encontra desorganizada, marginalizada e alijada de qualquer participação política, o MST também contribui com a mudança na vivência reificada desses indivíduos, com a transformação de sua subjetividade, com a possibilidade de experiência para esses sujeitos, quebrando a eterna repetição do sempre igual, com a adaptação ao sistema que anula o sujeito em suas diferenças e em sua autodeterminação.

Considerando que na nossa sociedade é raro formarem-se grupos que propiciem uma experiência de participação verdadeira, bem como possibilitem o fortalecimento da identidade, o MST propicia a esses sujeitos, mais do que a possibilidade de ter terra, uma possibilidade de reconstrução de sua subjetividade, de reflexão, de emancipação. 
Assim, a fragmentação dos espaços coletivos que se vê hoje no assentamento, a emergência de desentendimentos e de contradições entre liderança e base, no movimento social e dentro dos grupos de afinidade eram esperadas, ao olharmos o funcionamento dos indivíduos e dos grupos nessa sociedade administrada. Incomum é ter havido momentos no qual houve uma experiência coletiva, onde os indivíduos se colocaram de outra forma frente ao mundo administrado, momentos estes proporcionados pela participação no MST.

O inesperado não é que tenha havido fragmentação no período pós-assentamento, mas sim o ter havido um momento no qual essa fragmentação é suspensa por relações solidárias, não sujeitas à lógica da mercadoria, um momento no qual se criou uma identidade coletiva que perdura até hoje, embora de forma diferente. Os indivíduos que participaram da luta social não saíram dela os mesmos, mas foram modificados por ela, puderam questionar e romper com seu cotidiano reificado, criaram uma identidade e uma referência coletiva, na qual puderam ancorar sua percepção de mundo e suas reflexões. Há que se ponderar que a análise, restrita ao momento do assentamento, se depara mais com a vivência do que com a experiência. Caso a presente pesquisa tivesse se desenvolvido no período de acampamento, a experiência ganharia mais relevo.

Se, por um lado, o MST constitui uma possibilidade de vivência coletiva, de identificação e de solidariedade, pode acabar por solapar seu potencial emancipatório, se não atentar para os processos e contradições que ocorrem na prática do assentamento. Mesmo a experiência e a identificação com o coletivo, se baseadas em mecanismos narcisistas e irracionais, com a colocação de um único indivíduo no lugar do ideal de ego e a identificação narcísica dos indivíduos uns com os outros, pode contribuir para debilitar a autonomia do sujeito e sua própria subjetividade, em vez de ser uma prática conscientizadora. 
Temos ainda que lembrar que empenhar-se em mostrar que o assentamento dá certo, manter as famílias assentadas dentro desse sistema, apoiá-las em suas necessidades específicas, implica em contribuir para adaptá-las à lógica do equivalente, contraditória com os objetivos finais do Movimento. Como diria Adorno, a transformação plena só é possível com a transformação da sociedade como um todo, não adianta o MST e os próprios assentados acreditarem que conseguirão formar uma ilha de socialismo dentro do capitalismo, pois a própria sobrevivência das famílias assentadas, apoiada pelo Movimento, demanda um movimento de inserção dentro de uma lógica perversa.

Cabe salientar que se o MST quiser continuar contribuindo para a conscientização, para a emancipação e a autonomia dos sujeitos, bem como com a criação de uma sociedade mais justa, onde o indivíduo tenha assegurado o desenvolvimento de seu potencial, deve atentar para a importância da autodeterminação e da liberdade dos indivíduos, e resistir à tentação de tentar se perpetuar ou deixar que o fetiche da organização se sobreponha aos indivíduos, lutando contra toda e qualquer forma de reificação (HORKHEIMER; ADORNO, 1973).

A existência massificada não é inevitável, assim como também não o é a participação massificada em um grupo.

Nesse sentido, o MST pode fomentar a construção de espaços coletivos que contribuam com o esclarecimento, com a autonomia. Partir de onde estão os assentados, sendo um catalisador para o processo de discussão, de construção, de trabalho do pensamento, de reflexão, de aprendizagem, o que em grande medida significa deixar-se modificar por aquilo que se aprende.

Possibilitar a autonomia, a liberdade e a independência dos indivíduos que objetivamente já não podem ser livres, criar condições para a emergência do que está 
bloqueado pelo todo, olhar para o indivíduo como momento negativo dentro dessa sociedade administrada, talvez nos ajudem a caminhar em direção a um novo mundo, onde a subjetividade terá sentido e o trabalho será prazeroso como as férias (ADORNO, 1992).

O casamento/ harmonização entre os objetivos do indivíduo e os objetivos do grupo, que não está realizado nessa sociedade, não é impossível. Ele não só é esperado como é condição para uma humanidade livre, autônoma e realizada, seja para Freud, seja para Adorno. A nós nos resta lutarmos por essa nova sociedade, onde isso será possível.

Um dia, o mundo há de aparecer, sem mudanças quase, sob a luz incessante de seu dia feriado, quando não mais estiver sob a lei do trabalho e quando a quem torna à casa o dever for tão leve quanto o foi o jogo nas férias.

Theodor Wiesegrund Adorno 


\section{Bibliografia}

ABRAMAVOY, R. Transformações na vida camponesa: o sudoeste paranaense. Tese (doutorado), FFLCH-USP, São Paulo, 1981.

ADORNO, T.W. Teoria Freudiana e o padrão da propaganda fascista. Margem Esquerda, São Paulo, nº 7, p. 159-189, maio 2006.

. Teoria da Semicultura. Educação e Sociedade, São Paulo, no 56, p. 388-411, dezembro 1996.

O que significa elaborar o passado. In: Educação e emancipação. Rio de Janeiro: Paz e Terra, 1995.

. Educação - para quê? In: . Educação e emancipação. Rio de Janeiro: Paz e Terra, 1995b.

. Minima Moralia: reflexões a partir da vida danificada. São Paulo: Editora Ática, 1992.

. Educação pós-Auschwitz. In: COHN, G. Theodor W. Adorno. São Paulo: Editora Ática, 1986. 
Acerca de la relación entre sociología e psicología. In: JENSEN, H. (org.) Teoria critica del sujeto. Buenos Aires: Ed. Siglo XXI, 1986b.

. Capitalismo tardio ou sociedade industrial. In: COHN, G. Theodor W. Adorno. São Paulo: Editora Ática, 1986c.

. Crítica cultural e sociedade. In: COHN, G. Theodor W. Adorno. São Paulo: Editora Ática, 1986d.

Por que é difícil a nova música. In: COHN, G. Theodor W. Adorno. São Paulo: Editora Ática, 1986e.

A indústria cultural. In: COHN, G. Theodor W. Adorno. São Paulo: Editora Ática, 1986f.

Sobre a lógica das ciências sociais. In: COHN, G. Theodor W. Adorno. São Paulo: Editora Ática, 1986g.

e HORKHEIMER, M. Dialética do esclarecimento: fragmentos filosóficos. Rio de Janeiro: Jorge Zahar Editores, 1985.

, FRENKEL-BRUNSWIK, E., LEVINSON, D.J., SANFORD, R.N. La personalidad autoritária. Buenos Aires: Editorial Proyección, 1965. 
AMATUZZI, M. Experiência: um termo chave para a psicologia. Memorandum, Belo Horizonte/Ribeirão Preto, $\mathrm{n}^{\mathrm{o}}$ 13, p. 08-12, novembro 2007. Disponível em 〈www.fafich.ufmg.br/ memorandum/a13/amatuzzi05.pdf $\rangle.$ Acesso em: 10 out. 2008.

ANCA. O que levar em conta para a organização do assentamento: a discussão no acampamento. São Paulo: ANCA, 2002.

ARroyo, M.G. Prefácio. In: CALDART, R.S. Pedagogia do Movimento Sem Terra. São Paulo: Expressão Popular, 2004.

BALDUINO, D.T. Prefácio. In: STÉDILE, J.P. e FERNANDES, B.M. Brava Gente: a trajetória do MST e a luta pela terra no Brasil. São Paulo: Editora Fundação Perseu Abramo, 1999.

BENJAMIN. W. Experiência e pobreza. In: BENJAMIN. W. Obras escolhidas - vol. 1: magia e técnica, arte e política. Ensaios sobre literatura e história da cultura. São Paulo: Brasiliense, 1987.

BENJAMIN, W. Sobre alguns temas em Baudelaire. In: BENJAMIN, W., HORKHEIMER, M., ADORNO, T.W., HABERMAS, J.; Textos Escolhidos, coleção Os pensadores. São Paulo: Abril Cultural, 1983. 
BESSA, B.S. As experiências de Walter Benjamin. Morpheus, Rio de Janeiro, v. 5, $\mathrm{n}^{\circ}$ 9, 2006. Disponível em: 〈www.unirio.br/morpheusonline〉 Acesso em: 15 mar. 2007.

BOGO, A. A vez dos valores. São Paulo: MST, 1998. (Cartilha de Formação nº 26).

BRENNEISEIN, E. Relações de poder, dominação e resistência: o MST e os assentamentos rurais. Cascavel: Edunioeste, 2002.

BRENNEISEIN, E. Assentamentos rurais: estabelecendo um diálogo entre duas perspectivas de análise. In: FRANÇA, C.G. e SPAVOREK, G. Assentamentos em debate. Brasília: MDA/NEAD, 2005.

BURILLO, F.J. Prologo a la edición española. Em: LE BON, G. Psicología de las masas. Madrid: Ediciones Morata, 2005.

CALDART, R.S. Pedagogia do Movimento Sem Terra. São Paulo: Expressão Popular, 2004.

CALDART, R.S. e KOLLING, E.J. O MST e a educação. In: STÉDILE, J.P. A reforma agrária e a luta do MST. Petrópolis: Editora Vozes, 1997.

CAMARANO, A.A. e ABRAMOVOY, R. Êxodo rural, envelhecimento e masculinização no Brasil. Revista Brasileira de Estudos Populacionais, Campinas, v. 15, nº 2, p. 45 $65,1998$. 
CANETTI, E. Massa e Poder. São Paulo: Companhia das Letras, 2005.

CÂNDIDO, A. Os parceiros do Rio Bonito. São Paulo: Livraria Duas Cidades, 1987.

CARONE, I. Teoria Crítica e pesquisa empírica na psicologia. Psicologia e Sociedade, Porto Alegre, v. 13, n², p. 9-17, jul/dez 2001.

CAUME, D. J. A tessitura do "assentamento de reforma agrária": discursos e práticas instituintes de um espaço agenciado pelo poder. Tese (doutorado), IFCH- UNICAMP, Campinas, 2002.

COHN, G. Theodor W. Adorno. Introdução: Adorno e a Teoria Crítica da Sociedade. São Paulo: Ática, 1986.

COLETTI, C. Avanços e impasses do MST e da luta pela terra no Brasil nos anos recentes. In: SEOANE, J. Movimientos sociales y conflicto en America Latina. Buenos Aires: CLACSO, 2003.

COLOMBO, E.R. Prologo a la edición en castellano. In: ADORNO, T.W., FRENKELBRUNSWIK, E., LEVINSON, D.J., SANFORD, R.N. La personalidad autoritária. Buenos Aires: Editorial Proyección, 1965. 
CONCRAB, Novas formas de assentamentos de reforma agrária: a experiência da Comuna da Terra. Brasília, CONCRAB/INCRA/CRT, 2004. (Cadernos de cooperação agrícola $\left.n^{\circ} 15\right)$.

COSTA, B.C.G. Dialética do Esclarecimento: a sociedade da sensação e da (des)informação. In: ZUIN, A.A.S.; PUCCI, B.; RAMOS-de-OLIVEIRA, N. (orgs.) Ensaios Frankfurtianos. São Paulo, Cortez Editora, 2004.

CROCHIK, J.L. Teoria Crítica e formação do indivíduo. São Paulo, Editora Casa do Psicólogo, 2007.

CROCHIK, J.L. Os desafios atuais no estudo da subjetividade na psicologia. Psicologia USP, São Paulo, v. 9, nº 2, p. 69-85, 1998.

CROCHIK, J.L. Notas sobre a psicologia social de T.W. Adorno. Psicologia e Sociedade, Porto Alegre, v. 8, n 1, p. 43-62, jan/jul 1996.

D’INCAO, M.C. Assentamentos Rurais do Estado de São Paulo: notas sobre os impasses da assessoria técnica estadual. In: ITESP, Cultivando Sonhos: caminhos para a assistência técnica na reforma agrária. São Paulo: ITESP, 2000. (Cadernos ITESP n ${ }^{\circ}$ 7).

D'INCAO, M. C. O MST e a verdadeira democracia. In: STÉDILE, J.P. A reforma agrária e a luta do MST. Petrópolis: Editora Vozes, 1997. 
D’INCAO, M.C.; ROY, G. Nós, cidadãos: aprendendo e ensinando a democracia. Rio de Janeiro: Editora Paz e Terra, 1995.

FERNANDES, B.M. Formação, Espacialização e Territorialização do MST. In: STÉDILE, J.P. A reforma agrária e a luta do MST. Petrópolis: Editora Vozes, 1997.

FERNANDES, B.M. MST: formação e territorialização. São Paulo: Hucitec, 1996.

FOLHA DE SÃO PAULO, Bolsa Família esvazia o MST, dizem especialistas. Jornal Folha de São Paulo, São Paulo, 04 nov. 2007,Caderno Brasil, p. 4-6, p. 9-10.

FOLHA DE SÃO PAULO, Cortadores de Cana têm vida útil de escravo em São Paulo. Jornal Folha de São Paulo, São Paulo, 29 abr. 2007, Caderno Dinheiro.

FREI BETO. Sem Terra e Cidadania. In: STÉDILE, J.P. A reforma agrária e a luta do MST. Petrópolis: Editora Vozes, 1997.

FREUD, S. Psicologia de grupo e análise do ego. Rio de Janeiro: Imago, 1996. (Edição standard brasileira das obras completas de Sigmund Freud, volume XVIII).

FREUD. S. O mal-estar na civilização. Rio de Janeiro: Imago, 1996b. (Edição standard brasileira das obras completas de Sigmund Freud, volume XXI). 
GAGNEBIN, J.M. Pesquisa empírica da subjetividade e subjetividade da pesquisa empírica. Psicologia e sociedade, Porto Alegre, v. 13, n 2, p. 49-57, jul-dez 2001.

GOHN, M.G.M. Os Sem-terra, ONG's e cidadania. São Paulo: Cortez Editora, 2000.

GOHN, M.G.M. Teoria dos Movimentos sociais: paradigmas clássicos e contemporâneos. São Paulo: Edições Loyola, 1997.

GRAZIANO, F. O Recado do campo. O Estado de São Paulo, São Paulo, 24 out. 2006.

GRAZIANO, F. Qual reforma agrária: terra, pobreza e cidadania. São Paulo: Geração editorial, 1996.

HORKHEIMER, M. e ADORNO, T. W. Temas básicos de sociologia. São Paulo: Cultrix/Edusp, 1973.

INCRA, Instrução especial no 50, Brasília: mimeo, 26 agosto 1997.

LASTORIA, L.A.C.N. O topos psicológico no interior da teoria crítica da sociedade. In : Ensaios Frankfurtianos. São Paulo: Cortez Editora, 2004.

LE BON, G. Psicología de las masas. Madrid: Ediciones Morata, 2005. 
LEITE, F.L.; DIMENSTEIN, M. Subjetividade em movimento: o MST no Rio Grande do Norte. Psicologia e Sociedade, Porto Alegre, v. 18 nº 1, jan/abr 2006.

LEITE, S.; HEREDIA, B.; MEDEIROS, L.; PALMEIRA, M.; CINTRÃO, R. Impacto dos assentamentos: um estudo sobre o meio rural brasileiro. Brasília/São Paulo: NEAD/EdUnesp, 2004. (Coleção Estudos NEAD nº 6).

LEITE, S. Assentamentos rurais no Brasil: impactos, dimensões e significados. In: STÉDILE, J.P. A reforma agrária e a luta do MST. Petrópolis: RJ, Vozes, 1997.

LEOPOLDO E SILVA, F. Conhecimento e razão instrumental. Psicologia USP, São Paulo, no 8, vol. 1, p. 11-31, 1997.

LUDKE, M. e ANDRÉ, M.E.D. Pesquisa em educação: abordagens qualitativas. São Paulo: EPU, 2003.

MAAR, W. L. À guisa de introdução: Adorno e a experiência formativa. In: ADORNO, T.W. Educação e emancipação. Rio de Janeiro: Paz e Terra, 1995.

MARCUSE, H. A ideologia da sociedade industrial: o homem unidimensional. Rio de Janeiro: Zahar, 1982.

MARTINS, J.S. O sujeito oculto da reforma agrária. Porto Alegre: UFRGS, 2003. 
MARTINS, J.S. Reforma agrária: o impossível diálogo. São Paulo: Edusp, 2000.

MARTINS, J.S. A questão agrária brasileira e o papel do MST. In: STÉDILE, J.P. A reforma agrária e a luta do MST. Petrópolis: Vozes, 1997.

MARTINS, J. S. Os camponeses e a política no Brasil. Petrópolis: Vozes, 1995.

MARTINS, J.S. O poder do atraso: ensaios de sociologia da história lenta. São Paulo: Hucitec, 1994.

MARX, K. O 18 Brumário de Luís Bonaparte. São Paulo: Abril Cultural, 1978. (Coleção Os Pensadores).

MDA. Estatísticas do meio rural. Brasília/São Paulo: MDA/DIEESE, 2006.

MDA. Balanço MDA - 2003/2006: desenvolvimento agrário como estratégia. Porto Alegre: NEAD, 2006b.

MDA. Metodologia para implantação dos projetos de desenvolvimento sustentável PDS. Brasília: MDA, 2000.

MEDEIROS, L. S. Reforma Agrária no Brasil: história e atualidade da luta pela terra. São Paulo: Fundação Perseu Abramo, 2003. 
MEDEIROS, L. S. Impactos históricos do uso e da propriedade de terra no Brasil. In: STÉDILE, J.P. A reforma agrária e a luta do MST. Petrópolis, RJ, Vozes, 1997.

MIRANDA, M. E. Análise de uma situação de conflito entre os assentados e o MST. Dissertação (mestrado), FFLCH, São Paulo, 1999.

MOURA, M.M. Liberdade e igualdade: reflexões sobre campesinato sertanejo e política. Cadernos CERU, São Paulo, nº 3, v. 2, p. 7-32, 1991.

MST. Vinte e cinco anos do MST. Revista Sem Terra. In: 〈www.mst.org.br/mst/pagina.php?cd=6279〉, 2009. Acesso em: 05 abr. 2009.

MST. Da Califórnia à realidade: o agronegócio em Ribeirão Preto, Vídeo, Disponível em: 〈http://esp.powos.org/Send-Modify/Da-California-a-realidade-O-Agronegocioem-Ribeirao-Preto2>, 2008. Acesso em: 23 mar. 2008.

MST. Carta do V Congresso Nacional do MST. Brasília, junho de 2007. Disponível em: 〈www.mst.org.br/mst/pagina.php?cd=3713〉. Acesso em: 17 mar. 2008.

MST. Dossiê MST escola. São Paulo: Editora Expressão Popular, 2005.

MST. Quem Somos. Disponível em: 〈www.mst.org.br/historico〉 Acesso em: 08 nov. 2004. 
MST. Idéias para um novo modelo de reforma agrária: Comuna da terra. São Paulo: mimeo, 2001.

NAVARRO, Z. "Mobilização sem emancipação" - as lutas sociais dos sem-terra no Brasil. In: SANTOS, B.S. (org) Produzir para viver. Rio de Janeiro, Civilização Brasileira, 2002.

ORTEGA Y GASSET, J. A rebelião das massas. São Paulo: Martins Fontes, 2007.

PETRAS, J. Os camponeses: uma nova força revolucionária na América Latina. In: STÉDILE, J.P. A reforma agrária e a luta do MST. Petrópolis: Editora Vozes, 1997.

POKER, J. G. A. B. Prática de vida e os desencontros da libertação. Dissertação (mestrado), FFLCH, São Paulo, 1994.

POLETTO, I. A terra e a vida em tempos neoliberais: uma releitura da história da CPT. In: CPT. A luta pela terra. São Paulo: Editora Paulus, 1997.

REVISTA VEJA, O manual da Guerrilha. Revista Veja, São Paulo, edição 2097, ano 42, $\mathrm{n}^{\circ}$ 4, p. 46-50, 28 de janeiro de 2009. 
ROS, C.A. O MST, as instâncias do Estado para tratamento da questão agrária e a constituição de assentamentos rurais. In: MOREIRA, R.J. Identidades sociais: ruralidades no Brasil contemporâneo. Rio de Janeiro: DP\&A, 2005.

ROUANET, S. P. Teoria Crítica e psicanálise. Rio de Janeiro: Tempo Brasileiro, 1986.

ROUANET, S. P. A razão cativa. As ilusões da consciência: de Platão a Freud. São Paulo: Brasiliense, 1985.

RSJDH (Rede Social de Justiça e Direitos Humanos). A falência do Programa de Crédito Fundiário do Banco Mundial. São Paulo: RSJDH, 2004.

SAUER, S. O significado dos assentamentos de reforma agrária no Brasil. In: FRANÇA, C.G. e SPAVOREK, G. Assentamentos em debate. Brasília: MDA/NEAD, 2005.

SEADE (Fundação Sistema Estadual de Análise de Dados). Índice Paulista de Responsabilidade Social - Região Administrativa de Ribeirão Preto. São Paulo, SEADE, 2002. Disponível em: 〈www.seade.gov.br/produtos/iprs/analises/RARibPreto.pdf $\rangle.$ Acesso em: 17 jan. 2009.

SCHREINER, D.F. Entre a exclusão e a utopia: um estudo sobre os processos de organização da vida cotidiana nos assentamentos rurais. Tese (doutorado), FFLCHUSP, São Paulo, 2002. 
SCOPINHO, R.A.; OLIVEIRA, D.R.; RESENDE, J.R.; SANTOS, J.A. O processo organizativo do assentamento Sepé Tiaraju: novos ânimos no cenário dos movimentos sociais na região de Ribeirão Preto. Reforma Agrária, Revista da ABRA, São Paulo, v. 34, n 1, p. 149-176, jan-jun 2007.

SIGAUD, L. As condições de possibilidades de ocupação de terra. Tempo Social: revista de sociologia da USP, São Paulo, v. 17, n 1, p. 255-280, 2005.

SILVA, M.A.M. A luta pela terra: experiência e memória. São Paulo: EdUnesp, 2004.

SPAVOREK, G. A qualidade dos assentamentos da reforma agrária brasileira. São Paulo: Páginas e Letras, 2003.

STÉDILE, J.P. A reforma agrária e a luta do MST. Petrópolis: Vozes, 1997.

STÉDILE, J.P. e FERNANDES, B.M. Brava Gente: a trajetória do MST e a luta pela terra no Brasil. São Paulo: Editora Fundação Perseu Abramo, 1999.

TURATTI, M.C.M. Os filhos da lona preta. São Paulo: Editora Alameda, 2005.

VASQUEZ, A.P. Agricultores, companheiros, irmãos: estudo sobre cultura e religião entre os assentados de Sumaré I. Dissertação (mestrado), FFLCH, São Paulo, 2001. 
VAZ, A.F. Corpo e indústria cultural: notas para pensar a educação na sociedade contemporânea. In: ZUIN, A.A.S.; PUCCI, B.; RAMOS-de-OLIVEIRA, N. (orgs.) Ensaios Frankfurtianos. São Paulo: Cortez Editora, 2004.

ZIMMERMANN, N.C. Os desafios da organização interna de um assentamento rural. In: MEDEIROS, L.S. (org) Assentamentos rurais: uma visão multidisciplinar. São Paulo: UNESP, 1994.

ZUIN, A.A.S., PUCCI, B. e RAMOS-de-OLIVEIRA, N. Ensaios Frankfurtianos. São Paulo: Cortez Editora, 2004.

ZUIN, A.A.S., PUCCI, B. e RAMOS-de-OLIVEIRA, N. Adorno: o poder educativo do pensamento crítico. Petrópolis: Vozes, 1999. 
1- Mapa do Sepé 
2- Planta das casas 
3- Foto do protesto no jornal 